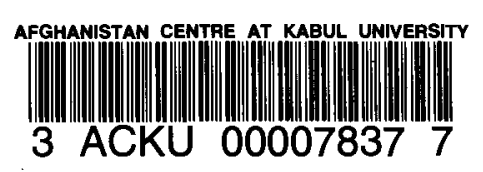

\title{
ACBAR
}

\section{Compilation of the}

\author{
VETERINARY
}

Sub-committee documentation

\section{9}

to

1994

Agency Coordinating Body for Afghan Relief

2 Rehman Baba Road

U.P.O Box 1084

University Town

Peshawar,NWFP

Pakistan

TEL: 091 44392/40471

FAX:091-91-840471

EMAIL: acbaar@radio.psh.net.pk

\section{Volume I}

March 1999 


\begin{tabular}{|c|c|c|}
\hline Section: & Contents: & Pages(S) \\
\hline 1994 & January-November 1994 Minutes & $1-44$ \\
\hline 1993 & January-December 1993 Minutes & $1-46$ \\
\hline 1992 & $\begin{array}{l}\text { January- December } 1992 \text { Minutes } \\
\text { CRAA Field Mission Report Nangarhar Province } \\
\text { UNDP Vaccination Procedure - Enterctoxaemia }\end{array}$ & $\begin{array}{l}1-62 \\
63-78 \\
79-82\end{array}$ \\
\hline 1991 & $\begin{array}{l}\text { January-December } 1991 \text { Minutes } \\
\text { DCA-Report }\end{array}$ & $\begin{array}{l}1-56 \\
57-60\end{array}$ \\
\hline 1990 & $\begin{array}{l}\text { January- October } 1990 \text { Minutes } \\
\text { SCA } \\
\text { Medicine Charge by DCA (VFV) } \\
\text { Livestock and Veterinary Services } \\
\text { MADERA Policy and charging Veterinary Medicines } \\
\text { Contagious Caprine Pleuropaeumonia (CCPP) } \\
\text { Report of Field Visit to Achin and Rodat Districts Nangarhar } \\
\text { Province from April 14-17 } \\
\text { Endemic Diseases in Jeghatu Wardak } \\
\text { UNDP }\end{array}$ & $\begin{array}{l}1-14 \\
15-16 \\
17-18 \\
19-20 \\
21-24 \\
25-26 \\
27-30 \\
\\
31-32 \\
33-36\end{array}$ \\
\hline 1989 & $\begin{array}{l}\text { October-November } 1989 \\
\text { GAF Veterinary Project }\end{array}$ & $\begin{array}{l}1-14 \\
15-16\end{array}$ \\
\hline
\end{tabular}




\section{A C: B A F \\ VETEFINAFY SUE-COMMITTEE

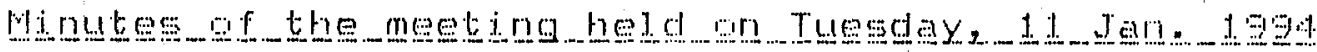

I. Approval of the agenda:

Approved.

I. . Minutes of the previgus meeting:

The Minutes were approved.

I I . Discussign on procurement of medieine:

Frourement of medicines from alternate sources other than the wese currently monopolizing the marlet was discussed. UNDF sad about two years ago they have contated pharmentical rompanies in Australia, Sweden, Holland and Fngland. Two monthe after the initial contact, the price li st containing the information for wny 2 of the medianes used for our program come from Austral a, and for G brands of medicines from England. The members suggested that the possibility for the procurement of medicines and vaceines should be deplored by either IJNDF/OFG or FAO.

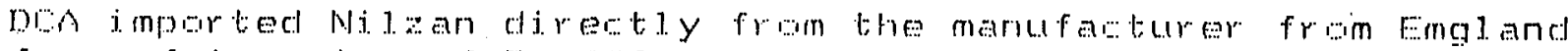

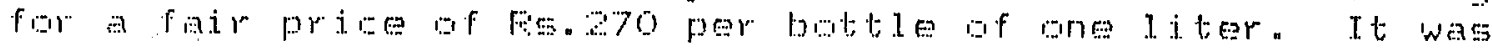
mentioned that the possibity of prucuring Nilzan for NGOS throgh Don has to be dis

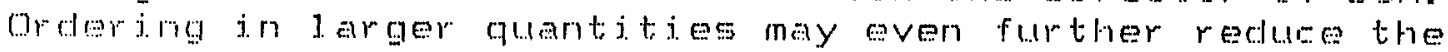
shipment ast;

It was emphasized by the representatives af ald the blos thet instruments of reliable qual ity is an asset to the clinis, the j.nstruments gurrently supplied to the wijnics br the bnes available in the in the martel; are of the poor quality, though

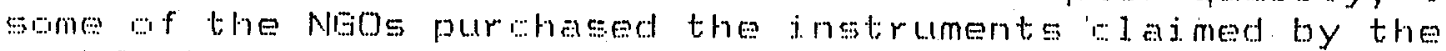
manifinturers as the export glatity. Howevery it was requested by the NGOS that UNDFYOFS ar FAO should help to souve this problem.

IV. Trainjog solrse:

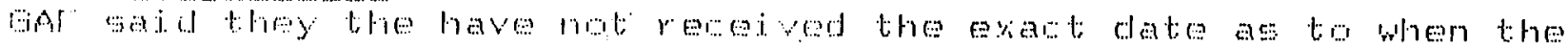
guest professor invited for the field gtaff refresher warese will

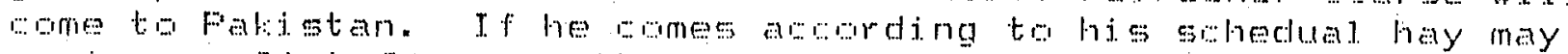

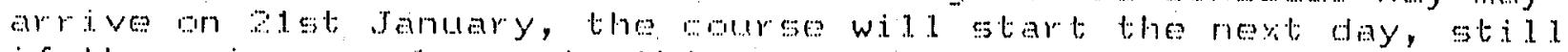
if there is any wange to this dato or otherwise the NeOs wi.l. be i. nf brmed i mmediately.

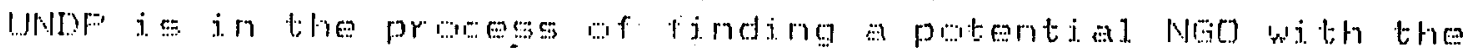
teohni a a apability to provide a business managenent training

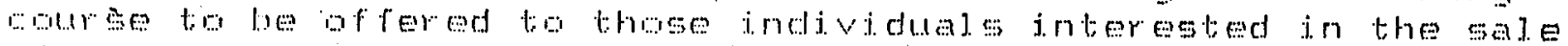
of veterinary medicines as a private business. The

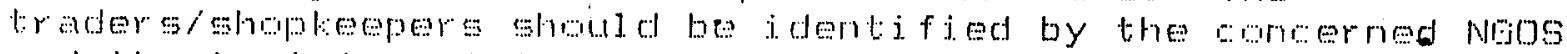

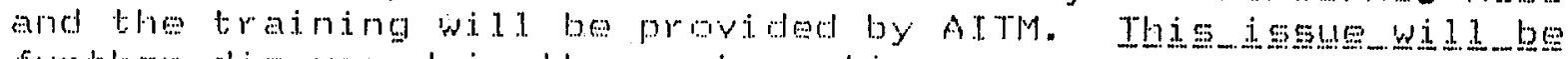

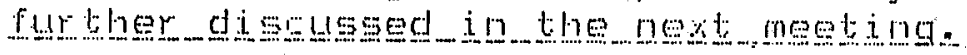




\section{Any gther business:}

A) Wostrution af veterinary oliniss was onge again rajged in

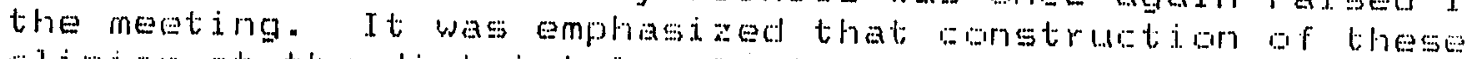

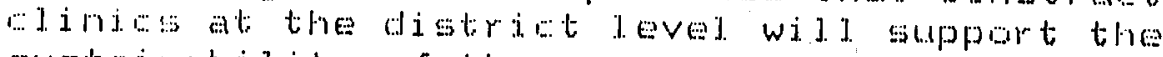
sustainability of the program within the comtiry. Funding

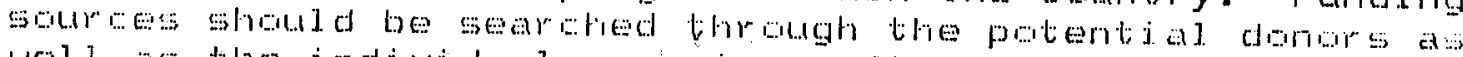
well as the individual agene $i$ es. It was said that the

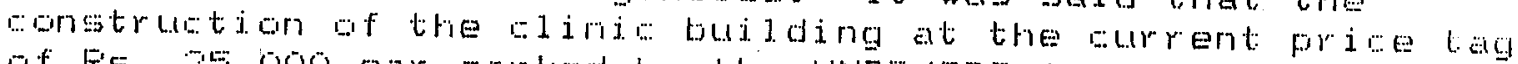
of Fe. 25,000 ear martsed by the UNDF/OFS is not sufficter, NGOS reguested the worsideration ar an amendment to the

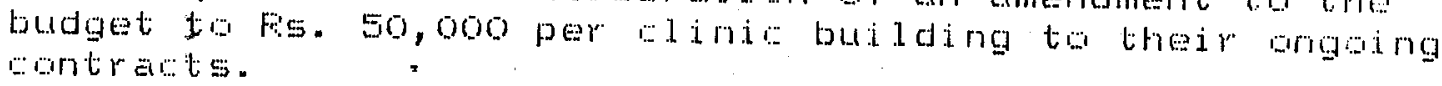

B) Based wr the repeated reguests from the farmers inside Afglonistan for the provision of improved breeding progran for livestoul, it was slogested if the NGOS a an help in this

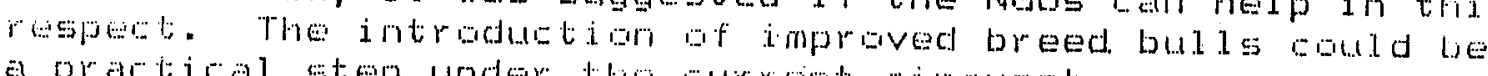

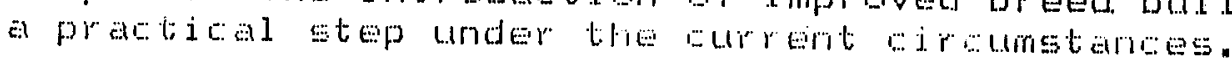

For the sates of cooperation and effertive coordination it

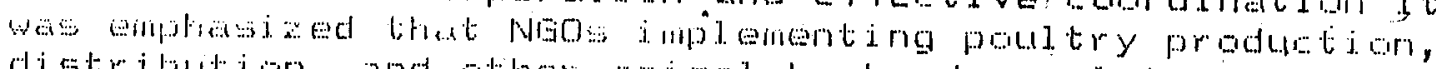
distributibn, and other animal hesbandry related projects should attiend wn a reguj ar bases the Veterinary Subarmioit tee meetings. The cowperation af the respested domors

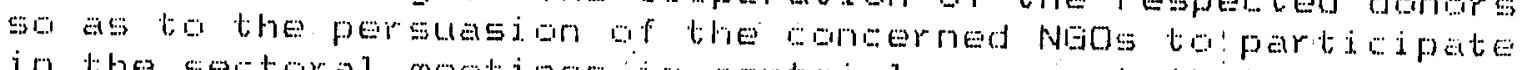
in the set toral meetings is aertainly a contributing
factor.

a. DEA and BAF has resolved the issue af averlapping af a El ini in Maddanstiar. Dod had the presence in a vil lage under the jur isdiation of la danshar administrative urit

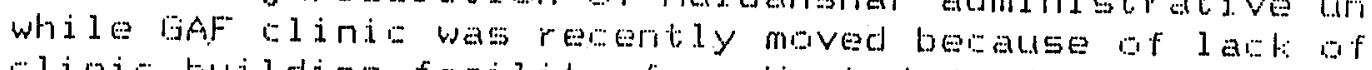

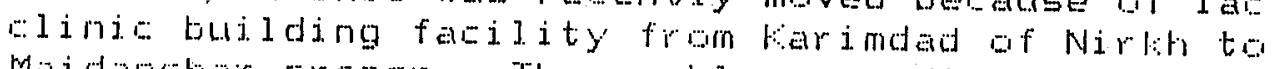
Maidanshar proper. The pioblem was discused, GAF agreed

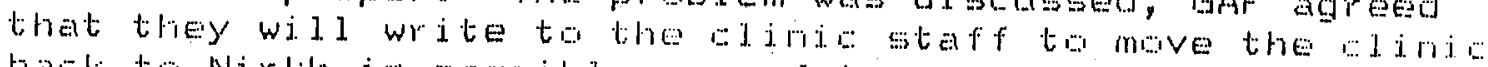
bast: to Nirlit in possible rear future.

\section{Ine attendants:}

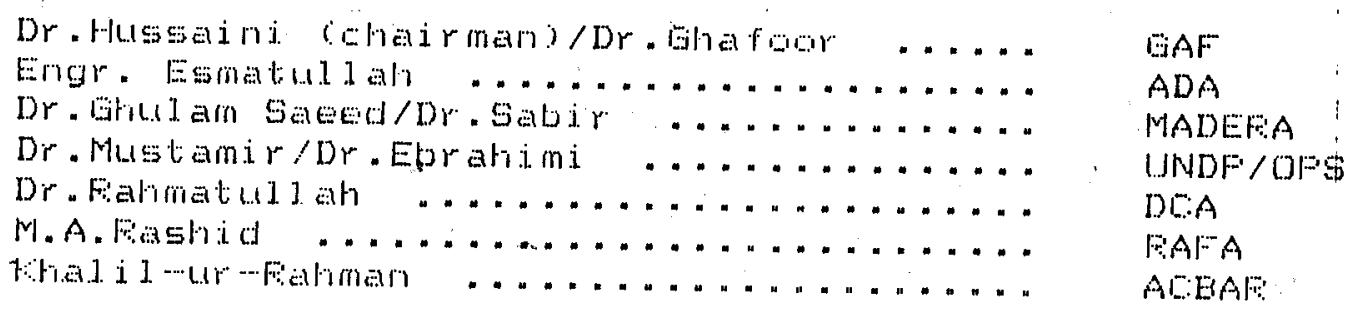


I. Noproyud of lihe netenda

'lio agenda was spproved.

II. Minulde_of tha_previous_meeting

There was orly a snall typjug mjstake. The rest of the minules were approved.

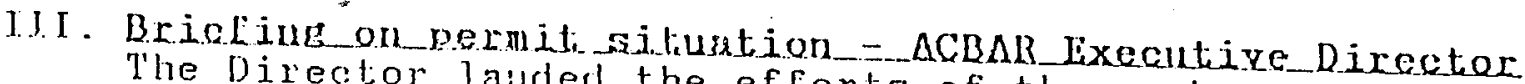
The Director lauded the efforts of the members of the Veterinary sub-committee gnd stated thot this committee is one of the imrortant Sectoral Coordination Groups. The of interest and him. Ile requested orn rajse matters directly with at. tend line meetings.

Regurdjng the issue of pexmits which was a matter of general. concern, the Director said that the situstion is not clesr Is lamabad that the problem by hie Chief Conimissjoner in requested the agencies tom of permits would be resolved. He both issued and those that hend copies of permits requested, will. collect the information have not been issued yet. He try his best to persuade thon up until 10 February and will workable system in place.

lle further said that he will. try to persuade the UN and the diplomatic community including the Afghan Ambassadorito
Pali istan, to help jn resolving this problem.

Srimo of the agencies; also expressed their concern in ronnection to the jssumes of permits of commoditios to be Lranspoted orly lhrough, Torklum ond Ghulam Khan Kilay.
l'he Direotor promised to discuss this matter with the Chief
Commjosioner as well Commissioner as well. It was promised that members would be
informed of the result.s.

Dne of the agencies expressed their unhappiness over the way of behavior by the authorities respansible for permit issiance and added that the rrocess of permit was not good.

Dis repolted that. they are waiting for permits for 40 days and have not received lhe permils yet. The Director aslied them to erovide him with the copies of permit requept.

(iAF reported that the problem of permit was solved and they recoived permits for lhoir velerinary medicine from

Is lamabod and for their vehicles from peshawar: 
Concern on border crossing of national staff of NGOs was also expressed. The Director clarified that ACBAR has sent a memo to its members to obtain lists of names as well as other necessary information on their staff who cross the border regularly. As soon as enough information is collected, it will be then forwarded to the Commissioner for Afghan Refugees - NWEP, who had promised to follow up the matter. So far 28 agencies had replied to the memo.

The Director said that one agency, that had listed the names of their staff as well as the registration number of their vehicle under the letterhead of their organization introducing them to the authorities at the border had been allowed to cross. The staff as well as the veticle of the agency crossed the border without any problems. Since there is crowed of people after $9: 00$ am, it was recommerided that border should be reached before $9: 00$ am.

IV. Announcenents

DCA had produced a calendar for the year 1994, which could also be used for veterinary extension purposes. 1 to 99 copies could be obtained for Rs. 25 per copy. For more than 99 copies the cost reduces to $\mathrm{Rs} .20$ per copy.

The agency will start its 11 th paravet course in late April. The application form and details of the course is attached.

The application forms should be returred by 1 March 1994 arid the sfudents should come to DCA on 16 April.

On 22 Harch, DCA will start a one-week Epidemiology course. The number of participants will be limited (maximum $7-8$ persons). The participants should have krowledged of computer (Lotus) and statistics. Interested NGOs stiould inform DCA in two days.

GAF has printed two books in Dari language: 1) Hicro Computer and 2) Business Accounting. The boolis could be obtained from ACBAR's Library/GAF for Rs. 40 and 85 respectively.

v. Any other business

MADERA had a mission to Laghman and Kunsr province in January to evaluate the agency's veterinary programs. It was reported that people in llangalam were complaining that anti-biotic, specially, Terramycin LA and Oxytetracycline purchased from the local shops nere nor-effective. It was noticed that local shopkeepers had sold the expired medicines. People were ready to buy medicine from the HGOs even.with a higher price. It was said that some BVWs are selling medicines on shopkeepers.

UNDP said that they are well aware of the problem and suggested that a way of solution should be sought. To reduce selling of the medicine by the $1 \mathrm{GO}$ staff to the local 
shops, it was suggested that veterinarians should be provided with the required selected quantity of the medicine (not more than the need).

Insurance of the field staff who are working under difficult cj.rcumstances inside the country should be considered and a common policy should be adopted in this connection. It was suggested that this points should be included in the agenda for the next Veterinary Sub-committee meeting which will be
held on 8 March 1994 .

It was also suggested that construction of veterinary clinics should be carried out through a standard design. GAF said that they have already designed a clinic which could be considered by the members. This item will be also discussed in the next meeting:

ACBAR reported that they would like to produce a map which could indicate veterinary activities all over Afghahistan. It was requested to the agencies to provide up to date information and cooperate by providing details as to the exact location of the projects. The members promised to cooperate as much as possible. Further discussion on this will be followed in the next meeting.

The participants:

- Dr. M. llalimi (ChaIRMAN)

- Abduluah

- Kazim

- Dr. Ghulam Saeed

- M. A. Rashid

- Sayed Mohammad

- M. Zia

- Shafique

- Dr. Bashir Ahmad

- Dr. A. A. Nasseri

- Dr. Ghafoor Khan

- Q. Fazil Rabi

- Charles MacFadden

- Sayed Hohammad

- Shafiq Ahmad

DCA

$\triangle \mathrm{RDA}$

PRB

MADERA

RAFA

?

CRAA

CRAA

CRAA

UHDP

GAF

$G \triangle F$

$\triangle C B A R$

$A C B A R$

ACBAR

$$
\begin{aligned}
& \text { - Mary Fotwards afo Maris } \\
& \text { - Don Meyer } \\
& \text { - smapre } \\
& \text { ntif- Am }
\end{aligned}
$$

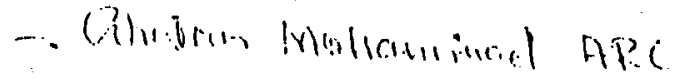

$$
\begin{aligned}
& \text { - Asif Proshid Rora }
\end{aligned}
$$




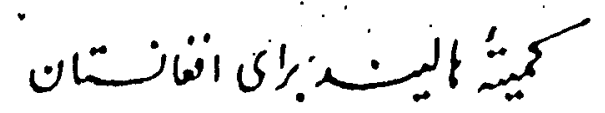

$\triangle P P L I C A I I O H \quad E O R \quad P A R \triangle Y E I \quad C O U B S E S$

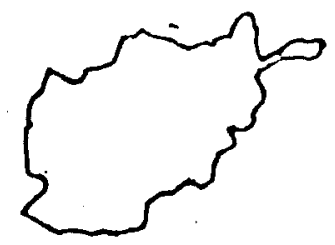

ncs started its first paravel course in 1986. Since then almost 200 paravets were trained.

For the paravet courses IXCA will provide:

- 5 months theoretical and [ractica]. training in preventive and curative veterinary work,

- loorl and lodging, as well as some pocket money,

- manuals ard other essential course materials.

Golititiontis

The orjeria for participation in a pravet crurse are outined below.

'lk: parl:ic: ipant: will :

- have an interest in voterinary work,

- Le: able to read and write rither [erejom or: loshto wel],

-. have (preferably) 12th Elerde eduration,

- Fass the entronce test,

- wj.l1 show good progress rluring lihe rourso *).

- have a Eoral reputation in his sica.,

- return to his village after completion of the course.

The sonding N(S) will:

- provide the candidate with a letter of introduction with 2 ptiotos attarherd. which are signed by the No,

- emeloy the jntroduced cardidate alter comeletion of the trajuing, emeloy the paravel in his own villans,

-. lill out the arwlicalion lorm. (in case of an unforseen constraint, in the budgel, DCA may request i,he serding NGO to pay for frodrosts and training materials for the candidate)

The maximum number of participants will be 25 per course.

When required DCA con provjde nedicines and erquipment to the farticipants" aller completion of the comrse. Pleasc conlact DCA well in advance to discuss the eonditions.

*) Aeroximately 6 weeks after the beginning of the course all students will be evaluated. Despite the fact that some students appear to be weak in the entirance examination, they are of ten gjven a chance to prove themselves during the rjest weeks of the course; but when they do not show good progress they will not be allowed to continue the course. However, such a decision will only be taken afler careful consjderation by the tem of traincrs. Please note that careful selection of the candidates will. jncrease thejr chances of completing the course succesfully.

Posiol nddress

lliniversily Post Orlice
Telephone

10571,191731
$\operatorname{Fax}$

$052 / 310258$

0.521
Bónk

Grindlays Bank Peshawar 
names appidiront :

Eather:s name :

vi.1.1กge

district

Eunvinge:

jritended polace of fulure employmert:

nome aryl iront, :

lint:trest a mans: :

vilu.gs?

dicilingt:

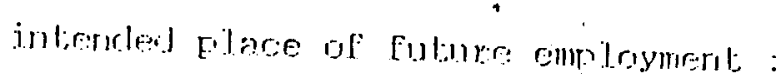

rovinc:e:

rane apriliant. :

father:s nome:

vj.1. 1.35 s:

district:

puovince :

intended rilace of futine remployment:

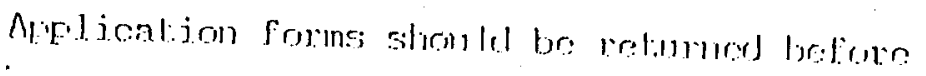

Studentes are asted lo arrive ol: ben mi

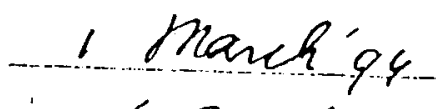

$16 \operatorname{con} 2$

name and adrleses of sording Hal:

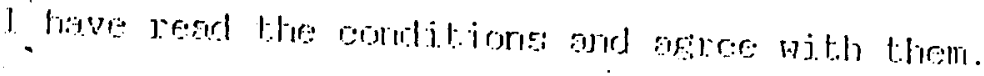

$(\operatorname{sinntang}$

name:

dalie: 


\section{$\triangle O B A R$ \\ VETERINARY SUB-COMHITTEE MERTING \\ Tuesday 8 March. 1994}

I. Approval of the agenda

The agenda was approved.

II. Minutes of the previous meeting

The minutes were spproved.

III. Announcements:

DCA announced that they have received a memorandum from $A C B \triangle R$ saying that a letter form HGOs might help their staff in getting through the border, but added that their staff with a letter of the agency were unable to cross the border. It was further said that recently issued ID cards by Commissionerate for Afghan Refugees were not effective either.

Follow up work by ACBAR was strongly requested in this connection. It was clarified that ACBAR is still tryine its very best to encourage the Pakistani Authorities to resolve the problem.

IV. Iasurance of veterinary field sitaf:

The issue wass discussed with UNDP last year, but not agreed on. One of the problems of such insurance was indicated that Pakistari Insurance Companies do not accept insurance of the staff inside Afghanistan. It ras suggested that the issue should be included in agenda for the next meeting, which will take place at $8: 30$ Tuesday 5 Apri1 1834, and agencies were requested to come up with ways and means as to how approach this matter in a proper fashjon.

v. Construction of yeterinary clinics in a standard design It was mentioned that the UN budget allocation for construction of a Veterinary Clinic is Rs. 25,000 which is inadeguste. It was clarified that the construction cost deperids on locality, labor wage, situation and number of rooms in a. clinic.

GAF reported that they have constructed a tow-roon clinic in Paktia and Nangarhar provinces each for Rs. 25,000 whereás a four-room clinic in Logar province cost them Rs. 60,000.

MADERA has spent Rs. 40,000 on a 3-roum clinic in Kamdish, Kunar province.

DCA reported that thej have desiened veterinary clinic which could be constructed for $8-12$ hundred thousand Afghani.

As it was reported that UNDP has accepted to pay Rs. 40,000 for construction of a veterinary clinic, it was suggested 
that Dr. Mehraban of UNDP should be invited to the rext meting for further clarification on the issue.

VI. Map production for veterinary activities

DCA submitted a map, indicating exact location of agency's; veterinary activities in Afghanistan. DCA was thanked for a prompt respond. Other agencies were requested to provicle a map of the same nature on their veterinary activities 50 that a single map could be eroduced accordingly. UNDP promised to send a map indicating veterinary activities of NGOs all"over the country.

VII. Any ather busines:

Bram Schreuder, Member of Board - DCA, had a sidide show on survey carried out on "Livestock mortality in Afghanistan in districts with and without veterinary program". Report of the survey is attached.

The Participants:

- M. Halimi (CHAIRMAN) DCA

- Bram Schreuder DCA

- M. v. d. Dool DCA

- M. Sabir Tahir

- Eng. Esmatuilah

- Dr. Ghafoor Khan

- Abdullah Khan

- Dr. A. Zahir

- M. Astef Rashid

- Dr. Ghulam Mohammad

- Abdullah Qaderdan

- Dr. Sediquila

- Dr. Amir Mohammad

- Dr. M. Kazem

- Dr. Sayed Mohammad

- Shafiq Ahmad

MADERA

ADA

GAE

ARDA

CRAA

RAFA

ARC

$A R C$

UNDP

UNDP

PRB

ACBAR

- ACBAR 


\title{
Livestock mortality in Afghanistan in districts
}

\section{with and without a veierinary programme}

\author{
preliminary report on an impact study
}

Bram E.C.Schreuder**, DVM; Nicolaas Noorman*** Mohibullah Halimi** , DVM, MVsc; and Gerrit Wassink**, DVM .

* DLO-Central Veterinary Institute, P.O. Box 65, Lelystad. The Netherlands

"DQAi-Veterinary Training and Support Centre, Monito:ing Dept., Univ. P.O. Box 792, Peshawar, Pnkistan

DESCRIPTORS: Epidemiology-; Afghanistan-; Cattle-diseases; Mortality-rates; Sheep-diseases; Goat-diseases; Mortality-; Ruminants-; Disease-surveys; Surveys-; Cattle-; Sheep-: Goats-; Livestock-; 
This paper reports on livestock mortality in a country where a war has been going on for more than a decade, with, as one of the consequences, complete disruption of the veterinary field services. The study was an effort to measure, in a limited number of districts of Afghanistan, the impact of a veterinary field programme carried out mainly by paravets. The study also provides valuable data on the impact of diseases in the absence of any veterinary intervention.

The veterinary programme, implemented by a Dutch NGO in these districts for approximately 3 years, consists essentially of a preventive vaccination programme against major infectious diseases. Another important part of the programme is the provision and - administration of anthelmintic drugs, both against nematodes and liver flukes. Veterinary personnel is, in addition to preventive actions, also involved in curative treatments.

Livestock mortality figures covering a period of two years were collected on livestock belonging to farmers in four districts with (covered) and four districts without (control) a veterinary programme. This was done by means of a questionnaire survey, administered by neutral enumerators. More than 700 farmers were interviewed in the analyzed districts and in at random selected villages, half of them in covered areas, the other half in control areas.

Annual mortality was defined as ine number of animais dying during an observation period of one year as proportion of the animals present at the start of the same observation period. For young animals, mortality was defined as the number of young animals dying as proportion of the animals born in the same observation period.

Summarizing for the two year period, this figure was for young animals:

$16.2 \%, 17.3 \%$, and $19.1 \%$ in the covered areas, against $21.5 \%, 25.2 \%$, and $24.6 \%$ in the control areas, for calves, lambs, and kids, respectively.

Adult mortality figures were considerably lower: $3.8 \%, 7.4 \%$, and $5.4 \%$ in the covered areas, against $5.3 \%, 13.6 \%$, and $15.6 \%$ in the control areas, for catte, sheep, and goats, respectively.

The survey indicated a significant difference $p<0.05$ in cattle, $p<0.001$ in small ruminants) in livestock mortality between the control and covered areas: the mortality in young animals was reduced by roughly 25,30 , and 22 percent, in calves, lambs, and kids. respectively. Adult mortality was reduced by roughly 30, 40, and 60 percent, in cattle. sheep, and goats, respectively. It is assumed that the preventive actions were responsible for most of the effect of the animal health programme. 


\section{INTRODUCTION, BACKGROUND, AND SCOPE OF THE STUDY}

The livestock sector is of major economic importance to Afghanistan, providing important constituents of the daily diet and a source of income for more than $80 \%$ of the population. The Soviet invasion in December 1979 triggered off a decade of war in which complete villages, cities, and most of Afghanistan's infrastructure, including irrigation canals, were destroyed. Human death toll exceeded one million, and more than 5 million people, equalling one-third of the population, fled the country. Rural Afghanistan witnessed in this period a complete disruption of veterinary services, a situation still continuing over large areas. This has led to serious threats to the already decimated livestock population. The agriculture survey carried out by the Swedish Committee for Afghanistan (SCA) in 1988 indicated that numbers of livestock inside Afgharistan were approximately half of pre-war figures (SCA 1988).

With the establishment in September 1988 of the Veterinary Training and Support Centre (VTSC) in Peshawar, Pakistan, by the Dutch Committee for Afghanistan (DCA), an emergency orientated veterinary programme was commenced, ained at providing basic veterinary care for the remaining Afghan livestock population. The DLO-Central Veterinary Institute (CDI-DLO) has provided technical backstopping from the inception of the project. A number of other organizations, most of them NGOs (non-governmental organizations), also got involved in veterinary activities, and DCANTSC has trained paravets for a number of them. The German-Afghanistan Foundation (GFF), also operating from Peshawar, Pakistan, was the first organization involved in this field. Otiner NGOs, among them Experiment in International Living (EIL), had their base in Quetta, Pakistan, and concentrated their inputs in South-Western Afghanistan. In 1990, after the withdrawal of the Soviet army, also the Food and Agriculture Organization of the United Nations (FAO) moved in, with as basis government-controlled Mazar-i-Sharif, aiming at providing veterinary services to livestock holders in Northern Afğhanistan.

The training of intermediate level veterinary auxiliary staff ("paravets") was undertaken. Students were recruited, in close consultation with local commanders or with other local authorities ("shura"), from areas where need for veterinary assistance was identified. Upon graduation, students were deployed in these areas inside Afghanistan, within the structure of "Veterinary Field Units" (VFUs) under the supervision of higher qualified veterinary personnel. Their tasks are primarily in prevontive veterinary medicine: vaccination campaigns against major infectious diseases in large and small ruminants and in poultry. Vaccinations are done at regular basis against anthrax, blackleg, enterotoxaemia, haemorrhagic septicaemia (HS), and Newcastle disease in target animals. HS vaccinations are done in certain regions in the South-East only. Another important part of the programme is the provision and administration of anthelmintic drugs, both against nematodes and.liver flukes. In the absence of any reilable recent data on disease incidence in Afghanistan, the field programme had been based on disease reports from $F A O-$ implemented projectsin the early sevenises and even earlice (FAO technical reports, 1955 and 1973). These reports stress the importance of parasitic diseases in this country, which is in line with the first author's own 2 years field experience in the North-Eastern provinces of Atghanistan. Veterinary personnel is, in addition to these preventive actions, also involved in curative treatments.

The personnel in the Veterinary Field Units is posted in such a way that they can be expected"to cover most of a district, each of them being assigned to a different duty station within that district. The field programme witnessed a modest start in spring 1989, with the establishment of the first VFUs. By tire end of 1992, the DCA/VTSC field programme covered, to a varying degree, 33 districts in 13 different provinces (out of 29). 
for logistic reasons concentrated in the East-Central, North-Eastern and Eastern regions (see map).

Gradually the DCA-VTSC programme has changed from an emergency orientated programme to a rehabilitation programme for veterinary infrastructure and services. In certain districts, field activities had been going on for three years, allowing an evaluation of the impact of the programme.

This paper reports on a survey on livestock mortality. The survey is limited to districts where activities were initially started, using as "control" areas, adjacent or nearby districts that had been devoid of organised veterinary care for more than 10 years. The collection of data on livestock-production and health under war-like conditions make the survey unique in its kind, but the same prevailing conditions entailed numerous practical and methodological difficulties.

\section{OUTLINE OF THE STUDY}

"How to assess the impact of a veterinary programme?"

In general terms the aims of the concerned animal health programme are:

1 ) to prevent losses of livestock, and

2) to increase productivity of existing livestock.

Under "normal" conditions, measurement of the impact of such a scheme should include checking disease incidence (disease surveillance) and the impact on production and mortality. This was not feasible under the given circumstances as cold-chain facilities were lacking and laboratory confirmation of disease outbreaks could be considered virtually nonexistent. What remained possible were farmers questionnaires. The survey focused on the collection of data on livestock productivity and mortality over a period of two years. In this report, only the data on livestock mortality will be presented.

\section{METHODS}

\section{1 Study population and selection of survey areas}

\section{Selection of control districts and matching of districts:}

Initially, 7 districts that had, according to the available information, 3 years functional animal health coverage, were selected in 6 different provinces. These were called the "covered districts". An equal number of "control". districts was selected, areas where no veterinary care had been available for, say. 10 years. Most of the latter districts were adjacent to the covered districts. Care was taken to ensure that the control areas were comparable with the areas covered by the animal health programme, in respect to ecological conditions and animal husbandry. This would allow for a comparison between pairs of districts.

\section{Selection of villages and farmers:}

Three villages were randomly selected within each selected district, both covered and control. To this end, a list of villages for each of these districts was drawn up and villages were given a numerical code (according to the Provisional Gazetteer, Ministry of Interior, Kabul, 1975). A random selection was made from these using a random number generator. 
In each selected village. 30 farmers were to be interviewed. Selecting 10 large, average, and small farmers per village, this sample should be representative for the whole village. This brought the total of interviewed farmers to 90 in each district.

\section{III.2. The questionnaire}

The questionnaire, prepared in "EPI-INFO" (Center for Disease Control, Atlanta/WHO. Geneva), was used in the summertime, which is after the lambing season and also after the main calving season. Most of the questions covered a period of two years, the two years immediately preceding the survey. The questionnaire covered a number of items, but for this preliminary report only the questions dealing with mortality are considered.

A distinction was made between mortality among young and a du!t animals, mainly because dirferent rates in these different groups have a direct impact on the productivity of a livestock population. Differentiating between these tı groups may also assist in pointing out lacunae in the animal health scheme.

In addition, questions were included on the presence or absence of animal health measures, the availability of medicines and anthelmintics, and on the numbers of livestock owned, in particular for large and small ruminants.

\section{Iil.3. The enumerators}

The enumerators administering the questionnaires of this survey were trained staff of the Agriculture Survey Department of the Swedish Committee for Afghanistan (SCA) (thus from an organization differing from the implementing agency), most of them having approximately five years experience in this field. The enumerators received additional instruction prior to their missions and were debriefed upon complecion of the survey. The field work was carried out in the summer and early autumn of 1992. On average, it took each enumerator two months to complete his district, including travel time.

\section{III.4. Analysis of results}

Analysis of the data was done using Lotus spreadsheet programme vs.3. For statistical analysis Statcalc was used, the statistical module of EPI-INFO (CDC/WHO). For calculating statistical differences between the individual pairs of districts and the combined figures, a contingency table was used (Chi-square) with Yates correction.

Annual mortality (in adult animals) was defined as the number of animals dying during an observation period of one year as proportion of the animals present at the start of the same observation..period.

Animals sold, given away or consumed -- not the ones slaughtered clue to disease -- were counted only half, as they were not at risk for the full period. For sinall ruminants, where this number was only available for the period of the last 12 months, a similar offake was assumed for the previous year.

For young animals, mortality was defined as the number of young animals dying as proportion of the number of animals born in the same observation period. For small ruminants this was a period of approximately five to six months, ie the period between lambing season and time of implementing the survey. The latter coincided roughly with the period of weaning. For calves, weaning usually is done very gradually, at an age of one year, which also delineates the obșervation period. 
Initially, we intended to consider young animals "young" until mated, which is in general in Afghanistan, two years for cattle and eight to nine monthis for sheep and goats. For the latter, this created no analytical problems, however, nost farmers prefered to talk in case of young cattle about "calves", meaning suckling caives, which reduced this group of young animals to calves till about one year oge. What happened to the group of one to tivo years old is not completely clear, but presumably this confusion took place irrespective of project's involvement and therefore not affecting the results of this study.

\section{RESULTS}

\section{IV.1. Districts surveyed and districts qualifying for analysis}

- The survey was finally implemented in 10 districts, in four different provinces. The more Northern provinces could not be reached at the time of the survey, due to severe fighting in the areas on the way.

The major criterion applied when selecting the covered districts, had been the presence of two to three years coverage by DCA-VTSC. For the control districts the major criterion had been the absence of any animal health programme. Two districts did not comply with these criteria, and did therefore not qualify for being included in the analysis of the survey results.

In the end, four pairs of districts, in four different provinces remained for analysis (see mapl.

\section{IV.2. Mortality in cattle in 4 pairs of districts}

Data were collected with regard to mortality in cattle, both in calves and in adults for the four pairs of districts. In the three villages selected in each district, a minimum number of 100 adult heads of cattle should be present on an average for both years of the survey. Statistical analysis was done initially within each of the pairs and $p$-values for each pair calculated. Only in two of the four pairs a (highly) significant difference in favour of the covered district was noted for adult cattle, and in three pairs for calves.

The overall figures, combined for the four districts and for both years of the survey, show a highly significant lower mortality for calves $(p<0.01)$ and a significant lower mortality for adults $(p<0.05)$ in the covered districts, as compared to the control districts. (Table $1)$.

\section{IV.3. Mortality in sheep in 4 pairs of districts}

Data with regard to mortality in sheep, both in lambs and in adults, for the four pairs of districts were collected and analyzed. In one district, numbers of sheep were considered too small $(<200)$ to allow proper comparison with its counterpart. When compairing the remaining three pairs of districts, a (highly) significant difference in favour of the covered district was noted, for both adults and lambs alike.

The summary tabie (Table 2), however, contains data from all four pairs of districts. The figures combined for both years and for the four pairs of districts show a significant lower mortality for both lambs and adults in the covered districts, as compared to the control districts. In both cases the difference was highly significant $(p<0.001)$. 


\section{IV.4. Mortality in goats in 4 pairs of districts}

Data on mortality in goats both in kids and in adults, were collected for the four pairs of districts. Again, in each district a minimum number of 200 adult goats should be present on an average for both years of the survey. When compairing the four pairs of districts, a highly significant difference in favour of the covered district was noted for adults in four pairs, for kids in three pairs.

The figures, combined for the four pairs of districts and for both years of the survey (Table 3), show a significant lower mortality for botn !ids and aduits in the covered districts, as compared to the control districts. In both cases the difference was highly significant $(p<0.001)$.

IV.5. Summary of differences in livestock mortality between the control and covered districts (see also Figure 1)

Summarizing for the two year period, mortality in young animals was:

$16.2 \%, 17.3 \%$, and $19.1 \%$ in the covered areas;

$21.5 \%, 25.2 \%$, and $24.6 \%$ in the control areas;

for calves, lambs, and kids, respectively.

Adult annual mortality figures were considerably lower:

$3.8 \%, 7.4 \%$, and $5.4 \%$ in the covered areas:

$5.3 \%, 13.6 \%$, and $15.6 \%$ in the control areas:

for cattle, sheep, and goats, respectively.

The survey indicated a significant difference $i p<0.05$ in cattle, $p<0.001$ in small ruminants) in livestock mortality between the contrcl and covered areas: the mortality in young animals was reduced by roughly 25,30 , and 22 percent, in calves, lambs, and kids, respectively. Adult mortality was reduced by roughly 30,40 , and 60 percent, in cattle, sheep, and goats, respectively.

\section{DISCUSSION}

This paper reports on livestock mortality figures in a country where for more than a decade a complete war has been going on, with as one of the consequences a complete disruption of the veterinary field services. Thie reported study was an effort to measure the impact of a field programme, carried out by mainly paravets in a number of districts of Afghanistan.

The impact of the programme seems to be the greatest for adult small ruminants, which constitute by far the most numerous and important type of livestock in Afghanistan. The impact seems lower, however, for adult cattle and, to a lesser extent, for young animals of all three investigated species. The confirmed presence of Rinderpest in Nangarhar province in $1991 / 92$ la clinical, preliminary diagnosis was confirmed serologically by the CDI-DLO, The Netherlands) could have confounded the piciure for cattle, as the project was not equipped for adequate interventions (lack of coldchain facilities). 
In general, the mortality figures found in the present survey for young animals are comparable with resuits from studies in other countries, such as Mali (Traore \& Wilson 1988), where mortality in young animals was $10 \%, 28 \%$, and $35 \%$ in caives, lambs, and kids, respectively, and india (Bali et al. 1980), where the overall mortality in calves up to one year of age was $18.4 \%$.

Adult mortality figures are also comparable with studies in other countries, like the one in Mali (Traore \& Wilson 1988), where adult mortality was about $5 \%$ per year in cattle and $12-13 \%$ per year in sheap and goats. The figures in the covered areas even tend to be lower than in the Mali suivey reported, and at times seem to approach figures in countries with a well-developed veterinary infrastructure. For comparison, we present data from New Zealand (Davis 1974), where an adult annual mortality of $4.9 \%$ was found in sheep, while in the UK the annual ewe-losses are estimated at $10 \%$ (Hindson \& Winter 1990).

\section{Passibie bias introduced by the farmers or enumerators:}

It is difficult to assess the amount of possible bias introduced by the farmers answers to the questions. Farmers probably all over the world show a tendency to adjust their statements in such a way that they think might be beneficial to them. Afghan farmers will certainly not be an exception. It may therefore be conceivable that farmers in areas without veterinary services may exaggerate their problems, in the hope that this way these services may become avallable earlier. It has been a specific topic during the briefing of the enumerators to pay attention to this possibility. The questionnaire also contained several cross-chcck questions, allowing for internal checking.

The enumerators employed for this survey were experienced and trained in this field of work. In addition, they had been recruited from a neutral organization outside DCA-VTSC. the project-implementing organization, to avoid a possible bias introduced by using field staff involved in the veterinary programme. The enumerators had no direct interest in the outcome of the survey.

\section{Discussion on the effect of the programme:}

A highly significant difference in mortality between the covered and control areas was demonstrated: the mortality in young animals was reduced by roughly 25,30 , and 22 percent, in calves, lambs, and kids, respectively. Adult mortality was reduced by roughly 30,40 , and 60 percent, in cattle, sheep, and goats, respectively.

The veterinary programme implemented in the covered areas for approximately 3 years, consists mainly of a preventive vaccination programme against major infectious diseases, as Anthrax, Blackleg. Enterotoxaemia and other Clostridial diseases. In rare instances vaccination against Foot and Mouth disease (FMD) was carried out. Another important part of the veterinary programme is the provision of anthelmintic crugs, both against nematodes and liver, fluke. In addition, the field personnel is involved in curative treatments. No effort was made, however, to differentiate between the effects of the various components of the programme.

Because infectious and parasitic diseases have always caused considerable losses to livestock in Afghanistan, also in periods before the war (FAO reports 1955, 1973), it is assumed that the preventive veterinary actions have been responsible for most of the effect of the animal health programme. This is indirectly supported by the greater impact on mortality in adult animals as compared to the effect in young stock. Future inputs of 
Initially, young animals were intended to be considered "young" unil mated, which is in general in Afghanistan, two years for cattle and eight to nine months for sheep and goats. For the latter, this created no analytical problems, however, most farmers prefered to talk in case of young cattle about "calves" meaning sucking calves, which reduced this group of young animals to calves till about one year age. What happened to the group of one to two years old is not completely clear, but presumably this confusion took place -irrespective of project's involvement and therefore not affecting the results of this study.

\section{RESULTS}

\section{IV.1. Districts surveyed and districts qualifying for analysis}

The survey was finally implemented in 10 districts, in four different provinces. The more Northern provinces could not be reached at the time of the survey, due to severe fighting in the areas on the way.

The major criterion applied when selecting the covered districts was prior coverage for two to three years by DCA-VTSC. For the control districts the major criterion was the absence of any animal health programme. Two districts did not comply with these criteria, and were therefore not included in the analysis of the survey results.

In the end, four pairs of districts, in four different provinces remained for analysis (see map).

\section{IV.2. Mortality in cattle}

Data were collected with regard to mortality in cattle, both in calves and adults for the four pairs of districts. In the three villages selected in each district, a minimum number of 100 adult cattle should be present on average, for botin years of the survey. Statistical analysis was done initially within each of the pairs and $p$-values calculated for each pair. Only in two of the four pairs a (highly) significant difference in favour of the covered district was noted for adult cattle, and in three pairs for calves.

The overall figures, combined for the four clistricts and for both years of the survey, show a highly significantly lower mortality in calves $(p<0.01)$ and a significant lower mortality in adults $(p<0.05)$ in the covered districts, compared to the control districts. (Table 1$)$.

\section{IV.3. Mortality in sheep}

Data were collected and analyzed with regard to mortality in sheep, both in lamis and aciults, for the four pairs of districts. In one district, numbers of sheep were considered too small $(<200)$ to allow proper comparison with its counterpart. When compairing the remaining three pairs of districts, a highly significant cifference in favour of the covered district was noted, for both adult sheep and lambs alike.

The summary table (Table 2), however, contains data from all four pairs of districts. The figures combined for both years and for the four pairs of districts show a significantly lower mortality in both lambs and adults in the covered districts, compared to the control districts. In both cases the difference was highly significant $(p<0.007)$. 
Data on mortality in goats both in kids and in adults. were collected for the four pairs of districts. Again, in each district a minimum number of 200 adult goats should be present on average for both years of the survey. When compairing the four pairs of districts, a highly significant difference in favour of the covered district was noted in adult goats in four pairs, in kids in three pairs.

The overall figures, combined for the four pairs of districts and for both years of the survey (Table 3), show a significantly lower mortality in both kids and adult goats in the covared districts, compared to the control districts. In both cases the difference was highly significant $(p<0.00 \%)$.

IV.5. Summary of differences in livestock mortality between the control and covered cistricts (see also Figure 1)

Summarizing for the two year period, mortality in young animals was:

$16.2 \%, 17.3 \%$, and $19.1 \%$ in the covered areas:

$21.5 \%, 25.2 \%$, and $24.6 \%$ in th, control areas;

in calves, lambs, and kids, respectively.

Adult annual mortality figures were considerably lower:

$3.8 \%, 7.4 \%$, and $5.4 \%$ in the covered areas:

$5.3 \%, 13.5 \%$, and $75.6 \%$ in the control areas;

in catile, sheep, and goats, respectively.

The survey indicated a significant difference $(\rho<0.05$ in cattle, $p<0.007$ in sinall ruminants/ in livestock mortality between the control and covered areas: the mortality in young animals wos reduced by roughly 25,30, and 22 percent, in calves, lambs, and kids, respectively. Adult mortality was reduced by roughly 30,40 , and 60 percent, in cattie, sheep, and goats, respectively.

\section{DISCUSSION}

This paper reports on livestock mortality figures in a country where a devastating war has been going on for more than a decade, with as one of the consequences a complete disruption of the veterinary field services. The reported study was an effort to measure the impact of a field programme, carried out mainly by paravets in a number of districts of Afghanistan.

The impact of the programme seems to be the greatest for adult snall ruminants, which constitute by far the most numerous and important type of livestc k ir Afghanistan. The impact seems lower, however, for adult cattle and, to a lesser exte..., for young animals of all three investigated species. The confirmed presence of Rinderpest in Nangarhar province in 1991/92 (a preliminary clinical diagnosis was confirmed serologically by the CDI-DLO. The Netherlands) could have confounded the picture for cattle, as the project was not equipped for adequate interventions (lack of coldchain facilities).

In general, the mortality figures found in the present survey for young animals are comparable with results from studies in other countries, such as Mali (Traore \& Wilson 1988), where mortality in young animals was, 10\%, 28\%, and 35\% in calves, lambs, and 
kids, respectively, and India (Bali et al. 1980), where the overall mortality in calves up to one year of age was $18.4 \%$.

Aduli mortality figures are also comparable with studies in other countries, such as in Mali (Traore \& Wilson 1988), where adult mortality was about $5 \%$ per year in cattle and $12-13 \%$ per year in sheep and goats. The figures in the covered areas even tend to be lower than in the Mali survey, and at times seem to approach figures in countries with a well-developed veterinary infrastructure, for example, in New Zealand (Davis 1974), where an aduit annual mortality of $4.9 \%$ was found in sheep, while in the UK the annual eweiosses are estimated at $10 \%$ (Hindson \& Winter 1990 ).

\section{Possible bias introduced by the farmers or enumerators:}

It is difficult to assess the amount of possible bias introduced by the farmers' answers to the questions. Farmers, probably all over the world, may show a tendency to adjust their statements in such a way that they think might be beneficial to them. Afghan farmers will certainly not be an exception. It may, therefore, be conceivable that farmers in areas without veterinary services may exaggerate their problems, in the hope that in this way these services may become avalable earlier. It was a specific topic during the briefing of the enumerators to pay attention to this possibility. The questionnaire also contained several cross-check questions, allowing for internal checking.

The enumerators employed in this survey were experienced and trained in this field of work. In addition, they had been recruited from a neutral organization outside DCA-VTSC, the project-implementing organization, to avoid a possible bias introduced by using field staff involved in the veterimary programme. The entmerators had no direct interest in the outcome of the survey.

\section{Discussion on the effect of the programme:}

A highly significant difference in mortality between the covered and control areas was demonstrated: the mortality in young animals was reduced by roughly 25, 30, and 22 percent, in calves, lambs, and kids, respectively. Adult mortality was reduced by roughly 30,40 , and 60 percent, in cattle, sheep, and goats, respectively.

The veterinary programme implemented in the covered areas for approximately 3 years. consisted mainly of a preventive vaccination programme against major infectious diseases such as Anthrax. Blackleg. Enterotoxaemia, and other Clostridial diseases. In rare instances vaccination against Foot and Mouth disease (FMID) was carried out. Another important part of the veterinary programme is the provision of anthelmintic drugs, both for nematodes and liver fluke. In addition, the field persomel was involved in curative treatments. No effort was made, however, to differentiate between the effects of the various components of the programme.

Because infectious and parasitic diseases have always caused considerable losses to liveștock in Afghanistan, also in periods before the war (FAO reports 1955,1973 ), it is assumed that the preventive veterinary interventions have been responsible for most of the effect of the animal health programme. This is indirectly supported by the greater impact on mortality in adult animals as compared to the effect in young stock. Future inputs of the veterinary programme should therefore concentrate on problems in young animals, without forsaking the present apparently beneficial constituents of the programme. 


\section{Acknowledgements}

The assistance of Mart de Jong and Herman Barkema in the design of the stuoy is greatfully acknowledged. During the implementation of the survey, valuable support was received from Abdul Hakim Murad and Dr. Azam Gul, both from the Agriculture Survey Department of the Swedish Committee for Afghanistan. This organization also provided the enumerators, without whom a survey of this scope would have been virtually impossible. Finally, we want to acknowledge the veterinary field personnel of the Dutch Committee for Afghanistan (DCA), whose activities laid the base for the results described in this study.

\section{References:}

Bali MK; Khanna RNS; and Singh RP. (1980). Calf mortality in Hariana cattle and their cross-breds. Indian Veterinary Medical Journal, 4(3): 115-118

Davis, GB. (1974). A sheep mortality survey in Howke's Bay. New-Zealand Veterinary Journal, 22 (4): 39.42 .

FAO Report to the Gove:nment of Afghanistan. (1955). The control of sheep diseases and parasites. FAO Report No. 336, by MacPherson. D.A., FAO Rome.

FAO technical report, UNOP/SF project 210 (AFG/511) (1973). Final report of epizootiologist, Blaga, M.D., Kabul.

Hindson JC \& Winter AC. (1990). Outline of clinical diagnosis in sheep. Butterworth \& Co. (Publishers) Ltd. London, UK, p 62.

Swedish Committee for Afghanistan. (1988). The agriculture survey of Afghanistan. First Peport, May, $68 \mathrm{pp}$.

Traore A. \& Wilson RT. (1989). Livestock production in central Mali: environmental and pathological factors affecting morbidity and mortality of ruminants in the agropastoral system. Preventive Veterinary Medicine, 6 (7): 63-75

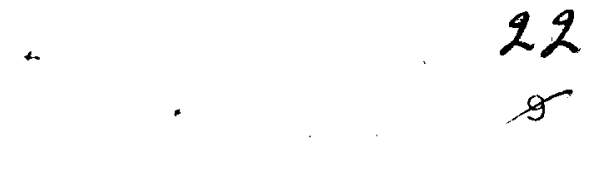


Table 1: Cattle mortality in four pairs of districts in Aighanistan. calculated over a period of two years

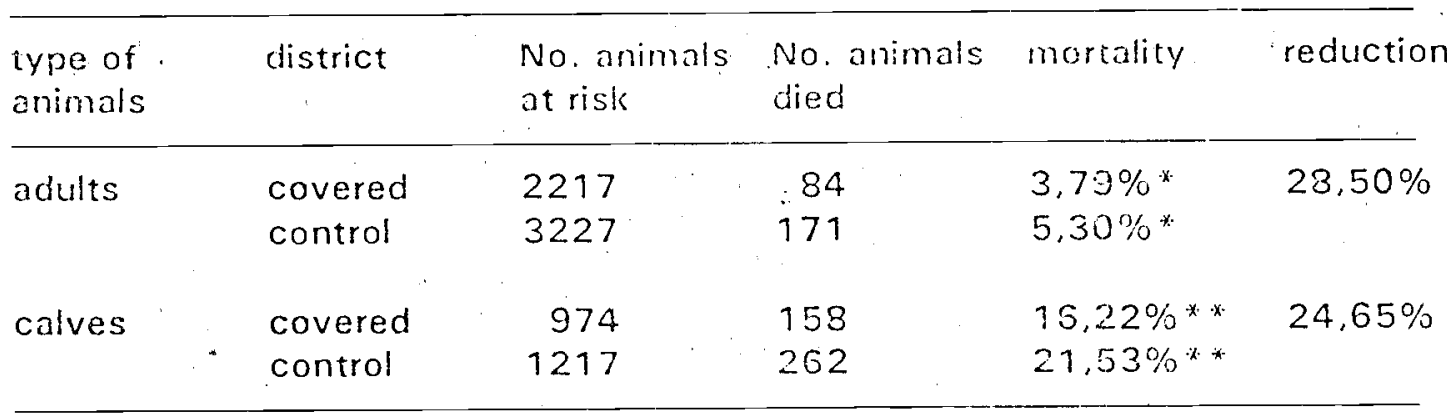

* signiricant difference, $X^{2}=6.38, p<0.05$

* * highly significant difference, $X^{2}=9.49, p<0.01$

Table 2: $\quad$ Sheep mortality in four pairs of districts in Afghanistan. calculated over a period of two years

\begin{tabular}{|c|c|c|c|c|c|}
\hline $\begin{array}{l}\text { type of } \\
\text { animals }\end{array}$ & district & $\begin{array}{l}\text { No, animals } \\
\text { at risk }\end{array}$ & $\begin{array}{l}\text { No. animals } \\
\text { died }\end{array}$ & mortalicy & reduction \\
\hline adults & $\begin{array}{l}\text { covered } \\
\text { control }\end{array}$ & $\begin{array}{r}9047 \\
14433\end{array}$ & $\begin{array}{r}745 \\
1960\end{array}$ & $\begin{array}{r}8,23 \% * * * * \\
13,58 \% * * *\end{array}$ & $39,36 \%$ \\
\hline lambs & $\begin{array}{l}\text { covered } \\
\text { control }\end{array}$ & $\begin{array}{l}4330 \\
8621\end{array}$ & $\begin{array}{r}837 \\
2172\end{array}$ & $\begin{array}{l}17,33 \% * * * \\
25,19 \% * * *\end{array}$ & $31,22 \%$ \\
\hline
\end{tabular}

*** highly significant dirference, $x^{2}$ (achlls) $=156 ; p<0.001$

$X^{2}$ (lambs) $=709 ; p<0.001$

Table 3: Goat mortality in four pairs of districts in Afghanistan, calculated over a period of tro years

\begin{tabular}{llrrrr}
\hline $\begin{array}{l}\text { tyoe of } \\
\text { animals }\end{array}$ & district & $\begin{array}{l}\text { No.animals } \\
\text { at risk }\end{array}$ & $\begin{array}{l}\text { No. animals } \\
\text { died }\end{array}$ & nortality & reduction \\
\hline adults & covered & 5814 & 349 & $6,00 \% * * * 61,57 \%$ \\
& control & 13701 & 2140 & $15,62 \% * * *$ & \\
kids & covered & 3343 & 639 & $19,11 \% * * * 22,16 \%$ \\
& control & 6524 & 1602 & $24,56 \% * * *$ & \\
\hline
\end{tabular}

*** highly significant difference, $x^{2}$ ladults) $=33 \varepsilon, p<0.001$

$x^{2}$ (kids) $=37,0 ; p<0.001$ 


\section{References:}

Bali MK; Khanna RNS; and Singh RP. (1980). Calf mortality in Hariana cattle and their - cross-breds. Indian Veterinary Medical Journal, 4(3): 115-118

Davis, GB. (1974). A sheep mortality survey in Hawike's Bay. New-Zealand Veterinary Journa! $22(4): 39-42$.

FAO Report to the Government of Aighanistan. (1955). The control of sheep diseases and parasites. FAO Report No. 336, by MacPherson, D.A., FAO Rome.

FAO technical report, UNDP/SF project 210 (AFG/511) (1973). Final report of epizootiologist. Blaga, M.D., Kabul.

Hindson JC \& Winter AC. (1990). Outline of clinical diagnosis in sheep. Butterworth \& CC. (Publishers) Ltd. London, UK, p 62.

Swedish Committee for Afghanistan. (1988). The agriculture survey of Afghanistan. First Repor, May, $68 \mathrm{pp}$.

Traore A \& Wilson RT. (1988). Livestock production in centra! Mali: environmental and pathological factors affecting morbidity and mortality of ruminants in the agropastorai system. Preventive Veterinary Medicine, $6(1): 63-75$. 


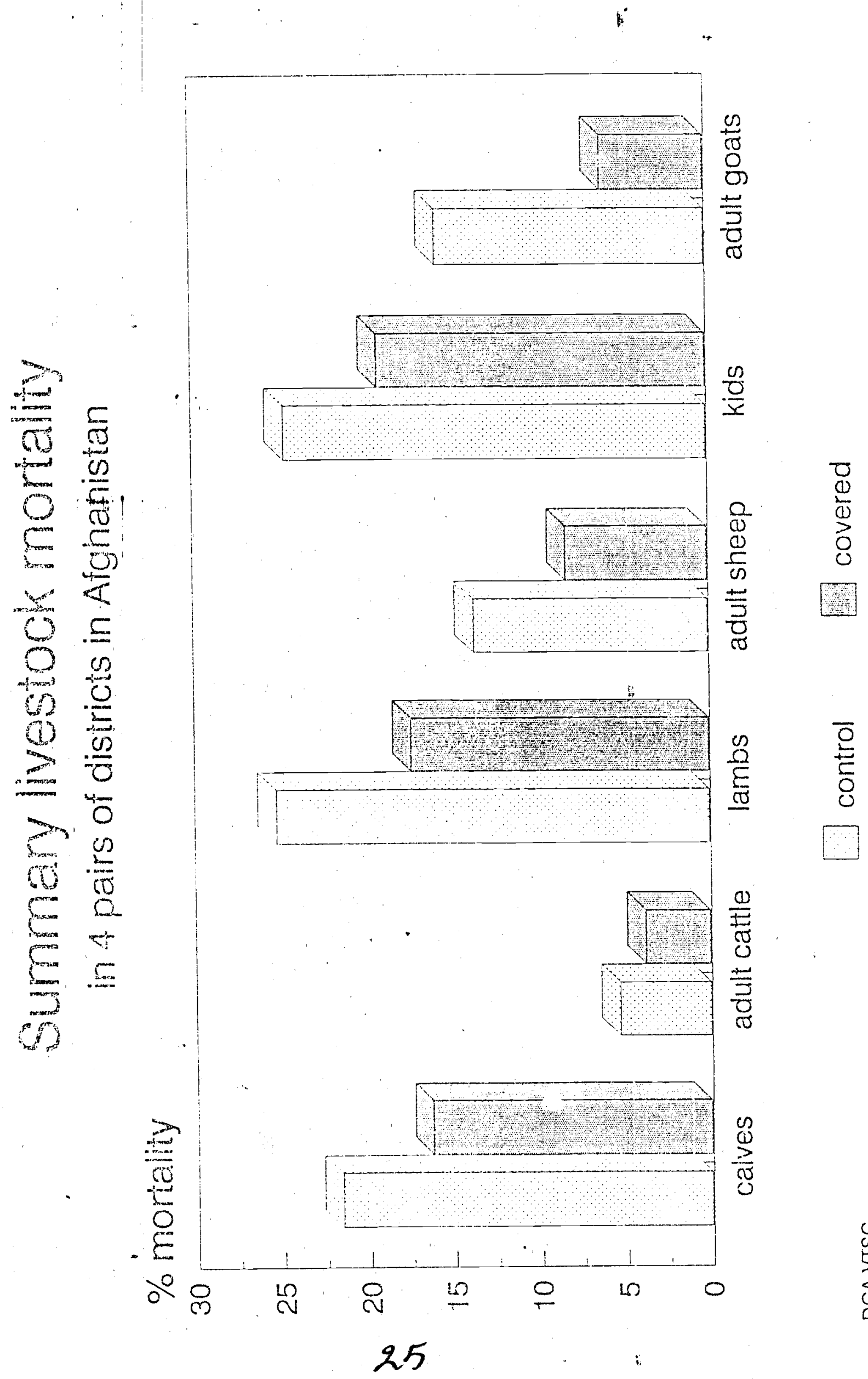

$\frac{0}{0}$ 


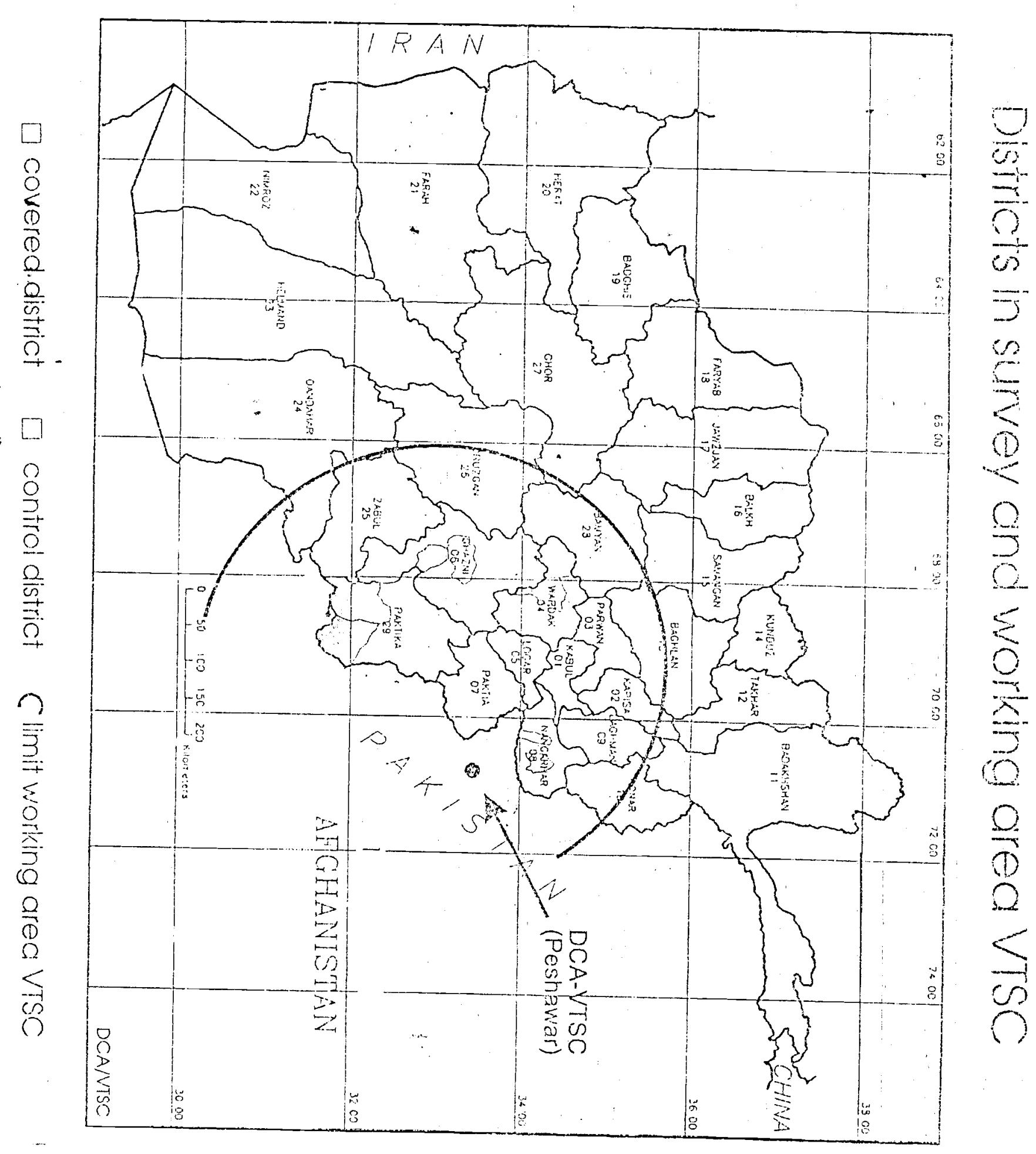




\section{$A C B \triangle R$ \\ VETERTAARY SUB-COHHILLEE MEEIJAG \\ TUESI $\Lambda Y 2 H A Y, \quad 1994$}

I. Approval of Agenda

The AeErida was approverl.

II Minutes af the previous meeting (Apri] 5, 1994)

The minutes; were ariroved.

\section{ITI Announcements}

Mr. Hagib Ahmad Hoory, row ACBAR Proeram Marager, was introfluced to the partiripants. He was weloomen by the Chairman.

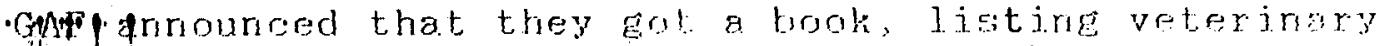
pubploations, from a German guest. A sub-group representing GAF, DCA, and llMDF was assigned to gelert romks: to be furchased for NoOs libraries.

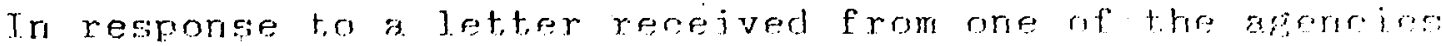
addressed to $\mathrm{F} \Lambda \mathrm{O}$, it was sugesested by UNDF hal, any queries/correspordence with reeard to veterinary programs wonld be dealt by UHDP, on behalf of the FAO, till FAO fully takes over the program.

IV. Yeterinary medicine and yaccine ciupply

UNDP has approved a 3-week tharmary Management trainine course for local. shor keepers, already selling veteringry medicines, on provincial level inside Afghanistan. A erroup of 20 student; one person per province vill be trajned in the rourse. The project is coritracted to PRB who will ase the technical services of $A$ ITH recogrized in the field of management training. .PRB and AITM will carry out jointly the selection of potential candidates;.

In response to a guestion as to whether such a course will be conducted in the future. IMDP stated that it, would repend on outcomeisurcess of the training.

UNDP announced that FNO will establish 5 zonal offices insside Afghanistan they will be supplying vaceines am medicines to the targeted VFus in the area of thein jurisdietion and ail be orolecting and moritoring fiold progress reports of the velus. The proposed seti up erovides nominal local transportation cost for varoines and medichnes tir the HGos; contrarting his servires. The future sumply of medirines ond vaceines inside Afghanistan will be bher caxe by FAO and private surplers.

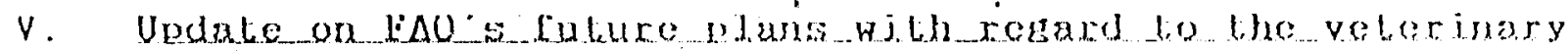
- 'rogrammes - UNDP/OP's l'eshawar

UMDP distribuled a dralt rooument a sample prepared for pre

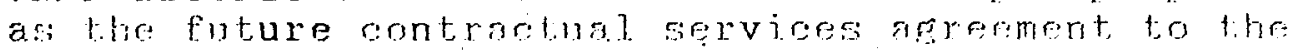

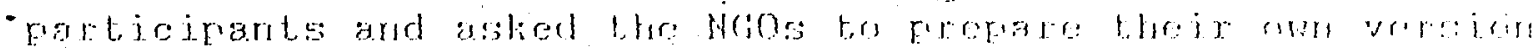
acoorlingly. The senior veterinary of defer JPLP, reguegted 3. metine of MGOs for Lheir comments on the document, which je reflecting EAO's ruliey with regard ter voterinary projects when they take over the program. HADF wi]l intorm

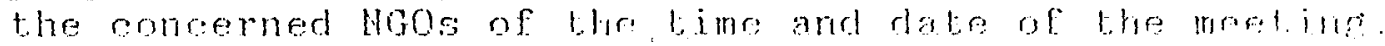


A kind of injustice with regard to the different levels of funding grants - supposed to be provided by FAO - was anticipated by DCA. It was said a VEU established long ago but with a staff newly appointed to the same VEU may not mean the staff enjoyed the benefits of the established-phase of the VEU economically or to the professional acquaintance with the farmers. The Chairman pointed out that some adjustment with regard to the pay scale, taking into consideration the individual status of the professional field staff as to the length of his service and whether the staft is local or not may help if the NGOs come up with a coordinated approach in thiss regard.

Vi. Production of a Map indicating veterinary clinics all over Afghanisitän.

ACBAR pointed out that at the last Sub-comittee meeting, DCA volunteered to produce a map indicating the locations of veterinary clinics all over Afghanistan. The concerned llgos had been requested to send their list of clinics to Shafia Ahmad in ACBAR, which will then be forwarded to DCA. So far, only GAF has sent the required information, for which ACBAR is grateful NGOs are requested to provide the information either to ACBAR or DCA directly. The Chairman sugeested that Quetta based NGOs and FAO should also be contacted to provide the reeded information to DCA so that rearly a complete map can be prepared.

ACBAR ofeice will Eollow up this issue with the Guetta based MGOs and $F A O$ and will try to collect the required information.

Lartigientsi

- llussaini (CHAJRMAN) GAF Ling. Esmal

- Dr. Ghulam Mohammed ARC

- Abdullah Qaderdar ARC

- Sanaul Haci A. Z CRAA

- Dr. Mohibullah Halimi DCA

- Dr. Tino Elerinecken DCA

- Dr. M. Kazem PRB

- Dr. A. B. Mehraban UNDP/OPS

- Dr. A. A. Nasseri UNDP/OPS

- Naqib A. Noory ACBAR

- Shafiq Atmad ACBAR 


\section{ACBAR \\ VETERINARY SUB-COMMITTEE MEETING \\ TUESDAY $5 \cdot$ JULY 1994}

Is both the chairman and deputy chajiman were not present at the moeting, Dr. Mehraban was requested to chair the meeting.

\section{T. Approval of Agenda}

The Agenda was approved.

1.T. Minutes of the previous meeting (June 7,1994 )

The minutes were approved.

\section{r.T.T. Announcements}

MADERA announced that their staff was in Kunar last week in Pashad area and the clinic reported the outbreak of Foot and Mount Disease (FMD). The paravet of that area'also sent a written report stating the same disease occurred in Koligram and shankar of sarkano district Kunar province. MADERA assessed the disease and as vaccin'ne" was not available for the disease, MADERA requested NGo's ideas how to prevent the disease.

MADERA conducted animal pregnancy course in Jalalabad last week.

In regards to the outbreak of the disease, the chairman said that vaccination would not be feasible, because FMD type should be isolated first, vaccine is not available and the price is too high which also requires cold chain facility. The chairman suggested application of antiseptics on lesions in the mouth under and claws of affected animals and in case of fever antibiotic treatment of sj.ck animals.

DCA suggested to look at the problem from different point of views - if the disease is an epidemic one, steps should be taken to prevent, other possibility for preventing such diseases, vaccination of all animals be done once a year.

DCA has negotiated and proposed establishment of 5 additional field units in Herat which will depend on FAOs support. No response has been received so far. FAO clarified that the proposals may not be supported at this stage. FAO will evaluate the situation and prefers a local NGO to work in Herat. In case of non availability of a local NGO, DCA or GAF will be considered.

IV. Update on FAo Final policy re: vet. programme

l'he transfer of the veterinary programme has been completed from UNDP/OPS to FAO. Dr. Naseri and Dr. Safi will remain with ops for two months, until the end of August to complete the ops funded projects and will then join FAO. Project proposals for 10 Implementing Partners have been approved. FAO is in the process of transferring funds for the projects which probably take place in 2 weeks. 
FAO is presently supporting 10 IPs, 6 in quetta and 4 in Peshawar. UNDP used to support 7 NGOs in Quetta - one has been removed from the list based on its limited activities and past experiences.

On Peshawar side, Agency for Rural Development of Afghanistan) will take over CRA's activities - they are in the process of transferring the VFUs from CRA to ADF.

FAO is going to establish a management office in Islamabad and regional offices in Afghanistan. FAO does not have any new programme in the current year.

The women programme will remain with UNDP/OPS, FAO will consider to support it after six months.

NGOs are requested to send final project reports to UNDP/OPS before 15th of July. FAO strongly recommend that NGOs submit their final reports to OPS on time so they could be audited by ops before FAO release the second installments.

DCA pointed out that Dutch Gov. funding will continue until Jan. 95.

In response to the question of supply of vaccines for 1994, FAO assured that funds for the purchase of vaccines is budgeted in the FAO documents for the 6 months of 1994 (July - December). Vaccines will be supplied in september.

On a query that how much vaccine will be given to NGOs and how will FAO measure the requirement, FAO in response said that 33,000 doses of vaccine will be given per VFU for six months.

\section{Any other business}

MADERA reported that a Doctor has resigned from GAF due to low salary and has applied for a job in MADERA office. MADERA's representative pointed out that the salary fixed for the DVM is too low which is 2800 and inquired if this was the standard salary.

FAO clarified that the salary is fixed 2500 not 2800 and FAO is not in a position to pay higher salary as the programme has been designed for self reliance, the doctors beside receiving 2500 can make their own profit by selling the medicines and charging for vaccinations and their services which seems to be justifiable.

DCA supported the idea and said that the estimated income to be received by doctors is $20 \%$ from the sale of medicine.

The UN will not force NGOs to pay higher salaries to their stafr, FAO, recommended that NGOS coordinate with each other. NGO willing to appoint existing staff member of other NGO should contact the agency for knowing the background of the individual and trustworthiness prior to appointing them.

DCA appealed to agencies to coordinate their activities with ACBAR regarding the establishment of new VFU's. The representative recommended that a 1 ist of new VFUs be sent to ACBAR for updating the existing map - which. was earlier prepared by DCA. 
GAF pointed out that NGOs have made several efforts and spent a lot of money in training the paravets. It will not be justifiable that the paravets completed their training - worked for some time with NGOs be terminated, because of fund:shortage. The individuals may be discouraged as their colleagues will be continuing to work at similar or lower level and they will not only lose the jobs but also their profession. GAF recommended that steps be taken in keeping the existing trained paravets.

The issue was discussed in light of the availability of funds for the veterinary sector, and it was believed that the issue was very important but NGOs could not keep the same personnel as they used to do in the past.

FAO asked agencies to address all matters related to the vet. programme to Dr. Sediqullah in Peshawar and Dr. Ebrahimi in Khost. The narrative and final financial reports has to be submitted to Islamabad. Reports of the VFUs in Khost, Paktia, Paktika, Wardak, Logar and Ghazni have to be sent monthly to FAO Khost Project office. The rest of VFUs functioning in the North-East and Central parts of the country have to be sent to FAO Peshawar Project office.

ADA is looking for a DVM and paravets who are willing to work in Khas Urozgan. Agencies having more staff may kindly refer and send interested candidates to Eng. Esmat, ADA office, 34-C/3A-1 Circular Rd. University Town, Peshawar - Tel. 44779/42230.

The next veterinary meeting will be held on the 19 th of July at the ACBAR office.

\section{Participants:}

- Dr. A. Mehraban (CHAIRMAN)

- Abdullah Qaderdan

- Dr. Tino Hennecken

- Sediqullah

- Dr. M. Amin Rahimi

- Q. Fazel Rabi

- Dr. M. Kazem

- Dr. Nasseri A.A.

- Naqib Ahmed Noory

$\begin{array}{lll}\text { FAO } & \text { - Eng. Esmat } & \text { ADA } \\ \text { ARC } & \text { - Dr. Ghulam M. } & \text { ARC } \\ \text { DCA } & \text { - Mustamir } & \text { FAO } \\ \text { FAO } & \text { - Ebrahimi } & \text { FAO } \\ \text { FAO } & \text { - Dr. Ghafoor Khan } & \text { GAF } \\ \text { GAF } & \text { Dr. Ghulam Saeed } & \text { MADERA } \\ \text { PRB } & - \text { M. A. Rashid } & \text { RAFA } \\ \text { UNDP } & & \\ \text { ACBAR } & \end{array}$


32 


\section{A C B A R \\ VETERINAPY SUB-COMMITTEE MEETING \\ TUESDAY 19 JULY, 1994}

I. Approval of Agenda

The Agenda was approved.

II. Minutes of the previous meeting (July 5, 1994)

Following correctlons were made to the minutes of the last meeting:-

Page 1, Para. " 6 should read "A veterinary governmental Inst Itutlon, whlch is concerned about this disease in terms of preventing epidemlcs can come to different concluslons to react to an outbreak of FMD than the single farmer, who wants to protect his 2 or 3 cows. From the point of view of the farmer it may be approprlate to protect his cows from FMD through vaccination (once a year). From the polnt of view of the veterinary institution, which is concerned about the whole country it may be approprlate not to vaccinate".

Page 1, Para. 7 "FAO has offered DCA to take over 5 veterinary Field Unlts in Herat province, which are currently under FAO supervision. There had already been a meeting between DCA and FAO prograrme manager, P. de Rover. The agreement for the award of the contract for the implementation of the said VFUs to DCA has to be worked out.

Page 2, Sent. 5 DCA did not mention anything of this nature.

Eng. Kabir suggested to have a unlform salary scale for the Field staff.

The issue was discussed and it was felt that the accountants and project managers of the agencies running veterinary activities should get together and discuss the standardization of the salaries. A meeting in this regard was scheduled for 21 st July at $2.00 \mathrm{~mm}$ at the DCA office. Participants of the meeting would be as follows:-

Dr. Tino Henecken and Dr. Hal imi from DCA, Mr. Qaderdan from ARC, Mr. Safi from ADF, Dr. Ghafoor and Mr. Almad Farid from GAF, Dr. Kazim Bashir Almed from PRB and Eng.
Fomat from ADA.

115. Announcements

UNDP announced that final reports for veterinary projects are due and appealed to the NCOS to submit their final reports of the projects as soon as possible in order to mable UNDP to transfer their remaining installments. The problem of obtaining reports from some of the field units was also mentioned by some NGOs, to this regard UNDP suggested to some how arrange and collect the information as soon as possible.

ThW Board of Directors and Managenent of GAF has appointed Mr. Ghafoor $\mathrm{i}$ as veterinary cordinator based on his professional qualification, outstandlng managerial skills invesied in the programe. The chairman and the particlpants congratulated Dr. Ghafoor Han on his new assignment and wished him success.

IV. Update on Veterinary Services by NGOS

As the topic was not clear, it could not be discussed during the meeting.

v. Estabilishment of Field Offices - by FAO

FAO plans to open five regional offices in the following provinclal centers inside Arghanistan: Khost, Mazar-e-Sharif, Kandahar, Jalalabad and Herat clty.

Ois regional officer and one monitor will be stationed in each office.

The Klosit office has already been established, Dr. Ibrahlmi and Dr. Amin are assigned thare. The opening of Jalalabad office is underway, hopefully it will be established 
The Khost office wlll cover vet: activities of Khost, Logar, Gardéz, Paktika, Ghazni provinces and southern Kabul (Charasiab).

The Kandahar offlce currently based at Quetta will cover Kandahar, Zabul, Helmarid, NImroz and Farah provinces.

The Jalalabad offlce will cover, Nanagarhar, Kunar, Laghman, Kabul, Kapisa, Parkal! provinces. As the Mazar offlce is not yet functioning, Baghlan, Qundos and Talihal provinces will also be covered by the Jalalabad office.

VI "Vaccine Provision by FAO

FAO will provide vaccines locally in Pakistan for the initial phase, as it is difficii to order vaccines from abroad because of shortage of time. It was proposed that $1 \mathrm{~h}$. study must be conducted to evaluate the potency and antibody level of the vacciint: before they are supplied to the NGOS. Past experlence shows that some of the vacoiris:. supplied by the NGOs were not effective.

MADERA announced that they have ordered some vaccines from Turkey and have b.... received. MADERA also $\mathrm{placed}$ an order with VRI Lahore, the shipment received froii :ilil Lahore contained some expired batches. MADERA proposed that NGOs should dilectly $i_{1}$, the vaccines from the institutions producing vaccines rather than using the se: of the distributors.

FAO suggested NGOs, to advise field offices to keep vaccines in cool, dry and : i:: places. Exposing vaccines to high temperatures is a matter of great concern.

VII Any other business

It was proposed that ACBAR should contact NRC and inquire about its veteili,i. programe in khost in order to get the activities coordinated and know the byje: activity NRC is doing.

ADA is urgently in need of two veterinary doctors willing to work in Gizab ind buli .... Districts of Urozgan province. Salaries are negotiable.

Next meeting would be held on July, 9 at $8: 30^{\circ}$ hrs at the ACBAR office.

\section{Participants:}

- Dr. Hussaini

- Abdullah Qaderdan

- Dr. Tino Hennecken

(CHAIPMAN) GAF - Eng. Esmat

ARC - Saf $\mathrm{i}$

DCA - M. Halimi

FA.O - Dr. Ghulam Saeed

PRB - M. A. Rashid

UNDP - Eng. Kabir

ACBAR
ADA

ADF

DCA

MADERA

RAFA.

PRE
- Dr. Nasseri A.A.

- Naqib Atmed Noory 


\section{A C B A R \\ VETERINARY SUB-COMMITIEE MEETING \\ TUESDAY 9 AUGUST, 1994}

\section{Approval of Agenda}

The Agenda was approved.

II. Minutes of the previous meeting (July 19, 1994)

The minutes were approved.

III. Announcements

FAO wlll distribute vaccines to five zonal field offices inside Afghanistan for subsequent distribution to the fleld units. The vaccines are expected to reach soon and distribution will start in mid August, 1994.

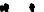

GAF got reports from Alisher distrlct of the outbreak of black leg disease. It was suggested that FAO should contact its field office in khost and instruct the staff to verify GAF's report as soon as possible.

FRB established a field offlce in khost. One monitor and one storekeeper are assigned for the office.

DCA is in the process of opening its fleld office in Jalalabad. One monitor, one storekeeper and one chowkidar will be based at thls office.

ADF opened a fleld office in Jalalabad on Chaparhar Road near Angoor Bagh.

MADERA has recelved 150,000 doses of Agalactia vaccine from Turkey. The vaccination campaign has already started in Kunar province. Vaccination is expected to be completed within 20 days.

MADERA has also received some Foot and Mouth Disease Vaccine.

DCA announced the next paravet course to be conducted for Paravets in Peshawar in January, 95. Application forms were distributed to the NGOS at the meeting.

IV. Update on Field Staff Salary Standardization

The agencies presented the field staff salary skilis as follows:

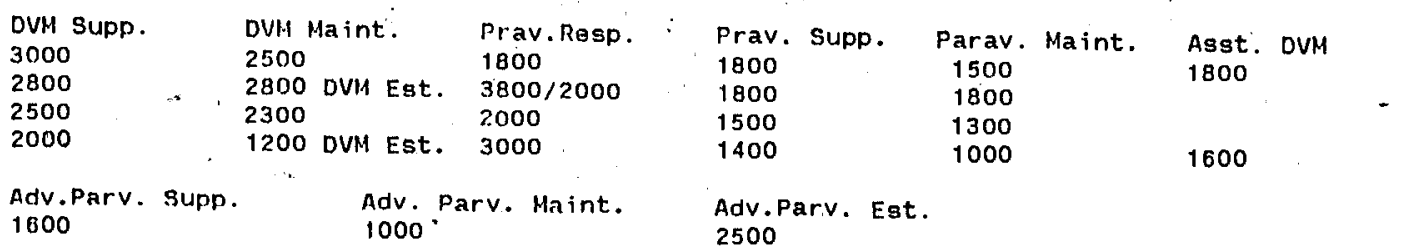

DVM are paid RS. 160 for equipment purchase. Advance paravets and Asst. DVM are pald 80 Rs. for this purpose. Clinlc reponsible (s) are paid 500 extra than the
salary allocated. 
V. Update by NPO on its veterinary activities in Khost

NPO established two veterinary clinics, one in Khost city and one in Gardez town on $26 \mathrm{April}$ and 15th May, 1994. Till June 26 the veterinary services and treatments were provided to some 150 animals in the said clinlcs and 500 chicks have been vaccinated." About 100 farmers werc trained in basics of animal husbandry. and veterinary. The clinics have mobile teams who' vislts remote villages. The medicines are sold at a subsidized prices.

Partlcipants present at the meeting suggested to NPO it could have been better if: NPO could have consulted with the ACBAR veterinary sub conmittee prior to the opening clinics in Khost and Gardez. The veterinary subcommittee is coordinating the activities of all the NGOs working in this; sector and thus the problem of overlapping is solved through this cormittee. The establishment of NPUS clinic is a duplication and overlapping of similar activities as GAF and PRB are already working ii, these areas since a long time.

The commitee suggested that NPO should move its activities to scme other places where no veterlnary clinic exist or change the type of activit; they are doing at the same location. The representative was requested $1:$ contact the veterinary cormittee of ACBAR to resolve the issue.

Technical staff evaluation was also a point of discussion and it was recommended if NPO could get the certification of the professional stafi hired by them from the commlttee appointed by the member NGOs of the silh cormittee for this purpose.

The medicines sold at a subsidized price by NPO was also a matter of concern, as the medicines are sold at $100 \%$ price by the NGOs.

Any other business

a) AWRC Vet. Activities

AWRC distributes chicks to refugees in Kacha Gary, Peshawar. The: programe is for 9 months.

MADERA proposed formation of vaccination sub-comnittee. In order to have effective vaccination, the committee has to evaluate the needs and time of vaccination which will be more effective than the 12 monthis contimuous vaccination.

Next meeting would be held on July, 30 at $8: 30$ hrs at the ACBAR office.

\section{Participants:}

- Dr. Hussaini

- Mr. S. Safi

\section{(CHAIPMAN) GAF}

ADF

- Mr. Hajl Khalid Rasheed

- Dr. Parwin Arif

- Dr. M. Kazem

- Eng. M. Alam

- Dr. Ebrahimi

- Naqit Ahmed Noory

\section{ADF}

AWRC

PRB

NPO

FAO

ACBAR
- Abdul lah Qaderdan

- Anber Gul

- M. V. Dool

- Dr. M. S. Tahir

- Dr. Nasseri A.A.

- Dr. Sediqullah

- Di. Ghafoor
ARC

ADF

DCA

MADERA

UNDP

FAO

GAF 


\section{$A C B A R$ \\ VETERINARY SUB-COMMITTEE MEETING \\ TUESDAY 30 AUGUST, 1994}

I. Approval of the agenda and the minutes of the last meeting

The minutes and the agenda were approved.

The table of Salary standardization will be studied by NGOs, corrections would be submitted to ACBAR, if any.

\section{Announcements}

DCA is concerned over hiring of a staff member of DCA's Quetta office by FAO without the official consent of the DCA.

ARC will not be able to continue the veterinary services due the fundinc cuts and thus will not be attending future veterinary meetings. ARC used to work in Malistan and Jaghori districts of Ghazni.

The chairman proposed if FAO facilitate the take over of the mentionec clinics by another NGO.

FAO hàs received the supply of vaccines from Quetta, and will be transporting to FAO regional offices inside Afghanistan for distributior to the field units.

MADERA performed the Agalactia vaccination campaign in Kunar province. Vaccination in Laghman is postponed for a suitable time because of recent unrest in the province.

RAFA prepared and published a book for Basic veterinary Education for Rural women. Interested agencies are welcome to obtain a copy of the publication.

III Supply status of vaccines and medicines to the field units by NGos.

ADF pays field staff salaries in cash, the field staff themselves procure the required medicines of the VFUs from the local traders.

GAF purchased some medicines from Lahore and Peshawar (worth of 7 lack) which will be sent to the field units.

DCA has supplied the medicines to more than $70 \%$ of VFUs till the end of the year. The medicines to Bamian, Urozgan, Helmand and Kandahar has tc be supplied soon.

FAO reported that some veterinary medicines are available in Herat anc Jalalabad cities, but did not have information on the other regions.

DCA recommended that the quality of medicines should be under the surveillance of the concerned organizations. The chairman supported the idea and said with the introduction of private business to supply veterinary medicines inside Afghanistan. There is a possibility that fake medicines may find it's way to the local markets.

The committee for Vaccination Technical Guidelines, was asked to come ur with the final recommendations regarding vaccination schedule on zona] bases for the commonly available vaccines.

The question of NPO veterinary activities in Khost and Gardez was raised, the participants wanted if there is any response from NPO ir this regard. Unfortunately due to the absence of NPOs, representative 
the issue could not be discussed further. It was suggested that ACBAF should write a letter to NPO and ask its response in this regard.

VI. Any other business

None

\section{Participants:}

- Dr. Hussaini

- Dr. A. Ghafoor

- Mr. S. Safi

- Anber Gul

$\begin{array}{ll}\text { (CHAIRMAN) } & \text { GAF } \\ & \text { GAF } \\ & \text { ADF } \\ & \text { ADF } \\ & \text { DCA } \\ \text { Den } & \text { DCA } \\ & \text { MADERA } \\ & \text { UNDP/OPS } \\ & \text { RAFA } \\ & \text { ACBAR }\end{array}$

- Dr. Rahmatullah

- Dr. Tino Hennecken

- Dr. M. S. Tahir

- Dr. Nasseri A.A.

- M. Asif Rashid

- Naqib Ahmed Noory

ACBAR 


\section{A $C$ B A R \\ VETERINARY SUB-COMMITTEE MEETING \\ 18 OCTOBER, 1994}

By Naqib A. Noory

I. Approval of the minutes of the last meeting

Following corrections were made to the minutes:

- Page 1, Under iteln III, PRB's recommendation is not only for the supply of medicines but. it should also include other support supplies in particular the bicycles. PRB also emphasized on the field staff salaries were paid in cash, the salaries did not include the Rs.30 and Rs. 20 DSA for DVMs and "paravets respectively which is paid based on the number of working days, after the progress report is received by the office.

- Page 3 sentence 3, DCA inquired about the status of BVW manual, not women manual as reported in the last minutes.

After additions/correction the minutes and agenda were then app:oved.

\section{I.T. Tinnouncements}

Fro amnounced that the second batch of väccines will be arriving from Quetta at the end of october. FAO asked NGOs that their regional offices and as well the VFUs should be ready to receive the vaccires. Permit arrangements have already been made to transport. the vaccines.

DCA informed FAO, that they only need Anthrax vaccines and has other vaccines available. on stock. As some of the DCA allocated vaccines will be surplus, FAO asked NGOs to submit their request so that the vaccines could be distributed.

PIRB inquired about provision of vaccines from FAO Mazar office. FAO in response said chat due to transportation problems, they have not been able to transport the allocated vaccines yet. Efforts were made to charter the UN plane for the shipment of vaccines to Mazare Sharif, but due to the engagement of UN planes in other activities of important nature this has not been materialized. Only small quantity of vaccines have been sent to Mazar using the UN planes. NGOS willing to transport the vaccines to Mazar frcil Peshawar will be provided vaciines in peshawar.

The chairman urged FAO monitors and as well the. NGOs to take effective measures as to prevent the possibility of resale of vaccines to the black market. Following a lengthy discussion, it was recommendery that VFUs be asked to keep the empty bottles of the vactines, which would be then condemned by the FAO or NGOs monj.tors. Also the batch number of vaccines issues to NGOs and to the VFUs should properly be recorded. 
40 
Dr. Barker encouraged the steps of the members of the vetcrinary sub-committee regarding the issue of regionalization and Consolidation of activities of NGOs, despite the problems mentioned in a letter to him by the concerned NGOs in this regard.

Regarding 1 ist of paravets and DVMs, FAO has requested ali NGOs to send omplete list of their personnel as form where they are and where they are currently working. This may help the reorganization and reshuffling of field staff among the NGOs with the preference of assigning the staff to their native home ristricts in order to make it easy for them to establish their practices in order to achieve sustainability. - III. Future plans with regards to nnimal Husbandiry and

Dr. Barker briefly talked on the topic and said that he has not yet spent enough time in Afghanistan. He said that he will need a study and discussions with experienced farmers. He will be going to the South and North where he will conduct surveys and will get the feel of the farmers about the animal production. The results of the survey will be discussed with the lJGOs working in the veterinary field.

Dr. Barker also informed the meeting that fro will have a consultancy to see and compile the documents available on animal husbandry. The survey on animal husbandry. will be spread to other
regions next year.

FAO will be employing a woman Veterinarian who will be training some women BVWs and who will also focus on poultry farms.

In conclusion, Dr. Barker sajd that he will. consult with veterinarians who had experience in the field of animal husbandry. Once these process are completed, FAO will focus on animal husbandry, housing, breeding, nutrition whicli presently lacks and will find out from the farmers the various aspects of the programme. FAO will then set up an experiment in villages and
would see if anything could be developed.

DCA pointed: out that FAO appointed a Female veterinarian ahd a medical doctor last year, but nobody knows what have they dorfe.

In response. FAO said that they were mainly working on polftry distribution in refugee camps and also some places in Afghanistan. As the veterinary programme has been transferred to FAO, UNDP will keep the two ladies who will generally concentrate on women programmes, eg. income generation, poultry farms and education, aimed at improving the lives of women.

The chairman said that the vet. sub-committee asked UNDP that the women participate in the sectoral meetings. Unfortunately this has not been materialized. On the same notice the request is renewed to the NGOs and the current UNDP/OPS veterinarians to participate
in the meetings. 


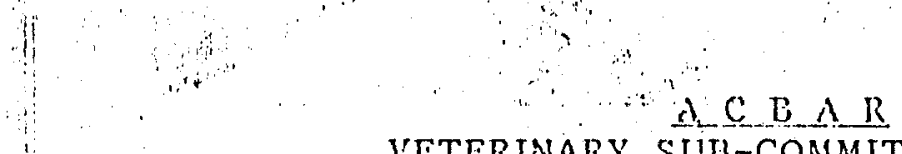

VETERINARY SUB-COMMITTEE MEETING

15 November, 1994

By Naqib A. Noory

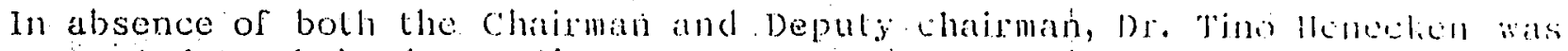
requested to chair the mecting.

I. Approval of agenda and the minutes of the last meeting The agenda and millules of the hat meeling were approved.

- II. Announcemerits

A-AID doesn't work in velerinary, but would like lo get informalion an velerinary services provided by NGos in Baclaklislinl.

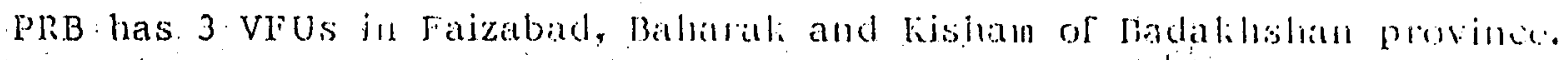

DCA has conducled a LIVESTOCK MORTALTTY IN AFGHANISTAN. The aIM af Hic survey was to analyze the economic benerit to the livestok by pentinge veterinary services. The surtey seport js enclosed to the minute:

III. Take over issue of Malistan and Jaghori VFUs (GRP's interest)

ARC notified ACUAR that they will be discontinuing veterinaty suiveres in the

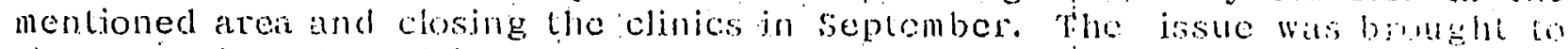
the attention of pallicipants, especially l Fo for possible support and continuit:

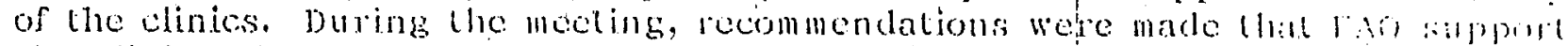

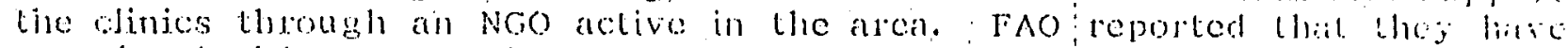

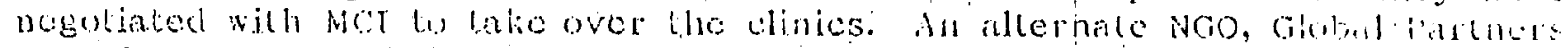
was also recommended.

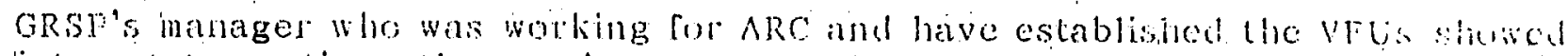
interest to continue the services.

GRSP said that based on the Board of vienna, ARC decided fo lisconibus the

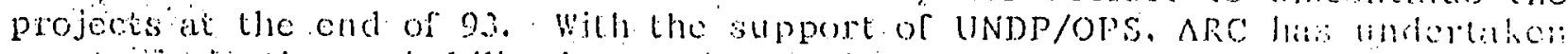

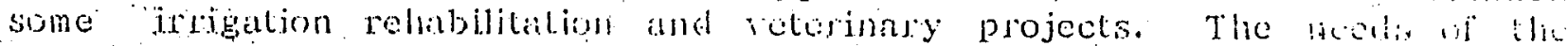

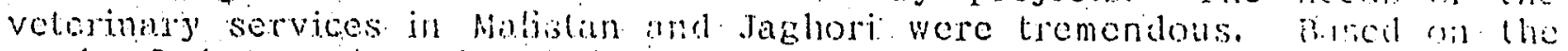

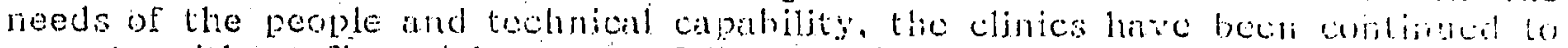

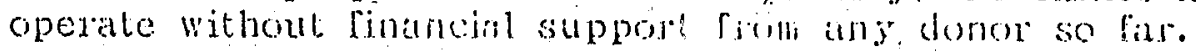

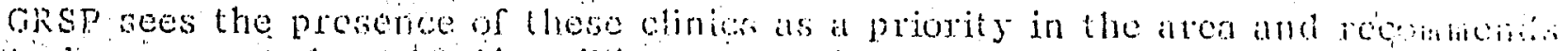

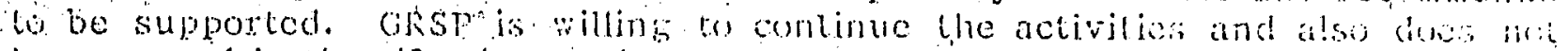

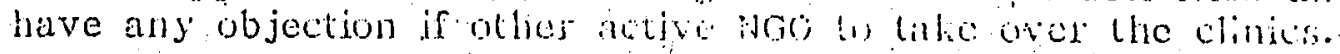

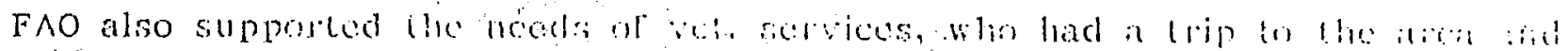

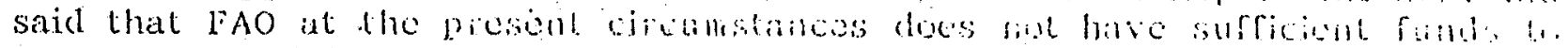

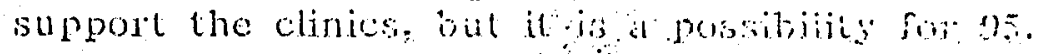

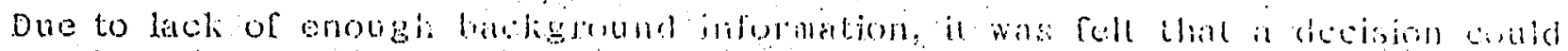

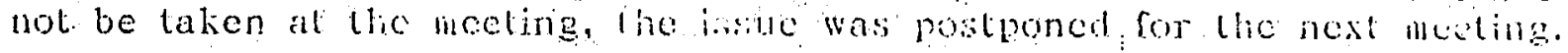

IV. "Monitoring issue a) vils

b) BVWs

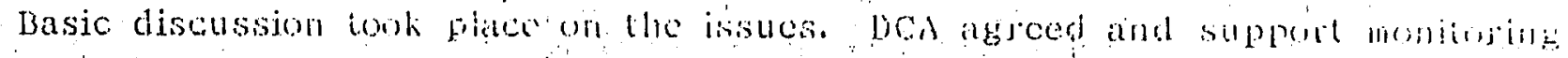


or vet. anctivities, but said that it will be difficult for the NGOs to conduct monitoring where very less funds are available.

Due wo the fact that the chairman was well aware of the issues, who was not

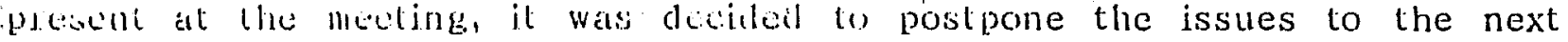
III'Ling.

\section{Any other business}

DCA asked, whether the Noos pry tiver" star inside Afghanistan in Rupees or Afghinis.

After reports of each agency at the meding, it was known that most agencies pay in kinal of paty in Rupees. A need of a unified policy was foll, it was suggested that this issuc also be discussed agalin at the next meeting.

The aeral velerinary sub-Commille Meeting would be held on:-

\section{DECEMBER 6, 1994 \\ AT 09:00 HRS \\ ACBAR OFFICE}

The contative agenda of the meeting would be as follows:-

1. Approval of agenda and the minutes of the last meeting.

I1. Annouricements.

IIt. Tatie over issue of Jaghori and Malistan. VFUs/Clinics

IV. Wonitoring of VFU and RVWs

$\because$ Unified policy log. salary pryment, either in Rupees or afglianis.

please hote that mo further reminder will bo sent for the meeting. Any additional point is could be atlded (o) the agenda during the meeting.

Hat ding ho further business, the inciling was adjourned.

\section{Participants:}

- Dre rino Heneclien.

- i. ?inlind

- Dir sinafoor

Ehis sullian

- Ghulam Sacd.

$\checkmark$ Niv. Silfi

- Di: Abclul Qador Samsor:

- M. v. d Dool

- Sieliqullah

- Nocis Aghia

DCA

$A-A I D$

GAF

RATA

MADERA

$\triangle D F$

DCA

$\mathrm{DCA}$

FAO

GRSP

- Nacib Ahnod Nory

$A C B A R$ 


\section{5}

ACBAR

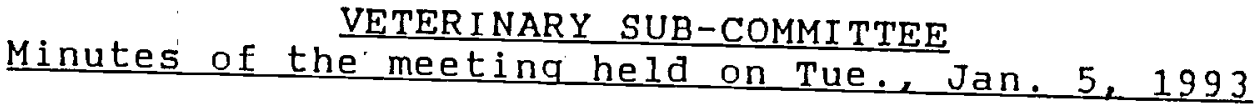

I. Minutes of the previous meeting:

a. Name of the attendants from DCA was missed (Dr. Qasem).

II. Announcements:

UNDP said that since the program has been getting closer to its end (by end of June 93), the matter of frivatization of medicines supply should be discussed. How to do this is an issue that agencies should think about.

III. Letter of the Sub-committee to concerned agencies: In the previous meeting it was stated that some agencies have been introducing poultry into Afghanistan without chickens. This has caused spread of some disease even in local be sent out to all concerned suggested that a letter should problems in the future and hagencies to try and avoid such Sub-committee prior to distrib full consultation with the animals into Afghanistan. The oftion of poulty or other drafted by the chairman The letter in this regard was distributed to all concerned A copy of this letter will be

IV. Results of Negotiations with David Lockwood:

ACBAR is trying to arrange a meeting with David Lockwood regarding the future of UNDP funded projects in Afghanistan.

V. Evaluation Report on Pregnancy Test Workshop:

3 courses "Pregnancy Testing in Cows" were held by UNDP together with CRAA in Nangarhar Province. Each course was 2
weeks.

37 veterinarians from NGOs, Ministry of Agriculture and FAOmazar-i-Sharif attended the course. All arrangements were made by CRAA with the financilal assistance of UNDP. WNDP course was evaluateoretical and practical outcome of the the arrangements taken for good". CRAA was appreciated for

VI. UNDP Flip Charts: Woodford or Dr. Sherman of IMC should be invited for this should be called to most of the field vets, if possible, possible in a month time (he seminar. This would be UNDP - Peshawar will time (beginning of February, 1993). fix a date and will or Dr. Sherman to meeting. 
UNDP said that for the sustainability of the vet programs the main objective is to train more BVWs. According to the program 420 BVWs were "supposed.to be trained which was not achieved 100 percent. Evaluations showed that some BVWs were good and some were: not effective. UNDP said that the following might be some of the reasons:

a) Poor "selection of the trainees.

b) Nat enough medicine was given them by the clinics (vet.).

c) Location of the training. Those who received training in Peshawar seemed to perform better than those who received training inside Afghanistan.

d) Training: Some trainers had good knowledge but a poor ability to transfer it to others.

It was also questioned:

i) How many BVWs are active?

i i) How many more should be trained?

CRAA conducted a refresher course for BVWs in shisham.Bagh. 21 others were also selected for the next course which will start in a day or two.

\section{The attendants:}

Dr. Neil Chesterton (chairman)

Dr. Sayed Aqa

Dr. Mehraban

Dr. S. Qasem Alemzada

Dr. Housaini

Dr. Sayed Mohammad, D. Zaker

Safi

Khalil ur Rahman

The agenda for the next meeting which will be held Tuesday, January 19,1993 will be as follows:

I. Minutes of the previous meeting.

II. Announcements.

III. Election of. Chairman and Deputy Chairman.

IV. Report of UNDP -NGO monitoring team.

V. Medicine supply- should be provatized?

VI. Results of negotiations with David Lockwood (if takes place).

VII. Evaluation of BVWs.

VIII. Any other business

- Eixing date with Dr. Woodford/Dr. Sherman

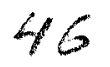




\section{$\triangle C B A R$ \\ VETER INIAR $Y$ SUB-COMIITTERE}

Minutes of the meeting hela on piresdry, Jiil 12, a?

I. Minutes of the previous meeting:

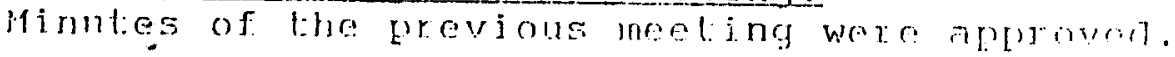

IT. Tlection of the new chairman and peputy:

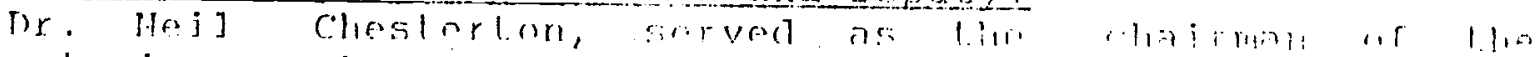

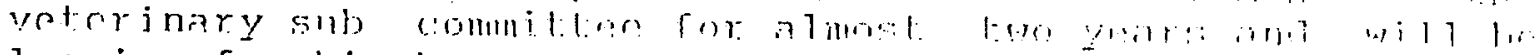

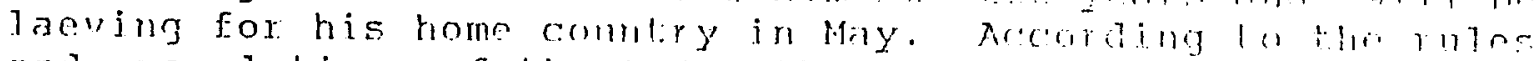

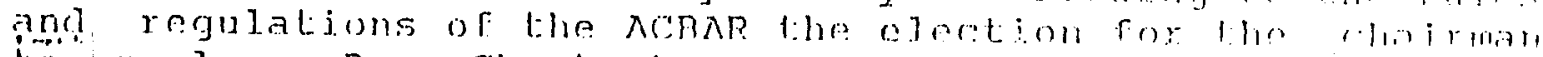

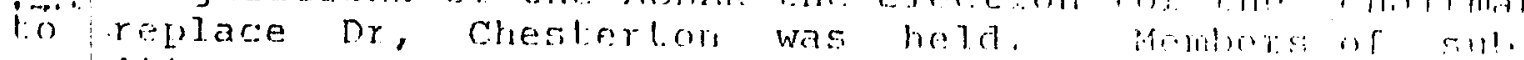

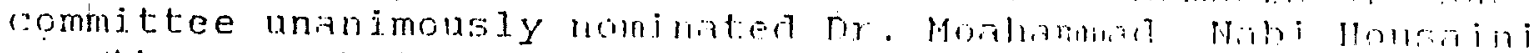

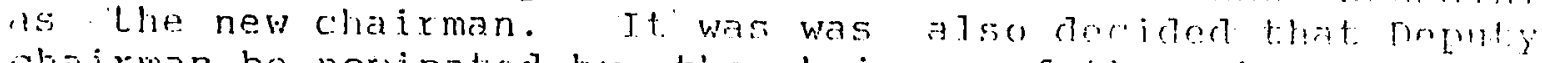

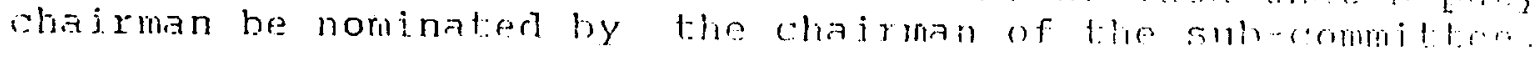

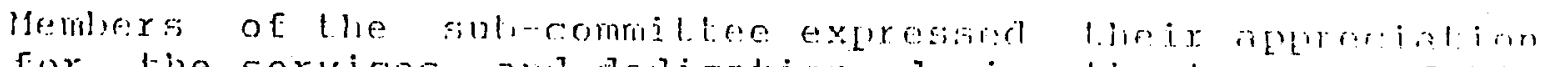

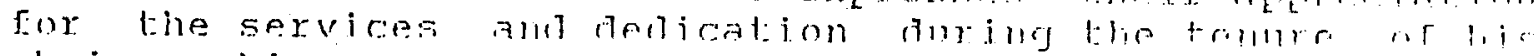
chnirmanship.

III. URDe Monitoring of BVWs Proirams:

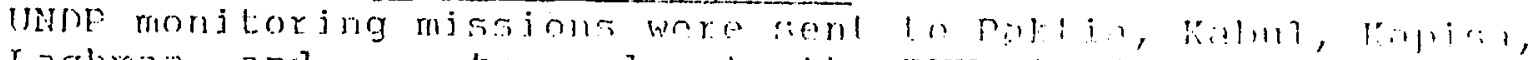

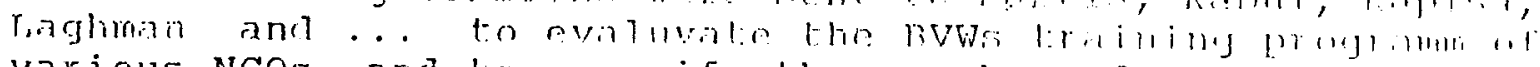

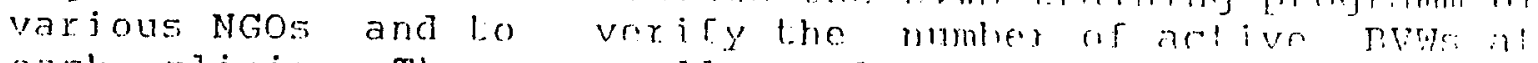

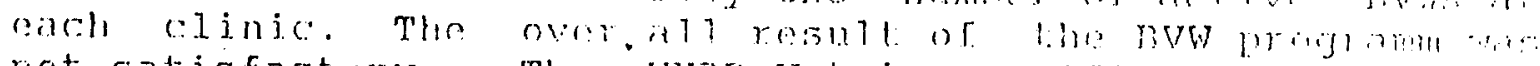

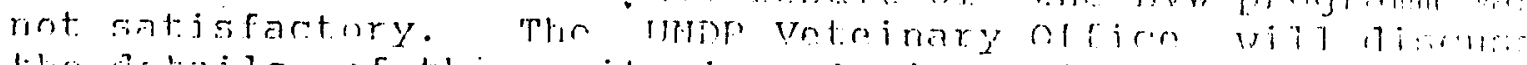

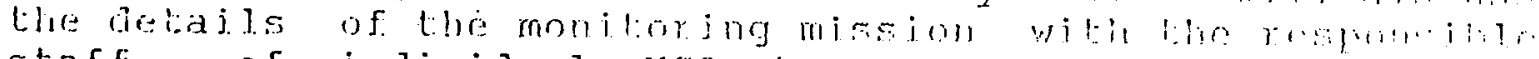

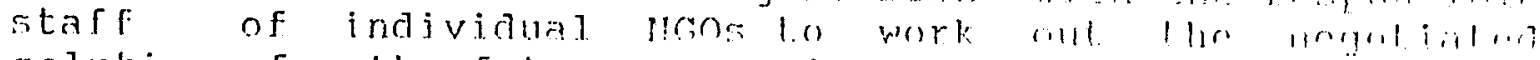
solutions for thr rutura operations.

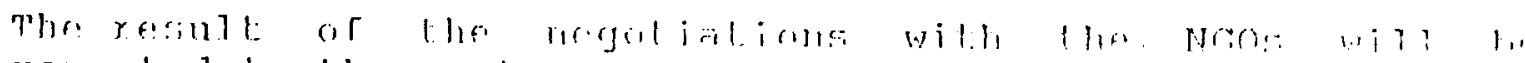

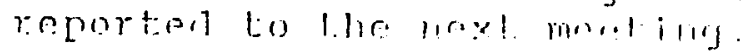

TV. Rerulte of negotialions yiln David lockynor!:

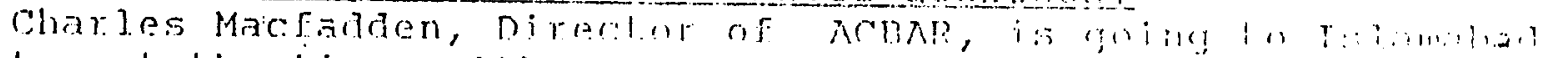

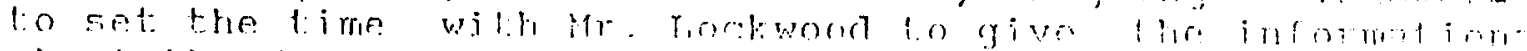

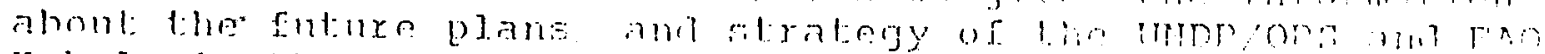
[a!ml, in line velerimary sorelor.

V. Determination of late with Dr. Wondford:

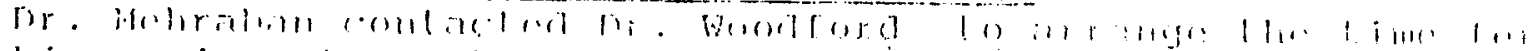

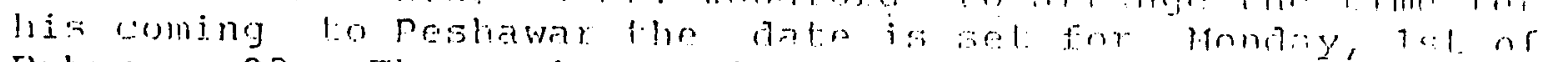

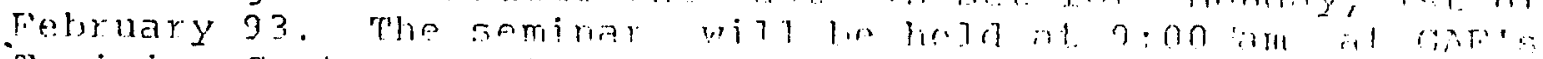

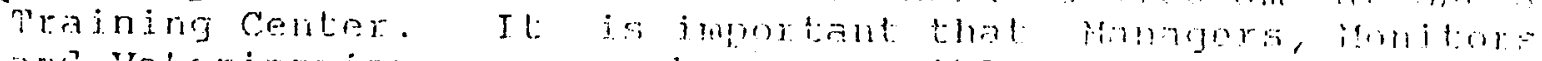

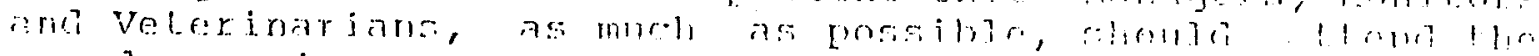
menthy siminis.

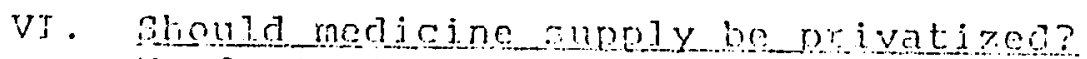

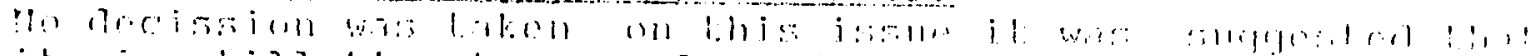

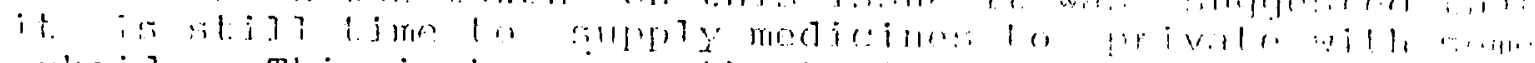

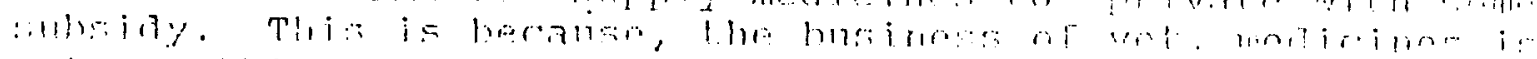

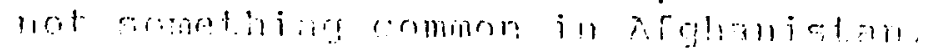




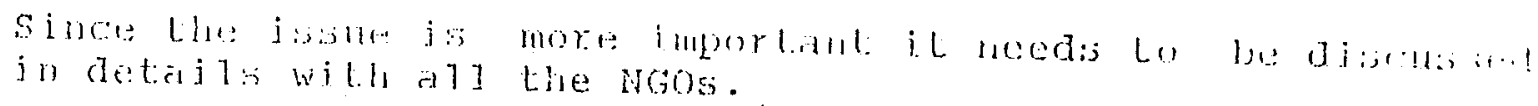

VII. Any other: business:

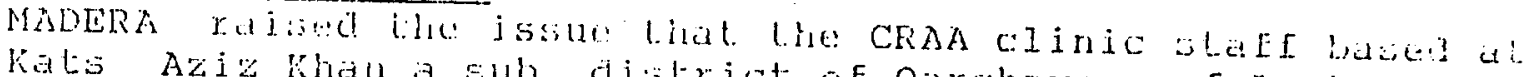
Kats Aaiz Chan a Eub aistriet of Qarghayee of Laghinin, i.:

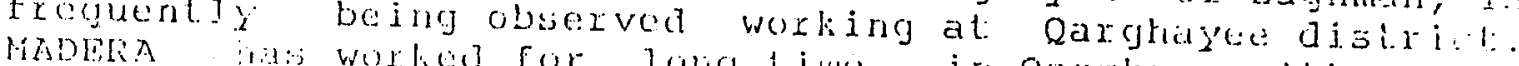

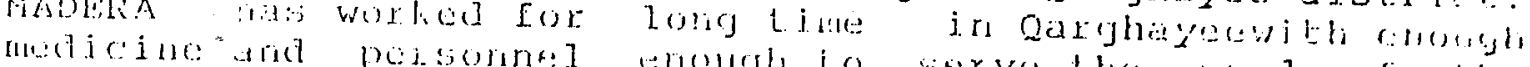

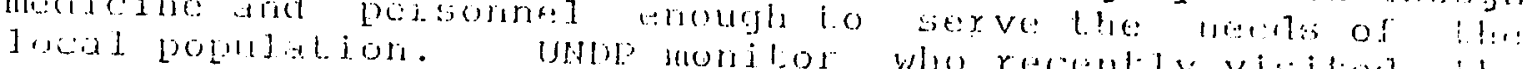

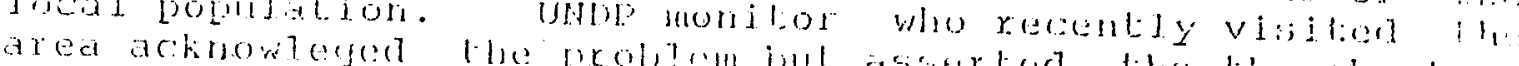

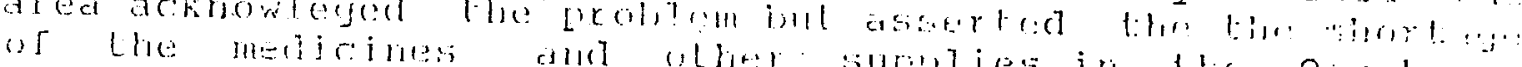

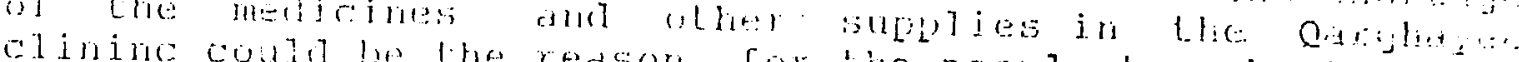

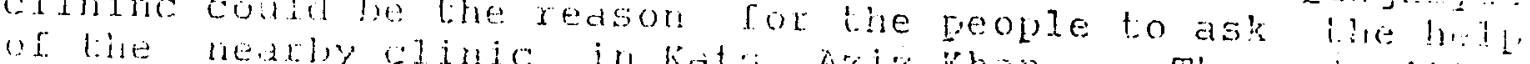

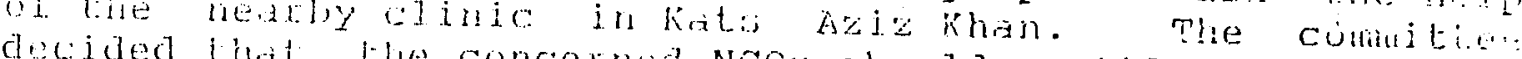

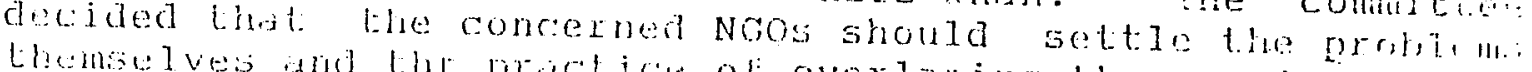

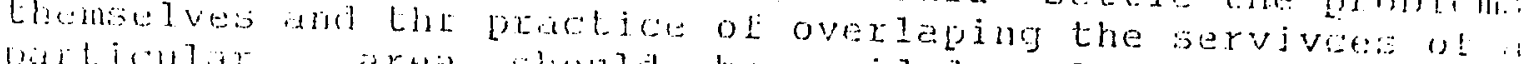
baticular area sholde be avoided unless there is

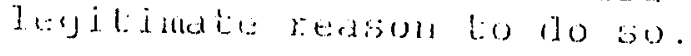

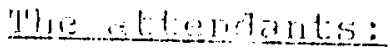

Me Hoil Cluestexlon (chairnan)

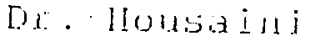

[ix . Gayed Ara

Mr. Safi.

D). Gh. Sat?ial

Di. . Bi isluj. li ial

Dr. Mehrabaridor . Ehtahini/ Dr. Nasseri

DL . Sayed loghl/ Dr. Diud Sliah

[?]. S. Oasen Alemarta

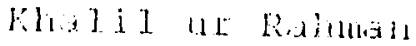

(OHIDEV

IRC

$A R C$

MADFR?

CRì?

PRS

UNDT:

GAF

DCA

ACBAR

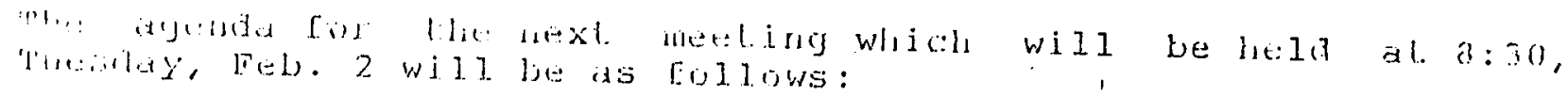

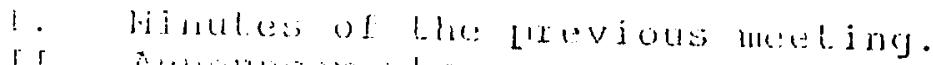

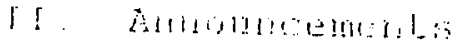

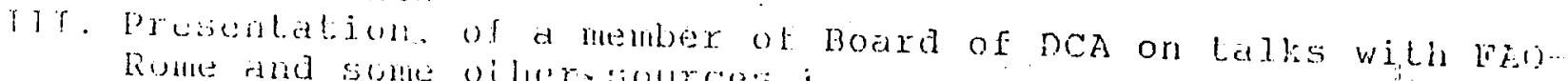

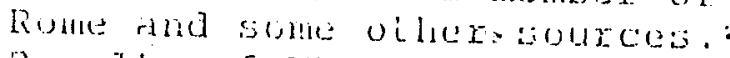

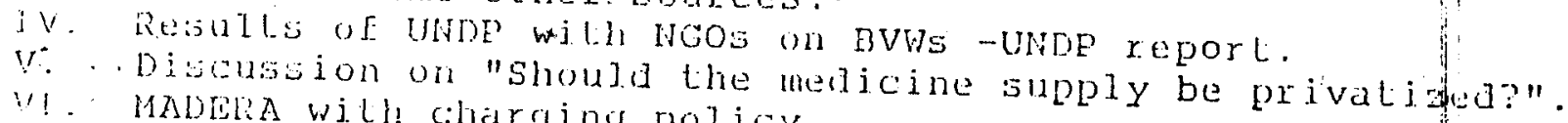

"! MADERA wj.th chargjng policy

A high lovel represcalative of partiripates in line meeting to i 5 silus

Lie: ayerfiey and discuss pol i : $y$ 


\title{
The changes to the previous minutes were underlined here with
}

\author{
$A C: B A R$ \\ VETER INAFY SUE-CDMMITTEE \\ Minutes af the meeting held on Tue a fob. 29
}

\section{Minutes of the previous meeting:}

Minutes of the previous meeting were approved. $\because$.

\section{Announcements:}

A. DEA reported that their field staf has observed einge af Fabies in shege and gote in Hesar al distriet of Nangarhar . For confirmation of the di agnosis, sanples will be sent to Lafrome for taboratory exaninations.

E. Dr. Dennig, the guest professor to one of Bar a curses, has expressed his willingness to provide foronth refresher training on parasitio diseases af livestant: to the field veterinarians of NGOs. The Sub-ommittes members sad that field staff of NoOs may not have time to attend surh longuterm courses. In stead his expertise coubd be lised better in an a ademic conter e.g. Fabul University. The Sub tommit tee suggested to set-up a committee to priarities the future trainjo

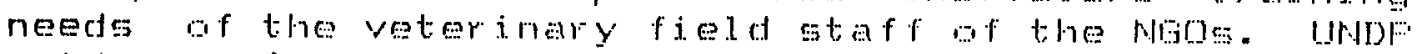
sajd thet epdomiology and methods of disease investightion may be the major topi tos to be considered for the futwore.

E. Due to sucden ohanges in GAF administration, Dr. M. Nato Housaini was apponted as the bordinator ror Veterinary Frograms of that agency.

D. The cheirman requested Dr. Halimi of Dia to contimue his tasti as the deputy ohaiman of the Veterinary sub committee: Dr. Halimi agreed to the request.

E. Dr. John Woodford stated that there are evidences that FAO will agree to continue funding the veterinary

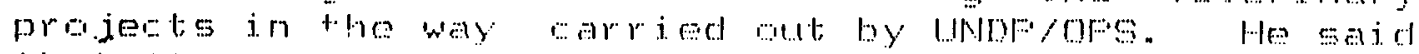
that it tal:es a year or more for any UN adency from the stage of decision to the stage of implenentation.

F. Dr. Jahn Woodford and his a lleagues were thanked for good presentations given about the fi.p obarts.

III. Presentation of DEA member of board on talks with FAQ authorities in Pome:

Dr. Bram Sohreuder, DeA member of boded, made a vigit wf Fo in Fome. He talled to some FAO officials about the future policy of this agency towarde the bios running veterinary programs presently funded by uNDF/ows. Dr. Gobreucer was told that in May 93 a misesion may come to condur survey. The survey will be completed within 3 month with the angultation af UNDF. Fepot ar the survey will probably be 
completed by July or pugust and will be submitted to the author it jes. Agencies were requested to manage their views

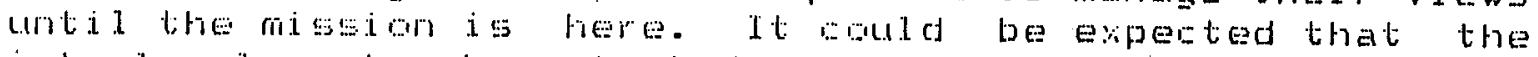
actual plan to be started frorn the beginning of gat. Acording to the rew poliey, new projects will be furded up to The supervising agency (umbrella) will be responsible for prourement and trangpotation serviaes. A similar saheme is applied by FAOANDF in their present agrioultural projects. Dr. Sohruder added that this paliay will be applied to the programes implemented in the southerm movinges af Arghanistar corass-barder?. With the transition of. the progrommes to inside Afghanistan, therr might be cherrges. The prograll in the North which has bes

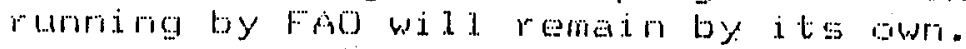

UNDF was very optimjetio about the Gontinuation of funds far this sector" The projects may be funded for the last months of 93. Agenojes an start wort: on their porposals in thi $\leq$ regard.

Dr. John Wowdford sajd that for him dat the teghnial level) it is difficut to say about the exact policy beyond June 93. The Frograin Manager is worling on this issue.

IV. Results of UNDP discussions with individual NGOs on EVWs:

As il: was mentioned in the previous meeting, UNDF-Feshawar sent monitoring teans inside Afghanistan to evaluate the autcome of EVW programs arred out be UNDF funded prajects.

UNDF sad when the issolu was distusged with each NGO, it was found that the main probem was with the selection of individuals to be trained as EVW. Another reason was the joatoild ty or unwillingness af the staff in-aharge af the

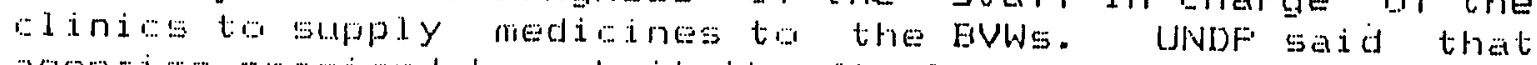
agenejes promised to submit the final evaluatian report in a morti. The next evaluation will be done end of February or beginning of lareh.

UNDFFFeshaw sajd that mest of the EVWe Trainees selected were literate in some caseg even 12th grade passed as

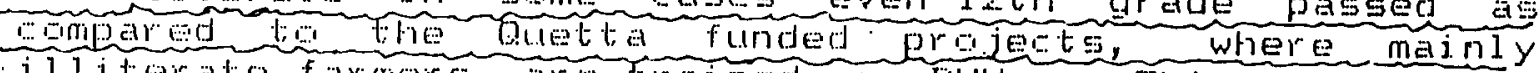
illiterate farmers are trained as BVWs. This shows high peraentage sumess under Festiawar program. UNDF-Feshawar

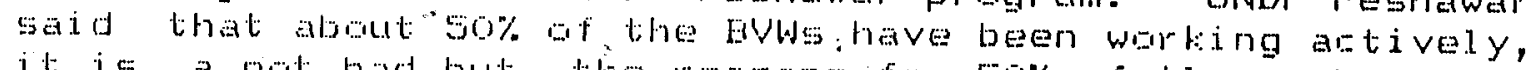
jt is a not bad but tife reasons for $50 \%$ failure should be Qval liated.

DOA sajd that it is easy to tall about improvement af EVWs. In fact, there are some problems which are stated belaw:

j. ) trut to return the maney

i.i. satety on way

i.i.j flutuation in exirange rate between Afghani andingtrupes. 


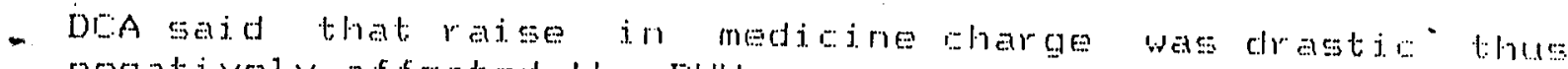
negatively affected the BVW programe.

V.: Privatization of medicine supply:

UNDF-ouetta seid thet the current ly twoprivete businesess

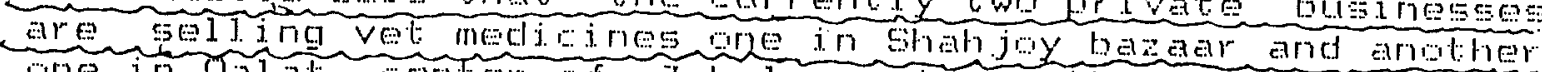

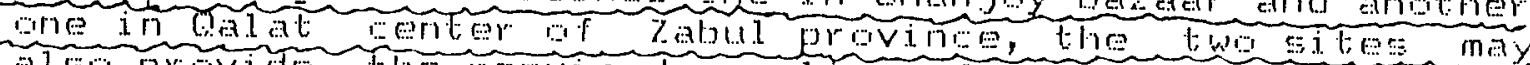

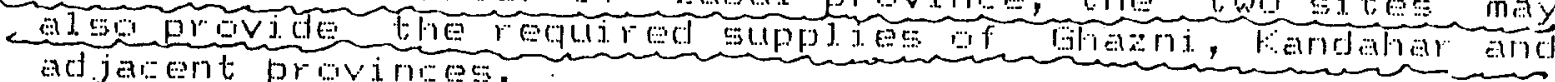
ad jacent provinises:

VI. Position of MADERA on Charqing Policy:

MADEFA sid that the ageney started warging of $90 \%$ wn

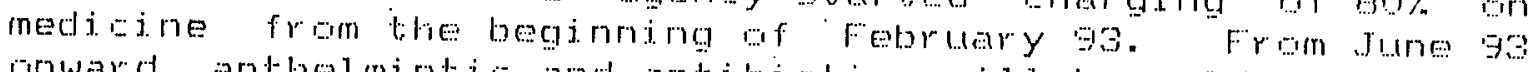
ornward, anthelmintio and antibiotio wi lo be sold at $100 \%$

of the purbhased pride

\section{The attendants:}

Housanini. chaj.rnan?

J. Myerse Dr. Sayed Aga

G. Wassink/M. Ha i.mj/ B. Gohreuder/Alemada

J. Wordford/Gifi/ Bashir Ahmad

Mehraban/ Nasseri./Sediculu. 1.ah

Git. Gaeed

Nej. J. Chestertin.

5. Ahmadza i

A.jmal. Shirzay

M. Юazem

Sayed Mothd

Khal il ur Fathon

GAF

ArE:

DI:A

UNDF / OUEE.

UNDF/Fesh,

MADEFA

COIDEV

CFAA

$A F E:$

FFE

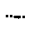

ATEAR: 
$-$ 
Minutes of the meeting he]d on Tucsday Fehruary 16, 1993

I. Minutes of the previous meeting

Due to some changes in the minutes, it was requested that member . should be re-typed and re-1istributed to the

\section{II . Announcements:}

MADERA reported cases of abortion in goats at $3-4$ months of

pregnancy in pashad district of Kunar the ralic of incicronco is about $80 \%$ of the total population. MADERA suspect that as the same episole tonk could bo dur to mineral deficiency year. Veterinary Research Institute the same location last. their advise by MADERA suggested that that wen asked for fetus should. be sent for gested that samples of the aborted facility. MADERA also ronfirmative diagrosis to the VRT on the bases of the seroleported the cases of pasteurelosis field laboratory among gological test they performed at their It was Narai, Kunar province.

It was mentioned that soasonal varerind, plourofneimonin, has been applied. Antibintics can save the affecter gnats but it can not prevnut atmrtion. cRAs said that this
disease has previnusly horn scon in kunar province. The participants of the sub committen decided follow the
measures:

a) Two sick animals should be brought to Peshawar for

b) At the field lovel MADERA can carry out the mineral
supplement trail

\section{II $\frac{\text { Results of MADERA and CRAA negotiations: }}{\text { The representative }}$}

position resentative of. MADERA stater that he is not in director of CRAA to discilss in this regard and asked the MADERA regarding the iscuss the mitter with the director of the Kats Aziz Khan clini of Qarghayed clinic of MADERA and

IV. UNDP on privatization of medicine supply

UNDP stated that they are in the process of preparing a

that the irafit will of medicine supply. It was promised comments. The purense of privatioation the mempers for avaliability of menicinn ingion Afohanistan was inclionted as a question regarding lhe ful:ure plon or to the field stafe whether they will be paid by the wene ar.
not. 
UNDP said they will pay salaries of the necessary field staff.

PRB stated there are some businessmen.. Interested in the supply of veterinary medicines from Tajikistan with low prices to all parts of the country. In ACBAR. Generad regarding lhoir plans for veterinary sector. rockwood stated that they have not. decided any

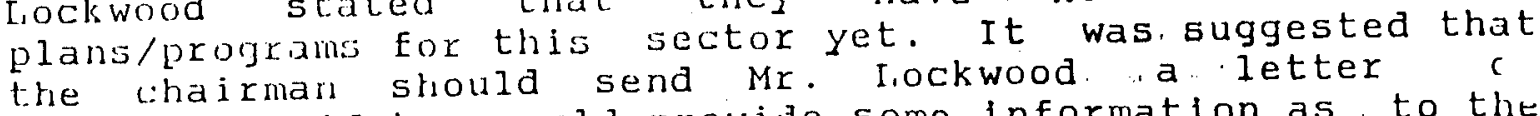
invitation if he coula provide some. Information as to the future operations of the veterinary projects.

Regaraing Dr. Demig's the visiting professor from Germany who is ready to come for six weeks refresher training in parasilology for the Eiela veterinarians the chairman suggested thit two/thrce agencies should come together and list priorities for the training.

VI. Any other business veterinary clinics in parwan province. It was declded that represcntatives of GAF, $\mathrm{PRB}$ and DCA should.visit the areä and relocate the clinics in appropriate positions. GAF is planning establishment of new Clinics in... Mogur, Zana Khan, Gilan, and Giro districts of Ghazni province.

\section{The participants:}

- Housaini (Chairman)

- Sayed Aga

- Sanaul Haq Ahmadzai

- Mohammad Kabir

- Moharmad Kazim

- M. Hali mi

- Ghulam Sayca

- Ghafoor Khan

- Sediqullah

- Mehraban

- Abdullah

- A. Ghafar

- Shafiq Ahmad
GAF

$A R C$

CRAA

PRB

PRB

$D C A$

MADERA

GAF

UNDP :

UNDP.

ARDA

GAC

ACBAR

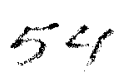

! : 


\title{
55
}

\author{
A C B A R \\ VETER INARY SUB-COMMI TTEE \\ Minutes of the meetimg held on Tuesday March $2 \times 93$
}

\section{Minutes of the previous meet ing:}

Approved.

\section{Announcements:}

MADERA field staff observed signs of a disease ifield symptoms Pasteurelinses) in Narai and Fashad. The samples were sent for examination to VRI. The serological test resulted negative.

I I . Discussion on the overlap problem among GAF, DCA and PRB in Parwan Province:

These 3 agencies have clinics in Jabal-u-Garaj and surrounding villages of the district. Acoording to the poliey set-up by the Vet'erinary Sub-committee, there should be anly ane agency per district. The agencies were astied negatiate in this regard and avoid overlap. The representatives of the agencies said that they will meet tamorraw to discusg; the problem. The result will be reparted to the next meeting.

IV. Results of talks with David Lockwood:

A letter was sent to David Lockwood to at tend one of the vet. Sub-committee meetings and highlight on future polioy of UN towards the contractor veterinary programs. No response was obtained. It was suggested that the Ehairman of the subcommittee and Director of ACHAR farilitate this meeting.

V. Report of MADERA on symptoms of a di sease in Kunar:

The agency sent a veterinarian to the area to purchase a sict: animal and bring it to Vfer-Feshawar for examination. The result of the serum sample was negative.

VI. Discussion on UNDP drafted policy on privatization:

Different agencies expressed their views in this regard. DCA said that it is mot a proper time to implement this poliry. Cutting $10 \%$ from the paravets will demotivate them which on the other hand will damage the quality af work. DinA said that two weeks bark the issue was discussed with two UNDF offieials in Islamabad and they did not have any idea about the future.

IRC said that since there is a trangfer of services from UNDF to FAO in the near future, why not wait until the transfer takes place and then discuss it with FAO. IFC: requested clear clarification from UNDF in this regard.

ARC had the opinion that the loral community does not have the protential to buy medicine at full bost. AFi: said that the present $80 \%$ and even $40 \%$ charge is out of the ecomomic capability of the community. AFiz: adoded that they are not supporting free services but their should be ways to develop independence. APC: said that shifting this business to privatization at this time will make the veterinarians shopleepers. 
GAF said that with maving the charge to $100 \%$ quality of work will glo down.

Finally, it was suggested that Frogram Manager-UNDP along with other senior UNDF veterinary officers should be invited ta a sperial meeting to discuss mainly the following points:

- Is the polisy effected from July first?

- Is it the right time to apply? Why?

- Why does the private business mat:e the program sustainable? - What about supply at village level?

The date for the meeting was fixed Sunday Margh 7.92.

The attendants:

Dr. Housaini (chairman)

Dr. Nehr aban/Dr. Nasseri/Dr. Sedi qull ah/Dr. Ebrahimi

Dr. Wassint:Dr. Halioni/Dr. Oasem Alemzada

Eng. Matud Fabir

Dr. Sayed Mothd

Noir Agha

Dr. Neil Ehestertan

Allen Jelich/Dr. Naysam

Dr. S. Ahmadzai/Dr. Bul Afaal/Sáfi/Dr. Shafiq

thalil ur Fiahman

GAF

UNDF

DC:A

PFB

$C / 0$ GAE:

AFI:

COMDEV

IFL/RPA

CREA

ALBAR 


\section{7}

\section{VETERINARY SUB-COMMI TTEE}

\section{Minutes of the special meeting called to cliscuss "Drug Supplies Future Poliry" prepared by UNDP \\ Sundlay 7 March, 1993}

The members of the sub - committee disclussed on issues of concernon a draft prepared by the UNDP/OPS Peshawar as the future policy regarding the possihility of medicine supply through the private businessman to be sold at no subsidy to the farmerslanimal owners.

The, senior veterinary officer of the updp said that the UNDO/OPS Frogramme Manager was supposed to attend the meeting, but due to his prior scheduled meeting in Islarnabad he was unable to attend this meeting.

The drafted policy proposes the encouragement of medicine supply system with the help of private traders at province, district and even village levels, with no subsidy at ali effective July 1973 . In respone to a guestion is lio "whether the policy would be accontable th the farmers. at this stage of time that there is desperale need for help to the vast majority of the people." The linpp representative responded that the same was the conrern at the proposal ol each policy change from free distribution to so and oo percent charging policy respectively. Privatization of the? medicine supply reerla no control from the ronor ar the Noos. side with respect to the resale of the medicine to the black market or other loses.

MADERA is going to implement this policy to charge $100 \%$ the price of medicines to the farmers after Jume 1993 . It was reported by MADERA that local siopkeeners do not want to invest in this business as long as line NGOs provide the medicines with subsidy. to the clinjes in the areas they
work.

The members of the sub - commitieg also pointed lo the possibility that $F A O$ might take over the programme from the beginning of the next year or even sooner currently funded and supervised by unDP/OPS Peshawar and there will 1 mylnow be change to a totally different policy so why advocate a change with this short forcible time that will happen otherwise. It was suggested that it would be good if UNDP/OPS and FAO comes to a decision that with whom thr NGQS will be signing the ronterets after Jume this year and for how long?

The chäirman, in principal, was not against the policy, hut the time for the policy was not suitable he said. Also the proposed policy will have the following sethacks under the 
- given circumstances: it will not help the repatriation of the refugees, there are serious reservations about the supply of medicines to the remote districts and the districts whert inhabiled by subsistence framers rather than nomads and more important is the fear of de-motivation of the paravets and vaccinators. DCA and IRC seconded the inotion and added that the policy needs more discussions with respert lo the justification and evidences on the statement in the drafted policy that undP/OPS thinks this is the appropriate "time to implemerit.

In principal, all the participants agreed on the policy, but several aglencies emphasized lhit this is not the proper time to implementation this policy.

UNDP/OPS representative the meeting said the drafted policy is open for discussion, $F A O$ may also be involved in the coming lalks.

\section{The participanl:}

Housaini

Sanaul Haq Aliamadzai

Sediqul 1 ah

Mehraban

Anthony Badha

A.A. Nasseri

M. Kazem

Ghulam Saeed

Alain de Bures

Gerrit Wassink

Allen Jelich

Maysam

Shatiq Ahmad

GAF
CRAA
UNDP / OPS
UNDP/OPS
FAO MaZAT
UNDP/OPS
PRE
MADEFA
MADERA
DCA
IRC/RPA
IRC/RPA
ACHAL

GAF

CRAA

UNDP / OPS

UNDP / OPS

FAO Mazar

UNDP /OPS

PRE

MADERA

DCA

IRLIRPA

ACHAK 


\section{$A C B A R$ \\ VETERINARY SUB-COMMITTEE \\ Minutes of the meeting held on Tuesday. March 16,93}

\section{Announcements:}

A. GAF said that they tool: charge of the two veterinary rinies of AFC In Shamazar and fharwar districts of logar Frovinee. A monitor of the game program was also hired by CjAF. GAF will consider the employment of other staff of these rinies in the future.

GAF added that taking charge of two other alinics of AFi: is also under negotiation. These clinics are located in Jaghor $i$ and Malistan distriets of Ghaznj. provinre. According to GAF, the $c$ inic of AFI: in Khoshi of Logar Frovince is handed ever to DCA.

B. GAF approved a elinie for Mosahi sub-district gf rabul Frovince. Another clinio was approved for Waza Zadran of Faktia Frovince. Some medicine was also sent to this 'tellinic.

C. A team of trainers (two) from Mi:I-0uetta came to Feshawar to provide a-week training to the trainers of GAF. They will teach Teaching Methodology. UNDF found the training very effective and useful.

II. Report of DCA -PRB and GAF about problem in Parwan:

A monitoring team composed of the representatives from GAF, DEA and FFB made a trip to farwan Frovince. The purpose af the trip was to make an assessment of averlap cocurred in Jabal-u-Sara.j District of that province by these NGOS. The team returned and reported that the olinies of GAF and DEA are lowated lose to each other in the district. The recommendation of the team was that since DCA clinic established earlier than GAf, it can stay in the district and GAF will move to angther area. Foth agencies agreed an the decision.

\section{I. Report of MADERA about lab results:}

The representative of the agency was not present in the meeting.

IV. Any other business:

A. The eriteria of having Gombined monjtoring team to an area was emphasized. It was said that this will provide more guarantee about the reliability of monitoring. DCA $5 a i d$ Ea start this type of monitoring, the agencies monitored should be on the same policy line.

UNDF requested the agencies to riroulate a ropy af their annual monitoring schedule if any. This can bring the agencies to a mont toring coordination.

B. CFAA field staff observed signs of a disease in sheep and goats in kunar. The disease li illed $50 \%$ of animals in two flacks. Lung, heart and spleen of an infected animal were brought to VRI-Feshawar. The result of VPI showed E. Coli. some members of the Sub-ormmittee sajd that E. coli is not 
that fatal in old animals. It might be contamination of any ather disease. It was suggested that a wholé" animal could be brought to Feshawar to be examined for the aintual casual agent af the disease.

GAF thanked EFAA providing temporary starage facility for their commodities in Jalalabad. GAF said that they have similar facility in liost and can be used by agencies.

\section{The attendants:}

Dr. Housaini (ehairman)/Dr. Zat:er/Dr. Ghaf our

Dr. Wassink/Dr. Hal i ini /Enayatull ah

Dr. Metiraban/Dr. Nasseri

Dr:Basir

Dr. Kazen

GAF

DC:A

UNDF

FRS

PRE

thalil ur fahman

ACBAR

The agenda for the next meeting whilh will be held on Tuesday April

6. 93 will be as follows:

1. Minutes of the previous metetings.

II. Anngunisements.

III. Discussion on UNDF drafted Folicy. IV. Frogdures for field veterinarians how to ballect samples and how
to report it.

V. Fesults of negotiations with UNDP Gificials.

VI. Any other business. 


\section{$A C B A R$}

\section{VETER INARY SUB-COMMITTEE}

Minutes of the meeting held on Tuesday, $E$ Apri] $g 9$

\section{Minutes of the previous meeting:}

A. Fage 1, item I-A should read "GAF" said that they will tale charcle of the two veterinary olinis of Aro in Ghanazar and bharwar distriets of Logar provino.".

E. Fage* 1, item II, the last line of the paragraph should read "EAF, DI:A and FEE al a agreed on the deojsion.

Discussion on UNDP policy on medicine supply to the VFUs frcim July 1993 onward:

DE:A made the following oomments on the policy:

Eage 1. the last paraciraph:

..thejr main Gornern is the possibility inadequate or no sully of medicine....

The medieine supply system for the BVWs is the problem, and this is not the anly arne. Other problems are inistales in some ases in the selection of the EVWs and low level of jnoentives might: result in lact: af motivation from the side of some bVWs.

Aecording to the UNDF report 50 far 400 BVWs are trained by different Nisos, based an monitoring reports that only $50 \%$ of the? trained EVWs were active after a period of $6-12$ monting of the evalluation report.

\section{Eacie 2:}

Wher advantages of the full prjec charging system are being compared versus disadvantages of the subsidized setup it would be appropriate to also ampare the vige versa.

Disedvantages of the tharging policy:

- Small holders and recently repatriated refugese a an hardly afford the $80 \%$ cost reavery on medicine. The $100 \%$ aost reagvery wjll be extremely di.fficult j. not impossible under the present situation in Afghanistan.

- The drastic changes in the charging system and the price hite without proper evaluation on bi as bases of the rurrent $80 \%$ Eharging policy will have negative jmpat on the veterinary services.

- No support and rehabilitation assistanes will be provided to the newly repatriated refugees who are generally in need af rel.ief assistarion.

Advantades af the subsidized systen:

There "is a more effective use of the $Z$ pjll ars of the veterinary service system cvareinations and deworminges. 
Speraldy the suald holders and the reantly repatriated refloges are supported.

Fage $3:$

... therefore, we expet a gap ........

To the opinion of DoA, the expertation of a gap is exaggerated. Seen the last par agraph af page 3 were UNDF expecte to iset up a private sector in 6 moths to one year, it will be easy to

- prevent; a gap when UNDF mates their poliaies alear in an early ata

It was said that there are gone medicines for whiah there is no or low deranded (i.e. Valbageri) by and nal owners as the gost is high. In Northern Afghanistan, the same medicine is provided cheaper by FaO reparted by Pres.

\section{I. Arux otiper tolsiness:}

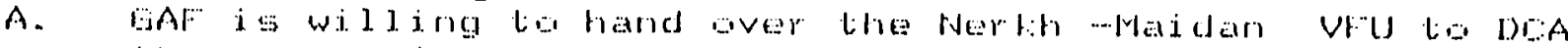
the only alinio in the province beoase of the supply and monitoring difficulties and will tate a Elinis from DoA in another area. DoA has mare clinics in the neighboring distriats. GaF suggested the same approan by the sister NGOs for the efficiency of the field operations. agencies to bring their activities under this formula.

13. Whof intends to train women BWWs and in the Livestors Management sector joside Afghanistan. The interested

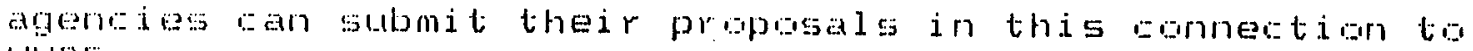
LINDF.

The atetendants:

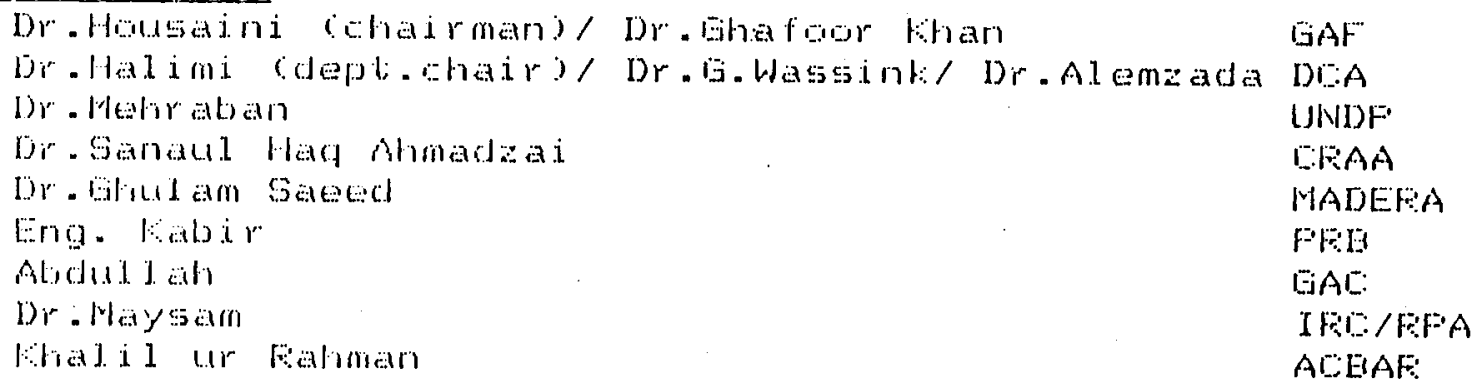

The agenda for the next Vet. Sub-ormittea meeting whibh will be hesd an Tuesday, 20 April 63 is as follow:

1. Approval of the agendat.

J. Hinutes of the previous meeting.

II. Fathological Gample Gol leston Guidel ines prepared by Dr. Nasseri. IV. Frodures for mediaine supply to the alinias.

V. Any otiligr business.

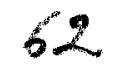




\section{Minutes of the meeting held gr ruesday, 20 April 93}

\section{$I=\frac{\text { Minutes of the previous meeting: }}{\text { Approved. }}$}

\section{I. Announcements:}

OOMDEV office was bjosed end of Mareh 93.

Dr. Neil Chesterton, Director of combev and the previous chairman af Veterinary Sub-oommittee, attended the sub-o. He was thanked for tor the last time before leaving Fata Eommittese efficient lye efforts paid ruming the sub-

his turn appreajated the cog his chairmanship. Dr. Neil in rendered to him during his toperation af the menber actere ies wi.1]. be happy if Gan find themes. Dr. Neil added that he owners af the Afghan Gommunite opportunity to serve animal.

I I . Patholoqical Sample collection Guidelines -by Dr.Nasseri -

A handout in 8 pages prepared by UNDF/OFG was distributed jn the meetirg. The hand out contained information on how to tat:e blowd and send pathogenio samples to a diagnostio lab. A committee composed of Dr. Halimi, Dr. Oasem and. Dr . lanem was assigned to finalize the handout and bring it ta the next Sub-rommittee meeting. Other members were al so ast:ed to read the handout and convey thejr views to the womittee to be Gonsidered before it is finalized. The handout was in
Darj. Language.

Procedures for medicine supply to the clinics:

Although $100 \%$ oharge on medicine was agreed on in the last ineeting of agenejes with Bob Eaton. But some agencies mainly Di:A bel ieves that $100 \%$ robarge may not wort: due to some reasons stated in the previous meeting. Dias said that äcording to their survey results from la districts, most af the shuras disagreed with the increase.

Finally, it was said that it was agreed on pereentage but the ways of implementation should be further discussed.

Any other business:

A. FFE guestianed j. any of the veterinarians referred to the Technioal Committee fails to pass the first exam, would he be given the ohance for the seand and third time. The Technial committese meanbers said that he is re-exanined after 3 months.

B. LNDF/OFS said that their monitors bane from kunar Frovinee said that some BVWs have opened their own shop selling animal medicines. Acoording ta the monitors, 
the BVWs matie Afs. 3,000 to $30,000 / d a y$. The monjtars al 50 reported about a small problem aused by the difference in charging perantage. Two olinics; one from MADEFA and the other one from EFAA have been 1. Gated a osely separated by a river. GFAA aharges BO\% where MADEFA warger lower than that whish is anfusing the vil. 1 agers.

L.NDDF monjtors also visited MADEFA's poultry farm and the bab which were impressive.

\section{The attendants:}

- Dr. Hwissani cohadrman?

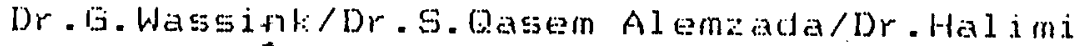

EAF

Dr. Metir atandor. Nasser i. Dr. Eborahimi

Eng. Fabir/Dr. Fazem

$D i: A$

UNIDF

Dr. Neil Ehestierton

PFE

Dr. S. Ahmada a 1 Dr. Nawabi/Dr. Sha fi cl

GOMMIDEV

Dr. Bihul arn Saeed

DF:AA

M. Däıd Jiddi

MADE:FA

A. Shat:oor

AFIDA

foal i l ur fahman

GAC:

ACEAR

The agenda for the next meteting whioh will be treld at $8=30$. Tuesday, 4 May 93 will be as follows:

1. Approval of the agenda.

II. Minutes of the previous meating.

II. . Announcements.

IV. Final form of the handout prepared by UNDF/OFs.

V. Noge field activity proposed logations from June onward.

VI. Any ather business. 
$\Xi$

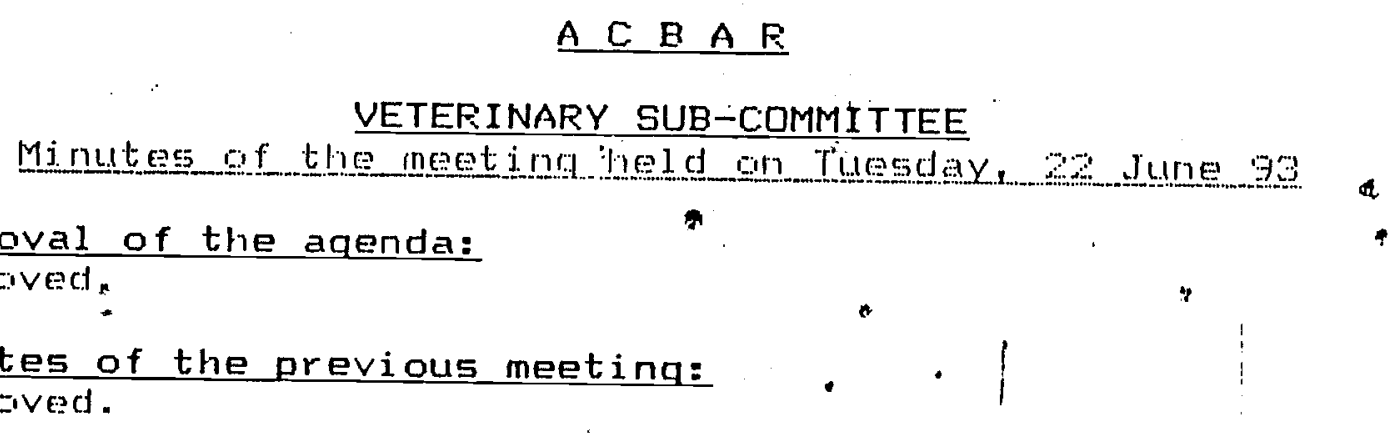

Appraved.

\section{I . Anrouncements:}

A) MADEFA saj d that agenajes ingluding UN) who are going to

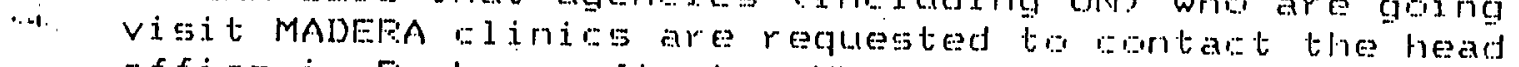
office in Feshawar first. LNDF said that although the last visit from MADEFA rlinias was on the personal bases but they have the right to inspert MADEFA clinics until they are formally informed about the alosemo of the projest. UNDF said that they have some equipment in MADEFA clinics ta be returned ta the UN agency.

E) UNDF anmouneed that funding to all UNDF --funded veterinary projegtes was approved for a year more cerrd June 94). DaA suggested that there are some nistaties with the proposals and should be reviewed by the Nojos befrore they are sent to
New Yort:

a) Afghan Development Assogiation CADAs needs a veterimarian

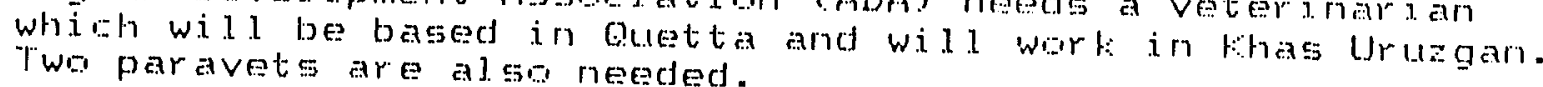

D) UNDF said that there are some Quetta based NGOs with

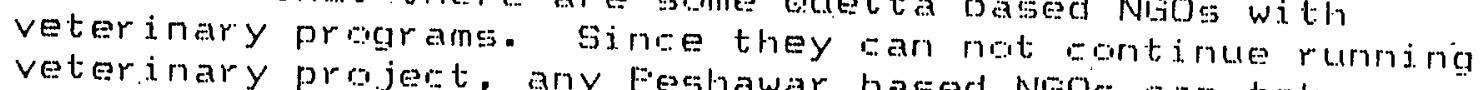
veter.inary project, any Feshawar based NoOs a an tabe over

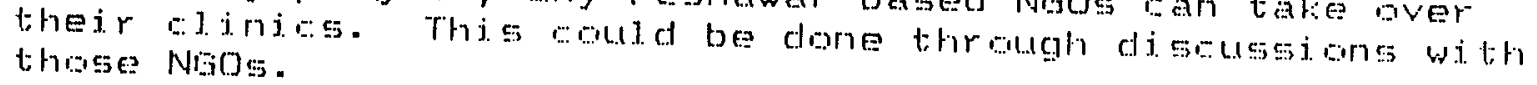

IV. No. of BUWs/district:

At the beginning it was approved. that an average of lo fows should be trained per distriot:. After more than a year from the start of the program, it was found that in some distriats the

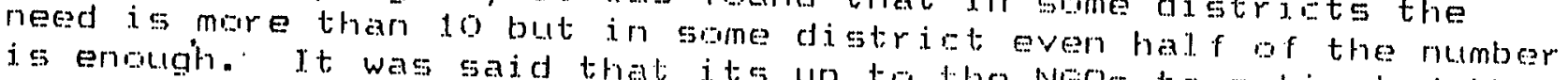
needed number of BVWs per distriat. to the NGOs ta estionated the

For ill joterate trainees EAF has provided traming with the manual prepared by MoI. There were aontroversial ideas whether to selest literate or 2.2 grade graduates to be trained as BVWs. this job and try for ather opportunites of, lith grade may laves even if scome do not warit topportunities. But it was said that will be used by the community. EVWs, they have thes landedge and not be able to get the proper fhe i.l. iterate candidates inght 
V. Any other business:

GAF said that there are eproblems in hand over of alinies from one agency to another. Staffing is one of the main issues. DCA clinice in Faghman which is going to be handed over to GAF has this problem. Under the present policy some staff of this clinie should be redundant or shifted ta other clinics. UNDF said that they isuld be staffed in sub-BVFUs.

The attendants:

Dr.Hussaini Chairmang/ Dr. Ghafour than

Dr.Eerrit -Wassezint:/ Dr.M. Hal imi

Dr. Mehraban/ Dr. Nasseri

Dr. Maysam

Dr. S. Ahmadzad. / Dr.M. Shafic

Dr. Sayed Mohammad

Mary Edwards

Deborah Stories

M. Haroon

Dr. Bthul am Gaeed

Fhad i 1 -ur-Fahman

GAF

$D C A$

LNDF:

IFI:

DFAA

Indepp Eonss.

IAM

FFE

* MADEEA

ALEAE: The agenda for the next meeting whilo will be held an Tuesday, 6
August 93 will be:

I. Approval af the agenda.

II. Minutes of the previous meeting.

III. Announcements.

IV. NGO sites of Eliniss -UNDF.

V. Formate of the field report formes -UNDF.

VI. Any other business. 


\section{$n$ C $B$ i $R$ \\ VET SUR-COMMIT'LEE \\ Meeting held at 2-5 pm Thursday July 8,2993}

'lhe meeting was called to discuss the:

format of field report

defining the target areas and transferring vet centers between NGos.

PIEIII) REPOR'I:

Copies of the form "Veterinary field_unit Monthly_Report", prepared br UNDP, was distributed in the last seminar for comments. UNDP monitor: have also collected some more forms/registrations/record sheets the best ones of which were distributer to be reviewed. If accepted by HGOs, UNPD will print them under the name of each NGo and distribute

thein.

UHPD explained the purpose of the form as a tool for collecting some information on outbreak j.ncidents in different areas on the basis of which a map/summary of diseases could be drawn and necessary vaccines and medicines be provided accordingly. Nlso the efficiency of vaccines and vaccinators will be found out. In the reverse side of the sheet it is explained in simple words how to fill it.

DCA was of the opinion that the information collected by the vet staf: in the field will not be appropriate for starting an epidemiology alndy in view of the current situation in $\lambda$ fghanistan. DCA suggested that symptoms should be recorded instead of diseases which could late on ho analyzed by an expert. DCA also suggested that a questionnaire could be designed asking local names of diseases from the farmers select some villages on the basis of the replied questionnaires and sond some enumerators to interview the farmers and find out the exact inciclents.

Arter olle and half hour discussions without agreement UNDP stated that it: was what they wanted as the donor for the project and expect NGos to fill it per unit per month. It will not be a perfect study but it would be something and better than nothing. UHDP's revised gllestiomaire for monitors have now got questions about the local names of diseases which could be used as a second source of information during analyzing line lita.

UnDP will print the form and distribute it to NGOs. be fillod in the field and not in the main offices. kept by NGOs but the original must be sent to UNDP.

'The form should $\Lambda$ copy could be

'Ihe clescription sheets ând vaccination cards will also be printed by. UNDE in small book-let in order to be carried in the pockets of vet staff.

$\lambda$ now form "Field Visit Record", prepared by Undp, was distributed for comments. The purpose of this form was to know whether the vvis who have been provided motorcycles and are paid Rs.100 per day visit VFUs and villages or not. UNDP does not want the form back but thinks it would be userul ror UNDP as woll. ass lNoG monjtor. Most of NGOs thoughr the form for create problems for them.

$\Lambda$ few NGOs e.g. G $\triangle F$ will use 


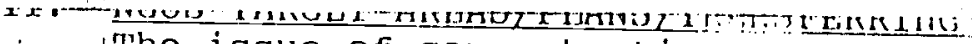

The issue of concentrating lhe target wids to facilitate supplyin. and monitoring were discussed in the past meetings. NGOs who have $I_{2}$ single Vrus in different areas will leave them to those who have more vet centers there. On the bașis of these the NGos indicated their ongoing and plans VFUs as follows:

\begin{tabular}{|c|c|c|c|c|}
\hline NGO & PROVINCE & $\begin{array}{l}\text { DISTRICT. } \\
\text { (ongoing) }\end{array}$ & $\begin{array}{c}\text { DISTRICT } \\
\text { (proposed) }\end{array}$ & REMARKS \\
\hline $\begin{array}{r}\text { PRE } \\
\vdots \\
\vdots \\
\end{array}$ & $\begin{array}{l}\text { BAGIILAN } \\
\text { KUNDUZ }\end{array}$ & $\begin{array}{l}\text { Khoi Safi } \\
\text { Charikar } \\
\text { Bagram } \\
\text { Baghlan } \\
\text { Dahna Ghori } \\
\text { Kunduz } \\
\text { Dasht Archi } \\
\text { Aliabad } \\
\text { Char Dara } \\
\text { Taluqan : } \\
\text { Rustaq } \\
\text { Bangi } \\
\text { Chahyab } \\
\text { Yangi Qala } \\
\text { Khwaja Ghar }\end{array}$ & $\begin{array}{l}\text { Katawaz } \\
\text { Sarhawza } \\
\text { Zelook } \\
\text { Sarobi } \\
\vdots \\
\text { Sultan Khel } \\
\vdots \\
\\
\text { Sayed Karam } \\
\text { Jani Khel } \\
\text { Musa Khel } \\
\text { Salang }\end{array}$ & $\begin{array}{l}\text { DCA Zama VFU can be transferred } \\
\text { to PRB. } \\
\text { Currently with GAF. } \\
\text { Mandozai seems to be covered by } \\
\text { IRC VFU now taken over by GAF: } \\
\text { A joint PRB/GAF/UNDP team wil: } \\
\text { to see the needs. }\end{array}$ \\
\hline $\mathrm{DCA}$ & $\begin{array}{c}\text { GHAZNI } \\
\vdots \\
\cdots \\
\cdots\end{array}$ & $\begin{array}{l}\text { Nahrin } \\
\text { Anderab } \\
\text { Khost/Fring } \\
\text { Yakawlang } \\
\\
\text { Deh Yak } \\
\text { Jaghatu } \\
\text { Qarabagh. } \\
\text { Muqur } \\
\text { Andar } \\
\text { Nawa. }\end{array}$ & $\begin{array}{c}\text { Bamyan } \\
\text { Shibar } \\
:\end{array}$ & $\left\{\begin{array}{l}\text { Yill take over from GAF. } \\
(\mathrm{DCA} \text { will leave Gj.ro to GAF.) } \\
\vdots\end{array}\right.$ \\
\hline
\end{tabular}




\begin{tabular}{|c|c|c|c|c|}
\hline NGO & PROVINCE & $\begin{array}{l}\text { DIATRICT } \\
\text { (ongoing) }\end{array}$ & $\begin{array}{l}\text { DIElRICT } \\
\text { (proposed) }\end{array}$ & RELARKB \\
\hline $\mathrm{DC} \Lambda$ & 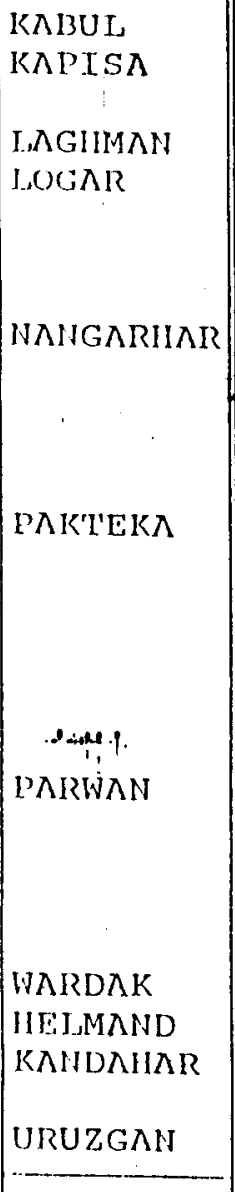 & $\begin{array}{l}\text { Paghman } \\
\text { Panjshair } \\
\text { Nooristan } \\
\text { Khoshi } \\
\text { Azra } \\
\text { Kulangar } \\
\text { Jalalabad } \\
\text { llesarak } \\
\text { Deh Bala } \\
\text { Khogiani } \\
\text { Sherzad } \\
\text { Dila } \\
\text { Nazakhwa } \\
\text { Gomal } \\
\text { Barmal } \\
\text { Shinwari } \\
\text { Jabul Saraj } \\
\text { All districts }\end{array}$ & $\begin{array}{l}\text { Wol Mamay } \\
\text { Jani Khol } \\
\text { Surkh Parsa } \\
\text { Shaikh } \wedge \perp i \\
\text { lladi } \Lambda 1 \mathrm{i} \\
\text { Shawali kot } \\
\text { Maruf } \\
\text { Shahristan }\end{array}$ & 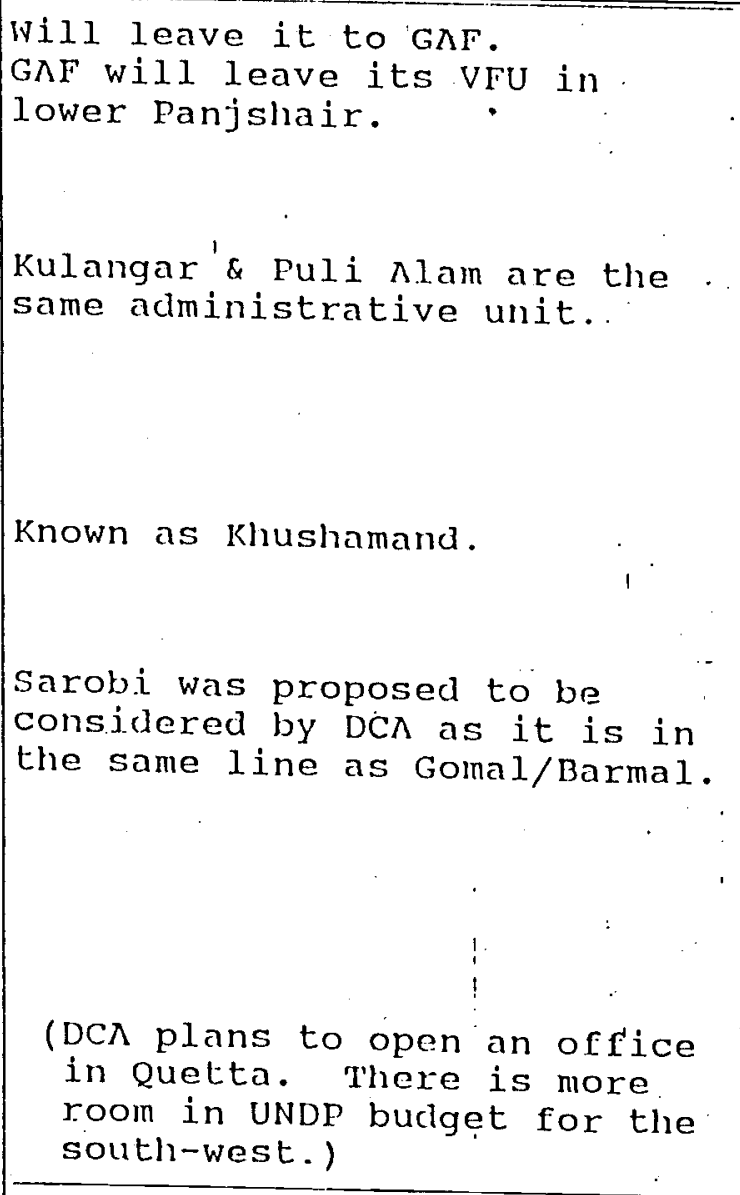 \\
\hline $\operatorname{cI} 2 \Lambda \Lambda$ & $\begin{array}{l}\text { KABUL } \\
\text { KATISA } \\
\text { KUNAR }\end{array}$ & $\begin{array}{l}\text { Sarobi } \\
\text { Bagrami } \\
\text { 'lagab } \\
\text { nsadabad } \\
\text { Chapa Dara } \\
\text { Narang } \\
\text { Khas Kunar } \\
\text { Sirkanai } \\
\text { Nour: Gul } \\
\text { Qarqhaie } \\
\text { Shinwar } \\
\text { Bati Kot } \\
\text { Rodat } \\
\text { Nazian } \\
\text { Mchin } \\
\text { Surkh Rod } \\
\text { Bnhsud }\end{array}$ & $\begin{array}{l}\text { Khak Jabar } \\
\text { Nlalasay }\end{array}$ & $\begin{array}{l}\text { Located in Wata Poor } \\
\text { Located in Dara Mazar } \\
\text { Located in Kas nziz knan } \\
\text {. } \\
\text { n sub-viv as it is not a distr. }\end{array}$ \\
\hline
\end{tabular}




\begin{tabular}{|c|c|c|c|c|}
\hline NGO & PROVINCE & $\begin{array}{l}\text { DIBTRICT } \\
\text { (ongoing) }\end{array}$ & $\begin{array}{l}\text { DISTRICT } \\
\text { (proposed) }\end{array}$ & REMARKS \\
\hline $\mathrm{G} \wedge \mathrm{F}$ & $\begin{array}{c}\vdots \\
\text { NANGARHAR } \\
\vdots \\
\vdots \\
\text { PAKTIA }\end{array}$ & 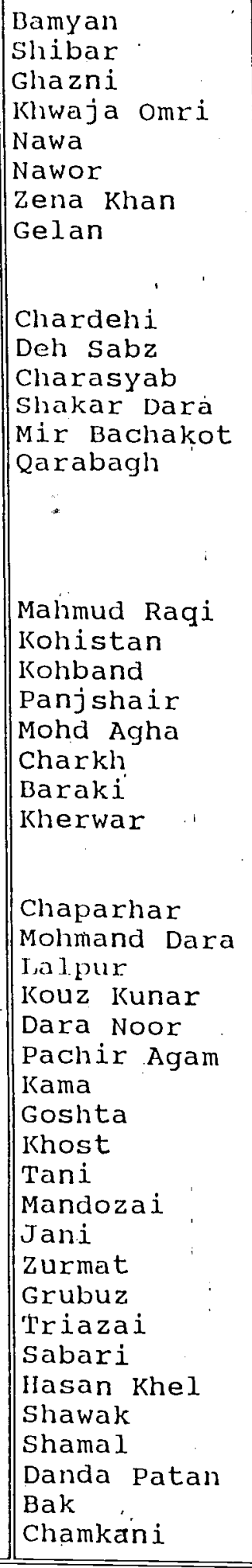 & $\begin{array}{l}\text { Paghman } \\
\text { Istalef } \\
\text { Kalakan }\end{array}$ & 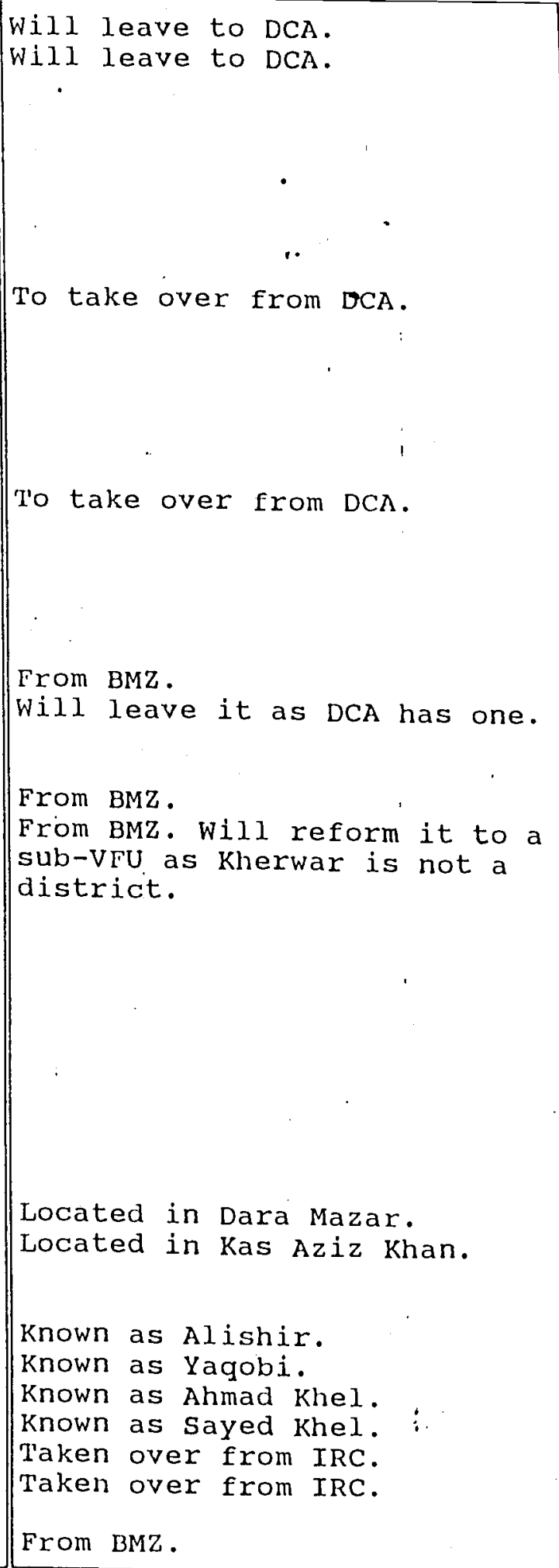 \\
\hline
\end{tabular}




\begin{tabular}{|c|c|c|c|c|}
\hline NGO & PROVINCE & $\begin{array}{l}\text { DISTRIC' } \\
\text { (ongoing) }\end{array}$ & $\begin{array}{l}\text { DIS'RICI } \\
\text { (proposed) }\end{array}$ & REMARKB \\
\hline $\begin{array}{c}\text { GAF } \\
1\end{array}$ & $\begin{array}{l}\text { PAKTEKA } \\
\text { PARWAN }\end{array}$ & $\begin{array}{l}\text { Sharan } \\
\text { Mata Khan } \\
\text { Urgun } \\
\text { Ghorband } \\
\text { Gulbahar }\end{array}$ & . & $\begin{array}{l}\text { Proposed to leave it to DCA/PRB } \\
\text { From BMZ. } \\
\text { Closed as was overlapping with } \\
\text { DCA. }\end{array}$ \\
\hline
\end{tabular}

Mohalmmad Khel in Pakteka (between Sharan and Katawaz) was reported to be i] need of vet services. As it is not a district a sub-VFu can be established.

I.I. A. O. B.:

- UNDP have asked for quotations for vaccines from Holland and Australia. Once the received come the NGOs will be contacted to see their requirements and needs. NGOs should not stop buying vaccines they need currently as it takes up to five months to get vaccines frol Holland/Australia.

- In reply to a question from DCA, UNDP said that FAO-Kabul does not intend to rehabilitate the vaccine production institute in Kabul in the immediate future. As vaccine and vaccination is expensive it is important to have effective vaccines. DCA was of the view that in the long term when the UNDP stop importing vaccines it would be very difficult for the government of Afghanistan to import vaccines paying hard currencies.

- PRB will give a party on sunday July 11, 1993 in the honor of Mr. Gerrit Wassink, the Director of DCA, who is leaving. Two people
from each agency are invited.

\section{ATTENDANCE:}

IIussaini

Ghafoor Khan

M. Ilalimi

Gerrit Wassink.

M. v.d. Dool

Sanahulhaq

Marion

$\begin{array}{lll}\text { GAF } & \text { M. Kazem } & \text { PRB } \\ \text { GAF } & \text { Mohd Kabir } & \text { PRB } \\ \text { DCA } & \text { Ebrahimi } & \text { UNDP } \\ \text { DCA } & \text { Sediquilah } & \text { UNDP } \\ \text { DCA } & \text { Nasseri } & \text { UNDP } \\ \text { CRAA } & \text { Mehraban } & \text { UNDP } \\ \text { Ind.Cons. } & \text { Shakir } & \text { ACBAR }\end{array}$


72 


\section{$A$ C B A R}

\section{VETERINARY SUB-COMMITTEE \\ Minutes of the meeting be]d on Tuesday, 27 July 93}

I. Approval of the agenda:

A) "Construction of Animal clinics" a presentation by $\lambda F A$ was added under any other business.

II. Minutes of the previous meeting:

Approved.

II Qualifications, training and requirements of nonprofesisional monitors:

Previously the procedure was to chose DVMs for this purpose. - But lately non-professional monitors are also hired by some agencies to monitor thoir projocts.

DCA said that they trajned such people for 2 months in management: and administration. people with agriculture background were given the priority. But now its not limited to this background. DCA nlso proposed that a Report: Writing course should be taken by these non-technical monitors.

GAF said that behavior of the person toward the community is more important. They should have the capability of receiving training at least at bVW level. They should have basic veterinary knowledge and know about animal medicines. If they do not have this knowledge, they should undergo a BVW course. SCF-UK managenent colurse is very effective. GNF already had 3 non-professional monitors and they perform their duties in a satisfying manner.

UNDE sajd that monitoring forms should be present. Each vFu should have separate report and then an integrated report o: all VFUs belong to a clinic should be prepared.

GAF proposed to having a standardized formate for monitors what to be monitored. UNDP said that they have some monitoring forms and could lue userl to produce a standardized one. Then, it was proposed to set-up a group composed of members from involved agencies to discuss the issue and report it to the next Veterinary sub-rommittee meeting. Following are the names of group members:
- Dr.S. Dqa
- Dr. Halimi
- Dr.Kazem
- Dr.shafiq or Dr.zahir
- Dr.seddiqullah
GAF
DCA
PRB
CRAA
UNDP /ORS The group will meet on Monday, 2nd August at 9 am in Dutch
Committee. 
74 
IV. New arrangements on supply of medicines to the field Units:

Policy of the NGO for supply of medicine was that a doct.or and a para-vet from the clinic came to peshawar guartierly ard received the mediciries. But with the riew ar guartierly zonal offices have been arranged in khost, Jalalabad ang Ghazni. The field units will get their medicines from the nearest zonal office. According to GAF this systell is sat ancl saves lime arici inoriey.

\section{CRAA}

The agency said that according to the previous policy, the sale of medicines gain only half of their salary from thr was paid by the agency. other services. The remaining half new policy, the agency called ine, with the introduction, to peshawar and aiscussed the all its technical field staf 1 werte given ore: arid hal $\dot{\mathrm{E}}$ nonth new policy with them. They the bases of a pilut project. payment and the medicine on result within a month or two. The agency will evaluate the prograrn.

The aysency is planning lo have a store in kabul and one in Jalalabad. l'neir field units can get medicines from thess stores. GAF said that they are going to talk to CRAA and will try to supply their clinics around kabul Erom CRAA Antibiotics) (an supply medicines (only Anthelmentics and agencies about their quartencies if asked. CRAA will ask so that it will know what type half a year or full year need needed to be supplied in their of medicine and how much is case, CRAA will charge in this Lransportation, storacje ari some amount to cover the

DCA

The agerc:y is st.ill thinking of having a store in Jalalabad. DCA is planning to pay the salary in kind. DCA mentioned that there are some problems with this system.

\section{PRB}

The previous policy of the agency was to send to the clinics and there in the clinics the were filled out arid salries were left at the clinic after salary paid. The surplus moncy the main office arid in calary payment was counted, back to money was sent to the case of short come the additional agency has rnot decided clinic from the main office. The is thinking of having a sthe future policy. The agency Charikar.

UNDP said that Dr.Phillip sent. them a list Erom Mazar-iSharif indicating some of the medicine imported from other counliries. The list shows that there are some medicines with reasonable prices which could be ordered Eor Euluro 
supply. UNDP acled that: they may also contact some companies regarding the availability of some medicines and their prices. There will be no tax on medicines imported by the UN. UNDP is in the process of getting quotations for vaccines. One has been received from llolland which shows high prices.

V. Any other business: $\quad$ The issue of construction of veterinary clinics was The issue of construction of velerinary the construction cost proposed by GTz was very high, therefore, undp did not agree to pay that amount. Under the present conditions undp has an allocation of Rs.25,000 for consitruction of a veterinary clinic. Afghan Engineering Agency ( $\lambda E \Lambda$ ) showed wj.j.ingness to hold the construction of lhese clinics in consideration of having some assistance from some other donors. AEA has talked to HABI'TAT to assist roofing inaterials for these projects. WFP is expected to pay for labor under. "Food for Work Program".

Map of a model cinice comsisted of 2 rocoms was brought: toc tho meeling. In case of fjubl agreoment, the first phase of work will start: in Nangarhar province. UNDe asked the rgencies involved in veterinary activities in Nangarhar to qive list of their clinics to be constructed.

It was emphasized to construct the building in a non-private land.

The attendants:

Dr. Hussaini (chairman/Dr. Ghafoor Khan

$\mathrm{G} \Lambda \mathrm{F}$

M.v.d.Dool/Dr. Hal imi./Dr. Alemzada

$D C \lambda$

Dr.S. Nhmaclazi./Dr. Abdul zaher.

$\operatorname{CR} \Lambda \Lambda$

Dr. Mehraban/Mustami $x$

Eng. Liatify

UNDP / OPS

Kha]. i I-11Y--Rahman

$\Lambda E \cdot \Lambda$

$\Lambda C B \Lambda R$

The next Veterinary sub-commitetee meeting will be held on Tuestay, sugust 10 . The agenda will be:

I. Approval of the agenda.

II. Minutes of the previous meeting.

IIT. Announcements.

IV. Discussion on Monitoring Forms.

V. Any other business -

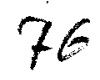




\section{$A \subset B A R$ \\ VETERINARY SLB-COMMITTEE \\ Minutes of the meeting hed d w Tuesday 10 august 9}

\section{Approval of the agenda:}

bonstruation of elinias and VFu stationery were added as items too the agenda under "Any other Businoss".

I I Minutes of the previous meet ing:

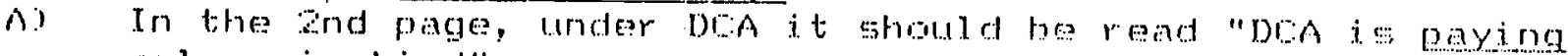
sal ary in find".

I I . Announrements:

A) MADEFA started a course in Fregnanoy Diagnoging Test in Jal allobd. The ageney was informed about the out breal of Anthrax in Shega, Shewa and Hehsood distiriats of Nangarhar Frovince. 10-12 eatile died. The diseaso biss reported based on ciniond symptoms not lab examinations. If was said that the ofisease has also been seen in some other places. It was not seen in sheep and goats. Some members said it might been FMD if seent only in atile.

FrAA has a elinic in Jalatabad and i.t was advised to tatio samplese and sent them for diagnose under thesir procedure. EAA said that the diseace is mostly reported by the Government, Elinic in Jal al abad where physically nothing have been shown. UNDF monitiors, who resentily returned from Nangarhar provines, also have not confirmed the out woreat af Anthrax in that province. They satel that rabag (F) was aommon in Nangarhar provilue.

H) DEA was supposal to tatee over the FAF alinie in Bamyan but: wald not reach to an understanding.

a ADA sajd that they hired a veterinarian in Quetia.

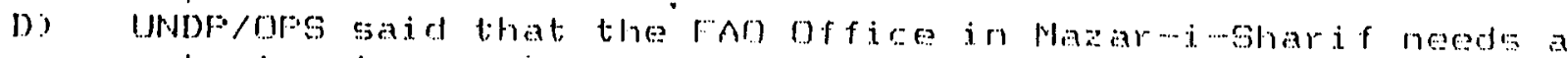

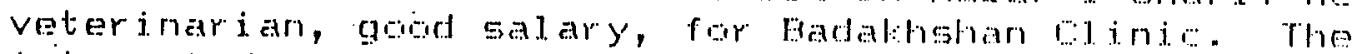
interested candidatos a an cont act Dr. Mohraban at UNDF -.. Festhawar.

IV. Disfussion on Monitoring Forms:

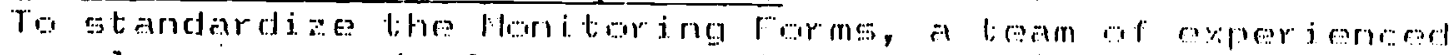
people, composed of representatives from the member acjencies, was asejgoned bo produce a monitoring form. The leam had a meeting and prepared the form. The final formate was presonted to the

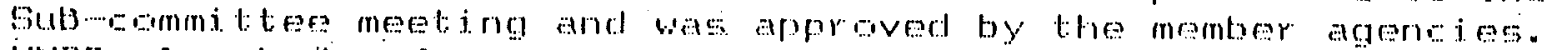
UNDF al so had a form which was shared in the complet an af the final ane. A ropy of the final. form will be sent to all inember

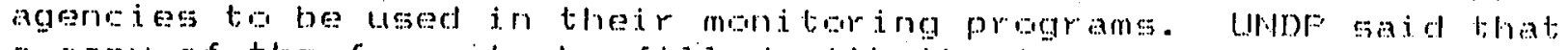
a aby of the form, to be fill led with the information, should be present; in NGO'g file for the confictence of donor. 
V. Any Clliter Huiness:

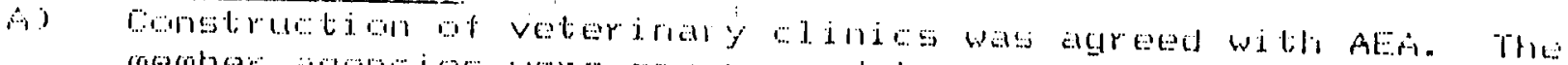

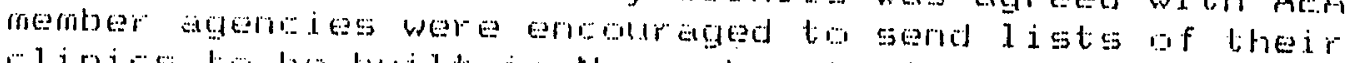

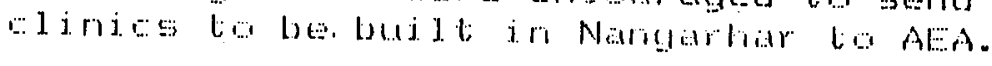

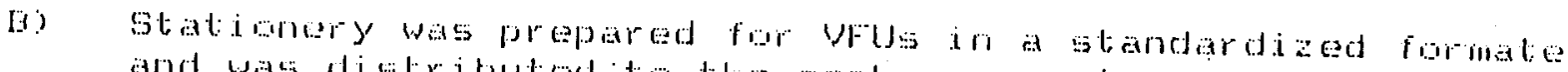

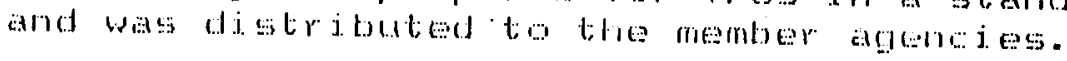

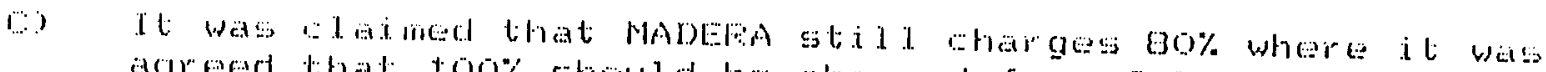
agreed that; Joo\% strould be charged from July ga orward.

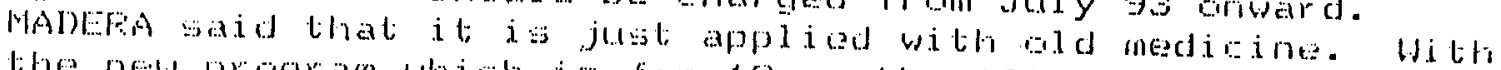

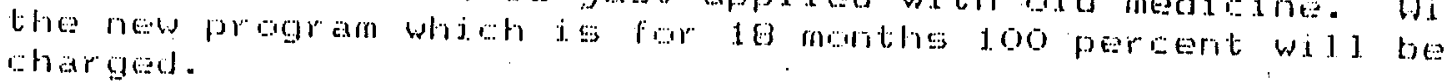

D) MADEFA sajd that the Governont veterinary tolinir in

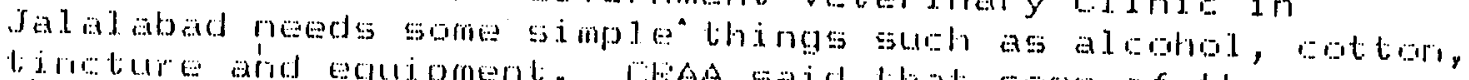

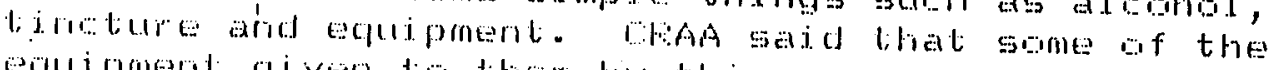

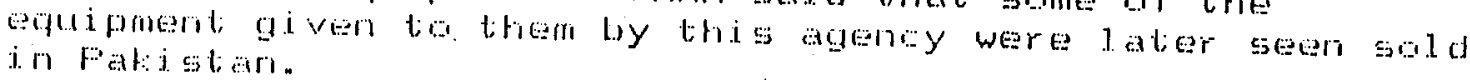

E:) It was shggested that triers is a large number of

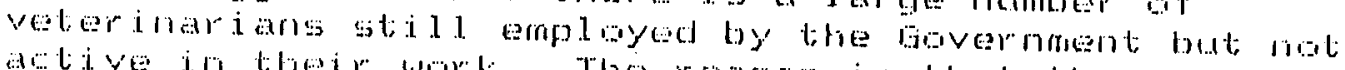
active in thejr worla The reason is that they have no equipment and medicines. In addition lo that lihey are pad a low sal ary whiah an hardly live with. UNDF sad al that

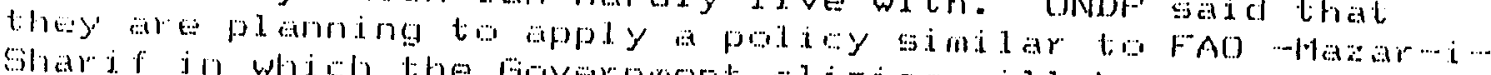

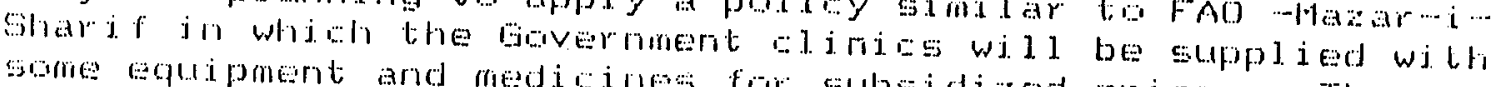

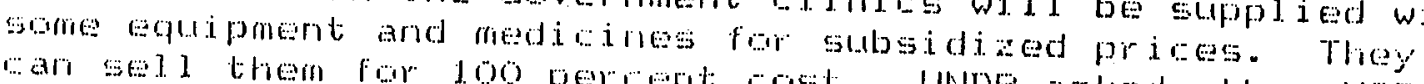

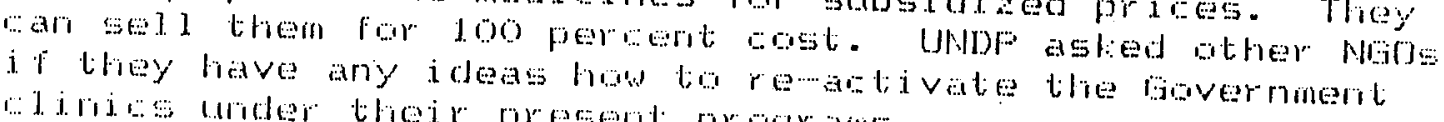

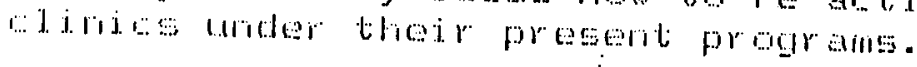

\section{The attendants:}

Dr. Sanalul Hag slimadazi

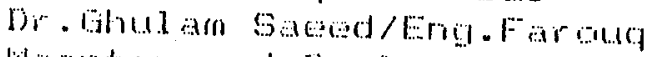

Matar len v.d. Dowl.

Mary Edward:a

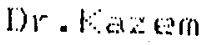

Dr. Melor aban/Dr. Geod quil a ah

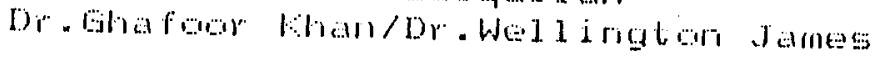

CFAA

MADEEA

DEA

Indep. Gonsul.

FFE

UNDF/OFG

GAF

\section{8}




\section{9}

\section{A $C A \quad B \quad A \quad R$}

\section{Minutes of the meeting held on TuITTEE}

I. Approval of the agenda:

II. Minutes of the previous meeting:

II. . Announcements:

A) Afghanaid attencled tho Voterinary sub-committee meeting for the first time and its representative was welcomed to the sub-committee mettings.

B) The monitoring form has been translated by DCA, and English and Dari. Copies will be sent to the member
agencies.

It was said that a copy set of: the monitioring form should be sent to SWABAC too.

C) MADERA is looking for a well qualified veterinarian to be employed as. in charge of their. Vegal Clinic.

IV. Suggestions of Nangarhar Agric. Department:

Haji Ibrahim. Khan, represnntative of: Nangarhar Agriculture Department, attended the meeting in order to seek assistance of NGOs to their department. He was welcomed to the meeting by the chairman. He stated that the ngriculture Department has the buildings, personnel and sorne basic equipment. There is need for some technical assistance including

Regarding the veterinary section it: was said that there are 1. veterinary staff at the central clinic (yalalabad) siting idel because of lack of equipment and medicine. The representative said that there is a veterinary post in the structure of the most of the districts in Nangarhar. The the government a omointed members were requested to assist clinics.

The Sub-committee members said that there are enough NGO run clinics in different districts and NGOs may not be able to that if extra staff in this regard. The Sub-committee said be officiajly reported to the concerned committee. UNDP said that concerned NGO or the SubJalalabad clinic under the $t$ is possible to assist the Some equipment will be provilicy NGOs' clinjes are funded. could be supplied for provided free of charge but medicine could be supplied for 100 b charge if such an assurance is 
given. Haji Ibrahim Khan principally agreed but said that it should be: discussed with the authorities

Regarding the training to the veterianry staff of central clinic of Jalalabad, it was said that a number of staff
cuuld be considered.

The attendants:

Dr. Hussaini/Dr. Ghafoor

- Dr. Mehraban/Dr. Nasseri

Dr. Halimi

Dr. M. Tahir/Dr. Ghularn Saeed

Dr. Kazem

Hamidullah Natig

Dr. Sanaul Hag

Haji Ibrahim

Khal i 1-ur-Rahman

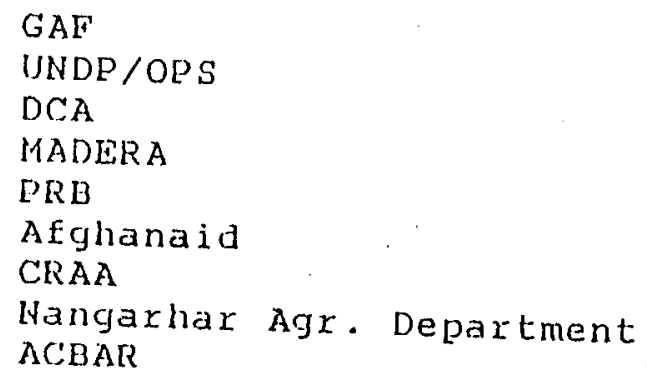




\section{A C B. A R \\ VETERINARY SUB-COMMITTEE \\ Minutes of the meeting held on Tuesday. 21 Sep., 93}

I. Minutes of the previous meeting:

Approved.

II. Discussion on the request of Nangarhar Agriculture Department: The Veterinary Sub-comittee sald that the issue of helping the Government clinics under NGOs policy may not be practical as per the present situation. The alternative solution could be the establishment of an independent clinic by one of the NGOs to provide', veterinary services to the needy farmers. The chalrman of the committee also suggested it would be better if a delation from the sub committee visit H. E.the Minister of Agriculture, Islamic state of Afghanistan and the related officials of the veterinary department. The aim of the visit is to brief the government high ranking offlclals about the activities of NGOs in the veterinary sector and thelr coordinated implementing policy.

\section{II . Need to having Microscope in veterinary clinics;}

UNDP proposed if there is need to provide microscopes to the VFUs. Some agencies said that it might be difficult for the staff of most of the clinics to use microscope properly and be able to accomplish the proper diagnoses without upgrading their professional skills. The chairman sald we need to have a clear objective so that for what for what purpose we wanl: to add this costly peace of equipment, glassware and reagents to the inventory of the clinics, to establish a laboratory at provincial center or on zonal bases to serve as the epidemiology cell would be a good idea. Majority of the NGOs are of the oplinion of establishing the zonal or provincial center laboratories.

It was also suggested to use microscope in a joint-diagnostlc purpose (diagnose of some human diseases such as malaria in addition to animal samples).

IV. Suggestion on continuation of the work of the Technical

\section{Committee;}

The technical committee for the evaluation of the veterinatians NGOs intend to hire did not meet for the last few weeks because of some concerns. UNDP\OPS said that the work of the committee has been found effective, it was emphasized that the committee should resume its tasks as before.

v. Report on outbreak of Thellerlosis in Paktia, Nangarhar and some other provinces:

It was reported that cases of Theilearia, a blood parasite, were seen in Nangarhar with some mortality in Hadda farm of Jalal Abad. It was suggested that the necessary medicine to treat the 
disease should be provlded by the NGOs to the VFUs.

VI. UNDP evaluation of BVWs:

UNDP/OPS monitoring team came from Ghazni recently and found the GAF training of BVWs' very efficlent. The ldea of having mobile BVW trainers team will be discussed in the next veterinary subcomittee meeting.

The attendants:

Dr. Hussaini

GAF

Dr. M. Halimi

DCA

Dr. Kazem

Dr. Sanaul Haq Ahmadzai

PRB

Dr. A.A. Nassri/ Dr. Mehraban

CRAA

Hamidullah Natiq

UNDP / OPS

Khalil-ur-Rahman

Afghanaid

ACBAR

The agenda for the next meeting will be:

I. Approval of the agenda

II. Minutes of the previous meeting.

III. Announcements.

IV. BVW Mobile Training -NGo report. 


\section{A $\quad$ C $\quad$ B $A$ A}

\section{VETERINARY SUB-COMMITTEE \\ Minutes of the meeting held on Tuesday, 5 oct. 93}

\section{Approval of the agenda:}

Approved.

II. Minutes of the prevtous meeting:

Page 1, 1tem IV should read "The Technical Committee for technical evaluation of the veterinarians NGos want to recruit, did not meet for the last few weeks because of some concerns."

\section{II . Añnouncements:}

A) . UNDP said that MADERA does not follow the courdinated policy as per the sale of medicines at $100 \%$ of the actual price paid by the NGOs at their respective VFUs. This has been creating problems for the clinics of other NGOs working in neighboring areas. CRAA said that there are complaints about unavailability of medicine in MADERA clinics. It was said that MADERA offers lower price, compared to other agencies, but can not supply the medicines at quoted price. The farmers are refered to the clinics of other NGOs, they expect the same price quoted by MADERA. UNDP said that MADERA staff are even not aware of the $100 \%$ policy:

It was suggested to send a copy of the minutes of this meeting to EEC so that they can also take notice of this problem.

B) DCA was told by UNDP if possible to supply the needed vaccines for other NGOs. DCA asked the NGOs to place the demand list so that they can look for the possibility if they can make the supply. The Director of DCA is planning to go to Quetta next week and will negotiate the supply possibility with VRI -Quetta.

C) DCA has mapping facility. The interested agencies can submit their offers.

IV. BVW evaluation:

In the previous meeting. It was discussed that mobile BVW lxaining teams should be organized. This could be done by individual NGo or as a joint training team of the NGOs for a region.

In the same meeting it was questioned if there is need for further BVW training. GAF said that they are in contact with UNDP to get fund for 2 to 4 trainers. Number ol BVWs trained in Kapisa, Parwan and Kabul seems to be inadequalie.

DCA has proposed the funds for 2 trainers to its board of management they might know by the end of the year whether the proposal is approved or not. 
DCA said the BVW training cost should be compared with that of paravets. The chairman said as far as the cost is concerned BVW training is a yood accomplishment even if half of the BVWs stayed at work.

Any other business:

A) ARC representative once again participated in the subcommittee meeting. Since UNDP fund was stopped on ARC, the agency handed over its veterinary clinics in Logar to DCA and GAF. The clinics in Jaghori and Malistan were kept by ARC for the possibility of securing the funds from other donors.

In May 9.3 both cinics re-started the activities, and a veterinarian was hired to supervise the clinics. Previously, each clinic had 6 paravets the number have been reduced to 3 paravets per clinic.

B) ARC said that Enterotoxemia is seen in Ghazni. To the experience of ARC they claim that the enterotoxemia vaccine does not produce immunity in adult sheep. ARC was advised to apply. the boosters the problem might be solved.

Dr. Hussaini (chairman)

Dr. Nasseri

Dr. Kazem

Dr. Ghulam Mohammad

M.van den Dool/ Dr. Halimi

Rahmatullah

Dr. Abdul Zahir

Khal i 1 -ur-Rahrnan

GAF

UNDP

PRB

ARC

DCA

IRC/HERC

CRAA

ACBAR 


\section{$A C D A F$}

\section{VETERINARY SUH COHITTTEE

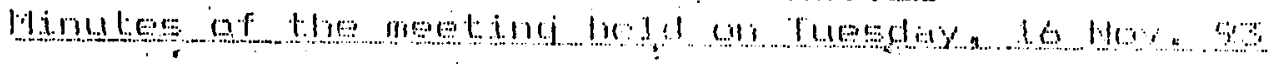

Approval or the agenda:

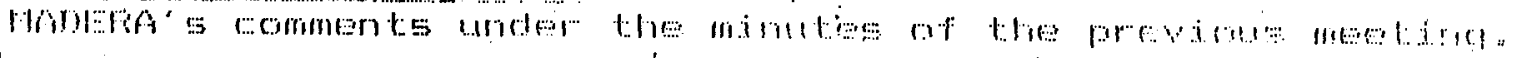

\section{Minutes of the prexions nereling:}

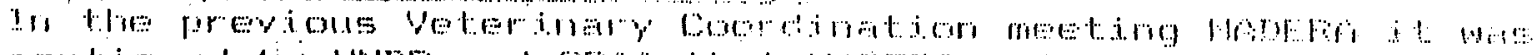

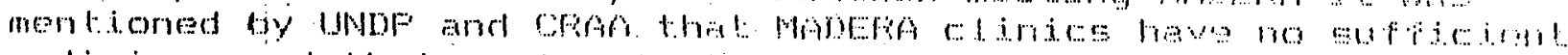

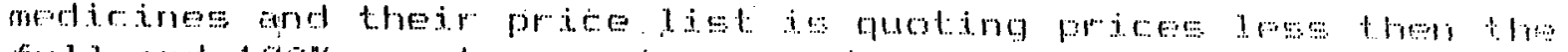
full and $10 \% \%$ purchase price.

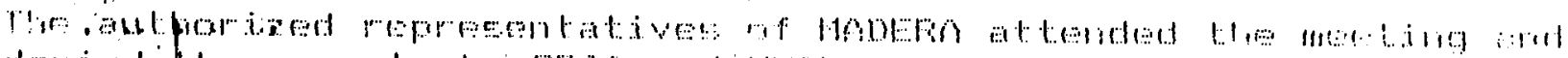

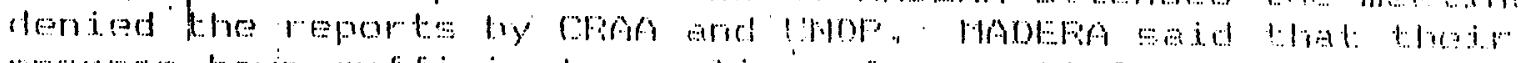

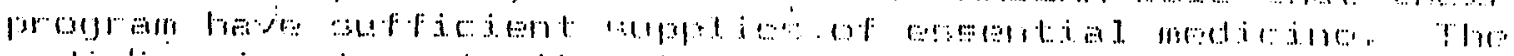
medicine is wiven to the whose ar a litele under loge and the

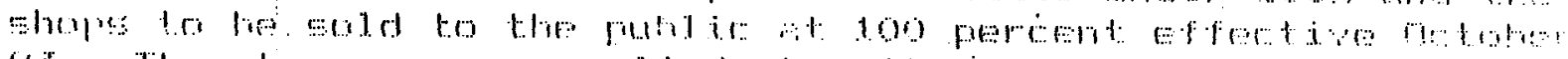

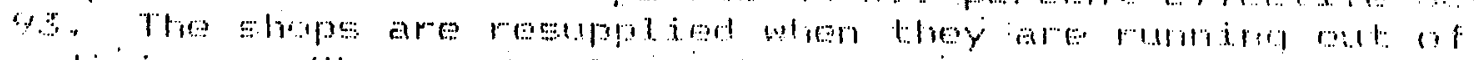

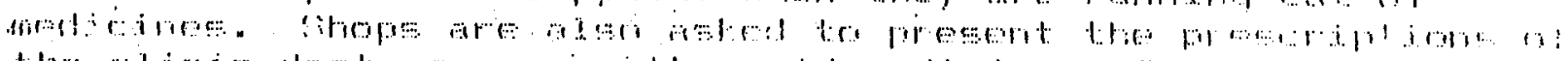

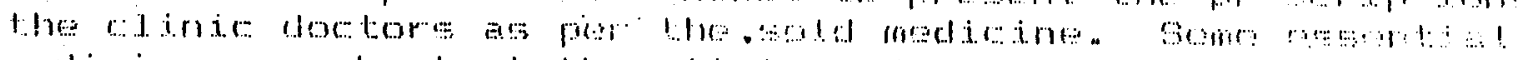

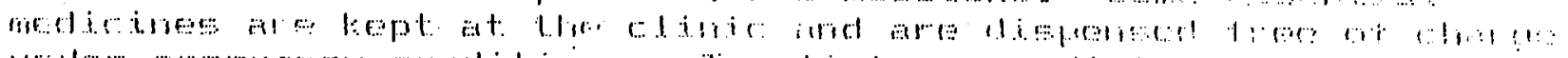

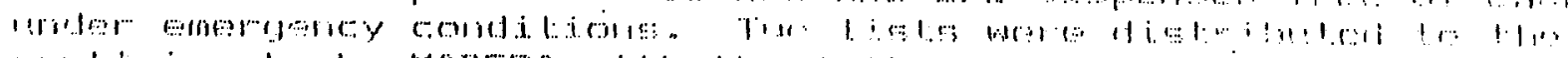

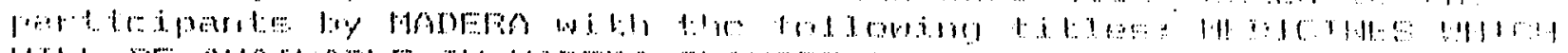

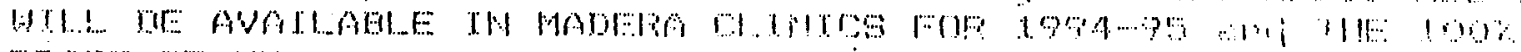

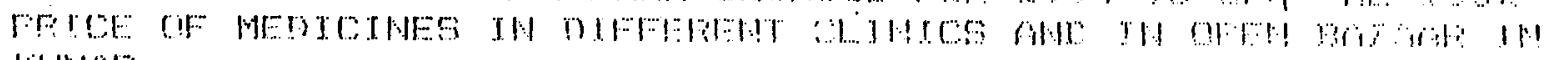
HIIAT:

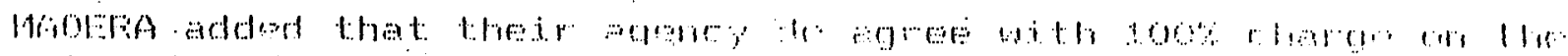

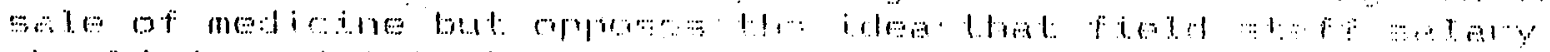

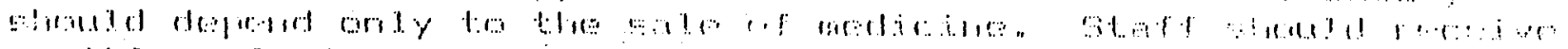
mon!hly sa do

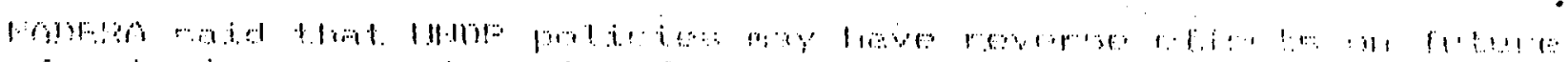

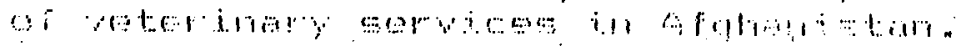

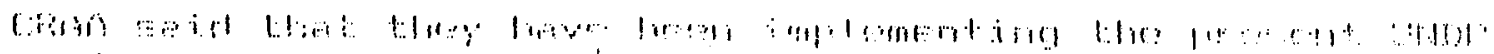

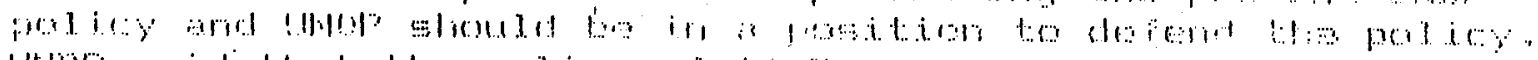

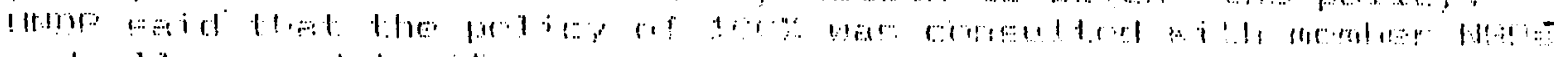

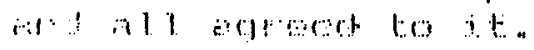

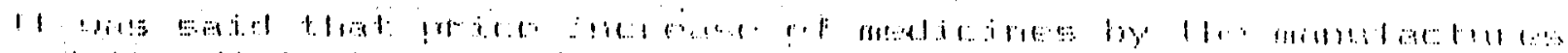

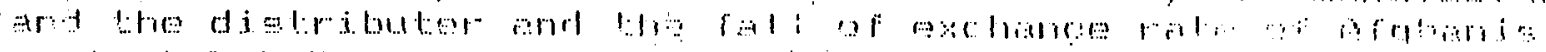

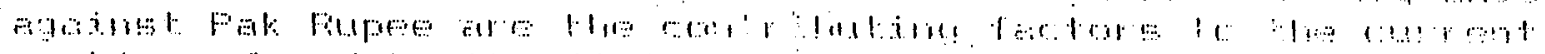

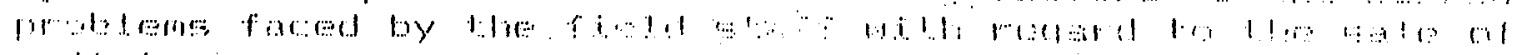

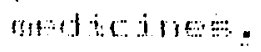

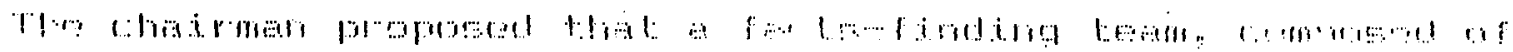

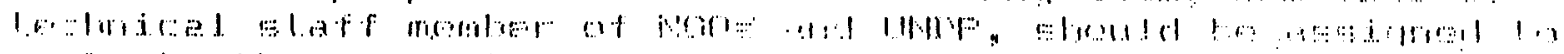

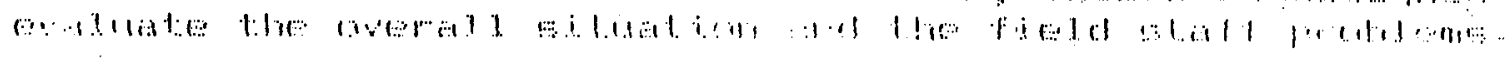




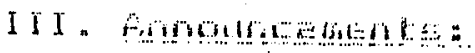

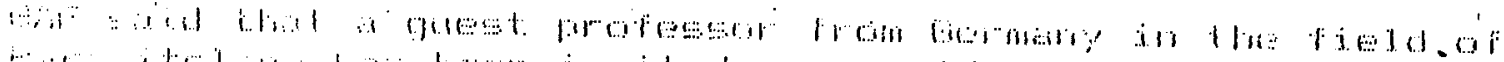

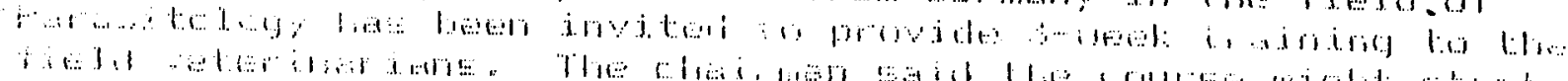

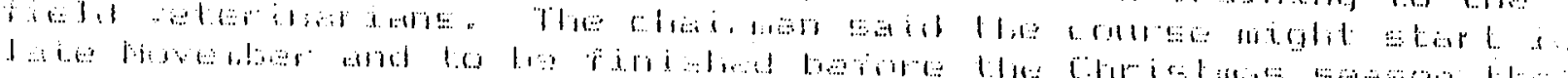

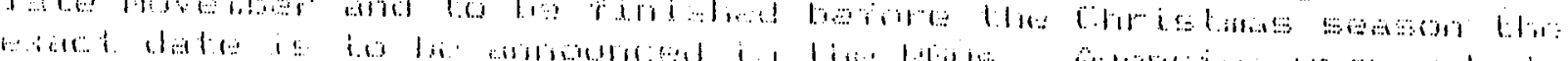

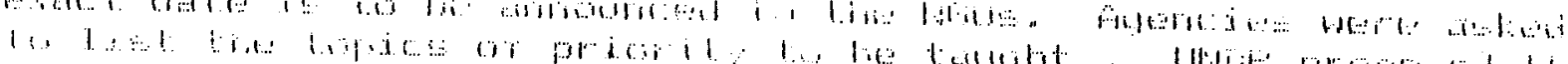

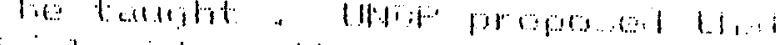

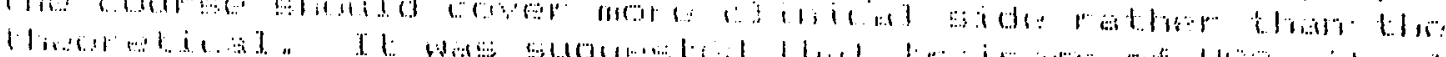

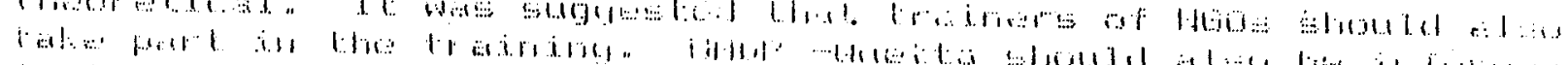

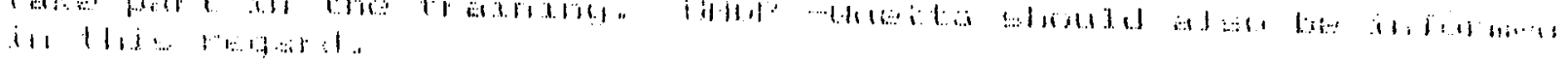

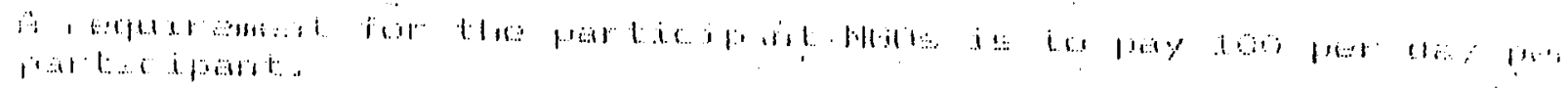

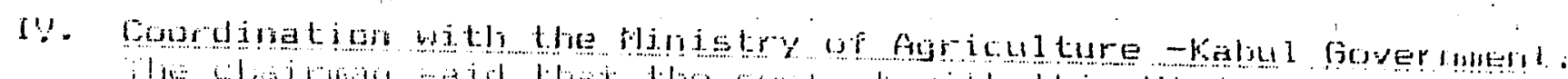

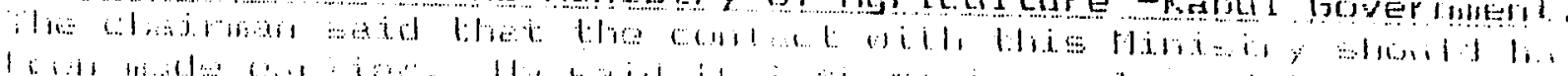

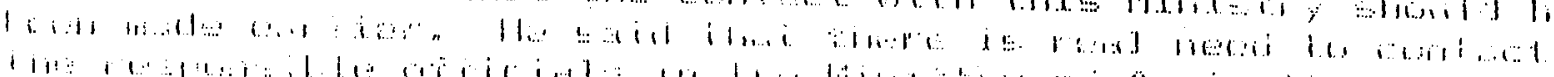

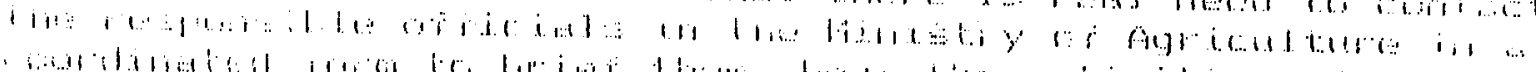

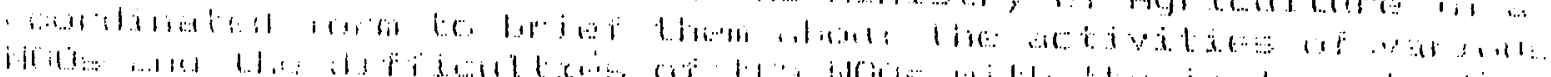

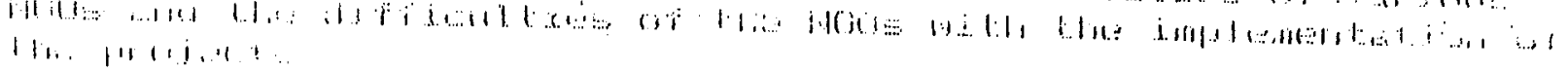

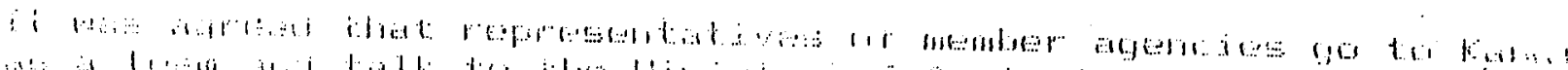

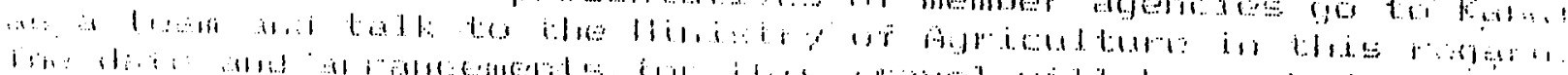

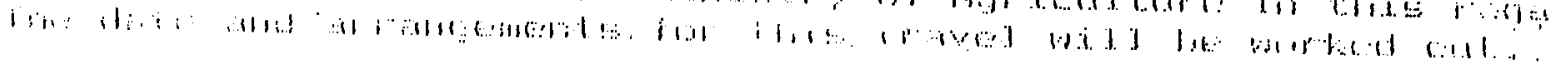

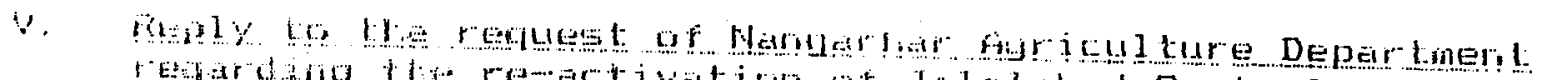

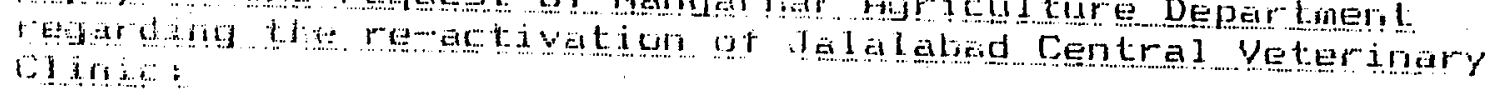

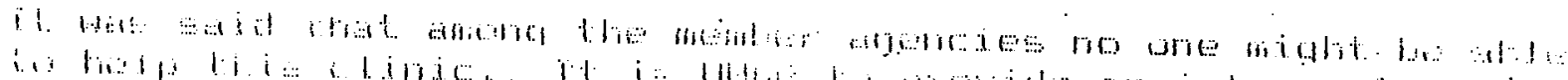

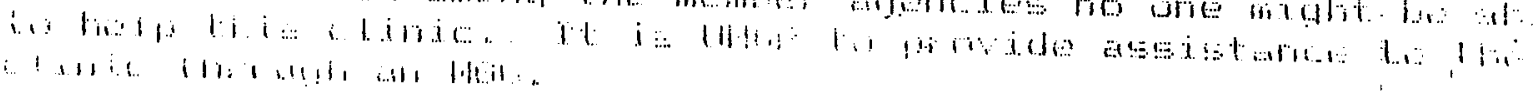

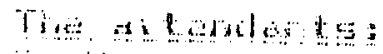

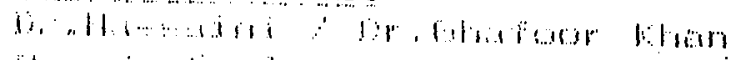

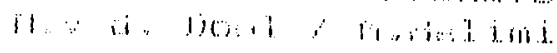

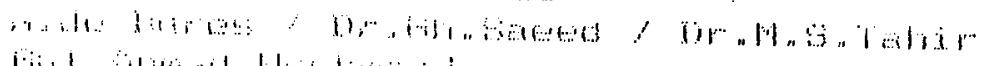

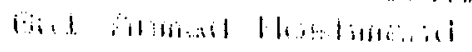

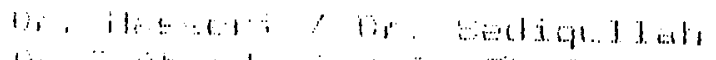

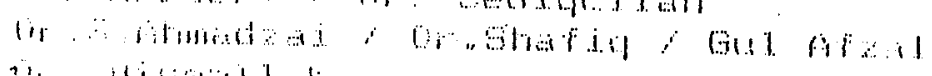

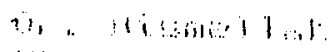

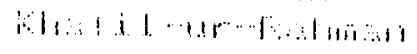

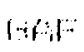

TiCH

Mitrentes

(n)

III)11\%

लrim

IIII

GQBका:

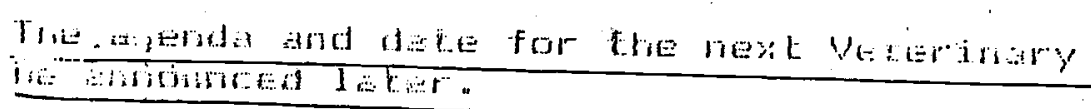

Sub-commit tee inckting wi

\section{6}


VETERINARY SUB-COMMITTEE
Minutes of the meeting held on Tuesday, 7 Dec. 93

I. Approval of the agenda:

MADERA commenls under AOB.

II. Minutes of the previous meeting:

$\Lambda$ few repeated/unnecessary words were deleted from the first and second paragraphs of item II, page one.

III. Announcements:

A) MADERA reported outureak of CCEF in Vegal and Eech valleys of Kunar frovince. Vaccine was prepared from the lungs of the affected animals, aboul 30,000 dozes was prepared at MADERA's rield laboratory at nsad Abad and applied to the animals in the area with no side eflects and prumising results. People of the area are demanding more vaccine of prepared from the goat lhat vacicine for goats should be prepared frum the gheep lunis and vaccine for sheep should be species specific.

MADERA reported some fighting in Barikot and said that the i tuation wais of energency nature. The reaisun was disagreement with the appointment of the district
daministration.

D) Dr. Bram Schruder, DCA board member, has said that spome one from Worla Banl: who ha: extensive knowledye of the velerinary services and animal husbandry in other countries is current:1y going through, has shown the willing afghanistall conduct: a seminarian probably next ow the willingness to II is information may serve as a too June or May in Peshawar. the NGOs inplementing veterinary pro the future role of how the various donors e The Chairman said lhat il is pos this sector effectively. as to lhe evaluation of ho possible to draw a conclusion coordinated policy of the nampact of the current

Euture plans and policies NGor and recommendations for the Afghanistan, to be afforifor veterinary services in It was said thal a comilable and as well sustainable. representatives should work, as the organizing folluwing NGos the anticipated seminar:

$\begin{array}{lll}- & \text { GAF } & \text { Dr.Hussaini } \\ - & \text { ERA } & \text { Dr.Schruder/Martin/and or Halimi } \\ - & \text { CRAA } & \text { Eng.Kabir } \\ - & \text { ACBAR } & \text { Dr.Sanaul llag Ahmadzai }\end{array}$

It wass alio mentioned that an authorized senior level representative from Lhe Vilerinary Department of the 
88 
Ministry of Agriculture - Kabul and the UN agencies. should be invited to the seminar.

C) GAF said that a two-week clinical course on clinical aspects of blood protozoans in farm animals will be conducted by a German Professor. The course will start on 22 January, 1994 in Peshawar. Agencies interested to participate can contact GAF main office for further information.

GAF also plans to organize 8 sessions of a three week refreshef course in Khost, for the Eield veterinarians of NGOs:- This course will help to upgrade the professional skilis of the field staff in the areas of clinical

diagnosis, internal medicine, epidemiology and parasitology. The. course will be conduclea by the ex-staff of the faculty of Veterinary Medicine, Kabul University, Dr.Nasimi and Dr,Gulistani.

[V. Alternative sourcés for supply of medicine:

The chairman said that soon after the application of $100 \%$ cost recovey on the sale of veterinary medicines, there was a price increase on most of the veterinary medicines by the manufacturers. The soaring prices has created difficulties in the field. Therefore, a coordinated solution should be sought to solve this problem.

Director of PRB had a trip to England recently. He visited some firms and companies producing veterinary medicines and instruments. Although the prices of medicines and instruments were relatively high as comparea to the ones available in pakistan but they were of better quality. Most of the Vru staff have been complaining about.the poor quality of the instruments. currently at their disposal. It was recormended if UNDP can helip the procurement of the necessary instrumentsof good quality for: the VFUs.

IV. A trip to Kabul to contact the Ministry of Aqriculture:

The matter was once again brought to the attention of the member agencies. The chairman said that it is better to contact the Ministry of Agriculture at the earliest possible time. Since the Director of DCA will be leaving the country, it was suggested to postponed the visit till his arrival.

It was emphasized that the NGos should have list of their veterinary projects, to be sulmitted Lo the Ministry of Agriculture.

V. Any other business:

A) The UNDP monitor returned from a monitoring mission from Kunar and reported that an employee of one of the NGOs who recently visited the VFus in kunar province has created 
- some misunderstandings among the field staffs of the NGOs working in that province. The said representative has falsely introduced himself to the local shopkeepers and Iield staff of other NGOs as the representative of UNDF and ACBAR. The UNDE monilor and the Director of CRAA strungly prolested this acl.

B) MADERA said, their velxiharian recently visited Laghman and observed expired medicines at some shops in local bazars. MADERA suggesled that some preventive measures should be sought through the provincial authorities. But other subcommittee members said that it might be out of control of the authorities to solve this problem at this particular time.

The attendants:

Dr.llussaini/Dr. Ghafoor/Mohd Mehdi GAF

Dr. Eblahimi

UNDP

Dr.S. Ahmadza i

Dr.Ghularn Saeed/Dr.H.S.Tahix

$\operatorname{CR} \Lambda \Lambda$

Dr.Mohibullah Halimi

MADERA

Eng. Kabir

DCA

Eng. Esmatullah

PRB

Khal il-ur-Rahrilan

$\triangle D A$

ACBAR 


\section{(1) $C \| \cap 11$

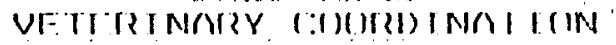

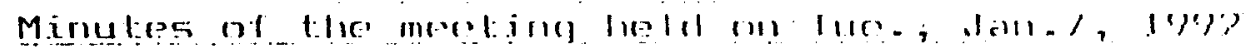

At tendants:

Dr. Neil Chesterton (chajrman)

Dr.M.Hal imi (rep. chairman).

Sajed

Dr. Daud Shah

Dr. Sayed Arja

Dr.Ghulam Saeed

Khal il Fahman
Comprov

nein

APO

T'RIB / GAFF

AIBI

MADFren

nishor?

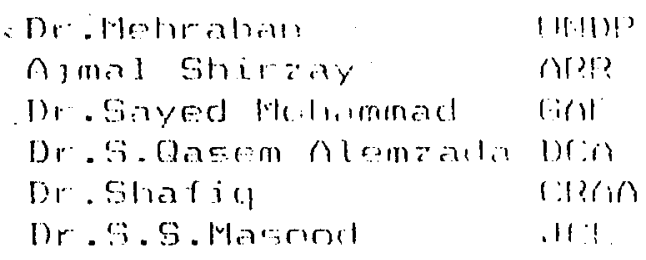

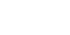

\section{Announcements:}

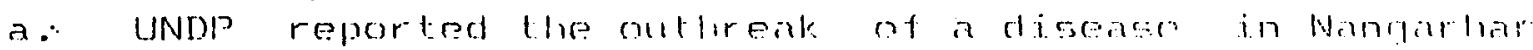

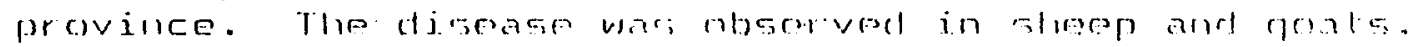

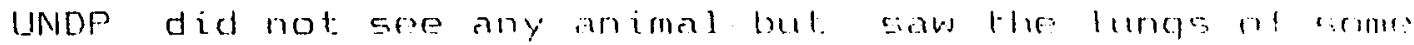
of the affected animals. The lenge had light amel dart: areas (marbling). Dortors roported that therr mas

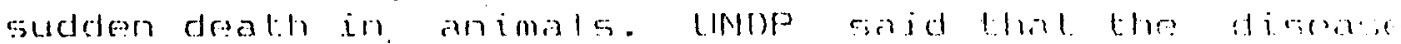

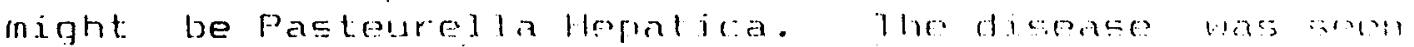

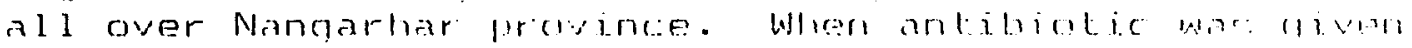

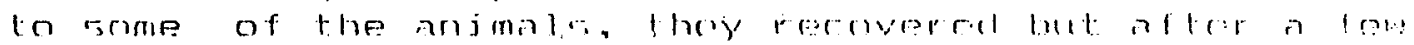

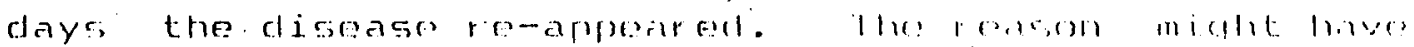
been inadequate lenght: of treatinent.

A DCA field workar also reported a similar disensor lust. said that antibiotics were not effective. It las said that CRAn wjll torjog somples from kumar and Nenclorhar to Peshawar to he? ramined.

b. At the beginning ol Decomber 1.791, kochies from lama Daka of Mangarhar province informed lehad lonsultime

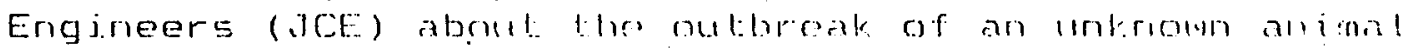

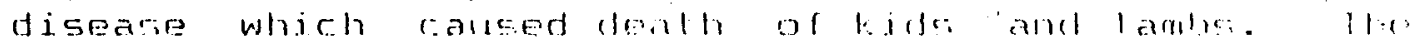
disease had not seren in the ares hefore and il migh!

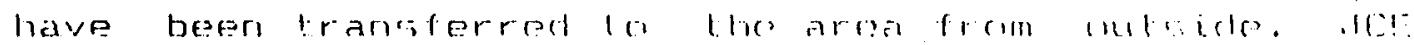

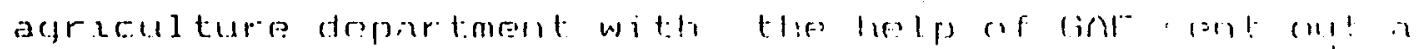

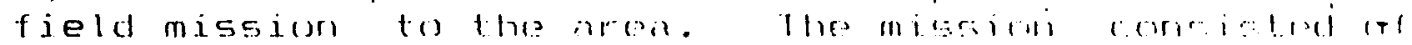

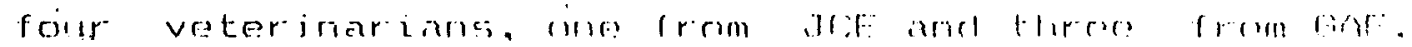

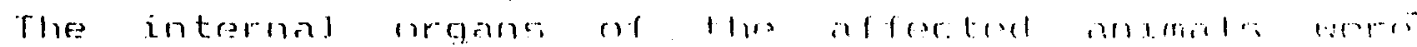

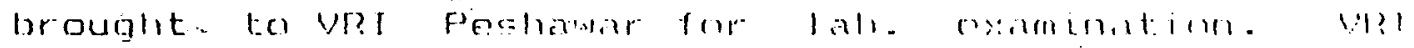

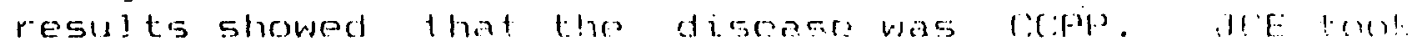

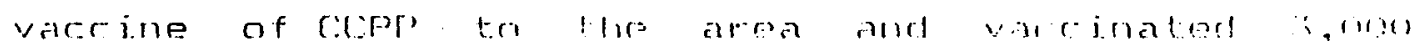

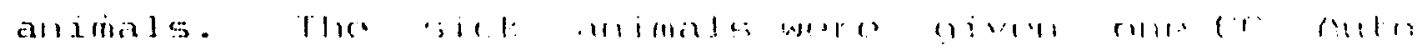
vaccine, as wrell taramy ine la or licmbial ir.

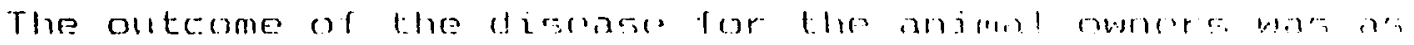
follons:

Sheep

Goat:

K.i il

$5.0 k$
15
25
$4: 3$

$110 \mathrm{alh}$

$\therefore$

?

16 
c. Afghan Relief and Rehabilitation (ARR) mjssion had a trip to khost from 9-16 December 1991. ARP reporled that many chickens died eating wheat seed treated wilh chemicals in Bak and Gurlute sub-districts. APR ilso said that foot and Mouth was a najor cow diciess im lim. area. FMD is common all over Afghanistan. The vaccine produced in Kabul or imported from Russja was very effective. Some of the koochies still get line ir FMD vaccine from Jalal abad.

ARR also reported that in Gurbuz sheep were dying. The lungs of the sheep were turning dark. According to ARR, some respiratory diseases are common in shech and goats in Fall season in the area.

d. Afghan Planning Agency (APA) hacl a trip of wardat a week ago. APA reported that FMD was common in wardal.. There was no good trealment of this disease. APA also said that sheep were swelling and dying over night. Need for chicken vaccination was felt in Jaghalion.

II. UNDP report alout trip of Nangarhar:

UNDF mission had a trip of Nangarhes prowince from 31.31 of December $1991 \ldots$ The mjssjon visited the clinics of orn. (n) and CRAA in different parts of the province. The pugrams were running well. Charging policy was well applied witlin the community. Commanders were very cooperative will lihe veterinary programs. Most of the clinics (especially in warm areas) didn't have encugh medicine. DCA had a good medicine program in which the medicine use is controllod hy the doctors.

The BVWs trained by GAF were present in the area and thry were working well. DCA and CRAA still do not have Buws: in Nangarhar.

Record keeping was very poor. There was no daily atemclance record of the personnel. The coordination suggested thel a daily attendance record should be organjzed for field stafi.

UNDP said that a lot of boards of different projeclis by different NGOs were seen along the roads but there was rio sign of the activities of most uf the projects. LNDP is in favor of boards ta show the existence of a project jin a location. The board should also show the funding agronc:.: GAF has distributed boards to its projects.

UNDP mentioned that some vet staff haves issued two differenl of receipts. It means that the animal owner wag given a different receipt to the original kept at the cljinic. Some animal owners said that they did not receive any receipt at all and they were charged higher than proposed. 
UNDP expressed its concern over the professional linowloctge of staff. Most of the technical staft had very poor knowledge. NGOs should take some strict ineasures recruiling field personnel. Each tecmical staff in the field at losat should have a copy of the BVWs inanual.

\section{I . COMDEV's Poultry Proposal :}

COMDEV suggested a proposal that would qujckly increase the genetic potentail of the poultry population of a village flock. In this proposal only cocks would be introduced to the village. All village coctis would be slaughterso and replaced by cocks. of superior genetic quality. This would have a number of benefits.

A. Every chicken born would inherit $50 \%$ or the genes of the cock.

B. Every chicken born would inherit gones from the local hens (hardiness, resistance tn loral)

C. Fairly cheap to implemrnt.

D. Rapid genetic improvement of the flock without: change of local husbandry techniques.

Discussion suggested possible reluctance by lowal farmers to kill off big cocks only to he replaced by two or three month old cocks. Otherwise there was interest in the proposal.

The next vet = Coordimation moretno will log hold

at $\theta=15$, Tuesdiy, Jan $.21,1992$

The AGENDA is:

I. Announcements

II Report about the outbreak of disease in Nangarhar

III. UNDP report about 1992 fundirg

IV. COMDEV report on their projects 
94 


\section{- 95}

\section{$\cap: \| \cap R$

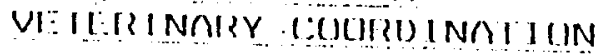

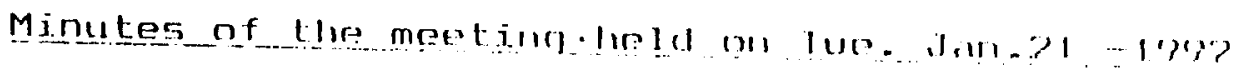

nttendants:

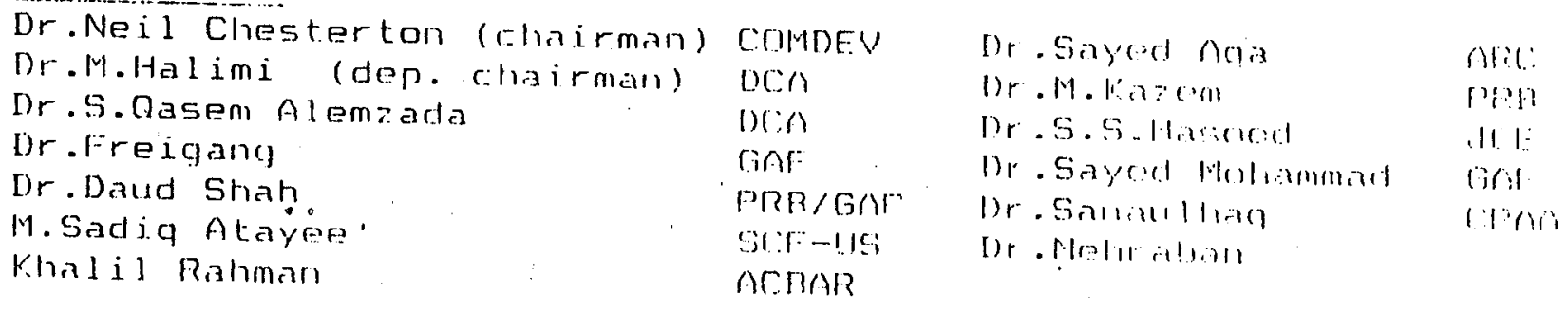

I. Mmmonorment:5:

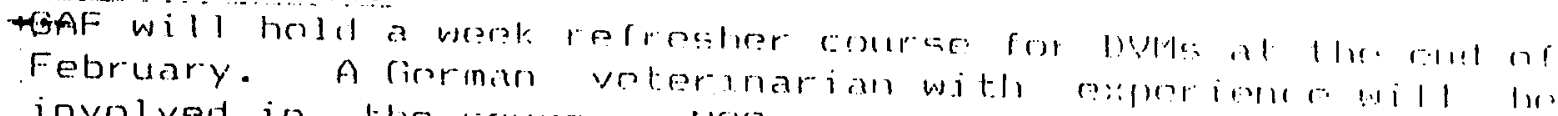

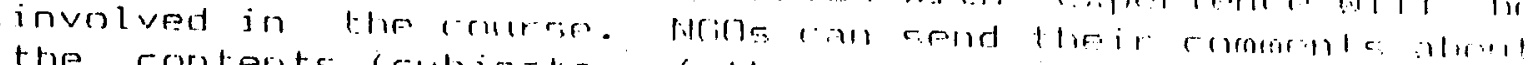

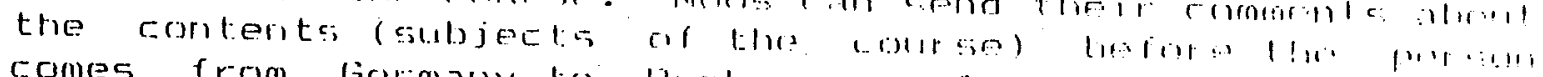

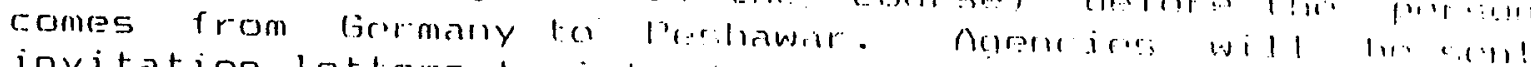

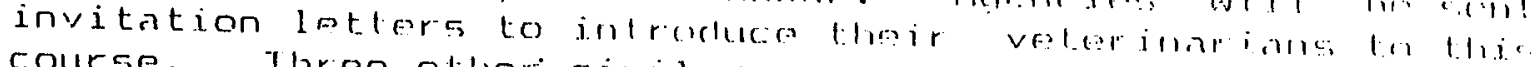

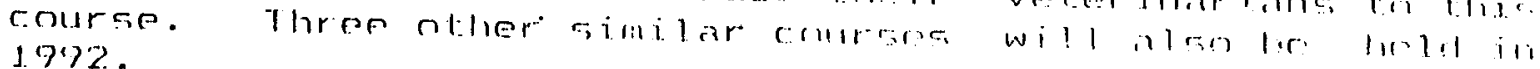

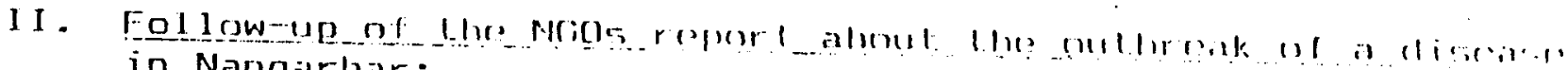
in Nangarlhar:

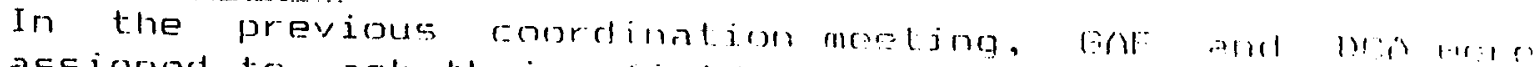

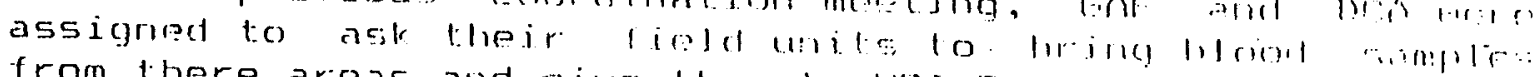

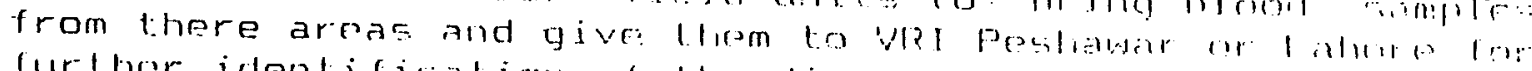

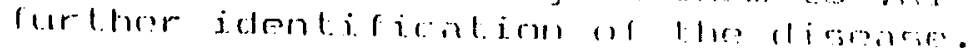

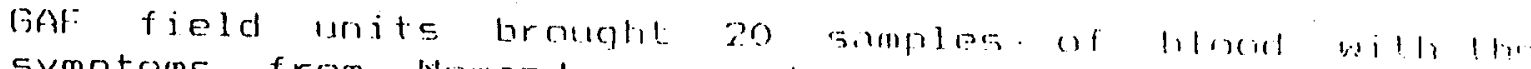
symptoms from Momandara and sant lom alome will:

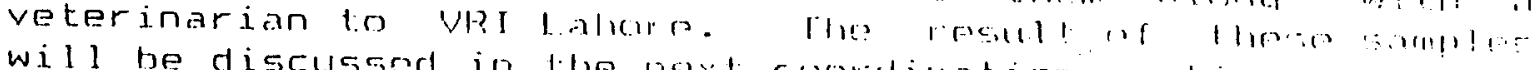

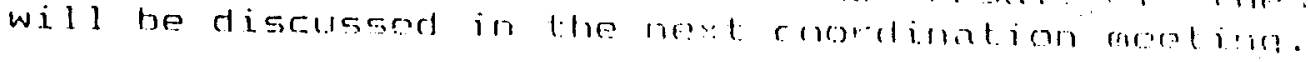

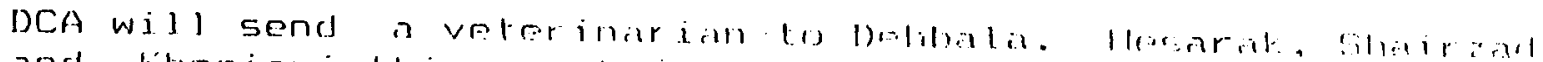

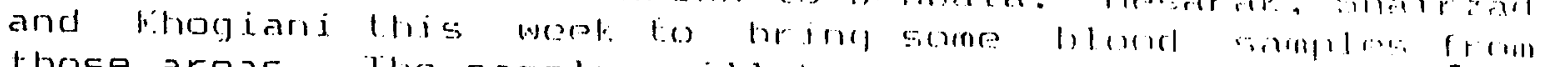

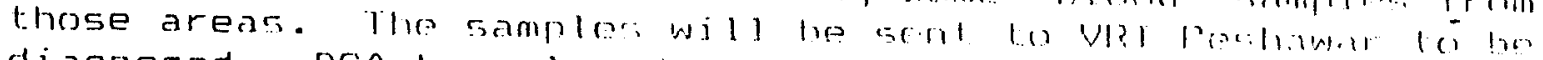

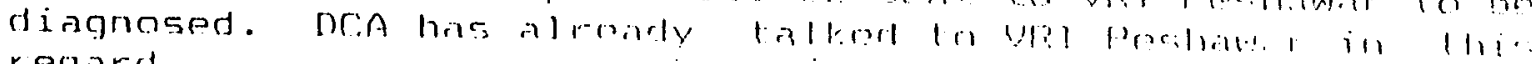
regard .

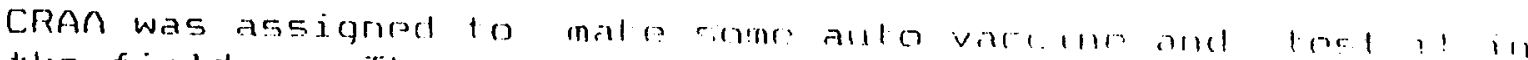

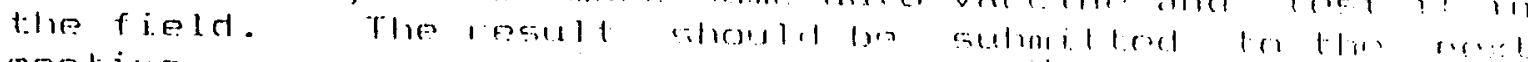
ineeting.

III. UNI)P report almon! log? fmelimn=

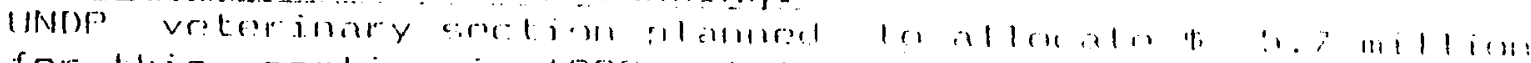

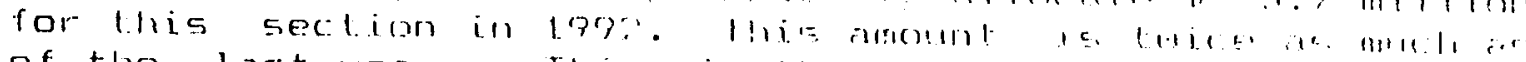

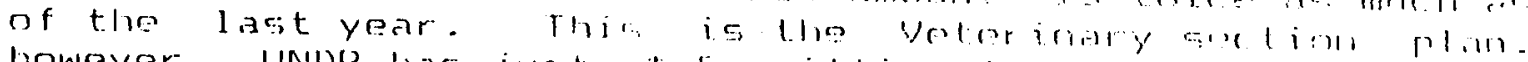

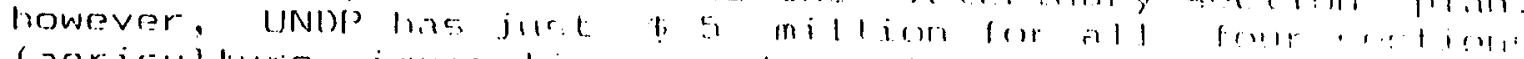

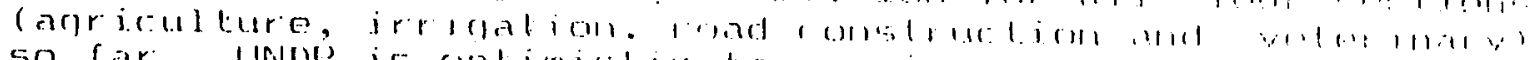

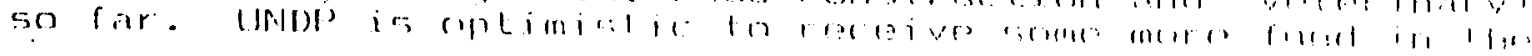


near future. It was also stated that if new fund do not come, selected projects will be funded. UNDP added that hol.s projects of an NGO will not be funded until the on-uring ones are certain of their funding.

UNDP has established a branch in Mazar-j-Sharif. At present: no veterinary activities are carried out by Marar hranrh. But in case of shortage of fund to Peshawar litanch, (llill)p Mazar-i-Sharif can assist runding projects in northern provinces. Another UNDF branch will soon open in Macklad, Iran. This branch will also provide fund for the velerinary projects in western parts of Afghanistan.

FAO Kabul has been planning some veterinary giervires especially för central and northern parts of Afghanistan.

IV. COMDEV report about its probiects:

COMDEV reported on the difficulties they have hind in establishing vet. clinics in Badakhshan. Combev has implemented one $V . F . U$ in Jurm, a subclinic in Baharak and a V.F.U in Yaftal. The main constraint has been the difficulty in finding DVMs or vet. assistants to work in lie North. This staffing problem delayed the implementation of COMDEV's second clinic until December. The difficulties of communication with Badakhshin during the winter has left. COMDEV uncertain of how activities are going at the Yaftal clinic.

V. Any other Business:

JCE is studying the possibility of providing artificial insemination in some parts of Afghanistan. [t will be similar to the program carried oul by liabul. According 10 this plan, some centers will be established first in finct and Ghazni. Each center will be sent 2 bulls from Pakistan. The fresh semen received from these bulls will be given to BVWs to inseminate cows of the villagers. The semen will lie given to the BVWs either free or for a small amount. of monev and the BVWs can charge animal owners for a hidher ancunt.

The Coordination advised jCE to study the program carefully and find out the esipense and outcome of the project. 


\section{7 \\ A C $B A R$ \\ VETER INARY COORD INATION}

Minutes of the meeting held on Tues., Feb.4, 1992

\section{Attendants:}

Dr.Neil Chesterton (chairman)

Dr. Halimi

Dr.Sanaul Haq Ahmadzai

Dr.Daud Shah

Dr. Housaini

Shahzada Lais!

COMDEV
DCA
CRAA
PRB/GAF
IRC/RPA
L.B.I.

Dr. Mehraban

Dr.Kazem

Dr.Q. Alemzada

Dr. Shafiq

Dr. Sayed Aqa

Khalil Rahman
UNDP

PRB

$D C A$

CRAA

ARC

AC BAR

I. Agencies report on their findings from VRI and field:

:CRAA wä́s assigned to send a team to the area to apply auto vaccine to sick animals. The team composed of two doctors and an assistant vet. and a paravet went to Nangarhar province to carry out the survey within the areas of its no signs of . According to the report of the team, there was no signs of CCPP and Pasturellosis in those areas.

Only two samples (lung of sheep) were taken from baishifiloc and were sent to VRI Peshawar. Thie result was:

a. Lung of the mature animal - Hemophilus isolated.

b. Lung of young animal - no growth obtained.

The team got directions about the preparation of auto vaccine from VRI Peshawar and along with the required instruments went beck to the area on the 2nd of February. Shadal, Abdul Khail, Kandaro, Miangan and Tara Khail areas were surveyed. In Pekha a lung of a goat slaughtered just 2 hours ago was taken. and auto vaccine was prepared on the Teramycine to 150 she vaccine was given with and without side effect for almost. Of an animal owner. There was no auto vaccine. Becuase 1.2 hours after the application of animals were also vaccinathere were no side effects, other The Coordination watch the effect of auto CRAA to go to the area and closely

It was suggested that a small trial should be done to test the autol vaccine further. It was also advised only to prepare auto vaccine from the sick animals of the same flocks in which the vaccine will be applied.. Discussion wil.l be held with VRI Peshawar to find out if they have any serological tests on the use of auto vaccine.

GAF has not received the results of the samples sent to VRI Lahore. VRI will send the result by mail. 
DCA has sent people to Nangarhar to collect samples. These samples will be sent to VRI Lahore.

\section{Any Qther Business:}

IRC gave training to 24 BVWs for a period of 5 weeks (Dec.10 - Jan.15) in Chamkani. Ten days more refresher course will be given to these trainees. There are some more candidates for BVW program.

BVWs manual has almost been finished and the money for printing will be shifted to DCA. DCA will print the number according to the request of NGOs and then at end all of the costs per copy will be received from the concerned NGOs.

Subjects for GAF refresher course were selected by GAF and COMDEV and it.will be sent to the person who is supposed to teach the course. This person will be in Peshawar on 24 th of February. 


\section{9 \\ $A \subset B A R$ \\ VETERINARY COORDINATION}

Minutes of the meeting held on Tuesday. Feb.18. 1992

\section{Attendants :}

Dr. Neil Chesterton (chairman)

Dr. Wassink, Leon Van Mulken

Dr. Sayed Mohd, Dr. Ghafoor, Dr. Daud Shah

Dr. Daud Shah, Dr. Kazem

Dr. S. S. Masood

Ajmal Sherzai

Dr. Ghulam Saeed

Eng. Shahzada Lais

Khalil Rahman
COMDEV

DCA

GAF

PRB

JCE

ARR

MADERA

L.B.I

ACBAR

\section{Announcements:}

a. BVWs manual was sent for printing.

b. DCA has printed some posters as part of its veterinary extension activities. About 300 copies (10 pages) are available at DCA. Interested agencies can get them from this organization.

II. Suqqested program for GAF refresher course:

The course will start on 26 February in GAF training center. A list of the topics proposed by the lecturer and then selected by Dr. Sayed Mohd and Dr. Neil was distributed to the attendants of the meeting. Practical sessions will be involved in this course. The course will last for ten days.

III. NGOs latest information on their investiqation about disengese in Nangarhar :

GAF has sent 20 blood samples to VRI Lahore. The result of seven samples arrived showing no pathogens present. The other samples are under process and will be reported at the next meeting.

DCA team went to Dehbala, Shirzad and some other parts of Nangarhar province. The team interviewed 29 farmers including 15 sheep owners, 12 goats and $2 \mathrm{mixed}$. The resull showed that young animals were more effected. A combination of antibiotics and anthelmmentics was effective in the animals. Samples were taken. Some will be sent to VRI Peshawar and some to Lahore and some will stay in DrA refrigerators. 
100 
IV. JCE presentation about HONEY BEES :

JCE is planning to work on the propagation of honey bees in some parts of Afghanistan. A brief presentation was given about the importance of honey bees in family economy and its background in Afghanistan. The detaail of the presentation is includeed in a separate sheet which will be sent with the minutes of this meeting.

The coordination was interested to: receive some more information about bees. It was mentioned that Mr. Wasim Ludin, the director of AHSAO, has made a lot of experience in this field. He will be invited to participate in the next coordination meeting.

v. Any other business:

It was requested that any agency or individual who is part of the agenda and can not attend the proposed meeting, send early notice to the coordination at ACBAR. 


\section{HONLYY BERS PROGRAULE}

- Honey bees are mostly living In holes of walls, trees stones etc. These holes are pocked by man inorder to obtain honey, which cause bees death or escaping, while some people hived them with out knowing bee biology, because there is nelther any beekeeping books nor cnough beekeeping skilled people avalible in Afghanistan. Afghanistan beekeepare work with bees traditionaly, disterb bees 1 ife, that reduce thler product and cause death or escaping of bees.

As a matter of fact the amount of honey lift by the owner for bees eating in winter time some time due to some reasons, this amount of honey is not enough to pass winter, or some time bees consum thier fools faster, that is to say, thier food finishs at the middle of winter, so beekeepars should realize that and feed bees inside the hives with certian amount of sugar syrup artificlally in the propar time. If they lon't ferd bees in propar time, they would die, because of food shartage. Unfortunatiy most of $\lambda$ fghan beekeepars clon't know bees artiflcial feeding and loss more then 50\% of thier hives in winter time, mostiy in long winter.

During war period $70 \%$ of bees have died, or escaped, becaus of frequent bombing, sound of lifferent weapons and people migration.

lloney bees have aclive role in pollination, which up-grad garden production. Unfortunatlly $\lambda$ fghan Gardeners don't know anything about: that, even they refused bees.

Beekeeping started by Afghan Agrlcultural minstry in 1963, which involved 900 hives of different species $(300$ Italian, 300 vafgazian and 300 local bees, hives). nfter. research on these bees, the rtaliall bees were accepted for. selling to farmars. $\Lambda$ limited number of hives to had been sold to people yearly, wich encouraged people in beekeeping. I'his source of: income during war time was destroyed and was not able to do so anymore.

Bees don't need everyday juspection by man for thler living and production. So everyone can have few hive in thier yeards or on the lop of thier building and work on it in thier lesior time to help thier famlly economy out of bees production (honey, wax, new nuclus colony).

- Beekeeplng in Afghanistan is not popular although there are enough honey surces avalible, so honey production is very 11 meted, therefor just some people use 1 t as a medicine, but people are fond of honey. If that sources of honey used by bees, the honey and frult production would Increased, and honey could be replaced with sugar, becaus sugar is also imported to Afghanistan. 


\section{3 \\ A C Q A $A$ R
VETERINARY SUBD-COMMITTEE}

Minutes of the meeting held on Tue., March 10, 1992

\section{Attendants:}

Dr. Neil Chesterton (chairman)

Dr. M.Halimi (assist. chairman), Dr. Gerrit Wassinik

COMDEV

Dr. Sayed Aqa

DCA

Dr. Housaini

ARC

Dr: Mitasoot

$I R C / R P A$

JCE

Dr. Mehraban

UNDP

M. Sadeq Atayee

SCF - US

Ajmal Shirzai

Dr. Sayed Mohd, Dr. Daud Shah, Dr. Zaker

ARR

Dr. Daud Shah, Dr. Kazem

GAF

PRB

Engr. Shahzada Lais

LBI

Khali'l Rahman

ACBAR

\section{Announcements:}

a. BVWs mannual was printed. It is ready for destribution.

b. DCA said that the Veterinary sub-committee has not been included in ACBAR annual report.

c. A letter from ACBAR to NGOs stated that the permits for commodities transportation into Afghanistan should be channelled through the Afghan Interim Goverment. The former procedure was to send them through the Commissionerate for Afghan Refugees which was taking more than 8 weeks. But, through the new channel it will take around 10 days. UNDP will contact the Home Secretary of Pakistan in this regard and the result will be reported to the next meeting.

II. Mr. Ludin presentation:

Mr. Lidin was supposed to give a presentation on honey bees but he could not come to this meeting. He will participate in the next meeting.

\section{II . Results of NGOs samples from URI:}

DCA representative took the blood samples to VRI Lahore to be tested for the diagnosis of a disease observed in Achine. According to VRI-Lahore, the test was applied to Guinea Pigs. Finally, after three days VRI said that they did not find any disease. It appears that, VRI-lahore is not interested in this type of work.

DCA said that VRI-Peshawar had links with Holland. DCA will ask Holland to provide facilities through VRI-Peshawar. It was said that measures should be taken to have complete 


\section{4}

laboratory facilities within the NGOs capacity in the future. UNHCR has donated lab. equipment. DCA has already received some.

CRAA followed-up the results of the auto vaccine applied to some sheep and goats in Achin. Out of 150 animals, 30 were sick and the remaining were in good condition. No side effects were seen.

CRAA field staff received the lung of a dead sheep from Barikot of Nangarhar province on 9-2-92. The sample was sent to VRI-Peshawar for lab. examination. The result showed KLEBSTELLA SPP and antibiotic use was advised. Veterinarians at the meeting quistioned the result

IV. UNDP report about trip to Kenia:

A two-week seminar regarding community veterinary health care was held in Kenya. UNDP-Peshawar representatives along with representatives from other countries participated in

The attendants were put in different groups and each group visited different villages. According to the representatives, the veterinary services provided by the Kenyan government were not enough to satisfy the needs of the people. All vet. services from the government were charged almost more than $100 \%$ on the community.

ITDG, a British institution has started community development programs in this country to train BVWs. Veierinary clinics are built by ITDG. There were shuras similar to ones in Afghanistan but well organized and program was working were almost $80 \%$ literate. The BVWs introduce voluntees effectively. Shuras are asked to the training program to be trained as BVWs. At the end of trainee. From the a kit of medicine is given free to each medicine and continue the services medicine BVW buy more system will enable the community to stand community. This Mastly wamen are invalved in BVW progr end of the program the group evaluated. The work of the results were discussed and Veterianry sub-committee of ACBAR was appreciated in the seminar. 


\section{A $:-B \cap R$ \\ VETERINARY SIIB-COMMITTEE \\ Minutes of the ineeting held \\ on Tuesday, March,24, 199 ?}

\section{Attendants:}

\begin{tabular}{|c|c|c|c|c|}
\hline Dr. & Neil Chesterton & COMIEV & Dr. Sayed Mohmmonad & $\sin =$ \\
\hline Dr. & M. Halimi (vice & $\mathrm{IDCA}$ & Dr. Mehraban & IINIOP \\
\hline Dr. & Sadiqullah & IJNDP & Sayed Aya & $n+30$ \\
\hline Dr. & Daud Shah & GAF /PRB & Dr. Kazen & PRB \\
\hline Dr. & Housaini. & ] RC/RPA & Ajmal Shirzay & AR? \\
\hline Dr. & Sanaul Haq Ahmadzai & CRAA & Dr. Bram Schreuder & GINF \\
\hline Dr. & Gerrit Wassink & $D C A$ & S. S. Massood & JCE \\
\hline Dr. & Grililam Saeed & MADERA & Dr. Batiadur & WOA \\
\hline Lr. & Leon Mulken & $D C A$ & Khal i. $1-1.1 \%-R a h m a n$ & $n C B \cap F$ \\
\hline
\end{tabular}

1. Minutes of the linst merting:

a. Itern \#, first paragraph, not Achin but Nangarhar.

b. Item \# 3 , second paragraph, not complete but some.

II - UNDP report about permits:

UNDP asked all agencies to send details of how long it loml. to get permits and detajls of which goods were sent etc. Then, UNDP will take the issue to the Pakistani. Home Secretary for discussion.

DCA said that receivillg a permit for the trangfer of a motorcycle into Afghanistan took 40 days.

III. Review of charging nolicy:

IRC mentioned that they have no problems with bhorging because they began allof their clinics with charging. Shortage of medicine is the main problem ill some areas, 0.9 . in Jaji Mangal but not in Eastern Paktia. The difference- in exchange, rate is also a problem.

MADERA started applying charging policy in its provicus clinics. The clinics in Kunar were established in Decomber 1991 with $50 \%$ charging. MADERA sells its medicine throuch the shops selding human medicino on lihe hisis af $\%$ commission but shopkeepers ask for $5 \%$ rommissim. A specific amount of some important medicines for example. antibiotics, are kept for emergency at the rinic which is given free of charge to the animals.

ARC has been charging and still no problem. ARR said that during the winter months the sale of medicime has doraresed. 


\section{6}

Many agencies will not receive their expected income from medicine because of the fluctuation in the price of the Afghani. At the end of their projects, NGOs can exphain their reasons for the decrease in amount of money caused by exchange rate.

IV. Any other business:

a. DCA had sent samples of: a disease outbreak in kot and Dehbala of Nangarhar Province last July to Holland to be tested. The result showed that 3 out of 5 samples were Rinderpest.

b. Dr. Brown Schreuder, a member of DCA from Holland, is in Peshawar to evaluate the activities of the comittee. He will also work on Serological

examination.

c. Welfare Organization for Afghans (WOA) has started chicken production. NGOs can receive the 6 week ones for Rs. 13-15 each. Supply will start in April. The chicks are vaccinated. WOA can also prepare poultry food for NGOs. The main purpose of this program is to prepare healthy chicks for the UNDP supported poultry projects. Therefore, part of the fund to this project is provided by UNDP which will be re-paid. UNDP has received 20 poultry project proposals 50 far.

WAO will also provide training and consultation in poultry management to the personnel of the NGOs and individuals. They will charge for their services. For more information contact Dr. Bahadur Durani at. WUA phone 45067 . 


\section{7}

$A C B A R$

VETER INARY SUE-COMMITTEE

Minutes of the meeting held on Tuesday April 14, 1992

\section{ANNOUNCEMENT :}

The meeting welcomed: Philippe Leperre, FAO Mazar Sharif, to the meeting.

Previous minutes accepted.

\section{REPQRT ON PERMITS:}

For good to travel cross-border, DCA had submitted a letter to UNDP with details of the problems at present that they haweic faced in getting permits. It appears that it is taking at least 40 days to get permits.

The requests take 2 to 3 days at the office of Commissioner for Afghan refugees. It then goes to either the health department or industrial department which takes weeks rather than days. Then the permit is returned to the commissioner for Afghan refugees taking another 2 to 3 days. Finally it is sent to the Home Secretariat who take 6 days to process it.

UNDP promised that Mr. Muttelingham will discuss the matter with the Home Secretariat.

II. COLD CHAIN:

The meeting understood that Dr. Mehraban was compiling a list of freeze points. It was hoped that this list could be presented at the next meeting.

MADERA was not represented at the meeting, but it was reported that they could share their information at the next sub-committee meeting.

Philippe Leperre mentioned a functional cool room in Mazar Sharif.

There was some discussion. on different types of friges available: Kerosine, gas, gas/electric, solar powered.

ine suggestion was to supply friges to a limited number of strategic sites such as places where there are human clinics with friges (the staff of these clinics would know how to maintain our friges). Samples could be sent to these friges for storage and ice could be made for cold boxes. 


\section{8}

\section{I I " REPORT BY PHL IPPE LEPERRE:}

He explained FAD's project for northern Afghanistan. Project started July 1991.' The aim of the project is to improve animal health conditions in north Afghanistan. The project will rehabilitate government clinics and set up dispensaries. The aim is to work in geographical areas rather than political areas.

FAO will only work where invited by local authorities and where these authorities are willing to support the vaccinators who FAO trains. NO salaries are paid by FAD. Instruments, vaccines and medicines are supplied. The authorities must understand that medicines will be sold and the money returned to FAO in exchange for more medicine. It is up to each district to decide how the vaccinators are renumerated for their work.

FAO's aim is to see the establishment of a self supportive commercial type of system. Three FAO veterinarians train the vaccinators in each district. The intention is to return and give refresher training in the future.

Questions were directed to Philippe about their monitoring about progress so far, about possible conflict with other NGO, projects where salaries are paid. Philippe said that the project is too young yet to be able to comment but will keep in contact.

A suggestion was made that a representative from Mazar-iSharif and one from Quetta attend a meeting in Peshawar may be every second or third month so that there is good coordination between al veterinary projects.

\section{LABORATORY SERVICES:}

Dr. Bahadur Durani was kind enough to come and explain the plans he has for a laboratory in Peshawar. His laboratory will aim to diagnose poultry diseases: Salmonella, Pullorum, Coccidiosis (by autopsy and blood testing), New Castle Disease and parasites.

- Dr. Bahadur is willing to teach autopsy techniques to agencies if requested.

DCA and GAF are also planning to organize simple laboratories to use as teaching facilities for" their training courses and also to prepare samples from the field to be sent to more sophisticated labs. 


\section{9}

\section{A C B A R \\ VETERINARY COOIRDINATIUN}

Minutes of the meeting held on

Tuesday, April 28, 197 ?

\section{Attendants:}

Dr. Neil Chesterton (chairman)

Dr. Sayed Aqa

Dr. Sayed Mohammad

CORIDEV

ARC

Dr. M. Kazem

GAF

PRB

Dr. Gerrit Wassink, Dr. S. Qasein Alemzada

DCA

Dr. Housaini

Dr. Sanaul Haq Anfradzai

I.RC / FRPA

Dr. Mehraban

C.RAA

UNDP

ing. Shahzada Lais

Khalil uraforhman.

L.BI

ACBAR

I. UNDP follow up regarding the permits:

UNDP -Peshawar will contact the permit issuing authorities with permit request. If it fajled to get the positive answer, the issue will be handed over to UNDP - Islamabad.

In the last week of April 1892, the Pakistani government. announced that construction materials and agricultural inputs will be allowed free of any tax to be taken into Afghanistan. But it is expected that it will take time for the government order to take effoct.

I I Information on fridge points and cold rhains:

GAF, IRC and MADERA hasve received funds for the supply of fridges from UNDP. MADERA reported that they have purchasod 5 fridges, 15 ice boxes and 600 ice packs. The recejval of permits and dispatch of them to kunar were done through Afghan Development Authority (ADA). 15 gas cylinders were also purchased for fridges. MnDERA said liat each cylinder is supposed to work for a month. IRC saj.d that their experience show that each cylinder worked for two werks. ACBAR will send a letter to UN]CEF asking information about: the freeze points of other NGOs in different parts of Afghanistan.

III - GAF and DCA information on lraining and refreslier coursers: The second GAF Vet. doctors refresher course will be held in June 1992. The German doctor will come to Peshawar on June 3rd. The course which will be for 10 days which will start the second week of June. Maxinum of no people will be the capacity of the course. Agencies in Quetta will be given up to 5 seats.

The course will be about large animals. List of the proposed subjects by the doctor has already been sent to gal: and it was distributed in the meeting. $n$ copy of the list 
will be sent to other concerned NGOs in Peshawar and Quetta to make their suggestions and comments regarding the contents of the course.

GAF has started a 5 months training course for paravets. 25 paravets are in the course. Another 11 days paravet refrester course will start next week.

DCA is going to start a 3 months advanced paravet course next week. A five months course for paravets was finished just recently. DCA also holds some short -term course (tailor made) on the request of the field staff.

IV. UNDP funding situation:

UNDP said that they have a sum of US\$ 5 Million for OPS for 1992. Out of this amount, US\$ 1.6 Million has been allocated: for veterinary program for $1992 / 93$ at this 5 tage. The on going vet. projects need 2.55 Million US Dollars. The meeting discussed possible ways of adjusting to the

Any other business: UNDP is concerned about the irregularities in the salaries
of field staff. UNDP said that there are some paravets with
good experience which are in good experience which are in charge of clinics but they receive the fixed salary suggested for paravets by the that the issue should be clarifications, it was suggested the subcommittee. 


\section{1!!}

Veterinary training course on epidemiology, diagnosis, prevention and treatment of diseases in cattle, horse/donkey and camel.

Dr. Wolfram Rietschel, Fachtierarzt fur Tropenveterinarmedizin, stuttgart, Germany

1. Introduction

Experiences of 20 month working as a veterinarian with FAO and GTZ in Afghanistan (slide presentation)

2.

Comparative basic information about anatomy and physiology in cattie, horse/donkey and camel

clinical examination under field conditions

Infectlous diseases

5.

5.1 .

5.2 .

5.3

6

6.1 .

6.2 .

6.2 .1 .

.2 .2 ,

J.2.3.

6.2 .4 .

7.

8.

9.

10.

11.

12 :

13.

14.

15.
Viral diseases: Rabies, Pox diseases, Equine Respiratory Disease Complex, Foot- and Mouth Disease, Rinderpest, Bovine Virus Diarrhea, Malignant Catarrhal Fover, IBR, IBV and associated syndromes.

Rickettial and other diseases: Q Fever, Contagious Bo$\checkmark$ ine Pleuropneumonia, Aneplasmosis,

Bacterial diseases: Anthrax; Clostridial Infections, Leptospirosis, Brucellosis, Tuberculosis, Salmonellosis, Pasteurellosis, Glanders, Meliojdosis, Actinobacillosis, Actinomycosis,

Parasitic Diseases

Ectoparagitos

Endoparasites, Diagnosis and Treatment.

Protozoa: Trypanosomiasis, Babesiases, Theileriases

Nematodes (Gastrointestinal, Lungworms, Filariae)

Trematodes (Liver fluke infections)

Taenia (Tapeworm infections, Echinococcus)

Metabolic disorders, use of drugs

Skin and connective tissue, diseases and treatment

Nervous system, Eye and Ear

Digestive system, disorders and treatmen.

Respiratory system, Diseases and treatmer

Reproductive and urinary systems, diseasi.s and treatment

Diseases transmissible from animals to man, precautionary measures to prevent veterinary occupational diseases

surgical work under/field conditions

20 years of veterinary work in domestis and wild animals, comprehensive information about some recent dovelopments in veterinary medicine (S1fde presentation) 
112 


\section{VETERINARY SIIU-COMMITTEE}

\section{Veterinary Special meeting held at IRE Wedriesday 12 May 92 to discuss charging policy}

At previous meetings held to discuss thè same tonic all agencies agreed in principle with the suggestion that medicine should be charged 100 percent.

The purpose of this meeting was to answer two questions:

1. How fo implement $100 \%$ charging for medicines?

2. When to implement $100 \%$ charging for medicine?

DCA thoupht we needed to have opinions on two questions brefore we could answer the above.

a. Is there enough meat and milk in Afghanistan? b. How important are anthelmintic (the main cost of
medicine)?

The meeting answered to the first quostion - "No" and lio 11,e? second question - "Very important." For this reason dCA strossed that any decision made on charging medicine must not affect veterinary services:

GAF commented that farmers (animal owners) most apprerintie the subsidy on medicine. If we charge $100 \%$, they might ask what help the agenesis really giving?

The chairman asked -"If we increase the cost of medicine too quickly to $100 \%$ will the sale "of anthelmintic drop
dramatically?" Three agencies answered "May be". .

Two agencies answered. "Yes".

Two agencies answered "No".

The opinion of the meeting was lhat a suclen increase in charging for anthelmintic could decrease the sales of anthelmintic and so would affect food production.

UNDP commented that as long as anthriminlic are availatil at fors than market price, some will be returned to Pakistan. This will be a loss to Afghamistan and also affect food production. By selling anthelmintic at $100 \%$ they will stay in nfohanistam.

Problems in implementing $100 \%$ charqing:

a. What should be done with remaining medicine when charging rate is increased to $100 \%$.

t.nswers: - Close accounts on an agreed diute.

- Do not inform VFus too far in advance.

- All the old medicine sold at mew rate. 


\section{4}

b. How do agencies finance initial 6 months supply of medicines? DCA estimated that they would need to find
Rs.170,000 for each VFU. monfth salary and running cost line item.

- Shopkeepers in districts close to Peshawar could be given :or sold an initial kjt which would be replaced after being sold. If the veterinarian or shopkeeper replenished the kit from the NGO, transportation cost would be paid. This initial kit will act as a revolving fund and so reduce. the initial amount of money spent on medicine.

DCA suggested using a vehicle to regularly visit all field units to monitor and
replenish the medicine.

c. Who will be responsible for losses? (For example, if
paravet does not come back.) paravet does not come back.)
rs: - UNDP gives a line item to cover a $20 \% 1055$. Answers: - UNDP gives a line item to cover a $20 \% 1055$.
- UNDP gives a $20 \%$ kit to be used as a
revolving fund.

d. Safety of money that will need to be returned from clinics a long way from Peshawar.

Some final comments:

DCA: "We must first support our own staff rather than give
profit to shopkeepers." DCA: "Vet staff will not work as well if they are not making
money from medicine." UNDP: "Vet. staff must not be so busy selling inedfine that other activities suffered."

//1: "A number of shopkeepers will create compqtition and
reduce over charging." The secand question "When to implement $100 \% "$ was left for another
meeting.

Attendants:

Dr. Neil

Dr. Wassink

COMDEV

Dr. S. Ahmadzai

$D C A$

Dr. 5. Aqa

CRAA

Dr. Houssaini

ARC

IRC

Dr. Halimi

Dr. Sayed Mohd

Dr. Mehraban

Dr. Daud Shah

Khalil ur Rahman

DCA

GAF

UNDP

PRB

ACBAR 


\section{5}

\section{$A C B A R$ \\ VETERINARY SUH-COMMITTEE}

Minutes of the meeting held

on Tuesday, May 12, 1992

\section{Attendants:}

Dr. Neil Chesterton (chairman)

Dr. M. Houssaini

Dr. Gerrit Wassink

Dr. Mehtaban

Arch. Hasib Latify, Arch. Almad

Dr. Sayed Mohammad

COMDEV

IRC /RPA

DCn

UNDP.

GTZ

GAF

FAD

ARC

PRB/GAF

ACBAR

I. Discussion on 100\% charge on medicine:

The issue was discussed and everyone agreed that medicine should be charged $100 \%$. The main things were how and when to apply it.

UNDP in its inter-agency meeting has proposed that this policy has to be applied even before Janaury 1983. The vely important and costly medicines are anthelmintics. Some NGOs questioned if farmers are able or will be willing to pay for anthelminitcs at full cost. UNDP said that most of the farmers know the importance of anthelminitcs and they should be left free as to whether lhey want to buy antilelmintics for full cost or not. UNDP believes that those who know the importance of these medicineis will buy them for full cost.

It was decided that: the issue should be "discussed in a sepcial meeting which will be held on Wednesday, May $13-7$ ? The meeting will be held at IRC.

\section{Suggestions on GAF refresher course:}

List of the subjects selerted by the German lecturar of this course was distributed with the minutes of the last meeting and concerned NGOs were asked to comment on the contents of the list. The mepting agreed that all of the disenses which are not common in the region, erpecailly in nfghanistan, should be excluded from the list of the contents of the course. FAO kabul commented that not enough technical data is available to spcify which diseases are present and which are not. The laboratory services available in Afghanistan are not able to carry out this task.

It was mentioned that close contart should be kept with fno Kabul. FAO Kabul has a large plan to establish a vetorimary 
net work in Northern Afghanistan.

III. GAF report on the recent visit from Nangarhar Province:-

GAF mission visited Nangarhar Province on the 10 May 92. GAF wanted to talk with the authorities in Nangarhar regarding the veterinary activities but the key persons; governor and the security in charge of the province were not in Nangarhar. GAF met the over all in charge of the veterinary programs of the previous government in Nangarhar Province. It was observed that there was a lot of modern veterinary equipment and facilities in Jalalabad. There was some staff too. The staff were not paid their salaries and they did not feel responsible to any source. GAF expressed its concern that if immediate measures are not taken by the Peshawar based agencies, most of the equipment and facilities will be lost. It was also said that right people were not in the right places.

The matter will be further discussed in the next subcommittee meeting.

IV. GTZ and construction of animal clinics:

The matter of construction of some animal clinics of the NGOs to be built by GTZ on the contract base was discussed in two sub-committee meetings earlier this year.

GTZ prepared the details of the structures of the clinics and said that a model clinic containing 3 rooms, a basement and a bathroom with the stone foundation, must clay walls and domed roof will cost minimum of Rs.180,000. Of this total cost Rs:40,000 was the GTZ technical staff costs. The remaining Rs.140,000 could be reduced depending on the amount of donated local labor. UNDP representative said that the approval of the high cost of the construction of the clinics should be discussed at the higher UNDP level. Some NGOs proposed that ARCON could be contacted as donors for the construction cost of the clinics and UNDP will be continuing to provide the running cost of those clinics. GTZ suggested that NGOs should contact the above mentioned donor and then after receiving of funds contact this agency to start the construction. 


\section{$A C B \wedge R$

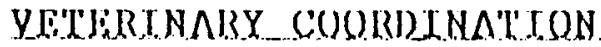

Minutues of the last mreting held

on l'uesiay, . May 23, 1.992

\section{Anuoucemenlis:}

A. DCA has prepared a rubliration murler life lame of

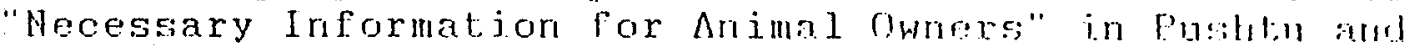
Dari. The publication conld be rocejved Rra. 14 a cory from DCA.

B: Pushtu version of E.VWes mamal is realy lov distribulion at DCA. NGOs were asked to indicate their neede;.

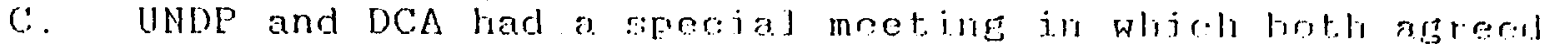
on $80 \%$ charge on medicine. UNDP will be providing medicine for $70 \%$ to veterinarjans and paravels and thry

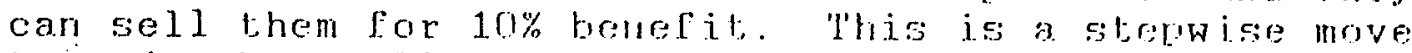
towards the policy of $100 \%$ charge on medicine. Some new pojnts which were discusesed and acreed on aro:

a. castiabion - bis animals $\Lambda P s .100$

- small. anima].s At: 50

b. wound dressing A[\%.50

Materials used for dressing will he free. The counsultation fee will remain the same agrefer ron in life previous; meetings.

II. Update on GAF refresher coursic:

GAF will start registration for the second training proriram on June 15. $A$ letter wil. be sent to MCJ rogingling bhe change of the date.

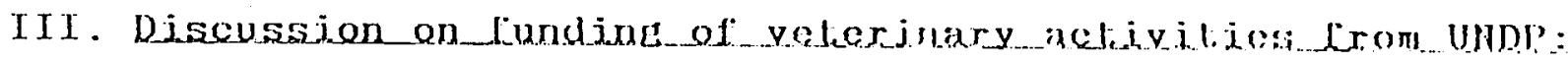

Seniar JHDP manager was: in Peshawar. He arinouroed that alter December 31st 199\%, all velerimary and aErjolldural actjuities will not be funder from UHDP,OPS lesihawar.

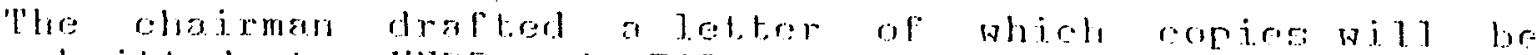
submitted to JNDP and FAO auLhorities ju lesianabad aril Kabul. The main let.es: will re sent bo tile Greneral. directors of the two UN agericies to Neb York and Pone. [n this letter concern will be expressed over the rature of NGOs veterinary programs. Anthony Fitzlierbert and Bot. Eaton will be requested to attend a meeting wjuh NGor involved in veterinary activities. The main thing to be discussed is the sustainability of veterinary progrgms funded by UNDP/OPS. 
UHDP said that a UH mission is going to come to Pakistan in approximately 2 months to evaluate the issue of hand oyer to FAO. The Veterinary Sub-committee asked if the mission could come earlier than two months because by the time thr. mission prepares o. report it will be close to the time funding will stop. It was hoped that ACBAR Vet. Subcomittee could heet this un mission. 


\section{$\triangle C B \cap B$ \\ YEUERINARY SUB-COHMIITIER}

Minutes of the meetine hetd on luesday, June 23

Attendants:

Dr. Neil Chesterton (chairman)

Dr. Gerrit Wassink

Dr. Mehtaban

Dr. Daud Shah

Dr. Sanaul Haq Ahmadzai

Dr. Sayed Mohammad

Dr. Sayed Aga.

Kahlil ur Rahman

COMIDEV
DCA
UHIDP
PRB
CRA
GAF
$\triangle R C$
ACRAR

I. Mindies of the Jisit medijing:

Minutes of the last meeting were apuroven.

IT - Anuouncomenles:

In one of the previons meetings llNDl/OPS annourced that they Will have only US $\$ 1: 6 \mathrm{mijl}$ jor for 1992 out of which only

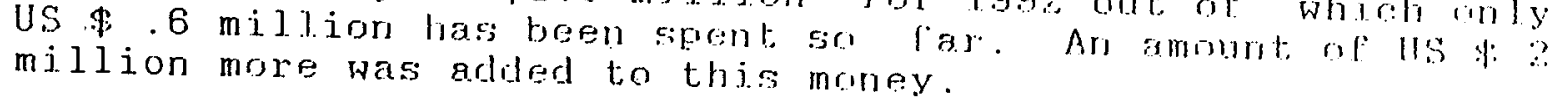

II. Reports abont the Goyernment clinics in Nangarhar:

The government veterinary olinio in Jalalabal has atoul so personnel. None of the Noos has started to takro conterol rif the clinic and the staff. INDP anmoumed that it will mol some anthelmintics talie over of Government olinice. finly

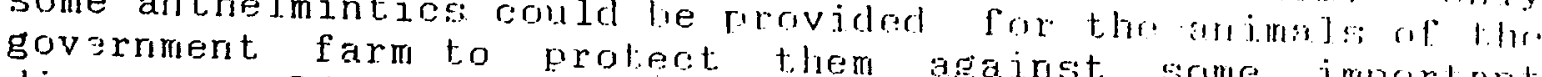
diseases. DCA wanted to open a them against some jmprombt

III. G GP yinit of Kubu]:

The director of GAF visjiterl kabul and talked to somm lln people there. He was promiser lhat INDE will combimo

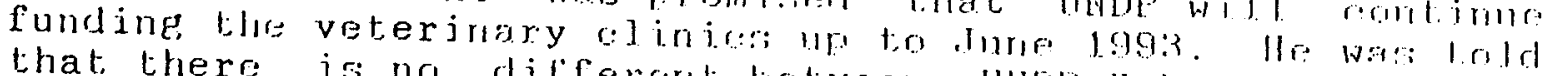
that there is no different botween lHWP Kalmo, Masor aur Harat. Only a working lire has been reown up leteweren the

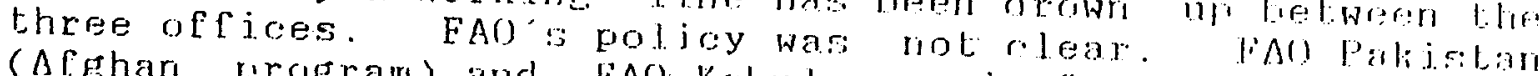

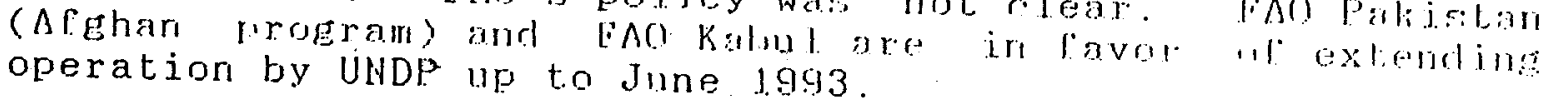

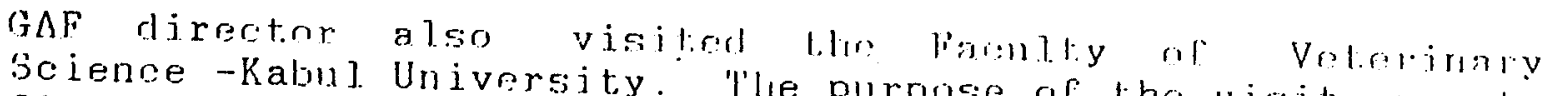
find out the cooperation. 'lle purpose of the visit was to training veterinary field of the Eaculty acodomic staff in The Faculty expressed their coop with HGOs in Afehanistan. director said that the paropestion in this regard. GAF received damages and was arol.ty clinie in Darul Mmar hal

IV. Any ofiher hurinesis: 
IV. Any ather business:

\section{0}

a. DCA reported that a member of their board wil. meet. with Dutch Government regarding funding. The Dut:ch Government pays this money from emergency fund. $\Lambda$ member of this board will also go to Rome to talk to FAO authorities in thiss regard.

b. Mr. Chairman met with Bob Eaton and discussed the jsesur: of the continuation of UNDP fund. He was told that. there is no guarantee of fund after December 1992. Ho talked to Anthony Fitaherbert too. Anthrny disl rol. know anything about it. C. Some discussion wass held on the amendment of the
proposals to UNDP. 


\section{$A C B A R$ \\ VETERINARY SUB-COHMITTEE}

Minutes of the neeting held on ruesday, July 7, 1992

\section{Attendants:}

Dr. Neil Chesterton (chairman)

COMDEV

Dr. Sayed Aga

Dr. Mehraban, Dr. J. D. Woodford

ARC

Dr. Mohibullah Halimi, Dr. S. Qasem Alemzada

UNDP

Dr. Sayed Mohammad

DCA

Dr. M. Kazem

GAF

Pr. Sanaul Haq Ahmadzai

PRB

Khalil ur Rahman, Marie Mingo

CRAA

ACBAR

\section{Minutes of the last neeting:}

Minutes of the last meeting were approved.

\section{Announcements:}

It was announced that SCF-US and ARR Quetta each need a veterinarian.

III. What plans do agencies have to move into Afghanistan:

So far most of the agencies have not decided to move their main offices to Kabul. This is because of the lack of security in that city. Centers of some of the provinces are safe and some agencies have started to open sub-office(s) in some of the provinces where they work or intend to work. GAF is going to open an office in Harat and CRAA is going to open an office in Jalalabad. GAF has opened a store in Kabul next to the $\Lambda$ fghanistan Bank. 'This" store could be used temporarily by staff of other NGOs who travel to Kabul.

It was said that if NGOs can have a shared office, this will decrease the cost.

For the legal operation and opening of main or sub-office in Kabul by the NGOs, the protocol should be signed between the agency and the Ministry of Foreign Affairs of Kabul. The coordination requested that the copies of the protocol which should be signed by NGOs with the Kabul government should be distributed to the coordination members.

IV. Personnel needs of NGOs for future:

It was said that at present the Kabul government is not in position to employ the veterinarians worked with the previous government. Since most of them have been living in the rural areass, they could be hired by the $\mathrm{NGOs}$. It wass 
said that NGOs can cooperate in this regard in-between.

UNDP -Quetta said that they do not support employment of veterinarians for South-Western Afghanistan. Training of BVWs should be enhanced to cover the need. UNDP -quetta added that no more paravets should be trained. A great number of them already exist the country. The competition between the paravets and the BVWs should be reduced. Some coordination members said that there is lack of paravets in Harat, Badghis, Ghor, Balkh and some other central and North-Hestern provinces. UNDP -Quetta said that their system is not in favor of paying salaries, therefore, the independence policies should be encouraged. Some members said that the technical knowledge of BVWs may not be high enough to answer the needs in this area of work.

UNDP/OPS -Peshawar was told that no proposals of newly established NGOs should be received for funding because until the new projects are getting experienced, the project will stop. It was also said that as soon as the Kabul government goes toward normality, UNDP/OPS will no exist anymore.

Checking the abilities of the Veterinarians employed by NGOs:

There are different ways to check the technical knowledge of the veterinarians who are going to be employed by NGOs. The most important steps in this screening process are:

a. Verification by any professor from the Faculty of
Veterinary Science.

b. Academic discussion before the employment.

c. Practical examination of the vet. to be employed.

Any other business:

a. UNDP/OPS is organizing a workshop entitled "The efficient use of anthelmintics in Afghanistan". This workshop has been organized in order to bring together Veterinarians and Agricultural coordinators of NGOs in Afghanistan with some of the more important manufacturers and importers of anthelmintics in Pakistan to promote the more efficient use of anthelminitcs in Afghanistan. The workshop will be from 3rd - 5 th August 1992, and is sponsored by CibaGeigy (Pakistan) Ltd., ICI (Pakistan) Ltd. and Smithkline Beecham (Pakistan) Ltd. It will be held at Pearl Continental Hotel - Peshawar. The invitation cards along with the timetable were sent to the concerned agencies. In the attached form with the invitation card, the $\mathrm{NGOs}$ have been requested to 


\section{3}

indicate whether they want to attend the whole workshop or to the Luncheon on the first day.

The opening day of the workshop could be attended by the Agricultural coordinator's of HGOs or someone with only. a secondary interest in Livestock Health up to Luncheon.

b. UNDP/OPS -Quetta signed the contract of 15 veterinary programs with BBC. These programs will include some dialogues and scientific topics. Some programs will deal with repatriation. NGOs were asked to give their ideas in this regard. 
124 


\section{5}

\section{$A C B A R$ \\ VETERINARY COORDINATION}

Minutes of the meeting held on Tuesday, July 21. 1992

\section{The attendants:}

Dr. Neil Chesterton (chairman)

COMDEV

Dr. Sayed Mohammad

GAF

Dr. Gerrit Wassink, Dr. Halimi

Dr. Sanaul Haq Ahmadzai, Dr. Shafiq

DCA

Dr. Housaini

Dr. Mehraban

CRAA

Khalil ur Rahman

I RC/RPA

UNDP

ACBAR

I. Minutes of the last meeting:

innes

The following should be added to the item \#V of the last meeting.

c. Attitude of the vets toward the farmers.

\section{Announcements:}

DCA had sent a sample to Holland to be tested for Mycoplasma. The result was received which did not show Mycoplasma. The sample was taken from Nangarhar.

b. IRC announced 3 vacancies for veterinarians.

III. The protocol which should be signed between the Kabul government and the NGQs:

A draft of the protocol was received by Dr. Neil. The protocol were read at the meeting. The Kabul Coordination of ACBAR has sent a mission to Kabul. One of the aims of the mission is to bring the final draft of the protocol. The developments in this regard will be reported to the next meeting.

IV. Developments on UNDP kerkshop:

Along with the invitation cards, UNDP had requested the NGOs to indicate their porticipation in the workshop of $3 \mathrm{rd}$ August. Only a few NGOs have replied the request. Once again, the NGOs were asked to inform UNDP about their participation.

V. UNDP-BBC programs:

In the previous meeting, NGOs were asked to send their comments on the UNDP proposed programs for BBC. The meeting discussed the issue and suggested that the program should emphasize diseases. 
VI. Any other business:

a. CRAA reported the observation of Hemorrhagic Septicemia in As-ad Abad, Kunar. The disease was identified based on the clinical symptoms; swelling around the neck, high temperature and hard breathing. The animal was treated Teramycine but was not effective. The rest of the animals were vaccinated. The agency sent some vaccine there last year too.

b. DCA field staff vaccinated animals for Black Quarter in Parwan. The animals recovered after 24 hours. The vaccine was received from Lahore last April. CRAA used the same vaccine (from Lahore) about 4 months ago. Fifteen animals died.

I C.C reported the outbreak of B. Q. in Khost. The coordination suggested that IRC should contact GAF and DAC to get vaccine and other assistance.

c. CRAA observed FMD in Hada and Jalalabad surrounding areas.

d. DCA claimed that GAF field staff is still selling medicine for $30 \%$ which.creates problems for other'NGOs. GAF said that since the policy is in rapid change, they could not adjust. The new $80 \%$ policy will be announced soon.

e. UNDP/OPS have ordered 1.5 million dozes of vaccine for New Castle Disease from Australia. It may arrive in a couple of months. According to UNDP, the vaccine production centers in Pakistan may not be able to provide vaccine for the remaining 10 months program. It will be better to order vaccine outside Pakistan. Some agencies said that VRI-Peshawar agreed to produce vaccine.

Sometimes unqualified professional staff create problems for the NGOs. When they are dismissed by one NGO, they go to another one and cause a waste of time. The Sub-committee suggested that NGOs should reveal the names of such people so that other NGOs will not be fooled by them. DCA gave the name of the following people who were dismissed being unable to perform their duties:

- Abdul Sami

- Abdul Wadood

- Shamsur Rahman
Vet. assistant

Vet. assistant paravet 


\section{7 \\ A C B A R \\ YETERINARY SUB-COMMITTEE \\ Minutes of meeting held on Tuesday. August 11,1992}

\section{The attendants:}

$\begin{array}{ll}\text { Dr. M. Halimi (vice chalrman), Dr. Wassink } & \text { DCA } \\ \text { Dr. Ghulam Saeed } & \text { MADERA } \\ \text { Dr. Mehraban } & \text { UNDP } \\ \text { Dr. S. S. Masood } & \text { JCE } \\ \text { Eng. Bilal Ahmad } & \text { ARCON } \\ \text { Dr. Mohd Nabi Housalni } & \text { IRC } \\ \text { Dr. Blsmellah : } & \text { PRB } \\ \text { Dr. Sanaul Haq Ahmadzal } & \text { CRAA } \\ \text { Dr. Sayed Mohammad } & \text { GAF } \\ \text { Shaflq, Khalil ur Rahman } & \text { ACBAR }\end{array}$

I. Minutes of the previous meeting:

a. Page 2, 1tem 5-b was corrected that "the animals treatment." were vaccinated for Black Quarter showed alergic reaction and recovered after 24 hours without

b Page 1, Item 2 was corrected that after the result from Holland was negative for Mycoplasma, no vaccination was done for CCPP.

II. Announcements:

No announcements.

III. Discussion over the protocol which should be slaned between the NGOs and the Kabul Government:

The copy of protocol brought from Kabul was distributed to the attendants of the meeting.

In the ACBAR General Assembly of August 6, it was questioned if any of the NGOs have signed the protocol. None of them replied with; yes. The Sub-committee requested ACBAR to ask the Afghan Consulate in Peshawar if it is in position to sign the protocol with the NGOs
in Peshawar.

- IV. Report on UNDP workshop held in Peshavar:

Most of the attendants of the vet. Sub-committee attended the UNDP workshop. The lectures and the discussions were found very possitive and useful. They said that the speakers discussed the important points. It was said that the topics discussed by the representatives of the 


\section{8}

workshop hosting companies were very simple and primative.

It was suggested that an appreciation letter should be sent to UNDP through the sub-committee -ACBAR and UNDP should be encouraged to hold some more workshops of this type.

Dr. Housaini of IRC was assigned to prepare a draft on the workshop of 3rd August and include comments for the improvement of the future ones.

Through the discussions, Valbazin, Nilzan and Fasinex were found the important Anthelmentics. Shanazol is cheap and could be tested by some NGOs. But it was also mentioned that the cheap price is not a good indication of a product.

IRC is planning to hold some district-level seminars for the animal owners of the area where they have programs. The important Anthelmentics will be introduced to them and then their views and experiences will be taken in regard. It was mentioned that chosing any new Anthelmentic to the area should be done in consultation with UNDP.

y. The next GAF refresher course:

The third GAF refresher course hopefully will be started on september 20, 1992. Dr. Kumper will be the guest lecturar to the course. The schedule of the course prepared by Dr. Kumper has already been sent to GAF. Copies of the schedule were distributed in the meeting. Some comments were made on the withdrawal of some of the unnecessary topics which are not applicable and practicable in this course or higher than the knowledge of some Afghan veterinarians. The period of the course is also a limiting factor for the cut down of some of the topics.

It was suggested that the veterinarians who could not attend the first two courses should be introduced to this one. The fourth course of this series will probably be held in Kabul so that the vets of the Northern provinces
can attend it.

YI. Any other business:

Since NGOs are expanding their programs and some new veterlnarians, coming from Kabul, are applying for Jobs, UNDP proposed that a committee should be set-up to verify will complete the first int new employment. The applicant NGO will refer him/her by technical evaluation. 
The following people were sald to be the members of the committee :

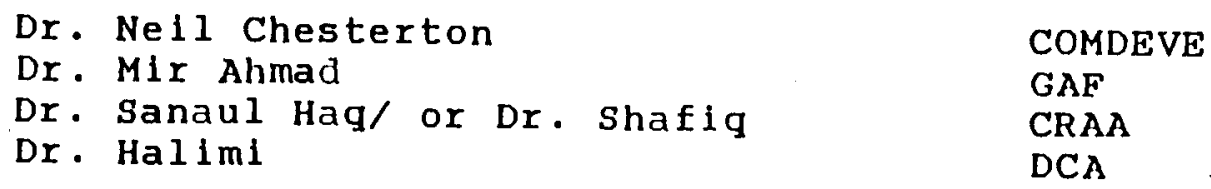

The committee will have regular sittings each Thursday at 10:00 am at the GAF clinic.

The Veterinary Sub-committee agreed that nobody could be hired without the certification of the committee. This agreement is effected from August 11, 1992 . 
130 
ACBAR

\section{VEITERINARY SUB-COMMIITEE}

Minutes_of the meeting held on_Iuesday, Aususit_25, 1992

The participants:

Dr. M. Halimi (vice chairman)

Dr. Mehraban

Dr. Daoud Shah

Dr. Say.ed Mohammad

Dr. Sayed Qasem Alemzada

Dr. Mohammad Nabi Housaini

Dr. Sayed Aga

Dr. Ghulam Saeed

$\because$ Dr.: Bismellah

Dr. Bashir Ahmad

Dr. Sanaul Haq Ahmadzai

Dr. Shafique

Shafig Ahamd

DCA
UNDE
PRB/GAF
GAE
DCA
IRC/RPA
ARC
MADERA
PRB
CRAA
CRAA
CRAA
ACBAR

I. Minutes of the last meeting:

Minutes of the last meeting were aprraved.

II. Announcements:

The outbreak of ANTHRAX disease in Bar Roghani village, Rodat district was announced by DCA. It was stated that 16 cows and a lot of sheep were died as a result of this should immediately decided that a team along with vaccine

The recent report of PRB from the field shows the outbreak of AlsthRA disease in Baghlan-i-Sanati and Dahani Ghori. The people were complaining as there was no vaccine in the area. The report also discloses the problem of the people in Badakhshan province regarding vacciration.

It was announced that there are a lot of difficulties. in purchasing vaccine from Pakistan. It was suggested that the vaccine should, in any case, be bought, but the best way should "be found for purchasing. All participants agreed that major agencies should include the reguired amount of then have toccines in their purchase order. 'The sinall. HGOs send a letter to UNDP Islamabad to cont Peshawar promised t. Pakistan regarding the purchasing problems the government of

As. ANTHRAX and EHTEROTOXEMIA vaccines are much effective, it was suggested that they should be ordered from Australia. UNDP promised to provide one million doses of each ANTHRAX
and INROTAXEHMIA vaccines. 


\section{2}

III. How BYHs should be controlled:

The vice chairman suggested how to find a proper way to control BVWs. The main complain of the people is that doctors and paravets do not give them medicine. As Llie bVW; have to pay in advance for receiving the medicine, they cannot take much medicine from their clinics because in case they do not sell the medicine, they will sustain the losses. Surveys show that $80 \%$ of BVWs are running out of medicine. It was clarified that the problem can be solved by training competent BVWs. UNDP suggested that $40 \%$ of medicine should
be given to BVWs.

UNDP's monitoring team was criticized as they have not monitored the BVWs as much as reguired. It was suggested that a day monitoring is not enough for a clinic. The time of monitoring should be extended and the people should be contacted regarding the work of BVWs in the far from villages.

IV. MADERA about the acceptance of $80 \%$ charging policy:

The representative of MADERA clarified that there was a MADERA. It was known that they new charging policy at the new policy yet. The participants not decided to apply committee decided that MADERA ACBAR to accept the phould be requested through problems.

V. Any other business:

Minutes of the"Veterinary Technical Evaluation |Committee" were distributed to the participants for discussfon. It was whether the applicants had completed out through their staff or not. It was questioned their higher education veterinarians should be introduced to the compit well-known technical interview. The participants comittee for only categories should be introducedicipants decided that all Since the NGOs

there is a need for 40 veterinarian veterinary activities, be decided that for 40 veterinarians. Therefore, it should the government of veterinarians, who guit their jobs with NGOs or not. Af ghanistan, should be employed by the veterinarians; who All participants agreed that senior inside Afghanistan and for job, should be asked for work from the local authorities so a none objection certificate conflicts the employees themselves and case of arising any will be held responsible. For and the local authorities organization the applicants should purpose of what other was decided that a special meetinging the NOC from, it Thursday, August 27 at 9:00 meeting should be held on employment or unemployment am at IRC/RPA to discuss the recently come to Pakistan. of the veterinarians, who have 


\section{VETERINARY் SUB-COMMITTEE \\ Minutes of the special meeting on Employment held on Wed:, sept. 2, 1992}

The attendants:

Dr. Halimi (vice chairman), Dr. Samsore, Dr. Alemzada DCA

Dr. Sayed Mohammad, Dr. Daud Shah

Dr. Mehraban

Dr. Housaini

GAF

Dr. Sayed Aqa

UNDE

Saf 1

Dr. Bismellah

I RC

$\triangle R C$

Khalli ur Rahman

CRA入

PRB

$\triangle C B \Lambda R$

\section{Employment of the new personnel:}

This special meeting wàs called to discuss:

a. Whether to employ new arrivals or not.

b. What conditions they should be employed under?

c. Free of any future responsibilities.

nfter an hour discussion the members agreed on the following
points:

1. Mll well-known members of the previous regime and those who committed crimes against the nation should not be accepted for any job within the veterinary programs.

2. Those who changed their profession for any other governmental activities should not be given the job
within the veterinary programs.

3. The present employees of the Afghan government higher than the $3 r d$ rank should not be hired in order to support the present government. The technical committee can decide in exceptional cases.

4. Professors of the Universities could be hired based on special contracts until the University re-opens.

5. Allof the new employees have to be ready to work in
field.

6. All new employees should present the agreement of the local authorities where they are assigned to work.

7. The employment of all new employees should be approved Erom the technical point of view by the Technical
Committee set-up for this purpose.

Considering the above stated items the agencies can employ new arrivals. Those who meet the employment criteria will recelve the same benefits of the normal employees. 
134 


\section{$\triangle C B A R$ \\ Minutes of the meeting held on Tuesday. Sept. 8,1992}

\section{The attendants:}

$\begin{array}{ll}\text { Dr. Neil Chesterton (chairman) } & \\ \text { Dr. G. Wassink, Dr. S. Q. Alemzada } & \text { COMDEV } \\ \text { Dr. Sayed Mohammad, Dr. Daud Shah } & \text { DCA } \\ \text { Dr. Bismellah } & \text { GAF } \\ \text { Dr. Housaini } & \text { RPB } \\ \text { Dr. Sayed Aqa } & \text { IRC/RPA } \\ \text { Dr. S. Haq Ahmadzai, Dr. Bashir, Dr. Shafiq CRAA } \\ \text { Dr. Ghulam Saeed } & \text { IRC } \\ \text { Khalil ur:Rahman } & \\ \end{array}$

I. Minutes of the previous meeting:

Minutes of the previous meeting were approved.

II. GAF Refresher Course:

The course will start on Monday, september 21. Invitations for the agencies were distributed in the meeting. Agencies GAF.

III. Disease Report by CRAA:

In one of the previous meetings it was indicated that the signs of outbreak of Anthrax in small animals and Blackleg Khel, Canal 27 and Roghany vi in various villages of Ghani these areas are serviced village of Rodat district. Since investigate the problem. ' by CRAA, it was requested to

A team of four veterinarians including the director of CRAA and the representative of UNDP went to Nangarhar Province on August 27, 1992. They stayed in the area for 3 days. After disease were found the suspected areas no signs of the two from a sheep and there. However, three blood samples; were sent to VRI-Peshawar The samples distributed in the meeting. The result of the lab tests were

Transportation and lab samples were prepared by CRAA.

IV. NGOs with projects from different donors: It was agreed that the topic should be discussed in the next
meeting of the veterinary sub-committee.

MADERA about the acceptance of new charging policy: MADERA will keep the 508 charging policy up to the
1992. 


\section{6}

VI. Discussion over the new charging policy considering the

Some of the NGOs said that the discussion over the increase In medicine charge from $50 \%$ to $80 \%$ was held at the time when the UNDP was in shortfall of budget and also the situation in Afghanistan was lmproving. But with the latest developments, it seems that it will take a long time for the economy of the Afghan community to return to its pre-war conditions or even to the conditions of early 1992 . Fluctuation in exchange rate is very high. In addition UNDP is in a better funding position. Therefore, it is advisable to discuss the issue of "not raising medicine charge under the present conditions" with UNDP. UNDP/OPS was requested to report the result to the next meeting.

NGOs asked the questions "Are we doing the correct thing for Afghanistan to raise prices when the economic situation is deteriorating?" "What does the UN think about vet. clinics increasing charges when UN is also funding relief distribution in some of the same districts?"

The agenda for the next meeting which will be held

at $8: 30$, Tuesday September 22

I. Minutes of the previous meeting.

II. Announcements. III. UNDP reply to the request of the sub-committee members about
charging policy.

IV. NGOs with projects from different donors.

V. Any other business. 


\section{7}

\section{$\triangle C B \triangle B$ \\ VETERIMARY SUB-COMMITTEE}

Minutes of the meeting held on Tuesday. September 22, 1992

\section{The participants:}

$\begin{array}{ll}\text { Dr. Neil Chesterton (chairman) } & \text { COMDEV } \\ \text { Dr. Sayed Aqa } & \text { ARC } \\ \text { Dr. M. Halimi } & \text { DCA } \\ \text { Dr. Gerrjt Wassink } & \text { DCA } \\ \text { Dr. Daoud Shah } & \text { GAF } \\ \text { Mr. M. Kazem } & \text { PRB } \\ \text { Dr. Sayed Mohammad } & \text { GAF } \\ \text { Mr. Tim, Leyland } & \text { UNDP } \\ \text { Dr. Q. Qusem Alemzada } & \text { DCA } \\ \text { Dr. Mehraban } & \text { UNDP } \\ \text { Dr. Housaini } & \text { IRC/RPA } \\ \text { Dr. S. Haq Ahmadzai } & \text { CRAA } \\ \text { Shafiq Ahmad } & \text { ACBAR }\end{array}$

I. Minutes of the orevious meeting:

The minutes of the previous meeting were approved.

II. Announcements:

Ho announcement.

III. UNDP reply to the request of the sub-committee members about charging policy:

The chairman reported on his meeting with the UN regarding the charging policy. He was assured by the UN that if serious discussion is needed, then the UN would attend these discussions. The UNDP sees veterinary program as a long term program that must not be affected by short term periods of relief need.

The UHDP also pointed out that we are asking farmers to contribute only to the cost of medicine. Medicine is only a part of the large total UNDP contribution to each veterinary field unit.

Agencies were asked to comment on UHDP remarks:

IRC/RPA said that there are a lot of animals in Yaqoobi and Alishir districts. The people of these areas ask for medicine, but we cannot provide them medirine. The same problem was mentioned in Mosa Khil district. IRC/RPA ras of the opinion that there should be $80 \%$ charge on the medicine.

ARC disclosed that the people of Logar provinee were not ready to accept $30 \%$ charge on the medicine. Furthermore, ARC stated that the people of Malistan and Jaghori accept $50 \%$ charge on the medicine not $30 \%$. ARC agreed for $50 \%$ charge, and stated that $30 \%$ charge will create problem for 
them. The expiry of medicine was mentioned as an example of the problem.

UNDP mentioned that if the advantages of medicine are explained to the farmers carefully then they will be ready to buy the medicine. The positive result of the explanation in Zabul province was mentioned as an example.

Regarding the increase of charges it was stated that it was not because of funding problem. It was claimed that the medicine appearing in the market was the biggest problem. Unless the price of medicine was increased there would never be self supporting elinios in Afghanistan.

The chairman suggested that whether the participants agreed with $80 \%$ charging folicy or not. Except ARC, 311 other participants agreed with $30 \%$ charge on the medicine. ARC and GAF wanted to bring the issue into discussion for decreasing the charge to $50 \%$. The chairman suggested that if agencies have serious things, they can bring it to the next meeting.

IY. WGOs with projecte from different donors:

DCA and PRB had problem of overlapping of their projects in Jabul Saraj distriot. The chairman suggested that these two agencies should sit together and solve their problem themselves and report the result to the next meeting. UNDP asked the agencies that in case of establishing any clinics they should send the list of their new clinics to UNDP to prevent duplication of the projects. All agencies were asked to bring up to date list of present ongoing and proposal clinics to the next meeting.

PRB announced that ARCOH is going to open some clinics and that would create problems for other HGOs. UNDP suggested that ACBAR policy along with database of UNDP should:be sent to ARCON to prevent further problems.

V. Any other business:

UNDP announced that they have $1.5^{\circ} \mathrm{million}$ doses of N.D.Y. vaccine in the store and asked the NGOs to let UHDP know their requirement. Horeover, they are trying to get AlTHRAX and ENTEROTOXEMTA vacines.

Technical Training Eommittee:

DCA arid that the linowlerige of new reterinarians are vety low and they ask for study materialo. Uilde atated if they aeed fund for orinting the materials then WNDP will assist them. It vas agreed that naterials would be given to the veterinarians. It is the responsibility of the asency introducing the veterinarians to provide ary training eto. necessary. DCA requested a minimum of one week notice when introducing a veterinarian for the examination. 


\section{9}

$\underline{\mathbf{A}} \mathbf{C} \mathbf{B} \mathbf{R}$

VETBR I NARY BUB-COMMITTRB

Minutes of the meeting held on Tuesday, oct. 6,1992

I. Minutes of the previous meeting:

Minutes of the previous meeting were approved.

II. Announcements:

A. DCA and UNDP have prepaxed guidelines for the use of: NDViHR which were distributed in the meeting. The DCA was in English and the UNDP was in Pushtu.

B: The vaccancy of a veterinarin at MCI -Quetta was announced at the meeting. It was suggested that the MCI letter should be sent along with the minutes of this meeting.

III. Dlscussion over the overlap of DCA and PRB programs:

There was a problem over the set-up of the veterlnary clinics between DCA and PRB. PRB has its clinic in Jabal-usaraf and DCA in Matak. DCA said that the areas where PRB clinic operates is part of the activity of DCA's clinic. But PRB claimed that Matak is part of galang and the two are different districts. PRB also claimed that GAF's clinic of Panjshir has been operating in PRB 'areas. The chairman suggested that the issue should be discussed between the two agencies and with GAF and the result should be reported to the next meeting.

IV. Discussion over the employment issue:

It was suggested that the pollcy formulated regarding the employment of new arrival at the special meeting of september 2, 1992 could be re-phrased and could be accepted as suggestions, not policy.

v. UNDP about the provision of vaccines:

UNDP representative talked with the Livestock secretary at Is lamabad. The secretary said that there is no problem for the NGOs to receive vaccines from Pakistani sources.

GAF suggested that it would help if UNDP can import vaccine from Australia. NGOs will then get the vaccine from UNDP. DCA has no problems getting vaccine. At present from VRI's in Pakistan if they plan far enough ahead with their ordering. 


\section{0}

vI Any other business:

A. Dr. Nell announced that ComDEv is having difficulty finding a replacement for his position. He plans to leave early 1993. After consultation with UNDP it is hoped that another agency can be found to continue the UNDP funded clinics.

B. UNDP is planning to hold courses in Clinical Diagnosis of Pregnancy. The course will be taught by one of the experts, a former professor of Kabul University. The professor will be invited to participate in the next Veterinary sub-committee meeting.

The attendants:

Dr. Ne11 Chesterton (chalrman)

Dr. Halimi (vice chair), Dr. Hassink, Dr.Alemzada

COMDEV

Dr. Sayed Aqa

Dr. Mehraban

Dr. Sanaul Haq Ahmadzal.

Eng. M. Kabir

Dr. Housain 1

Khal11 ur Rahman

DCA

$\triangle R C$

UNDP

CRAA

PRB

IRC/RPA

ACBAR

The agenda for the next meeting which will be held on Tuesday:
oct. 20,1992 will be as follows:

I. Announcements.

II. Minutes of the previous meeting.

III. Results of DCA and PRB discussions.

Iv. Outcome of the Recommendation for the recruitment of new
arrivals.

v. Any other business. 


\section{A.CA A R \\ VETERINARY SUB-CQMMITTEE \\ Minutes of the meeting held on Tuesday, oct. 20, 1992}

I. Minutes of the previous meeting:

Minutes of the previous meeting were approved.

II - Announcements:

a. UNDP was informed that there are vacancies for 2 DVM in one of the agencies in Quetta. The basic salary will be Rs.A, v00 with Rs. 3,000 field allowance and other benefits.

b. MADERA has prepared a pamphlet briefly describing the definition, signs, damages, prevention and treatment of CONTAGIOUS AGALACTIA. The pamphlet was distributed at the meeting. Similar pamphlets to this one will be prepared for other diseases too.

III. Regults of the negotiations between PRB and DCA about the overlap of their activities in Parwan:

According to the previous talks, the directors of both NGOs agreed to work in their own areas. But in the meeting, it was realized that both agencies are working in the same district which is contradictory to the policy agreed on at the veterinary sub-committee meeting last year. The policy says that only one NGO should work per district.

The sub-committee voted on the issue and with the majority of ( 6 votes out of 7) approved that since DCA has established its clinic in the area earlier, PRB should withdraw from the distrjet.

UNDP distributed the list of the clinics of different NGOs in different parts of Afghanistan and said that the overlap of other projects will be discussed in the next subcommittee meeting. The capacity of a clinic covering a district will also be discussed in that meeting.

IV. Presentation of Dr. Azim Nasseri: According to the previous arrangements Dr. Azim Nasseri,
former professor of Kabul University, attended the meeting.
UNDP is going (cows).

Dr. Nasseri said that 3 courses will be taught, each for. 2 weeks which will train a total number of 36 veterinarians. out of 12 particlpants in each course, 10 will be introduced by the NGOs (GNF-4, IRC-2, PRB-2 and CRAA-2), one Erom the employees of the government and one from the community. The courses will be mostly practical and the trainees will be 


\section{2}

taken to Jalalabad. Materials used for the courses will lit provided. by GAF and other expenses will be pald by UNU! which will be managed by CRAA.

Dr. Nasseri sald that he is willing to train the professional staff of any NGO without any charge where lie will be stationed.

V. Any other business:

Dr. Ph. Leperre, FAo representative in Balkh, participated in the meeting. He said that FAO has been runniug veterinary activities in the following districts of northel provinces:

BALKH: Nahr-i-Shahi, Dehdadi, Mazar-i-Sharif, Dalkh and shortepa.

JAWZJAN: Sheberghan, Aqcha, Faizabad and Sar-i-Pul.

FARYAB: Andkhy, Darzab.

SMANGAN: Aibak, Khulm and Dara-i-Soof.

BAGHLAN: Pul-1-Khumri, Doshi and Kayan.

HARAT: The activities started in Engil district but suspended due to fighting.

FAO plans to open new clinics in Hazrat sultan of Samangan, Shulgara of Balkh, Qaisar and Murghab of Faryab, Qala-i-Naw of Badghis, Faizabad of Badakhshan and Imam Saheb of Kundu: FAO plans to equip each district of the 10 northern provinces with a clinic by 1995.

The medicine is supplied mostly from the European countritis and is sold near to the purchase price. The vaccines were previously supplied from Kabul but this time they will be purchased from other sources. FAO said that the vacointis are sold under normal conditions but at the campaign staga they are given free. FAO believes that the veterinal services should be encouraged towards privatization.

FAO representative said that he was in Bamyan recent:ly and visited GAF clinics. OXFAlf has been working in Yakawlilly and planning to work in Panjab. FAO is going to talk tiv them in this regard.

FAO agreed with the vet. Sub-committee policy "olls: agency/district" and said that they will be in favor $)$ continuing UNDP's policy which has been implementiu! projects through NGOs. 


\section{3}

VI. Any other business:

UNDP requested the concerned NGOs to'talk to that office about the duplicating projects up to the end of the current week. The list was distributed in the meeting.

The at tendants:

Dr. Neil Chesterton (chairman)

Dr. Halimi, Dr. Wassink, Dr. Alemzada

Dr. Sayed Mohammad, Dr. Daud Shah

Dr. Mehraban

Dr. Azim Nasseri

Dr. Bismellah

Dr. S. Ahmadzai, Dr. Shafique, Dr. Bashir Ahmad

Dr. Nousain $\mathrm{i}$

Dr. Ghulam Saeed

Dr. Ph. Leperre

Khalil ur Rahman

COMDEV

DCA

$G \Lambda F$

UNDP

PRB

CRAA

I RC/RPA

MADERA

F $\lambda$ O/Mazar

ACBAR

The agenda for the next meeting which will be held at 8:30 am,
Tuesday, Nov. 3,1992 will be as follows:

I. Minutes of the previous meeting.

II. Announcements.

III. Discussion on the overlapping projects.

IV. Clarification on personnel in a standard VFU.

V. Remarks on MADERA's pamphlet.

VJ. Results of overlap with FAo.

VII. Any other business. 


\section{4 \\ $A C B A R$ \\ VETERIMARY BUA-COMMINUTHE}

Minutes of the meeting held on Tue., Nov. 3,1992

\section{The agenda:}

The agenda was approved.

II. Minutes of the previous meeting:

i. Item IV should read "Dr. Azim Nasseri was Assnciate
professor". i1. 2nd page, 2nd par. should read " $\lambda$ nd visited GAF and DCA
clinics".

\section{Qverlap of clinics:}

The NGOs who have had overlapping projects in a few districts have discussed each situation and the policy of one NGO per district followed.

iv. Personnel of a standard clinic:

In the previous sub-committee meeting the issue of overlap of activities was discussed. It was sald that in case of one NGO per district, the NGO in charge of the district should have enough (standard) personnel to cover the need of the district.

GAF sald that sometimes a second NGo is asked to work in a district where another NGO is already working because the clinic is understaffed to meet the needs of the district. The meeting agreed that this is not a good enough reason for a second NGO to move into a district. Instead, the NGO already in the district should be informed of the problem. One DVM and 2 paravets is a minimum. There should be more personnel for big districts to answer the need of the people of the district.

v. Comments on MADERA's pamphlet:

It was agreed that the lissue should be discussed in the next sub-committee meeting as MADERA was not present.

VI. Overlap with FAO:

It was sald that the issue should be discussed at the next vet. Sub-committee meeting. A map which can show the boundarles of the districts should also be present at the meeting.

To come to closer or even unique pollcy, FAO offlclals of 
Kabul should be contacted. Dr. Frigan of GAF said that he will be meeting Dr. Dewan, chief of the vet. section ol FAO -Kabul, and the result of negotiations with him will be reported to the next Sub-committee meeting.

\section{Any other business:}

a The UNDP papers regarding the Guidelines for the Vaccination of hivestock in Afghanistan and Cope attendants were requested to read them and get prepares to discuss the issue in the next sub-committee metily.

b. For effective coordination of activities, the regular participation of MADERA and ARC was requested.

c. Agencies were asked to. take preparation for the election of new chairman for the veterinary sul. committee. Dr. Neil Chesterton, the present chairfidi, has been carrying out this task for almost 2 years.

d. Dr. Housaini, member of the Technical Comittee fos Hiring, said that since some of the agencies do rol: follow the policies agreed on, he is going to withdicus his name from the membership of this committee.

e. The first course on Pregnancy Test is going to start ui November 10, 1996 in Jalalabad. For more informilion CRAA should be contacted.

f. The meeting agreed that some issues would be mole easily discussed if funders were not present. It all NGO had such an issue all they need to do is to inform the chairinan before the meeting.

\section{The attendants:}

Dr. Neil Chesterton (chairman)

Dr. Halimi, Dr. Gerrit Wassink, Dr. Alemzada

Dr. Bismellah

Dr. Housain 1

Dr. Sayed Mohd, Dr. Daud Shah, Dr. Frigan

Dr. Sanaul Haq Ahmadzal, Dr. Bashir Kahlil ur Rahman

COMDEV
DCA
PRB
IRC
GAF
CRAA
ACBAR

COMDEV

PRB

I RC

CRAA

ACBAR 
Minutes of the meeting held on Tuesday, Dec. 1, 1992

I. Approval of the agenda:

The agenda was approved.

II. Minutes of the previous meeting:

Some more explanation should be added to the section of the mission of UNDP to Mazar-i-Sharif. Members requested expansiof of information under und report to north Afghanistan be included in the minutes.

The followings were added:

i.)... Staff sold very little medicine

Faizabad Clinic - approximately Rs. 1000 of medicine sold in 1 month. Andkhoy Clinic - Afs. 90,000 sold in 3 months ( 2 vet stafE)

Sheberghan Clinic - Afs. 145,000 sold in 5 months ( 3 vet staff)

Doshi Clinic - no medicine sold.

Dr. Mehraban estimated Rs. 283/month/vet was sold. $10 \%$ of this was for salary of staff, the rest to go towards replacement medicine.

ii) Staff did not fully understand program

Dr. Mehraban reported that the training was very short for staff -only 15 days. When questioned "they had no knowledge". It was felt that staff did not understand the program. At one clinic only one out of the 15 trained was still working. No reports were kept of activities, so no monitoring could be, done.

\section{iii) Output low}

This was hased on the fact that from the 6 clinics visited the total medicine sold was Rs. 10,1.75. In Mazar-i-Sharif a maximum of 10 animals per day were being treated by 8 veterinarians.

II Announcements:

Dr. John Woodford of UNDP.-Quetta is going to attend the next meeting of veterinary sub-committee. Therefore, the next meeting will be held a week later than the ordinary schedule (Wednesday, Dec. 22 not Dec. 15, 1992).

IV. Results of the two session of Pregnancy Test course:

According to the phased program, following two weeks courses were arranged:

- The first course was held from Nov. 10 to Nov. 24, 92

- The second course was held from Nov. 25 to Dec.10, 92. 


\section{7}

Nomination for the first course from different NGOs were received in time. The trainees so nominated by the NGos attended the course promptly on due date. On completion of the theoritical period the course in Jalalabad Veterinary Clinic, the trainees were shifled lo the Dairy Caltile Farm, Hada. The first and second days, the farm authorities were very cooperative and good number of cows were available for pregnancy diagnosis and practical demonstration to the trainees. On the third day, few cows were available at the farm and the rest of the animals were said to be in fields. Later-on the matter was discussed with the farm authorities and there was some mis-understanding of the trainees which was settled mutually. However, at Jalalabad veterinary clinic, the practical demonstration of pregnancy test was done very wel1.

For the second two-week course, the response of NGOs was weaker and 8 out of 12 DVMs participated. Then, 4 DVMs from CRAA were introduced to fill-up the gap. Most of the nominees to the course were one day late arriving. The course was therefore delayed by one day.

V. GAF refresher course:

The last ( 4 th) session of the GAF courses for 1992 taught by geust professors from Germany will be split into two sessions, each for a week. The first part will be held in Kabul Erom Dec. 8 to 13 and the second part will start in Peshawar on December 15. The geust professor to the fourth session is Dr. H. Dennig.

For the first session in Kabul, 14 DVMs or assistant DVMs will be received from the government and 10 from GAF from the closest clinics to Kabul.. other agencies can also nominate their field staff of the same level from the clinics close to Kabul. Each trainee will be given Afs. 2000/day. No other costs will be paid.

VI. Any other business:

A. DCA is producing maps of the districts of Afghanistan where their clinics have. been located. Interested agencies can order each for Rs. 500 for other districts.

B. Recently the vaccine production capacity of VRI Peshawar was veiry low. DCA contacted the authorities and they agreed to allow production for Afghanistan. Negotiations will be carrued out about quality.

It was also suggested that in stead of buying vacine from Pakistan or other sources, vaccine production in Kabul should be revitalized.

C. It was stated that one of the agencies have shifted about 14,000 chickens to Wardak. Most of the chickens died. The inroduction of these chickens also spread diseases to the local chickens and caused mortality. sluce fund for the chlckens was provided by undp, this 


\section{8}

UN agency should be. more cautious about similar projects. A letter in this regard will be drafted and will be sent to all concerned agencies after being discussed in the next sub-committee meeting.

D. The Sub-committee showed deep concern over the lack of coordination between FAo veterinary programs and the Sub-committee members. It was suggested that the Veterinary Program Managers should talk about the future of the veterinary. programs considering the hand over of programs from UNDO to FAO with the directors of
their respected NGOs.

The issue of NGOs-FAO future pollcy will be discussed in detail in the next sub-cormittee meeting.

The attendants:

Dr.Neil" Chesterton (chair.)

Dr. Wassink / Dr. Halimi

Dr. Sanaul Haq Ahmadzai

Dr. Ghulam Saeed

CCMDEV

DCA

CRAA

Khalil ur Rahman

MADERA

ACBAR

$\begin{array}{ll}\text { Dr. Shir Aqa } & \text { ARC } \\ \text { Dr. Housaini } & \text { IRC } \\ \text { Dr. Kazem } & \text { RPB } \\ \text { Dr. Sayed Mohammad } & \text { GAF }\end{array}$




\section{9}

\section{A $\mathrm{CAR}$ \\ VETERINARY SUB-COMMITTEE}

The agenda for the next sub-committee meeting which will be held at $8: 30 \mathrm{am}$, Tuesday, Dec. 22, 1992 will be as follows:

I. Approval of the agenda.

II. Minutes of the previous meeting.

I I. Announcement.

IV. Discussion on FAO policy towards the NGOs Vet. programs.

V. Discussion un vaccination policy produced by UNDP-Quetta.

VI. Results of. the fouth session of GAF refresher course.

VII. Any other business. 


\section{$\triangle \mathrm{C} B \mathrm{~B}$ \\ VETERINARY SUB-COMMITTEE \\ Minutes of the meeting:held on Tuesday, Dec. 22, 1992}

I. Minutes of the previous meeting:

Minutes of the previous meeting were approved.

II. Announcements:

Dr. John Woodford, UNDP - Quetta, was supposed to participate in this meeting. He could not attend the meeting because of regard.

II Discussion on PAO policy towards the NGOs Vet. Programs:

On the request of UNDP - Peshawar, the senior representatives of the NGOs involved in vet. programs were requested to attend this meeting in order to discuss the issue of take over of veterinary programs by FAO. UNDP -Quetta was also expected to attend the meeting. Due to the following reasons the discussion over the issue was postponed for
another time;

i. Absence of Dr. John Woodford

i. i. The chairman of the Sub-committee carried out some discussjon with the directors of some NGOs as well as the Director of ACBAR. It was promised by the Director of ACBAR to facilitate a meeting of the Concerned NGOs with David Lockwood. This meeting is expected to take place in the near future. The results of this meeting will be reported in one of the future sub-committee meetings.

IV. Report on GAF refresher course:

The fourth GAF refresher course, by a German professor, was supposed to be hela in first in kabul and then repeated in Feshawar. The first week course was going to start Dec. I5 in Kabul but due to fighting the professor and other accompanying stafe were stuck in Jalalabad and could not go to Kabul. Waiting for 3 to 4 days in Jalalabad the team returned to Peshawar. The package of materials to be taught

The course in peshawar started on ... and continued for 5 days. The main topics aiscussed in the course was blood
parasites.

DCA expressed its dissatisfaction with the course and said that program was more theoretical than being practical and suitable to the needs of the country. But. GAF said that acrording to the final evaluation, most of the trainees were the guest professor shoul DCh suggested that in similar cases the needs of the trajnecs prior to the starting of a course. 


\section{1}

V. Comments of GAF and some other agencies on the sign board Fox UNop-funded projects:

The design of the new sign boards prerared by Uivoo/ops for their funded projects was a matter discussion for GaF and sone other NGOs. Previously, the nane of the implementing agency was the main part of the board and at the end of the board donor was mentioned. The new sign boards prepared by UNDP/OPS is opposite to the first in which donor's name' is in bold letters on top of the board and the implementor is at the end. UNDP said that this is done in order to bring uniformity.

VI. Irlip charts prepared by UNDP:

UNDP -Quetta with the assistance of MCI has prepared Flip charts providing some information for BVWs. Some explanation was supposed to be given about the chart in this meeting. The sub-committee suggested that the charts should be demonstrated under a special program not in regular rneting.

Agencies can get the needed number of charts from UNDP.

VII. Any other business:

CRAA distributed a summary sheet about the 3 sessions workshop hela under the name of Clinical Diagnosis of pregnency Test in Cows. Some more information in this regard will be given in the next meeting.

The attendants:

Dr. Niel Chesterton (chairman)

Dr. Sayed Aqa / Juhn Myers

Eng. Kabir / Dr. Kazem

Merajuldin

Dr. Mehraban / Dr. Ebrabilli / Dr. Safi

Dr. Sayed Moha / Dr. Daud Shah

Dr. Housaini

Baroukzai / Iebures / Dr. Gh. Saeed

Ajmal Sherzai

Eng. Bilal Ahrnad

Dr. Sanaul. Haq Ahmadzai / Dr. Shafiq

Khalil ur Rahman.

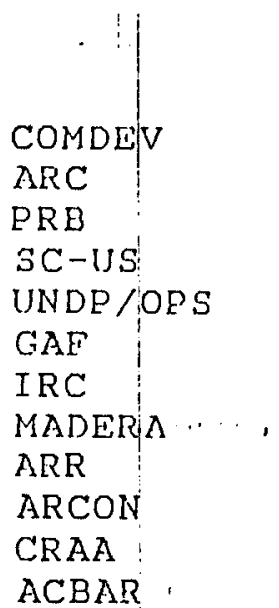



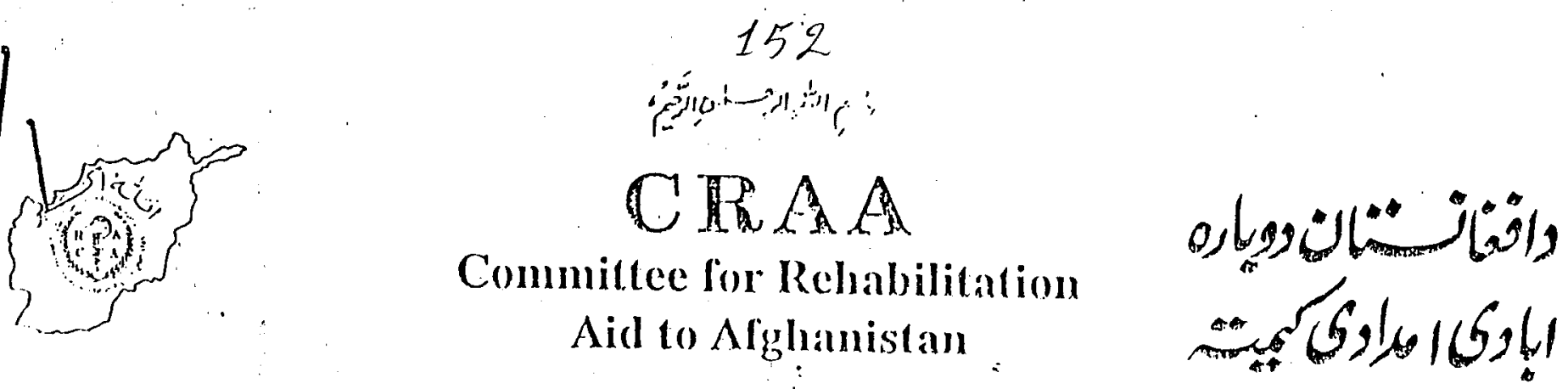

FILLD MISSIGN REFORT NANGAFHAR FHOVINCT.

In light of the decision taken in ACBAR meeting that GAF, DA and CRAA to investipate the cause of outbroak of - k...eCPP and Pasturollosis. Accordingly investifralion Team of this Committee comprising of Dr. Mohammad Shafique, DVM, Monitor and Dr. Wahidullah, DVM Mr. Mir Wais, Asstt: Doctor and Mirza Gul Para Vet were deputed to Nangarbar Frovince to carry out the survey of Ghani Khel, Achine, Naziar, Dur Baba Barikote and Kote (area where Field Units of this Organisation have been establushed.

According to the report of the team, there was no sign of outbreak of the acorementioned diseases in the area except two samples from sheep at vaillage Baishrilock were collected by the team.

The Samples were sent to Veterinary Research Institute, Feshawar on Ist. February 1992 for laboratory Examination. The contentis of the report are re-produced below:-

" Lung No.1 (rroin mature sheep)

Hemophijus isolnted.

Ling No.2 (rrom young sheep)

No erowth obtained."

The matter was also disoussed with birector, V.R.I. Feshawar who advised that no serum j.s requj.red to be male at this stage.

On 2nd Tebruary, 1992 the team surveyed Shadal, Ardul Khel, Kandaro, Miangan \& Tara Khel area. Trom villape Pekha a lung from a Goat was also examined by the leam. 'The symboms narrated by the owner of the animal before and after death was just like CCPP. Auto Vaccine on the followine, cormula was prepared on the spot.

$i \mathrm{Gm} \mathrm{tissue}+1 \mathrm{Gm}$ Pormaline + $100 \mathrm{CC}$ normat salino 
The Auto Vaccine was administered in the clock of Lala Jan and Meera Khan. No side arfect was reported. $\Lambda$ bout 150. heads of goats were vaccinated with Auto Vaccine, as well as Teramycin were also applied for a group of sick animals. The result of the vaccination was quite encouraging and about $80 \%$ or the animals in the flock were protected. Keeping inview the result so achieved, more animals ere also vaccinated in - Kandar and Sandook villages.

The investipation is still in process in the rield and further progress so achieved will be reported in due course of time. 


\section{4}

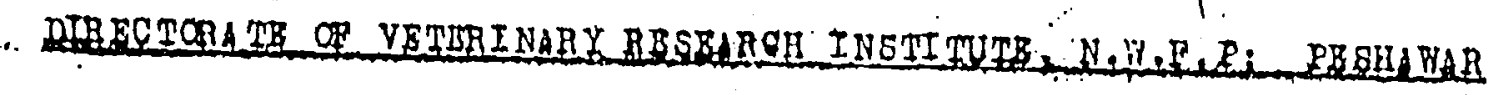

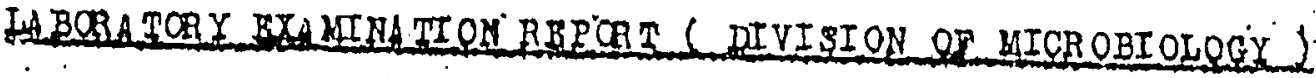

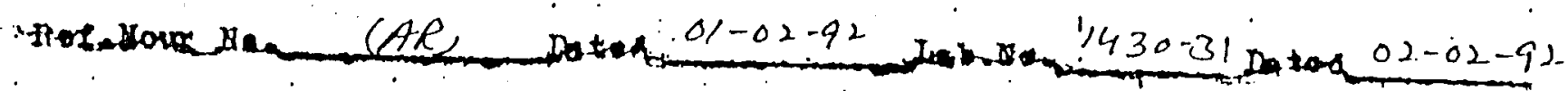

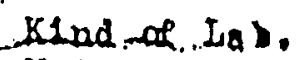

Ha tex dei heondrad

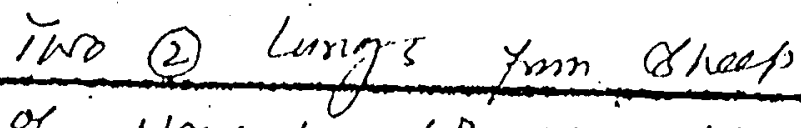

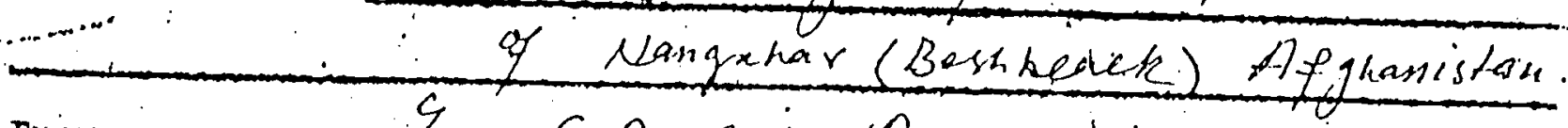

Fxum C.R.A.A. Sorkarat.

Examined for

Bacteriza

121100 an

Rosult Lung $110-1=$ thamothieus tsolecteac.

Rpootrod on

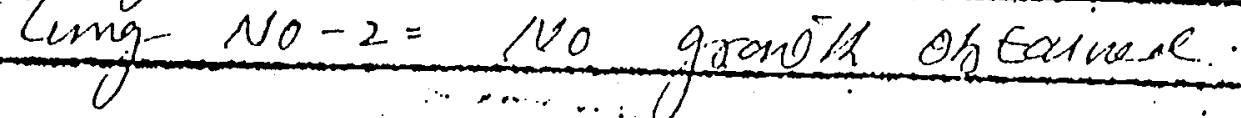

RBMARKS.

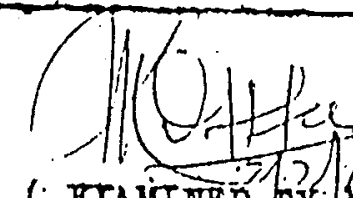

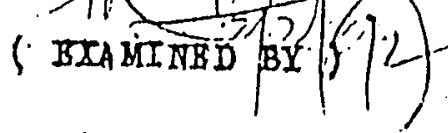

$\sqrt{2}$ 
155 


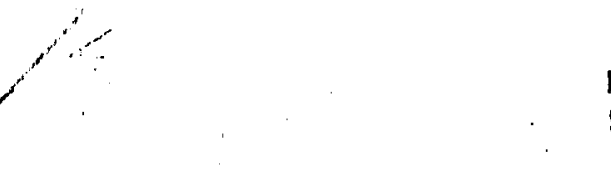


NGO VETERINARY CROSS BORDER ACTIVITIES

SUPPORTED BY UNDP OR OTHER SOURCES

NGOPROJ

Rev. Dates 18.03.1992

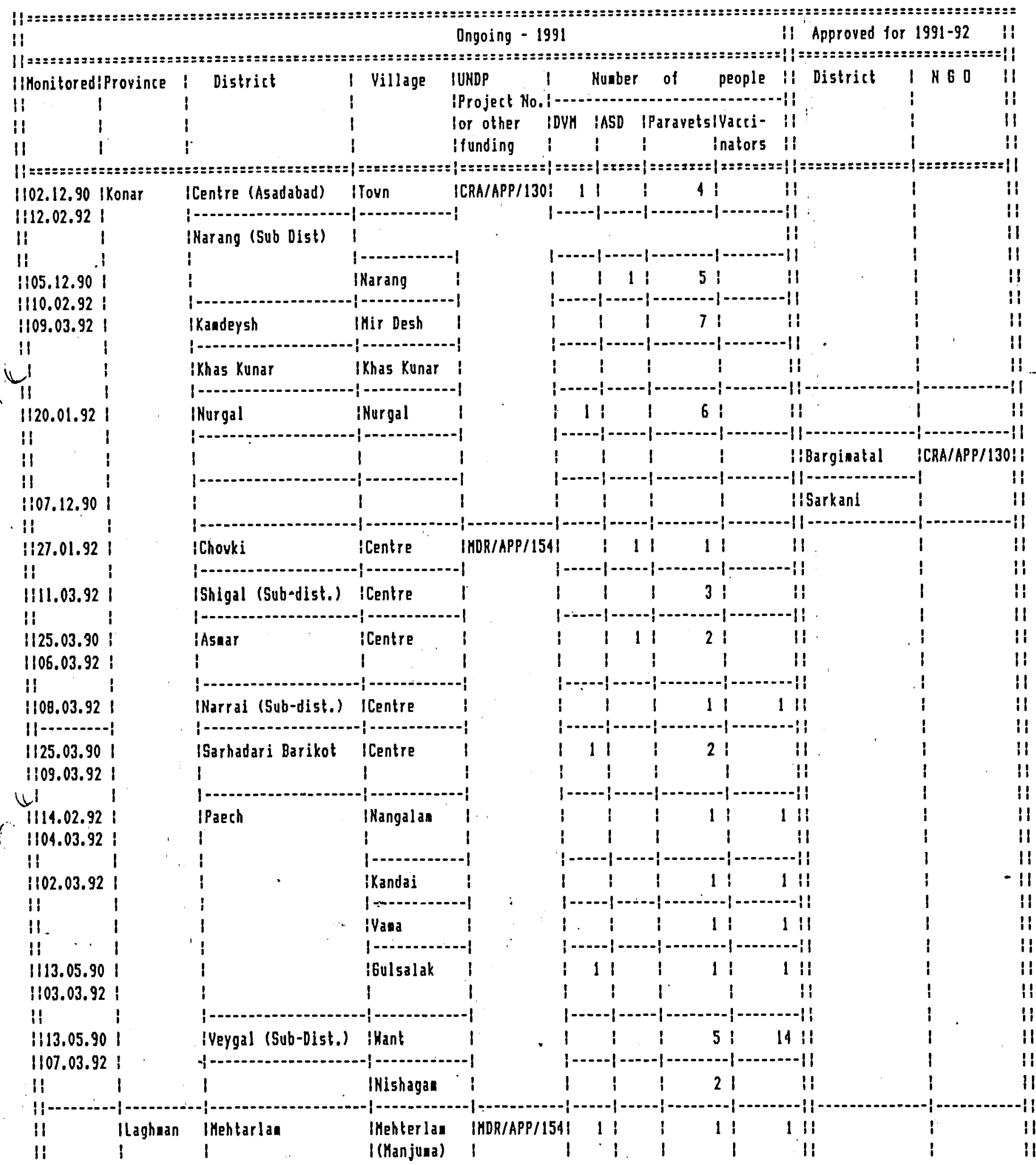


11

1107.07 .91

i128.12.91:

11

$1126.12 .91 ;$

II

1130.12 .911

11

11

11

11

11

11

$125.12 .91 \quad$

11

\|26.12.91 |

i! i

$\$ 124.12 .91:$

11

$|123.12 .91|$

1

11

11

11

$|123.12 .91|$

i1

$-1128,12.911$

$\begin{array}{ll}1 & \text { Village } \\ 1 & \vdots\end{array}$

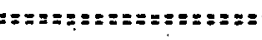

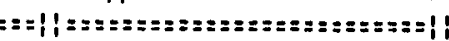

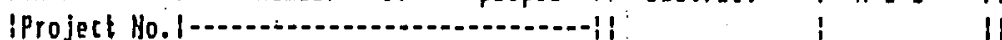

lor other IDVH IASD IParavetsiVacti- If'

lfunding if 1 i inators if

:

\begin{tabular}{|c|c|c|c|c|c|c|c|}
\hline | - - & $-1-\ldots-1$ & & $\cdots-\cdots \cdot$ & $\cdots-\cdot-$ & $\cdots--$ & $-\cdots 11$ & i \\
\hline Khogiani & ILazikali & 1 & 11 & 1 & $2 i$ & 111 & 1 \\
\hline 1 & 1 & I & 1 & 1 & ! & i1 & i \\
\hline & & & $\cdots--1$ & & & & i \\
\hline IKheva & ICenter & IGAF/APP//53! & I & $!$ & 11 & i: & i \\
\hline ; & - & & $-\cdots--1$ & $---i-$ & $---1-$ & $---i i$ & i \\
\hline I Hesarak & ICenter & :DCA/APP/IЗ马! & 1 & 11 & 11 & 111 & i \\
\hline 1 & I Naver & 1 & ! & ! & 1 & if & i \\
\hline
\end{tabular}

iGovshtah 1 IGAF/APP/1531 1 i 1 iGAF/APP/153I:

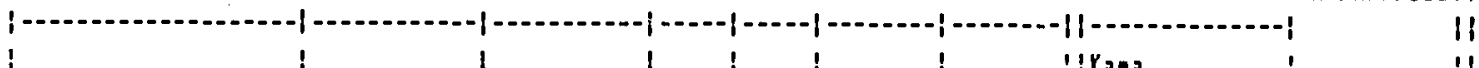

11

iNazian ISarobi ICRA/APP/1301

1!31.12.90 iPakteka.

1129.07 .91 :

it

$1110.09 .91 ;$

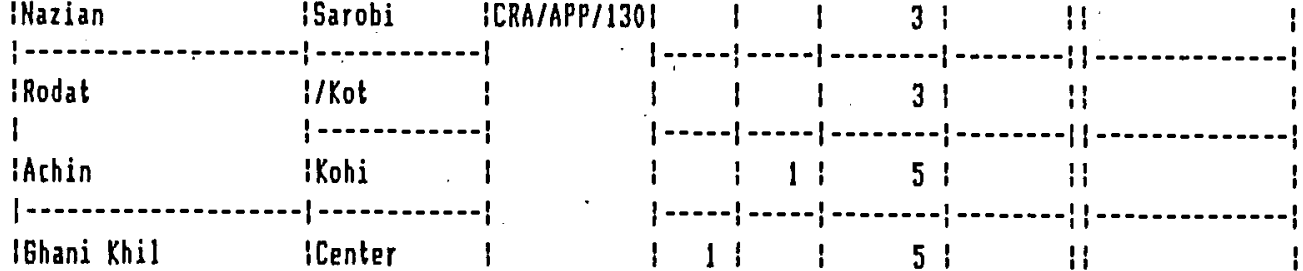

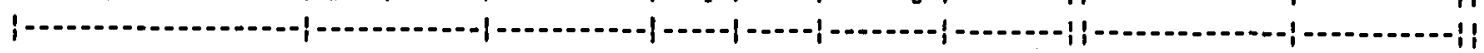

$1 \quad 1 \quad 1 \quad 1 \quad 1$ lisurkhrood ICRA/APP/II301:

i

$\mid$
1

ILalpora IGAF/APP/153: $1,1 \quad 1 \quad 2 i \quad 11 \quad$ it

IChaparhar

1

IUrgoun IUrgoun Iovn IGAF/APP/153! 111 . 31 i

$\begin{array}{lllllll}1 & 1 & 1 & 1 & 1 & 11\end{array}$

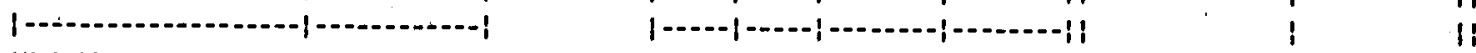

Motakhan $\quad 1 \quad$ i $1: 31$ il

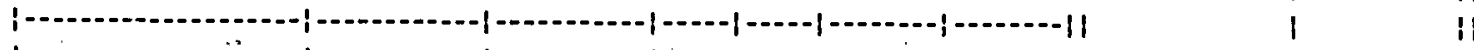

$\begin{array}{lllllllllll}1 & \cdots & 1 & 1 & 1 & 1 & 1 & 11 & -11\end{array}$

IHazahkhuah IMinziy ${ }^{*}$ IOCA/APP/I39i $\quad 1 \quad 1 i$ il i

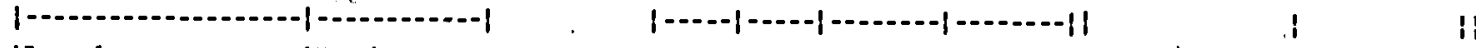

Baral Margha $\quad$ i $11 i \quad 1 \quad 1 \quad 111 \quad$ it

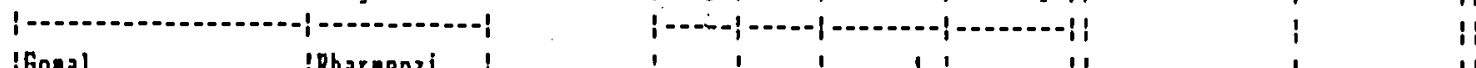

igonal TRharmenzi 1 i 1 i 11 it il

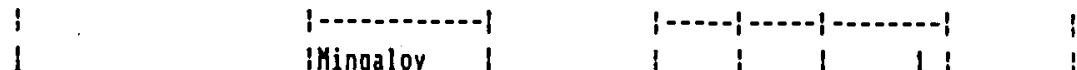

$1 \quad$ ilingaloy

il

11

i

1

i! 
NGO VETERINARY CRDSS BORDER ACTIVITIES SUPPORTED BY UNDP DR DTHER SOURCES
NGOPROJ

Rev. Date: 18.03.1932

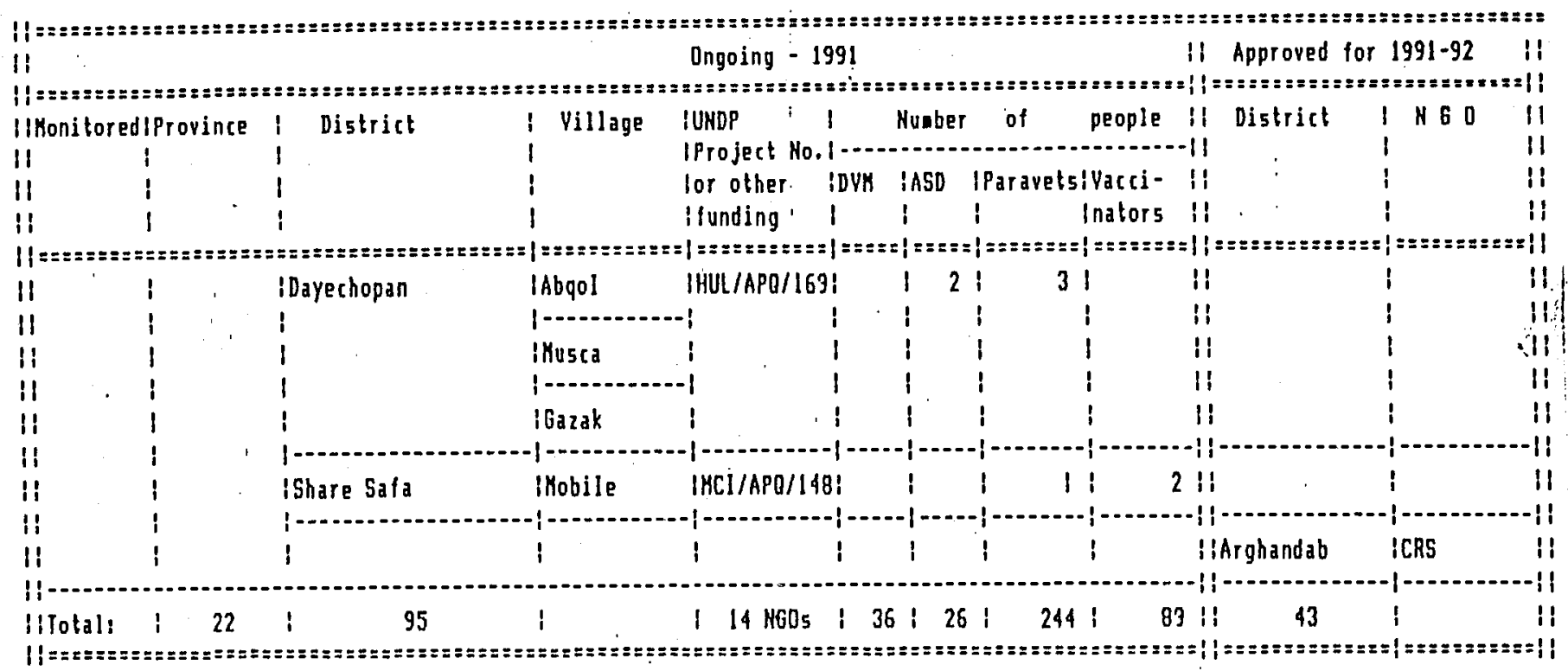

\section{Abbreviations:}

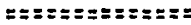

OVK: Doctor of Veterinary Hedicines.

ASD: Assistant Doctor.

Note: Ongoing 1991 districts vill also be covered under $1991-92$ projects

- KADERA operation is partially conly paccination aspects) is funded by UNDP, 50 it is difficull to separate UNDP and EEC coverage.

- Under 1991-92 all NGD operations except 5 VFU 5 of GAF, 6 VFU5 of DCA, and 2 vaccinators of NCA are funded by UNDP. Indoors operates under its ovn funding. 
May 26,1992

Dear Sir/Madam:

Today it was with great alarm that we received news that the UNDP/OPS Veterinary Programme for Afghanistan will only receive funding for seven more months. We had no warning of this and we feel you may not appreciate the impact such a quick decieion, withóut any warning to NGOs, will have.

Many aspects of preparing veterinary projects make long term planning essential. For example, right now in Peshawar 25 people are part-way through a five-month training course funded by UNDP/OPS in order to staff clinics all over Afghanistan. Another 25 have just arrived to register for a second course. 6 are part-way through a special course designed with the request of UNDP/OPS to be trained a supervisors for clinics desperately needed in rural Afghanistan. 25 others have funding from UNDP/OPS for their course later in 1992. To sucldenly stop funding shows disregard for NGOs that have been prepared to plan with UNDP/OPS for the long term benefit of Afghanistan.

13 NGOs in Peshawar (and Quetta) have also taken risks together with UNDP/OPS to help work towards sustainable veterinary services for Afghanistan in the following ways:

1. Veterinary programmes were started in 1987 by MGOS and assistance given by UNDP/OPS in 1889. These programmes were initially without charge, to expose farmers to the benefit of veterinary services.

2. In 1991, all NGOs began working on recovery of $40 \%$ of the cost of medicines.

3. In 1992 al I NGOs agreed to increase the percentage retovery of the cost of inedicine $1: 080 \%$ with aim inf self sustainability of clinics.

4. All NGOs agreed to plan for $100 \%$ recovery af medicine by 1994 .

5. In 1991 all NGOs included BVWs in their programines to increase village input. BVWs do not receive salaries from NGOs.

We appeal to UNDP to consider our case by giving us more notice before funding is finally eut (which we agree must happen eventual ly). 


\section{7}

To cut funds without notice will affect:

* 113 districts and 20 provinces serviced by veterinary field units.

* $\quad 17$ DVMs and vet assistants.

* 254 paravets.

* 89 vaccinators.

* 300 (approximately) BVWs who work with the qualified staff (after one to two more years they would have a major impact on village based veterinary services):

* 2,260,000 vaccinations minimum per year against serious diseases.

* 565,000 treatments - particularly preventative treatment against internal and external parasite.

The next 18 months is vital to keep the impetus going to develop what seem like an impossibility in Afghanistan not too long ago a self sustainable veterinary service.

Please investigate further the impressive coordination and team work between NGOs in Peshawar and the UNDP and reconsider your decision to abruptly cut funds as announced today in Peshawar.

Yours Sincerely,

Dr. Neil Chesterton BVSc (Sydney)

Chairman ACBAR Veterinary Coordination, Peshawar 


\section{8}

UNITED NATIONS DEVELOPMENT PROGRAMME

OFFICE FOR PROJECT SERVICES AFGHANISTAN PROJECTS OFFICE

P.O. Box 776, 4th Floor, Gul Hajl Plaza, Jamrud Road, Peshawar, PAKISTAN

Date :

Ref :

10.02 .1992

LBMACBO 1

To: Hajt Khalil

2 Rehman Baba Road

University Town,

Peshawar, Pakistan

Dear Hafi:

Subject: Vaccination Procedure - Enterotoxaemia.

Please find attached coples of John Woodford and NJL Gilmour letters regarding the above mentioned subject.

I would like you to distribute them to the veterinary coordination members along with the meeting minutes for discussion in one
of our next meetings.

Sincerly yours,

Dr. Abdui Baq1 Mehraban

Senior Veterinary Officer UNDP/OPS/APO 
Directors: Prof I D Aitken, Dr P van den Broek, G B R Gray, obe, J Jefrey, ;

R J LENNOX OBE, M J MACKENZIE, J STOBO OBE

Our relerence:

Your relerence:

Date:

Mr John D Woodford BVM MSC MRCVS UNDP/OPS (quetta)

$P$ O Box 1051

Islamabad

Pakistan

Dear Mr Woodford

Moredun Regearch Insillute 408 Gilmerton Road '

Edinburgh : EH17 7JH

Tolephone : 031-664 3262

Facsimile : $031-6648001$

With regard to your questions in your letter of 6.11 .91 I have attempted to answer them in the same order as you used in that letter.

1. One vaccination of ewes in late pregnancy ( 4 weeks before lambing) would only be adequate if the ewes'had previously been vaccinated twice at a $4-6$ week interval.

2. The literature on this is sparse and unclear. colostrally-acquired antibodies have usually waned by 2 - 3 months when lambs are vaccinated with clostridial vaccines.

3.-...Lambs are competant from birth.

4. I'suggest that a simple experiment could be designed to investigate this using serology (see 6 below).

5. Two doses of vaccine are required.

6. Serological tests would be adequate to monitor the immune status but few laboratories do these routinely; certainly not here. Clostridial vaccine manufacturers are the mostly likely people to be able to help since they use serology in quality control of their vaccines. Hoechst Animal Health, Walton Manor, Milton Keynes, MK7 $7 \mathrm{AJ}$ would be worth contacting.

I hope my comments have been of use. We have much the same problem with pasteurella vaccines and in combined pasteurella and clostridia vaccines. We have shown that it is possible to vaccinate very young lambs with pasteurella vaccines without interference from pre-existing antibodies. , : !

Yours sincerely,

$$
\text { wh lighum. }
$$




\title{
171
}

Qt.e.t:

\author{
United Nations Development Programme \\ Afghanistan projects. Office \\ Quetta
}

Interor̃fice Memorandum

To :

A.B. Mehraban

Date: 2.9 .12 .91

Senior Veterinary officer

From:

Peshawar

Ref : MJWMEOO6

John Wood ford.

Programe VeE

Quetta

Subject: Vaccination proceaure - Enterotoxaemia -

Please find attached two copies of ietiers regaraing the above mentioned subject.

I have also discussed this issue with $\bar{\nu} r$. David Sherman

(Associate Professor, Large Änima i riedicine, Tufts University.

The following important points emerge irom tine letters and discussions.

1) Pregnant ewes should be vaccinated Tí $\mathrm{I} E$ during pregnancy, the second injection being given, ideally, 4-6 weeks before parturition, 'in order to produce suríricient colostral antibodies to protect lambs against, especially Lamb dyssentery, but also

classical Enterotoxaemia.

2) a. Lambs are immunologicaiiy competent from birth onwards and, b. There is no documented eviaence tinat the presence of maternally derived antibodies can interiere with an immunisation given by injection. This is aiso true ror all the bacterial vaccines, toxoids that are routineiy given to sheep and goats. IT IS THEREFORE POSSIBLE TO VACCINATE LAMBS $A S$ EARLY AS 1 MONTII OF AGE AGAINST ANTHRAX, ENTERUTOXÁEMIÁ ÜK BLACKQUARTER.

3) TWO DOSES OF VACCINE (AT A 3 WEEK INTERVAL) ARE REQUIRED FOR LAMBG TO DEVELOP A FULLY PROTECTIVE LEVEL OF IMMUNITY.

4) I have written to Hoechst innimai Health to make enquiries regarding serological tests.

5) The above information should be incorporated into any future guidelines for NGO's.

With. best regards. 


\author{
$A C \mathrm{~B} A \mathrm{R}$ \\ VETERINARY COURDINATION \\ Minutes of the meeting held \\ on Tuesday, Jan. 8, 1991 in ACBAR
}

\title{
Attendants:
}

Dr. Mohd. Zaher

Neil Chesterton

Habibullah Rashidi

Ebrahimi

Bob Sattan

Dur Mohammad

Gerrit Wassink

Daud Shah

Khalil Rahman

RONCO
COMDEV
DCA
UNDP
WVA
AIRC
DCA
GAF

ACBAR
Masood Khelwati

Erik Jacobs

Mehraban

Dr.Ghulam Saeed

Ahmadi

Bert Bosch

Sayed Mohammad

Dr.Zaker
DCA

DCA

UNDP

MADERA

ARC

DA I

GAF

GAF

\section{Announcements:}

According to the request from SWABAC Mr.Mehraban of UNDP $\checkmark i s i t e d$ this coordination council in Quetta. So for MCI, SCF and CRF have been carrying out veterinary services in that zone. They had some questions about veterinary and Dr.Mehraban answered their questions and talked to them regarding their problems. Dr.Mehraban stated that the main problem with SWABAC NGOs doing veterinary activities is the lack of professional veterinarians. He promised the SWABAC that some veterinarians in Peshawar will be persuaded to go
to Quetta.

SWABAC praised the successful continuation of the ACBAR veterinary coordination meetings and once again asked for receiving minutes of this coordination group.

II. List of the subjects for the next DCA training course: It was said DCA will make a plan and give to the other
NGO's. They can give their opinion on it.

III - Result of negotiations between ARC and GAF:

The protilem of both NGOS is that each NGO's work is overlapping another in Chärkh and Baraki districts of Logar province and UNDP as a donor agency asked that one of them should leave the district.

In the last meeting of the Veterinary Coordination they were requested to discuss the problem between themselves and report it to the meeting of Jan.8. 
The two NGOs had some talks but was not fruitful. ARC proposed the following 2 alternatives:

A. Bath NGOs should divide the villages 'of the
districts.

B. Each NGO should select one district and should set-up its program in that district.

The first suggestion was not accepted by UNDP, because UNDP says that one NGO should cover the services of the whole district and not more than one NGO should work in a district while the neighboring district does not receive services at all. UNDP says it's not time for comprehensive activities. The secand suggestion for GAF was not acceptable. GAF says that leaving of either of the districts is difficult for it, because GAF has received fund for both districts from German government and clarifying the problem with German government requires time. GAF asked ARC to leave these districts and go somewhere else, because GAF has been working in these districts since 1987 and ARC was funded by UNDP in 1990 for its projects.

After a long discussion GAF said it will contact its head quarter in Germany. ARC is willing to move to either one of the districts. Finally both organizations and UNDP agreed to let the problem be finalized in the next meeting.

IV. Addresses of diaqnostic labs. outside Pakistan:

DCA sent samples to Veterinary Research Institute (VRI) Peshawar and Lahore to be diagnosed but they couldn't. So it was suggested if possible to contact some foreign labs. DCA has received the address of one of the French labs which is copied below. 
174

it

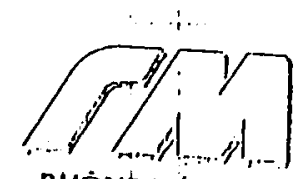

RIIÓNE MERIEUX

17. rue Bourgelat 69002 Lyon - FRANCE

Tél. 72.72.30.00 - Télex RM 375887 F

AFFILIATED MEMBER OF THE WOLLD VETEIRINARY ASSOCIATION

$!$

Dn. KHUNAAM SHAFI KHAN

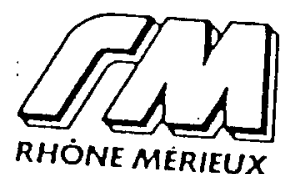

(RP RHONE-POULENC

IM- Antrinal ilonilit Division

MHONE-POULEHC PAKISTAN (PVT) LTD.

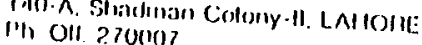

[May \& Baker] 


\section{6}

\section{A $C B A R$ \\ VETERINAFRY COORD INATION}

Minutes of the meeting held on Tuesday, Jan .22,...1991 in .ACBAR

Attendants:

if

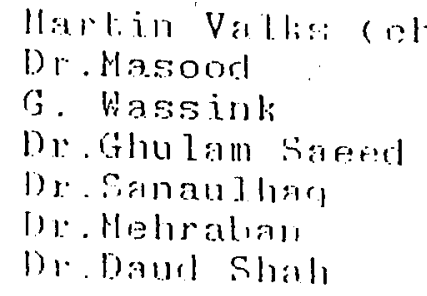

I. Announcement:s:

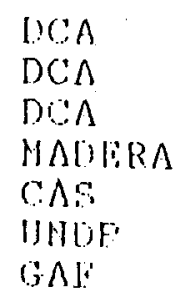
1.). H. . B aloy
Abrd. Manan
Fivir? d arobei
Dr. ilıafir
D). Siateal Hulw.
Vr. Ehrma i mi
Kha Jil. Raluman

RONCOI
SCA
DCA
CAS
GAF
UNDP
SCBAR

A. HII) has provirlerd the list af the HGOs which aje? having/are going to have veterinaly arvices in quetta and wijl be distribuled to the memieres.

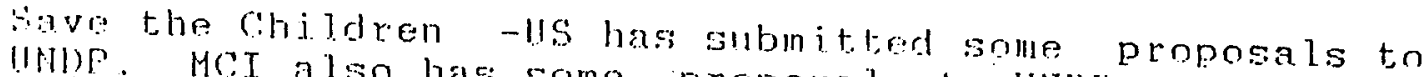

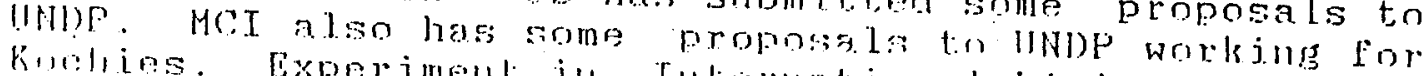

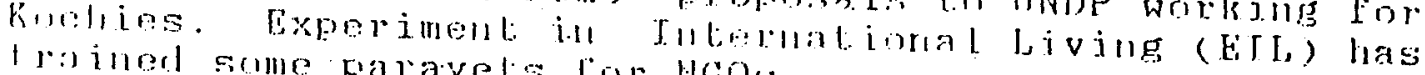

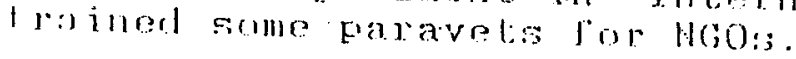

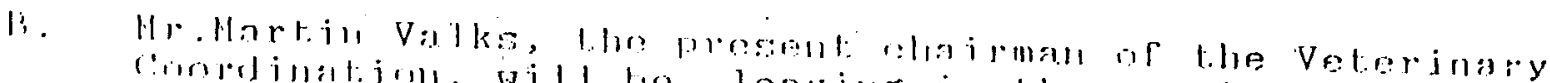

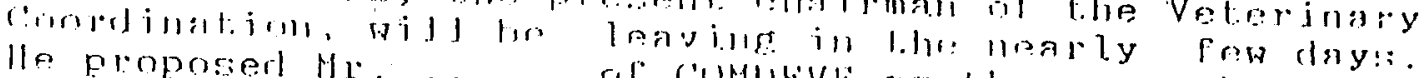

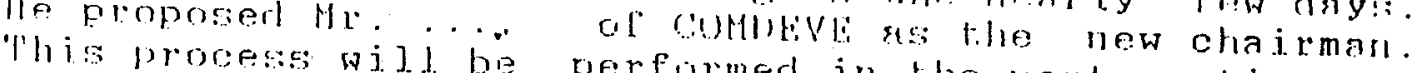
the coordination crimit: peromed in the loxt meeting of

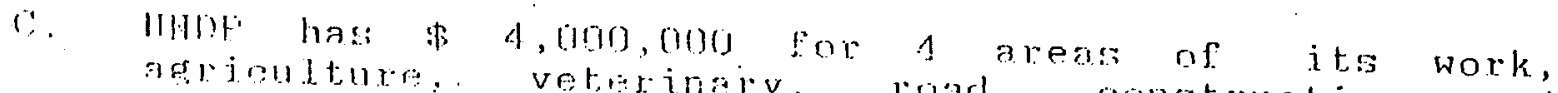

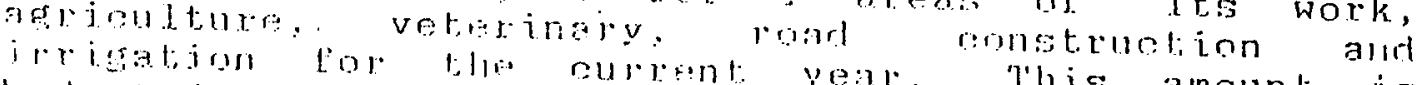

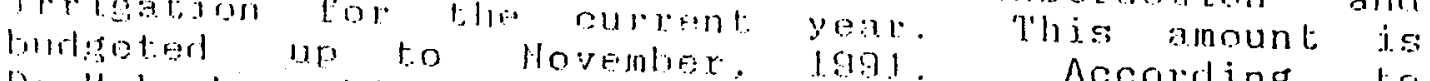

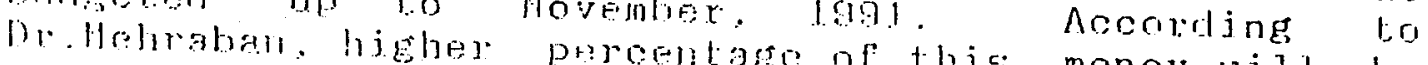

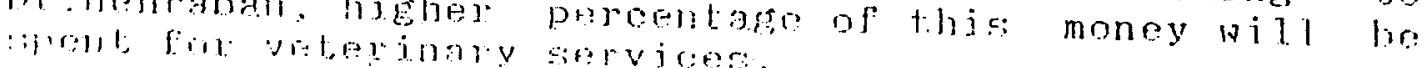

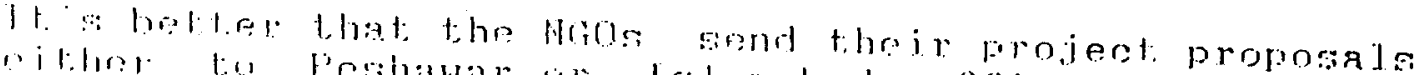

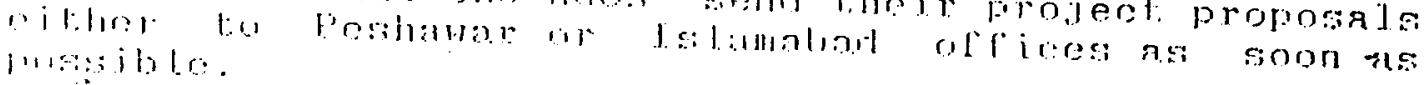

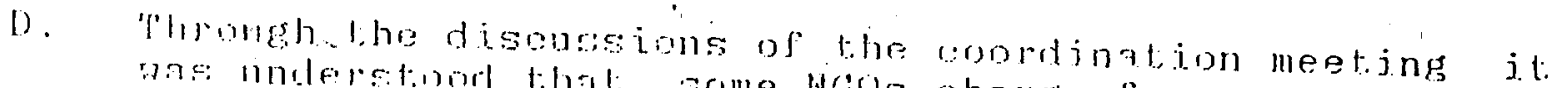
ba

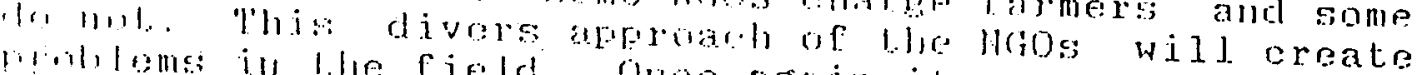

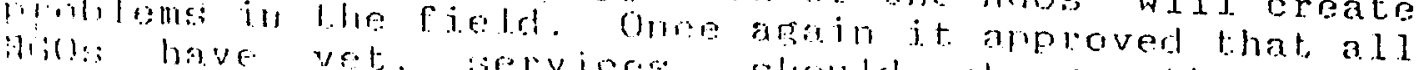

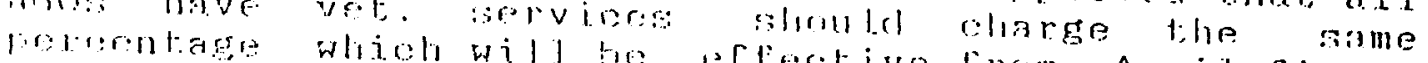
$1: 1 ! 11$. 


\section{7}

E. Howerian rommitbee for Mfghanistan (NCA) has some velerinary activjties and they should be invited to rarticipate in thr regular meotings: of the Corordjuation

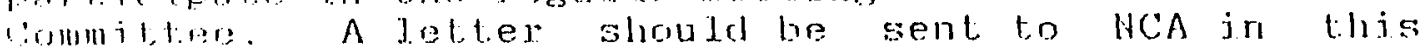
1. Qgesird.

II. Result. of the negotiations between $A R C$ and $G \triangle E$ :

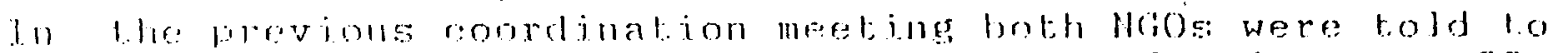
mognliate and report lo the meeting of lanuary $2 \%$.

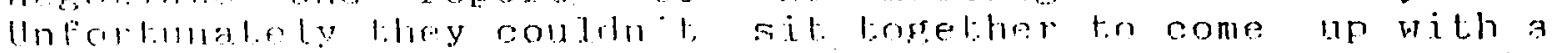

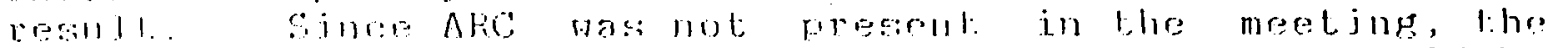

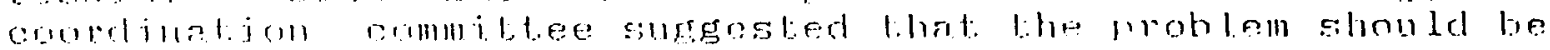

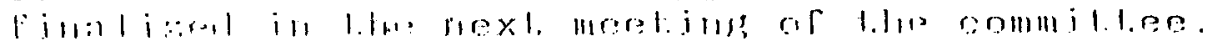

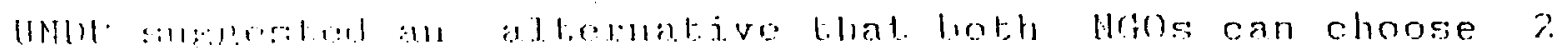
othes. distrjols and extend their abtivjties to them by the salll. linld.

III. Discussion on salarjes and allowances:

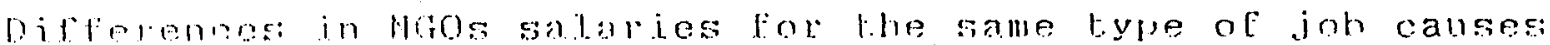
instialililiges among the NGOs. jherelone, it has been Hecided bn chorse a single polioy regarding this impoltant. matra. 'llue lojlowing scales wexe chosen as the highest. limit for fijeld personnel:

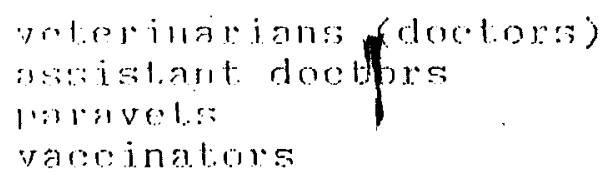

$\operatorname{Ra} 1,650$

This anomul. wj.l include all other benefits. 


\section{$A \quad C \quad B \quad A \quad R$ \\ VETER I NARY COORD INAT ION}

Minutes of the meeting held

on Tuesday, Feb. 12, 1991 in ACBAR

\section{Attendants:}

Mei] Chosterton Masond kinel wat.i Erik Jacolys Ab. Manan Dr.Abulul 7ahir Daud Shah Fllalil Ralman (chair.) COMI)FV DCA

DCA

SCn

CAS

GAF

neinnir
Mohihul lah |lal i m j.

Gerit: Wassink

Dur lolnammad

Dr. Elirahioni.

Dr. S. Ahamrliai

Dr. Ghulam Sapod
$\operatorname{IDC}$

DC:n

ARC:

UNIIP

CAS

MAISERA

I. Announcements:

A. DCA has received some information from Helmand which

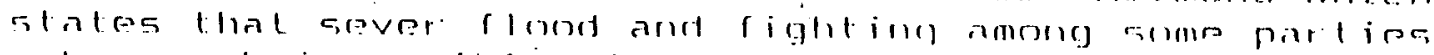

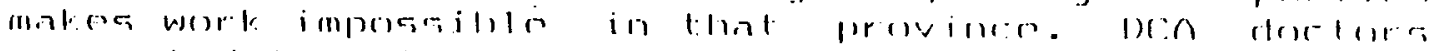
requested to willodraw from llelmands.

B. Dr.tlalimi of DCA mentioned that a human hospital located in Shamshatoo Camp was previously funded by K.liwaiti sources. Since the orcupation of kuwait by Iran, fund to the hospital has heron rrozen. The huspital is equipped wilis al basir: llepeds and staffe It needs only money to be run. If any agency is interested can contact Mr.llal imi al: DCA.

\section{I1. Electing New Chairman:}

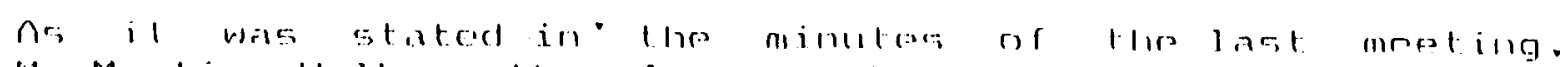
Mr.Martin Valks, the former chairman of the velerinary Coordination, left Pakistan. The former chairman nominated Mr.Neil chesterton of ComDEV as the new chairman. The matter was put for election and Mr.Neil Chesterton was unaminnuely plected as the nou chairman. Mrechertertm asked for assistant and asked if lor.talimi would be assistant chairinan. lle acrepterl.

II Movement of Kochies in Maroof:

ARC said that they feel the need of having, more veterinary slarf in Maroof distrirt of Kanclahar provinre, hecallep hesicles many resident of this district has an avrorage of 100 animals per fanily, a big population of Fochies move through the ligtrict which doubles the mumber of animals in the arpa

" for i leriol of lime. These Kochies have srasomal movements

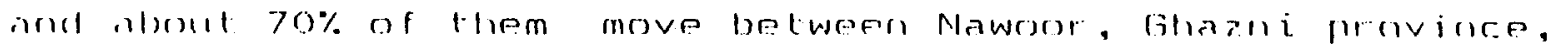
and ihob of Pakjstan. nctually lhere is llo high disease rate in the area due to dry weather, hut some dispasce could

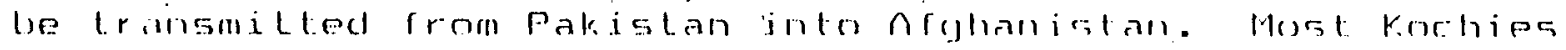


complain of Anthrax and Enterotoxemia. ARC suggests that Maruer will be the, best place to vaccinale these animals."

The same kind of movements exist in Logar province. GnF work in Mrinandara of Nangarlar province and serse llw? problen there. GAf has been working oul lhe filuben by cutting maget from other projects and spending it in Momandara.

CMl in Whella las starled training village worterer (herdsmen) low lo vaccinale the ir animals. rlis kind of training requires large amounts of money which will be difficult to be funded by lindpe or any other donors. It was suggested if part of this money could be raised from the fee and other rharges on fatremes.

IV. Result of the negotiation between ARC and GAF:

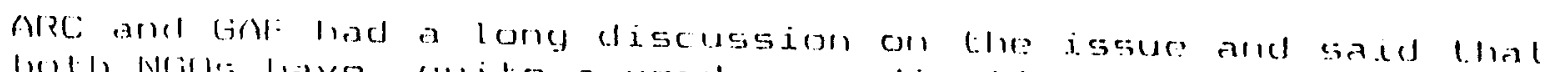

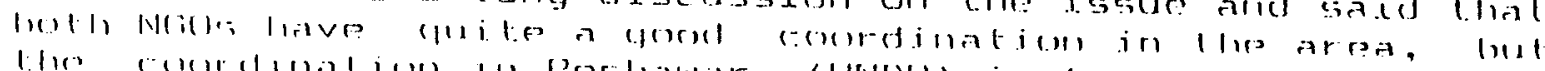

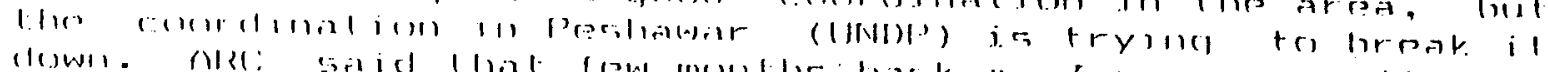

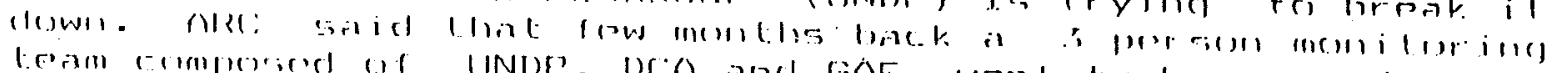

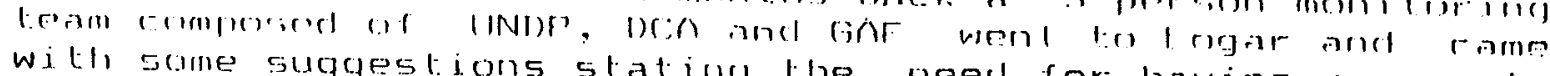
with zome suggestions stating the need for having more vet.
services. ARC was in lihe loam, why does, since the representative of UNDP NGOs from the area. of staff in these two distrigts mentioned the large number

ARC has a rural development program in the area which

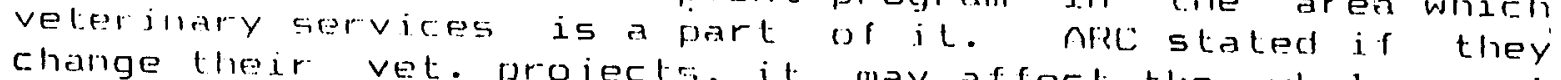
development program.

At lasl. it was suggested that the Veterjnary coordination should send a letier to both UNDP and German Government and Charkh). The letter wotion of the districts (Baraki and having one agency responsible for explain Ac:BAR's policy of agencics should be urged to continue tiste Roth dmor enable lleir fiele steff: to contimue their funding and service under this policy to thesente lo mowide thr goocl coordination meeting felt these districts. The ACHAR the stafr in Peshawar, who hp bether from them wolld hell agencies vould be rejuctant to this lime felt their donor one agenry per distrjet. Dr Dauds to ACBAR's moliry of Mohammal (AIRC) agreed during the meeting to (GNF) and Mr. Dur 


\section{0 \\ $A \quad C \quad B \quad A \quad R$ \\ VETER INARY COORD INATION}

Minutes of the meeting held

on Tuesday, February 26,1991 in ACBAR

Attendants:

Neil Chesterton (chairman)

Dr. Daud Shah

Dr.Mohebullah Halimi

Abdul Manan

Dur Mohammad

K.halil Rahman

$\begin{array}{lll}\text { COMDEV } & \text { Dr.Mehraban } & \text { UNDP } \\ \text { GAF } & \text { Dr.Sanulhaq } & \text { CAS } \\ \text { DCA } & \text { Dr.Masood } & \text { DCA } \\ \text { SCA } & \text { Erik Jacobs } & \text { DCA } \\ \text { ARC } & \text { Dr.Sayed Aqa } & \text { ARC } \\ \text { ACBAR } & & \end{array}$

\section{Announcements:}

Dr.Mehraban of UNDP had some comments on the minutes of the previous meeting.

a. on second page, third paragraph IMC not CMI.

b. IMC has proposed training shepherds, not started.

c. In the meeting of Feb. 12, ARC and GAF both said that they have close coordination in field activities in Logar province, but the coordination in Peshawar which meant UNDP is breaking their field coordination. UNDP defended itself and stated that it does not have the intention of breaking NGOs' coordination.

II: Discussion over the local allowances:

Although the salary for veterinary field staff was fixed in one of the previous meetings, the situation of those field staff who should be shifted to a newly established clinic in a remote area or from one district or province to another is different. It was said that adicommodation and other facilities should be provided. Sometimes these tfacilities could be arranged within the newly established clinic.

The organization should be in a close contact with the local authorities and the activities of the NGO has to be supported by these authorities. The local authoritie's should be motivated for mutual assistance for the services provided for them.

Some NGOs pay the salary of their field staff from the money received for service charge or med cine they sold because transferring this money back to Pesh fwar is too risky. But GAF said that their staff who work close to the border of Pakistan, those who supply their needs from Pakistani market, do not accept Afghanis, especially the small notes, which would be changed for less than the actual exchange rate. 


\section{1}

III. Result of the negotiation between GAF and ARC:

In the previous meeting of the veterinary coordination it was finalized that letters should be send to UNDP and German Government to support their funding for the risting situation in two districts of Logar province, but later Gar disagreed and opposed sending letter to German Government. The issue was discussed in the meeting and it was deriderl that letters should be sent to concerned NGOs and lJNDr. Then it's up to GAF whether to inform the German goveranmsil or not:

I.V. COMDEV's policy for charge on medicines:

COMDEV has formulated a policy of charging for both services and medicine. COMDEV explained the details of theil proposel. Very simply the charges will pay the waghe of village workers and location allowances of veterinary 5 lalf.

i) Vaccination: The charge is Afs. $15 / 5 h e p$ or gont all nf which nfs. 10 will go lio vi.l lage woyker. s will got th paravet and nFs. '2 will remain for DyM.

i i) Treatment fee: There is a charge of Afs. 20/grat 8 . sheep and Afs. $40 / c a t t l e$ \& horse.

i i i) Charge for medicine: All medjcjnes from COMUEV is sold for 60\% directly to the animal owners. If the lirajumil village workers want: to sell merlicille, they ran luy il for $45 \%$ which again they can se 11 i.t for $60 \%$.

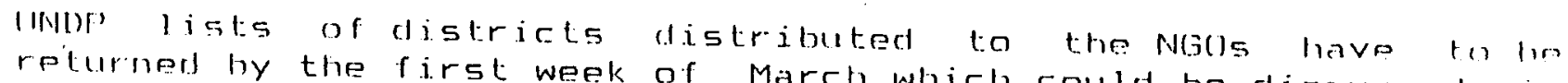
llir? heyt meeting first week of March which rould be discussnol in 


\section{2 \\ $A C B A R$ \\ VETER INARY COORD INAT ION}

Minutes of the meeting held

on. Tuesday, March 12, 1991 in ACBAR

Attendants:

A

Neil Chesterton (chairman)

M. Zaher Anwary

COMDEV

RONCO

DCA

UNDP

ARC

GAF

MADERA

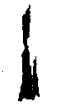

Erik Jacolos

DCA

Bert Bosch

DA I

Dr. Mehraban

UNDP

Dr. Sayed Mohammad

GAF

Dr. Baker

Sarah Gray

UNDP

ARC

ACBAR

I. Announcements:

a. Mr.baker of UNDP who is on a monitoring inission to review UNDP projects attended the meeting and different NGOs briefed hin about their on-going programs.

b. DCA asked if there is any information about diseases in Takhar and Badghis. Dr. Daud Shah of GAF promised to provide some information.

c. DAI has the intention of sending chickens to Logar and randahar if other NGOs don't have similar program.

II. Discussion on the location of NGOs activities for 1991:

UNDP has distributed a form that NGOs should show the location of their activities. The form was to be returned before the March 12 meeting but some NGOs haven't returned them yet. Therefore, the issue will be discussed in the next coordination meeting.

III. Discussion over unsold medicine from last year:

Sometimes the medicine of a project remains unused. Since the NGOs have to clear their financial status at the end of each year,. they can transfer the unsold medicine to the next. year projects. NGOs should be accountable to UNDF in Pakistani Rupees.

IV. Quality control of instruments:

It was said that some Pakistani made instruments are not of

- good quality. The Paksmith company, Sialkot, produces good instruments, if available. Some good quality instruments (Bordizzos) have been purchased from Kabul. 


\section{3}

Pintion: Some agencies have been sent different quality distruments lo what they ardered:

MADERA has received somel vaccine for Agalactia from Turkey: If information. are intefested, they can contact MADERA for INDP has received some Anthrax vaccine. The expire date is the lusting it in Peshawar. 
$A C B A B$

\section{VETER INARY COORDINAT ION}

Minutes of the meeting held

on Tuesday, March 26, 1991, in ACBAR

\section{Attendants:}

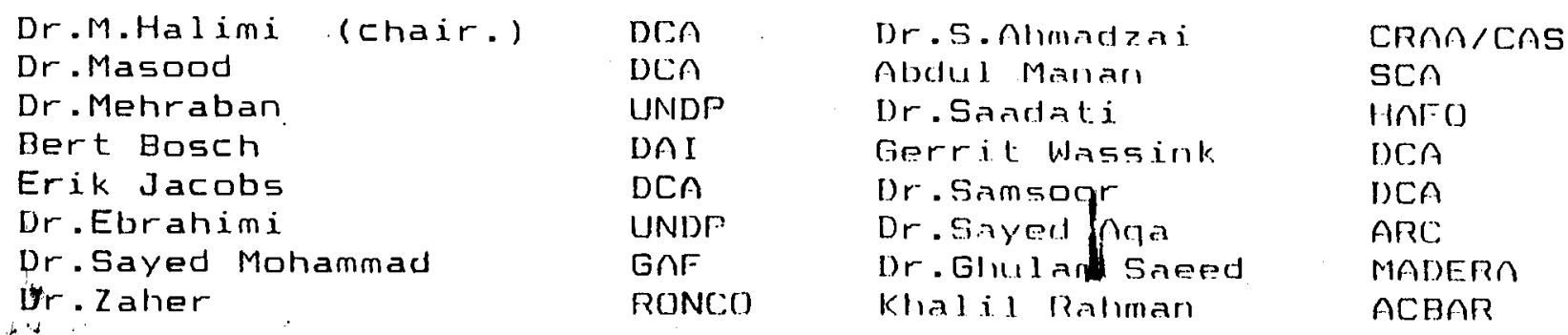

I. Announcements:

Dr.Samsoor of DCA had interviewed about 100 animal owners. Majority of these animal owners were not happy ahout the condition of their animals. DCn had prepared 15 different charts of animals which were sluwn in the meeting. lhe charts were explaining how the animals get diseased and how can be treated and ue mrevented. Din will hang the charts in the centers of their rielil linits and also will be prepared as small pamplilets for distribution to the farmers. Some charts were provided by nlRe showing how to prepare sil age.

Some good comments were made for lietter dovelopment of these kinds of charts.

I I Poultry programs inside nfghanistan :

DAI has the intention of sending rlickons into nfghanistan. In he previous veterinary meeting lnt asked other NGOs about their similar programs. onl is a commercial hased organization. It is offering aririculiural services for subsidized prices.

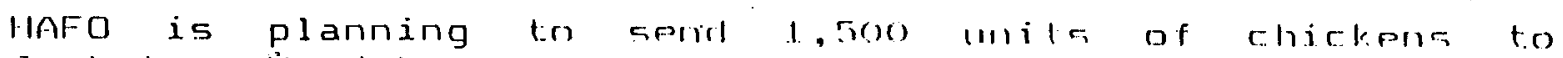
Jaghatoo, Wardak. Tle clickens will ho of two months and will be provided by IJNDP.

DAI wanted to take some chickens lo khogiani district of Nangarhar province last year but the condition was not good and then they were taken lo Chaparhar district of the same - province. The chickens were placell in wouden cages and then transported by pick ups. There was no great lose ar only about 1\%. It took only a clay lo shift the chickens from Pendi to Chaparhar. They distrimuted ?,000 for nfa.350 each. DAI is going to start similar proçrams in kandahar, Zabul and Logar provinces in 2 montlis. 


\section{5}

DAI is interested to be in contact with other NGOs regarding the vaccination of their chickens.

Lajnat All Birr has a poultry project in Kunar. The project has an incubator to hatch eggs but due to lack of proper measures they could not get a good result from this incubator.

ISRA wants to have poultry distrimution program in roat, Nangarhar.

III. NGOs location of activities for 1991:

UNDP had distributed some forms. lo the NGOs involved in veterinary activities. The NGUs wore asked to show the location of their activilies for better planming of new projects. These forms were r.jllad out by NGOs and were sent to UNDP. The integrated form was redistributed to the members before the meeting and was liscussed in the mpeting. DAI and COMDEV were not included in the integrated form.

\section{Letter to GAF and ARC:}

Since the letter was from Mr. Neil Cheaterton, the chailman, who was not present in life meeting, lile issue was postuoned to the next agenda.

Presentation about demining dous by runco:

RONCO/AID has received 19 doys from ij.5. A. and Thailand. These dogs have been trained especially for mine detertion. RONCO also has a team of deminers. Arter the dogs detertipd the mines in the area, they will be exploded by deminprs. The dogs are given specin! foul provideal from thailand.

RONCO has around 50 veterinary starf out of which 5 are veterinary doctors. They gave a sperial 5 weeks training about dogs to their palavets. llir veterinary stafr have also been taking care or the 2,000 mules distributed to Mujahedin by this agency.

VI. Centralization medicines/equipinets: of In the previous coordination meeting DAI proposed to centralize the purchase of veterinary medicines/equipmonts. This will save the time of many MGOs and will calso to purchase the good cjuality medicine/rquipments in a cheaper rate. DAI can help this but doesn't want to work as a mediator.

DCA said that it was asked by some cither NGOs for providing medicine, so DCA is studying the case.

UNDP: which has been providing fund for veterinary project supplies is planning if possible to directly provide the needs of the NGOs instead of giving them money. Hecause supply of veterinary medicinelpquipments and medi.rines especially from outside Pakistan is easifer for UNDP than the
NGOs. 


\section{$A \_C \_B \_A \_R$ \\ YETERINARY COORD.LNA'TIOH \\ Minutes of the meeting held \\ on Tuesday, April 9, 1991 in $\triangle C B A R$}

\section{Attendants:}

Dr.lla.limi (chair.)

Dr.Hehraban

Semaneh Tamrat

Dur Mohammad

Bert Bosch

Abdul Manan

Dr.M.Halimj.

Khal il Ruhman

\begin{tabular}{|c|c|c|}
\hline $\mathrm{DC} \Lambda$ & Dr. (ilullom Sreed & MADERA \\
\hline UNDP & Dr. Finnhimi & UNDP \\
\hline UNOCA & Dr. Sayod llolinmmad & $G \wedge F$ \\
\hline$\triangle \mathrm{RC}$ & Dr.zrlier & GAF \\
\hline DAI & Erik lacohts & $\mathrm{DCA}$ \\
\hline$S C A$ & D). Sonnars & $\mathrm{DC} \Lambda$ \\
\hline LCA & D) S Sayerl $\Lambda r_{1}$ a & ARC \\
\hline
\end{tabular}

I. Announcements:

a. In the minutes of the Veterinary Coordination of March 26 , in the second ilen of the agemra, paragraph one was: corrected to the following rorm: "DAI is main]y offering agricultural servires for subsidized prices: and is developing. a small animal luspliandry program."

b. In the meeting of Mrroh 20 , Mastated that it wi]। supply medicines for HGOs rrovirforl the order ho received at least comple nif norlict ago. It's njen important that the ardor should he rin the basis of all standard kits. Primarily life miln mas to charge $2 \%$ on the NGOs, but thjs will he rompalunted and will ho announcerl.

It was, agreed that there has ln lies standard list of medicines and the mrolicines nilronl hy $\mathrm{NGOS}$ should hr. selected from that list.

c. Lajnat Al-Birr Al-lslamia line recided to starl veterinary activities. The Curminalian proposed lhal

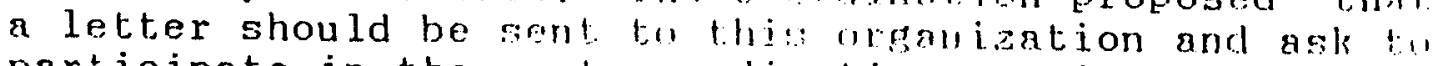
participate in the nox monrlination meeting.

II. NGOS estimation about thejr need for Anthelmentias and Ectoparasiticides:

Only DCA and GAF had estimitiel their lloral as follows:

DCA

Anthelmentics.

340, 1und hoses

1, 8u!n, rulu doses; for cattio

for sheep

GAF's demand for the first, 6 month: of 1991 will continus: the same as last year, but. jl. might. lim. Irmble for the last fo months. The following is the estinntion for 1991.

Anthelmentics. for shents

for ratite

1.,200,000 doz 60,000 doz 


\section{7}

Other NGOs were also requested to provirle their estimaterl needs.

The Anthelmentics is rommouly available in powdes formulation instead of liquirl form anrl lhe farmers are much familiar with its ligujul formulation. UNDP advised thal. changing from liquid to powcler slimulrl be carried out. gradually .

II Yaccination (Enteretoxemia) campaign of different NGOs for. 1991:

- UNDP will be budgeting for lihe sirrely or medicines, and il. wanted to know about lihe rexirinre and cases of Enterotoxemia in different mrts of Afghrnistan. Since the roads to Afghanistan ner rolused, froll lline reported gbout Lhr. Fnterotoxemia case. GAl irmeled mons in Vangarhar, Jogar and Bamyan. MADERA refoulmol a mo from Kunar which was tested by its laboratory : :lal innerl in Kunar.

It is important to difformlitalo linloroloxemia from other

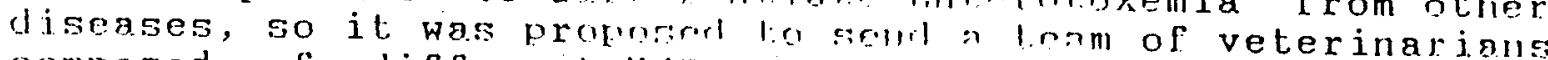
composed of different. llios: to llis nira as soon as the

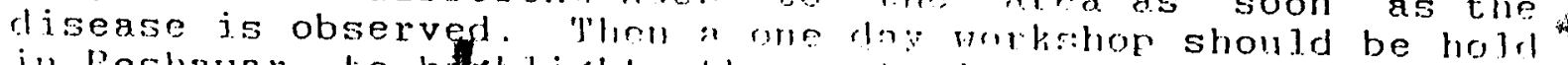

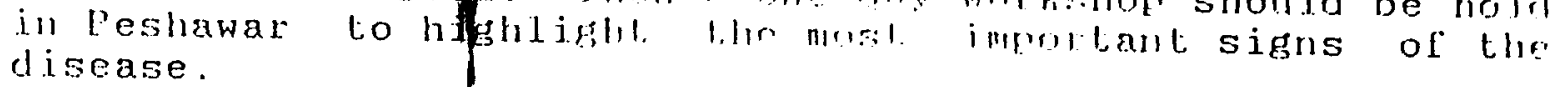

IV. Letter to_ARC and GAF:

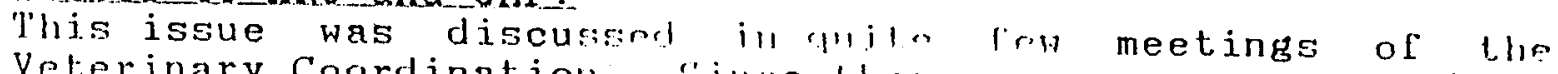
Veterinary Coordination. Simre lifrer las no agreement about.

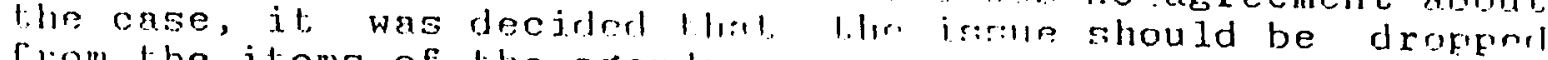
from the items of the agrorln. 


\section{8 \\ \begin{tabular}{lllll}
$\dot{A}$ & $C$ & $\mathrm{~B}$ & $\mathrm{~A}$ & $\mathrm{R}$ \\
\hline
\end{tabular} \\ VETER INARY COORDINATION}

Minutes of the meeting held on Tuesday. April 23 in ACMn?

Attendants:

Neil Chesterton (chairman)

COMDEV
CRAA/CAS
UNDP
GAF
DCA
SCO

Dr. Daud Shah

Sinf

Dr.Mehrabar

(IN)

Dr.Sanaulhaq

Dr. Halimi

D)CA

Dr. Sayed Mohammad

Erik Jacobs

DCA

Dr.Samsore

Gerrit Wassink

DCA

Laj.Al-B. Khalil Raluman

nRr:

riciBAR

Mold .Mustafa Mohammad

Dr. Syed Aqa

I. Announcementsi:

a. In the minutes of the previous meeting in page 2 - paragraph 2 , the word observed should he corrected to reported.

b. In the meeting of April 9, DCA mentioned that the charge of $2 \%$ on providing medicine for NGOs will be reevalualed, lihich was increased to $3 \%$.

c. A veterinary clinic in Nasir Bagh formerly operated by LINHCI? is now with DCA. It will be used mainly for training purposes. Individuals and groups can go there with an parly appointment. Service won't be charged but medicine will be charged for $50 \%$.

11. More reports about Enterotuxemia:

There are doubts about the presence of Enterotoxemia in Arghanistan, and it's difficult to differentiale il: from other diseases.

DCA field staff reported the disease from inany parti lif Afghanistan. The symptoms were explained the same ls al Enterotoxemia. -- CAS reported that they observerl lihe disease in Vegal, Kunar last year. - COMDEV said that lilo high mortality rate was reported in spring and winter in Balkh province.

GAF. stated that their field workers from more than $A$ different districts will be coming in May-June. A seminar on Enterotoxemia and post mortem diagnostic procedure could be held, If the field personnel of other NGOs are also in Peshawar in the same time. 'The idea was approved. GAF will fix the date of this seminar in the coming conrdination meeting and Dr.Mnhebullall Halimi (DCn) was assigned ton give presentation.

111. Quantity of the Enterotoxemia vaceine sent lo the area ginco last year:

DCn got its vaccine from Qurella which is a littlentighr in rate (50 dozes Rs.40) than Lahore but the quality was better. If NGOs gret there vaceine from Quetta (lifl) will tiry 


\section{9}

to compensate the extra money. Transportation should be done by air.

- DCA has sent 90,000 dozes.

- GAF has sent 250,000 dozes.

- CAS has sent 62,000 dazes from last October. From that amount 38179 dozes has been used (in Kunar).

- ARC has supplied 150,000 clozes of vaccine recently. Sincm the season is over vaccination could not be done. The delay was due to poor supply system in ARC.

CRAA/CAS has close relations with one of the suppliers of the vaccine and can supply it with the market rate.

IV. In the last coordination meeting it was mentioned that: Lajnat Al-Birr Al-Islamia has started some veterinary activities and it was suggested that their representative should be invited to the Coordination meeting to give information about there programs. Mr.Mohammad Mustala, the representative of the organization took part in the mreting. He showed the Jwillingmess of the organization, for coordination and participation in regular velierinary meetings. He said that the responsible person for veterinary section will participate in the next coordinatinn meeting and will talk about the program.

V. GAF instructors with the courage of UNDP has provided a draft of a teaching manual for basic veterinary workers (BVW). Copies of the draft will be sent to some concerned NGOs for more comments and then as avtext vill he distributed to other NGOs involved in veterinary activitips. ty

There are some paravets, trained by different programs, Jumim for jub. If NGOs can use them in there programs. 


\section{0}

\section{A C $\mathrm{B} A \mathrm{R}$ AGRICULTURE SUB-COMMITTEE}

Minutes of the meeting held on Tuesday, May, 7, 1991 in, ACBNR

Attendants:

$\begin{array}{llll}\text { Dr.M.Halimi (chairman) } & \text { DCA } & \text { Dr.Mohammad Zaher } & \text { RONCO/NIF } \\ \text { Dr.Ghulam Saeed } & \text { MADERA } & \text { Dr.Sadati } & \text { HAFO } \\ \text { Dr.Zaker } & \text { GAF } & \text { Dr.G.Wassink } & \text { DCA } \\ \text { Dr.Sayed Mohammad } & \text { GAF } & \text { Dr.Erik Jacobs } & \text { DCA } \\ \text { Dr.Hamdi } & \text { Laj.Al-B. Dr.Bram Schreuder } & \text { DCA } \\ \text { Dr.S.Ahmadzai } & \text { CRAA } & \text { Mohd Mustafa Mohd } & \text { Laj.nI-B. } \\ \text { Khalil Rahman } & \text { ACBAR } & & \end{array}$

I. Lajant Al-Airr Al-Islamiah presentation atout their veterianry prourammes:

This organization has . recently started some velerinary programmes. Dr.Handi Al Morsy and Mohd Mustafa Mohd tonk part in the meeting and explained their programine as follows:

At present, the organization has 3 poultry programines sioh in Chaghasrai of Kunar province, Khogiani (Toto) and Shinwar (Ghani Khail) of Nangar province and in Chamkani (Shari Na(n) of Paktia province. All 3 projects contained about 10,000 chickens out of which the 3,000 in Kunar were killed hy the last scud attack on kunar capitol city. A hatching machine was also completely destroyed during the attack. This project will be reestablished very soon. Lajnat nl-Birr is going to extend veterinary services beside the poultry farm in Ghani Khail.

Both curative and prophylactic veterinary services will he working in Kunar and Nangarhar. Lajnat Al-Birr's veterinary staff is trained by DCA. Dr.Hamdi said that thoir. programmes will cover the areas untouched by other organizations.

II. Reports about animal disenses from field:

GAF received reports about Enterotoxemin from Lilporir, Nangarhar province, and sent two veterinarians to mbserve the area. The veterinarians found that the disense was Black Quarter. Some medicine was also sent for the later disease. According to GAF the same disease was mhaprved in Momandara, Daka and Shalman.

DCA field staff have reproted different diseases in the following areas: (The report is based on sympoms.)

- Anthrax in Helmand, Ghazni, and Wardak.

- Hemor. Septicapmia in Bamyan, Ghazni and Wardar.

- Black Quarter in Bamyan and Helmand.

- High cases of Enterotoxemia in Ghazhi and Helmand. 
- Contagious Caprine in Nangarhar and Paktika.

- Enterotoxepia in Ghazni and Helmand.

- FMD in Ghafni and Helmand.

- Sheep Pox in Ghazni Nangarhar and Paktika.

HAFO has received reports about the existence of black Quarter, Blackleg, Anthrax, Hemorrhagic Septicaemia and Foot and Mouth diseases in Jaghato, Wardak. The reports show 5-6 months back.

Dr.Bram Schreuder of DCA said that the cerologic tests of some confusing diseases could be done through DCA, in which the samples will be sent to Netherlands.

The AGENDA

for the next meeting which will be held at $8: 15$, Tuesday, May 21, 1991 in ACBAR

is

I. Announcements

II. FAO's report UNDP

III. Reports about animal diseases from Afghanistan

IV. Coordination of cold chain facilities

V. Transportation cost of commodities to Afghanistan -DCA

VI. Vaccine supply -MADERA 


\section{$\triangle S B \quad B \quad R$ \\ VEIRERTANRY SOORDCNATTON \\ Minuters of the meetiou held ou Tuesdny. May 21 in $\wedge$ cruR}

\section{Attendauts:}

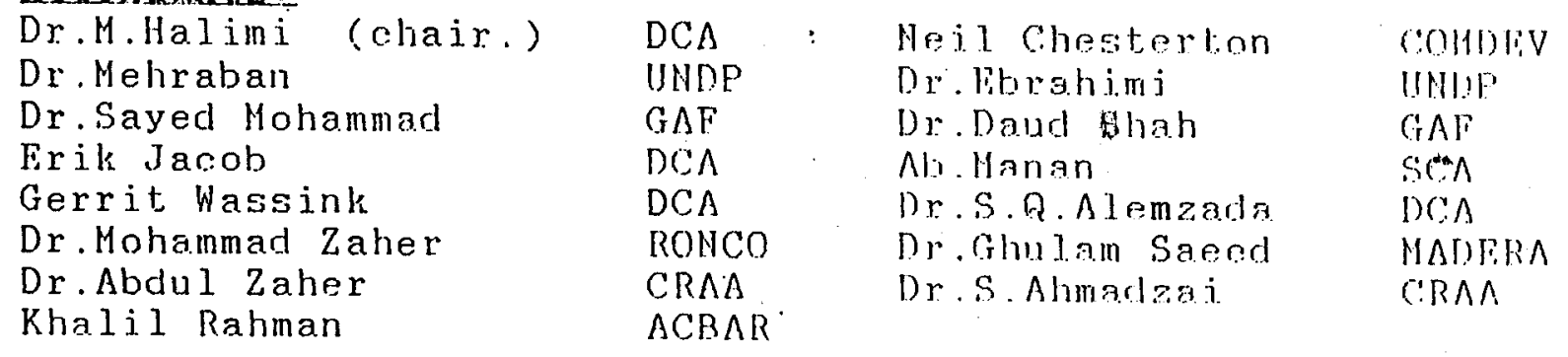

J. Aunouncsments:

MADERA is going to extenrl its propirams and provide viral vaccines.

I.I. Report about FAO:

UHDP was asked by Kabul office lalt year to submit a proposal for Northern and Western provinces of $\Lambda$ fghnnistan. A sum of US $\$ 6,000,000$ was alloraterl for this murpos. 'llte strategy was questionable whether it will work ril not. But. now this project has been hander over to ThO Kabul. The project has hired a veterinarian from Belgium. He will slso establish a center in Kandahar and will revise the proposal. He also has the intention of visiting und Pakistan (Peshawar).

The program will start from Hazar-i-Sharif. 2 III veterinarians will be hired and they will train basice vel. workers (BVW). These BVWs will be supplied witl mrolioine. UNDP is still in doubt whether the project will work or not: The second part of the proposal is to equip the existing government veterinary centers. The ruoject will also provide cold storage in different parts of the country to make vaccines available.

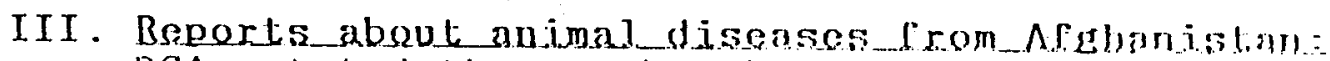

DCA stated the outbreak of Blackleg in criws in lalros, Haidan. According to DCA about 30 cases were observed and a lot, of animals died. Trentment has ben sitalent.

MADERA reported the following cases in kurar liagnosed by clinical symptoms:

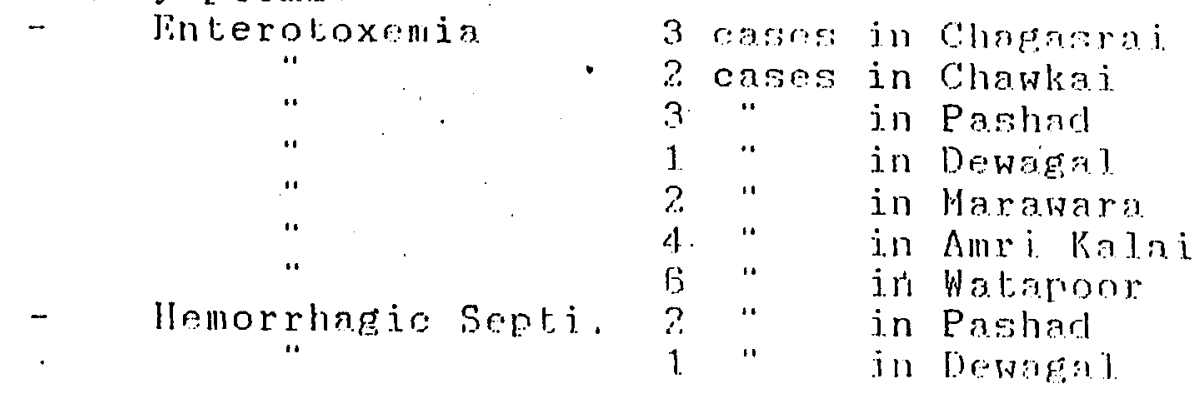


GAF has received non-confirmed reports about cases of Enterotoxemia from Pacheer and Magam, Nangarhar provinge.

The general opinion of the coordination committee and the donors was/is to do not rely on clinjcal symptons only. There has to be post mortem follow up. It was omplasidacer that the diagnostic procodure of some diseases should hro done in labs other than ia Pakistan.

DCA proposed that they will prepare ljot of latoratrity procedures of some major animal djseases, which bill l." submitted to the next coordination meeting for discoussim.

A one-clay seminar will be held to discuss the poot morlath procedure of diagnosing a disease. GAF wjlJ bring nne of its lab technicians to this mesting. The date for the seminar will be fixed in the next vet coordination Herling.

IV. Coordination of shajn seold Fincidjitises:

Some of the organjzations such as IRC, $\triangle V I C S N$, HCA, Lijmat. Al-Birr Al-Islamia and... has cold chain facilitifes for: human vaccines. If they could be contacted to provirle facilities for animal. vaccine too or at least to see their. cold chain systems. "ARC's cold chains could be userl sup. animal vaccines. $\Lambda$ memo should be oirculaterl from $\Lambda C B \wedge R$ in ask NGOs if they can facilitate ice box systin.

V. Transportetion sast of commojites lo Afshanislian:

It was said that it's difficult to find a fixed ratee ror the transportation of the commodities into and staff movement within Afghanistan. This puoblem could be solverl consulting the NGOs working in same region. There are some transport agents in Pakistan to be contacted. For examrle some could be contacted in Namak Mandaj.

VI. Yaccjues_supply:

Vaccine supply is a problem for many NGOs. UHDP arilied the NGOs to supply high quality vaccjnes. Vaceineg producferl in Quetta are high qualiby. lhey are a lijtile expensive though. MCI quetta can facilitate supplying vacoines. DCA said vaccines could be purchased from VRI Quella rirrolly. The order should be at least a month in advance and the money should be paid in advance too. GAF got some vacrines: from Lahore but not good quality. MADERA got a list of the different types of vaccines from lahore. The following is the rate of these vaccines:

\begin{tabular}{|c|c|c|c|}
\hline Hemorrhagic Septicaemia & 60 dozes & Rs & 62.20 \\
\hline B1ackleg & 60 &. & 62.20 \\
\hline Anthrax & 600 & 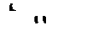 & 301 \\
\hline Enterotoxemia & 100 & " & 50 \\
\hline Foot and Mouth disease & 60 & " & $3 \cap 2$ \\
\hline
\end{tabular}



UNDP visited DCA and GAF s clinics in Qsrabagh, Ghazni and Jaji,
Paktia. The buildings for both cljoics are poorly managerl.
team of UNDP will be coming from New York to clinics clinics in a better place. 
195

i

i 


\section{A C B A R \\ VETER INARY COORDINATION}

Minutes of the meetings held on Tuesday. May 29 in ACBAR

\section{Attendants:}

\begin{tabular}{llll}
\hline Neil Chesterton (chair.) & COMDEV & Abdurrab & DCA \\
Nasrullah & MADERA & Ghulam Saeed & MADERA \\
Mohebullah Halimi & DCA & Dr.Mohd.Sadiq & MADERA \\
Dr.H.Al Morsy & L.B. I & M.M.Moustafa & L.B. I \\
Dr.Azizullah & GAF & Gerrit Wosink & DCA \\
Erik Jacobs & DCA & Abdul Mafan & SCA \\
Noor Hadi & GAF & Sanaul HIl Ahmadzai CRAA \\
Sayed Mohammad & GAF & Mehraban & UNDP \\
Zaker & GAF & Daud Shah & GAF \\
Din Mohammad & GAF & Hedwig Schlags & GAF \\
Sediqullah & CRAA & M.Rahim & DCA \\
Khalil Rahman & ACBAR & &
\end{tabular}

I. Announcements:

A form showing how to report disease outbreak which has been prepared by UNDP was distributed to members. Member NGDs were requested express their opinion about this form.

II. Presentations by the field staff of different NGOs:

Field veterinarians of GAF, MADERA and DCA and a 1 ab technician of GAF participated in the meeting and explained their procedures to diagnosing different kinds of animal diseases under field conditions. Field staff of GAF and MADERA described their observations as follows:

Dr.Din Mohammad - GAF:

Dr.Din Mohd who has been working in Charkh, Logar province said that Anthrax could be found in acute, sub-acute and peracute forms. It is difficult to see the clinical symptoms in living animals. Blood comes fröm all natural openings of the animal. The spleen enlarges. The animal has constipation. Later, it goes to diarrhoea which causes to the death of the animal. Dr.Din Mohd has prepared a slide from the liver which was fixed with color. A sample of this slide has also sent to Peshawar. When he was asked why carcass was post mortemed where Anthrax was suspected. $\mathrm{He}$ said because people killed animals when sick before they died.

A case of Blackleg was observed. The animal had ... The disease infected area of the animal was swollen. The medicine given to the animal did not save the animal. It was slaughtered the coming night. The muscles of the infected area were dark. Secretions with bad smell containing air babbles was coming from the muscles.

Cases of Enterotoxemia were seen in the area. The disease is more common in the spring time and seen primarily in new 
born sheep (lambs). Around 30 to 50 animals were last by the disease. The animal gets diarrhoea and shows craziness. The anımal was bleeding and even urine was mixed with blood. A yellowish fluid was seen in the precordium cavity. The disease was not seen in the areas vaccinated.

Dr.Azizullah - GAF:

Dr.Azizullah who has been working in Bamyan has seen the Enterotoxemia type- in the area. He also stated that the disease is more common in new born sheep (lambs). Lambs are seen uncomfortable and lying down on the ground. The following symptoms were seen in the dead animals:

a. the intestines are usually swollen and ........

b. Necrose and ulceration apenings are surrounded by red color hyperacmi.

c. Water collection was seen in precordium.

d. Yellowish water collection was seen in chest cavity.

e. Intestines were gaseous.

f. Intestines were red color and haemorrgi.

g. The disease was observed in March.

h. The pasture was newly growing.

Dr. Noorul Hadi - GAF:

Dr.Noorul Hadi who has been working in Panjsher area, reported about the presence of FMD in the area. He said that this disease is occurring in cow, buffalo, sheep, goat and camel. He observed the following symptoms in a cow in Panjsher clinic:

a. The animal had high body temperature.

b. Saliva with scum was coming from the mouth of the animal. Mostly the mouth of the animal was closed.

c. The animal was limping.

d. The legs of the animal were warm and vesicles were visible.

e. The legs were of the animal were felt painful due to palpate.

f. Some burst vesicles were seen on the tongue which were changed to ulcer.

The clinic advised the animal owner to use antiseptic cleaning there animals.

Dr. Mohammad Sadeq - MADERA:

Dr.Sadeq who has been working in Vegal Valley reported that - Enterotoxemia is seen in that valley. People of the valley use different local names for different types of diseases. For example; lamb dysentray is a common type occurs in lambs. This disease is locally called "Zoorshta Dook", which means milk disease. The lambs use more milk get diarrhoea. Dr.Sadeq said that he has seen the lambs died their stamachs full of spoiled milk. The intestines were swollen and the animal was seen thin losing its water before dead. A kid was lying down on the ground and scum was 
coming from its mouth. The mouth of the animal was cool and died after 24 hours. If the animals are not treated urgently there is $70 \%$ lose.

FMD is called "Krola". in Vegal. Dr.Sadeq has seen this disease in cows, calves, goats and sheep in Nesha Gram of Vegal Valley. In cows: and calves ulcers are existing in mouth and legs of the animal and saliva is coming from the mouth of the animal. Sometimes the animal can not eat. The animal is thin and milk production is low and sometimes ceases.

Blood was taken from the animal. Serum was isolated and phenol $5 \%$ was added to the 9 amount of serum. The sample was sent to DCA in icebox. The result was type $A-0$.

\section{Mr. Nasrullah - MADERA:}

Mr.Nasrullah who has been working with MADERA is one of the well experienced lab technicians. He has worked for the ministry of Agriculture for a long period of time. Nasrullah stated his field microscopic examinations as foll ows:

a. Enterotoxemia: Infected parts of the intestine, liver and spleen of the dead animals from Kunar has come many times. Mr.Nasrullah said that he has prepared 51 ides from the materials inside the intestine and the stool taken from the intestine. He has stained the slides. He stated based on the experience, type of the enterotoxemia could be recognized. Diagnosing the disease according to the toxin is difficult under the field conditions in Afghanistan and even in Pakistan.

b. Blackleg: Nasrullah observed a calf in Chauki district. The thigh and back of the animal had been damaged. The temperature of the animal was high and it was limping. The animal had been slaughtered by the time antibiotic was received from the clinic. Some meat (turned black) was taken from the leg and back of the slaughtered animal. It was taken to the lab. The top part of the meat was burnt with light flame. - A sample was taken from that with a sterilized loop and slide was fixed. The slide was stained, and cl. Chauvi was diagnosed. The result was reported to the related clinic.

c. FMD: Nasrullah said that he has observed 3 different types of FMD in Jalalabad which are Asia-1, A22 and 096. The type Asia-l outbreaks in winter. The tongue of the animal was infected with the disease. The types $A, D$ and $D-I$ are observed in summer.

A seminar should be held to explain the followings:

a. Post mortem techniques

b. How should the samples be taken. 


\section{9}

c. What samples could practically be taken?

The seminar will be held in GAF Veterinary Training Center. committee composed of Dr.Halimi (DCA) and Dr.zaker (GAF) will work on the contents and date of the seminar.

A French company who's members visited UNDP Peshawar said that FDM type 0 is common in Pakistan. They provide for this type of disease for Pakistan. The company will help diagnosing samples of the NGOs freely. DCA and GAF have the address of the company. 
$A C B A R$

VETERINARY COORDINATION

Minutes of the meeting held on Tuesday. June 4, in ACBAR

Attendants:

\begin{tabular}{llll}
\hline Dr.M.Halimi (chair.) & DCA & Dr.Mehraban & UNDP \\
Abdul Manan & SCA & Nancy Hatch Dupree ACBAR \\
Erik Jacobs & DCA & Sadiqullah & CRAA \\
Sayed Mohammad & GAF & Sanaul Haq Ahmadzai CRAA \\
Zaker & GAF & Dr.Zaher Anwari & RONCO/AID \\
Dr.Ghulam Saejed & MADERA & Mohd Mustafa Mohd & L. B. I. \\
Khalil Rahman & ACBAR & &
\end{tabular}

I. Discussion over the proposed seminar:

In the previous coordination meeting it was suggested to hold a seminar for field staff of the NGOs to describe how and what samples to be taken from animal infected by a disease. GAF and DCA contacted Veterinary Research Institute (VRI) Peshawar to facilitate some practical requirements for Afghan veterinarians. VRI Peshawar offered that they can train NGOs field staff at this institute. The Coordination members decided to hold a one week training course at VRI. GAF has already sent some of their training staff to be trained there. The course will start Sunday morning, June 8. A translator (English to Pushtu/Dari) will be needed. The Coordination group also discussed what subjects should be taught to the trainees. It was decided that the following subjects should be included in the training program:

- Blood smear and microscopic examination.

- Parasite detection in internal organs.

- If possible vaccine quality control.

- Postmortem technique and samples taking.

- Diseases of poultry that could be postmortenf examination.

involved NGOs were asked to send names of their trainees to Dr.Halimi by Wednesday, June 5 .

II - Animal disease outbreak report:

A report form prepared by UNDP was distributed in the previous coordination meeting and NGOs were asked to express their opinions for any kinds of modifications in the form. Some changes were made as follows:

a. No. of animals died in a flock.

b. Type of animal

c. Age of animal

The final copy of this form will be sent to all member NGOs. NGOs will be asked to report quarterly.

MADERA had observed FMD in Wegal. The samples were sent to Holand which was diagnosed type $A$ and $O$ of this disease. 
201 


\section{ALn $\cap R$ \\ VETERINARY COUIRIINATION}

Minutes of the meeting held on luesday, June 1 n? 1961 in nomrin?

Attenclants:

\begin{tabular}{|c|c|c|c|}
\hline $\begin{array}{l}\text { Dr.Neil C. (cilairman) } \\
\text { Gerrit Wassint. } \\
\text { Dr.Zaker } \\
\text { Dr.Sayed Aqa } \\
\text { Dr.S.Qasem Alemzada }\end{array}$ & $\begin{array}{l}\text { COMDEY } \\
\text { DCA } \\
\text { GAF } \\
\text { ARC: } \\
\text { DCA }\end{array}$ & $\begin{array}{l}\text { Dr.M.Hal ini } \\
\text { Dr. Sayed Mohammad } \\
\text { Dr.M. Taher Mnwal"y } \\
\text { Mohd. Mustafa Mohd. } \\
\text { Khalit Rahman }\end{array}$ & 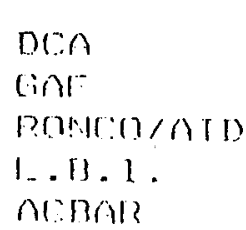 \\
\hline
\end{tabular}

I. Announcement:s:

Dr.Neil, the chairman, apologized failing to
participate in the jast Veterinary corronalion

b. A one-week course was held for high level trannical staff of the NGOs involved in veterinary services at. Veterinary Research Instilute (VRl) Heshawar in the week of June 6 . The participants of the courcie showed their happiness about the contents of thro course and appreciated the efforts of the staff of Whi dial for organizing. the course. They satid a wofol was insufficient for such a course. vel will aive certificates to the atlendants of the rourse.

c. DCA was informed by a farmor in koat area of Rodal district, Nangarhar provinre aboul a catloe discars. The major sign of the disense was lhe presence of bloud

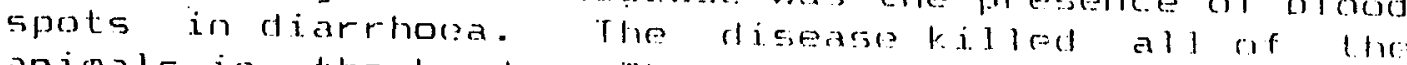
animals in the herd. The same type of diserise wars reported last year but no case was obsarved hy fiella

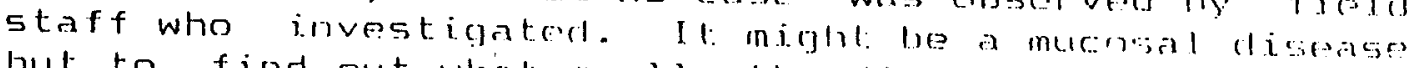
but to find out whal really the disonse is samples af blood, diarrhoed and possibly the lung of the dianaser animal(s) should be taken to the laboralory lob be
tested.

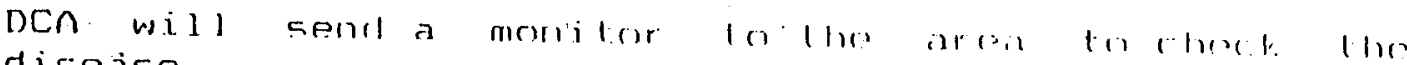
dj. redse.

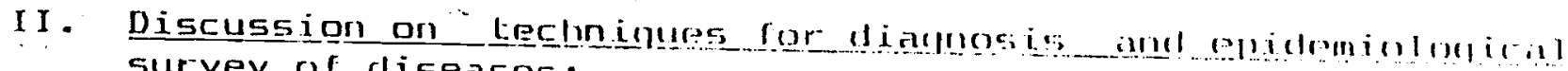
surver of diseases:

n list of the andmal diserse with the laburatory liachosis and epidemiological survey, prepared by don, was presonted to the conrdination meeting. Earh disense was discusapd item by item and some corrections were mate lo lifem.

The issue of recruiting veterinary stinff was discuscifi. All involved agencies agreed to be opened to fach ollor about recruiting new professional staff. This will be done in order to corruption and misuse and at the same time limit opportumilies of 
Recommandations for collection, conservation and transport of FMD lesions

Tongue lesions can cause cliewine mouvements and excess salivation. Foot lesions can cause lameness.

\section{COLLECTION OF SMMPLES}

Tongue lesions are best for liboratory diagnostic. In the absence of tongue leslons, soot lesions will do.

Intact

ler in

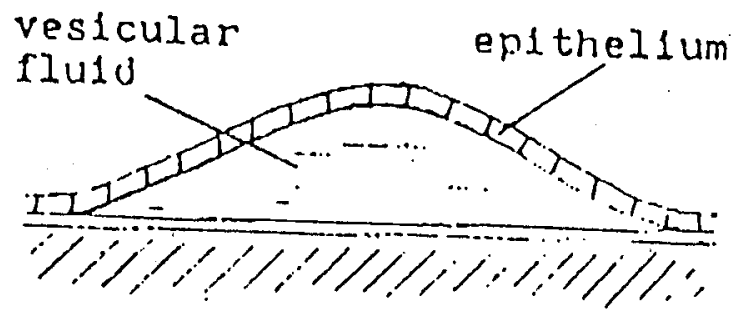

Ruptured lesion

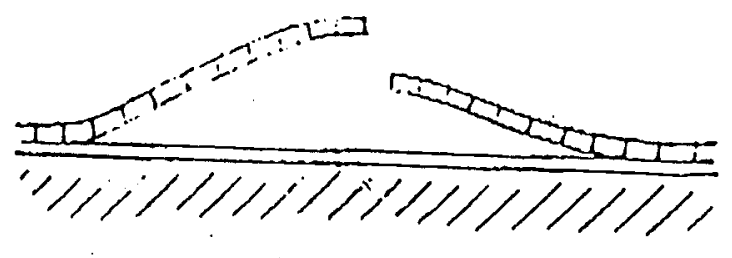

Intact leston (vericle): take as much as possible of the lesion, preferably including the vesicular fluld. Lesions should be taken wlth clean forceps if posslble, otherwise ringers will do. An intact lesion is preferable to a ruptured lesion.

Put the lesion in the flisk containing, the medium and seal.

\section{CONSERVATION}

Samples must be kept in the correct medium (phosphate glycerin buffer):

- The samples may be kept at $4^{\circ} \mathrm{C}$ for a few days ( 3 to 4 ).

- If the samples have to be kept for a longer perlod, they
should be kept at $-20^{\circ} \mathrm{c}$ (deep freezer).

\section{TRAINSPORT}

It is essential that materlals should be in strong and tightly closed containers (In order to avold escape of v1rus). Send materlal in a cool box, preferably with a cold bag, by the quickest method nosslble; not by post. The laboratory must be alerted as to the time of arrival of specimen. RM sunnlies spectal contalners for the purpose of transport: each contalner has a wooden exterior with an aluminlum cylinder inside which holds the sealed flask fliled with phosphate glycerin buffer. 
1! $1 !: 11 ! 1 ?$

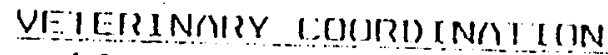

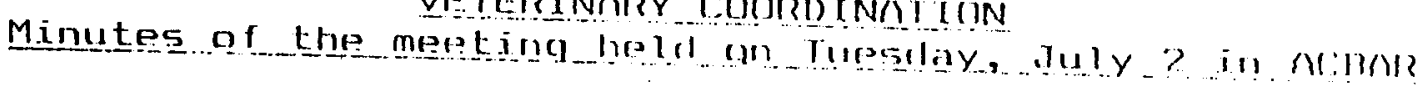

Attendants:

Neil Chesterton (chairman)

Dr. Mohebullah Halimi

Erik Jacolos

COMDEV Dr. WOOOAforal

DCA Aboled Mandan

lim!l!:

Dr. 7aker

Dr. Daud Shah

Din

(inT

Gint

ART:

Dr. Sayed Aqa

Dr.Moh'd Zaher Ariwari

Khalil Rahman

RECHCN)

ACBAIR

(it)

Gererit Warisink dor

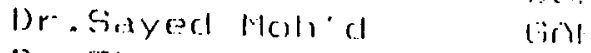

Dr. Ebratiomi

Dur Mohammat

Dr. Secticlul Jah

(II) II)

nili:

conirn

\section{I. nninouncements:}

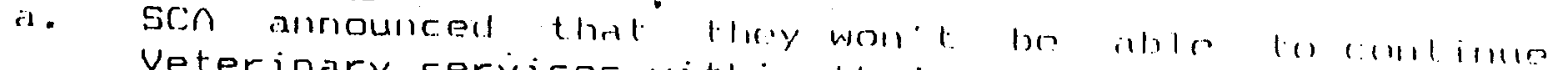
Veterinary services within their progrias after the end of August 1791. Therefore, lhey are lookind for any NGOs who could use their staff and services. holist of staff showing the location is incluted with lige minutes.

b. UNDP has prepared a repor! Disedres Incictent Rropurl: rur distributed los Lhe at lomdiults aheet: lition "nolim:

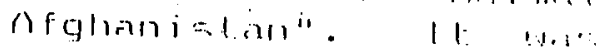

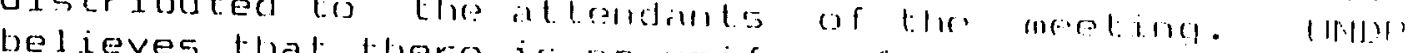
believes that there is no uniform format for these teind of reports received from fllolus. Using a unitorm form will enable lJNDP to prodice a database lo amalyan ror diseases and druggi lised for licem.

c. GAF refresher course started yostarday. July rirsl.

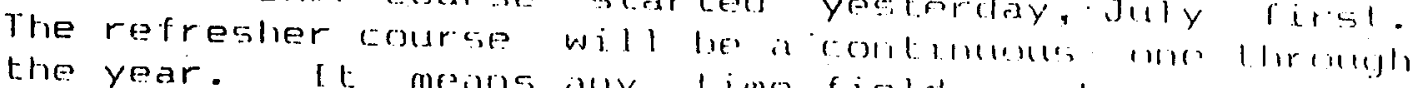

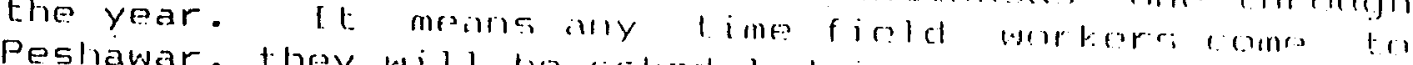

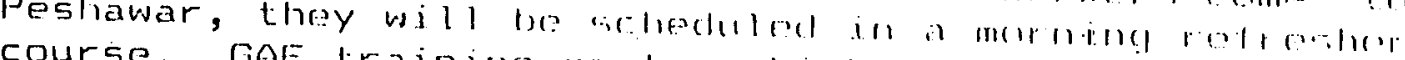
course. GaF training conter which is located in lacho

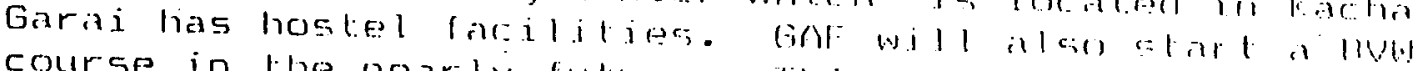

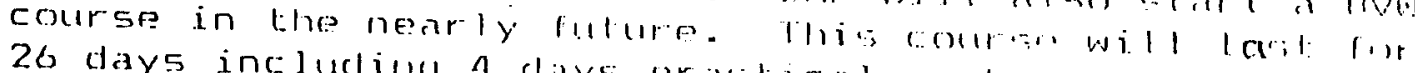
26 days inclucling A cliys furatical worl.

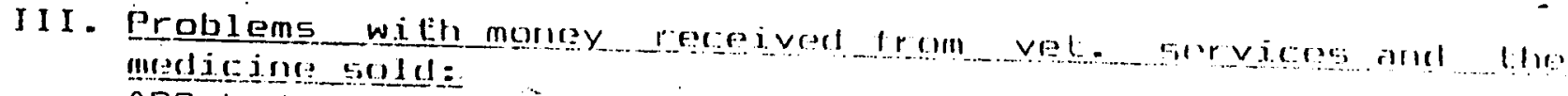

ARE had a tirip of Jaghori and Malistan districtis of bingai

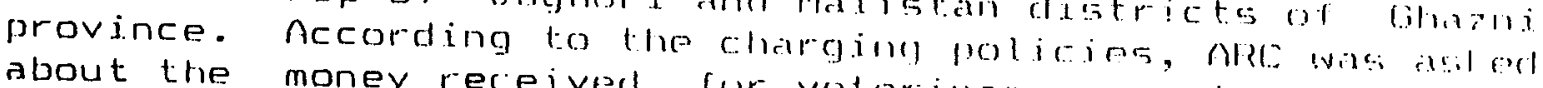
medicine sold. The same might ARC was questioned whore this money goor.

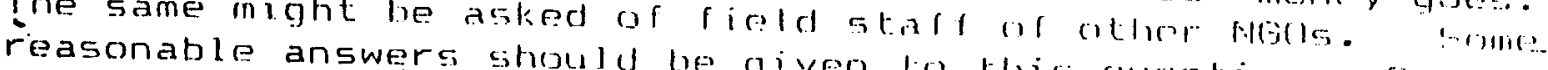

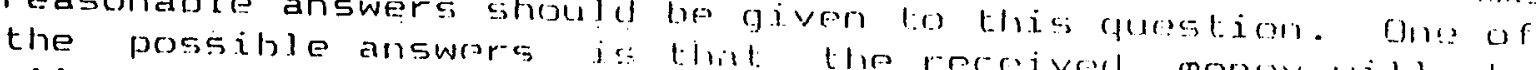

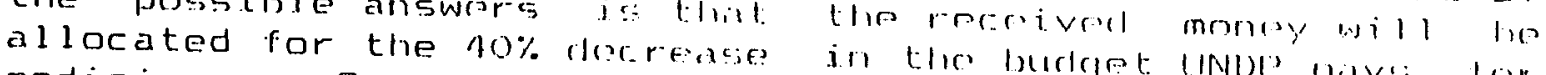

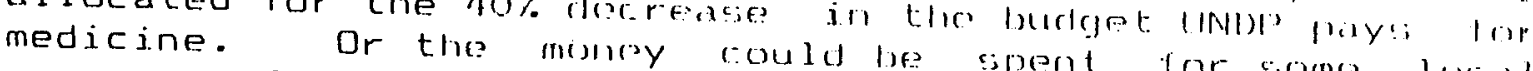

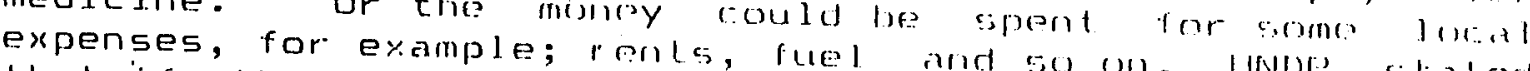

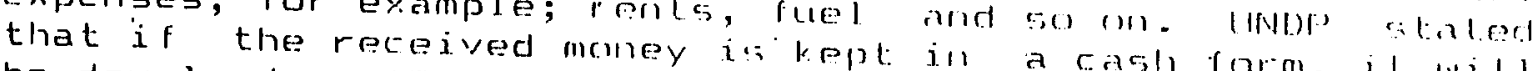
be devalued. nRc: said l.hal 


\section{5}

and medicine should be spent within the project, the same project.

The coordination group asked for a clear policy frum lhe UN side.

IV. Format of the Agenda for Veterinary Courdination:

It was/is the regular agenda for the Veterinary Coordination to talk about diseases. The chairman said that any new ideas will be welcomed to be included in the agenda. The?

followings were said to be discussed in the coming meetings:
- kinds of medicines

- contents of kits

- BVWs training areas

Dr.Gerrit wassink(DCA) was asled to prepare a list of different kinds of drugs and their costs.

GAF has prepared a reference and teaching inanual for trianing BVWs. It has been distributed for correction and comments.

\section{The AGENDR}

for the next meeting which will be held

at $\theta=15$

Tuestax

$\ln 1 \times 17 \times 19 \% 1$

I. Announcements

II. Discussion about Anthelmintics (Dewormers). 
$A[B \cap R$

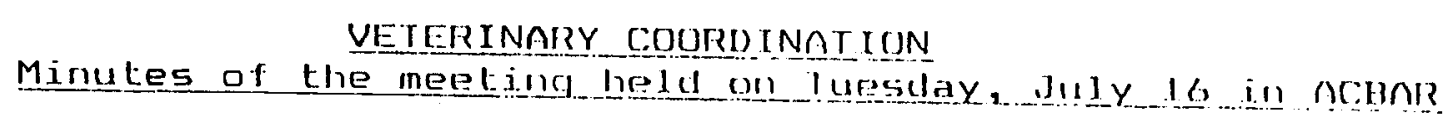

Attendants:

Dr.Neil (chairman)

Dr. Mehraban

Sayed Aqa

Ebrahimi

Nancy Hatch Dupree

Gerrit Wassink

Dr. Ghulam Saeed

Dr. Sadiqullah

Khalil Rahman

\begin{tabular}{|c|c|c|}
\hline COMDEV & Dr. Daud Shah & GAF \\
\hline UNDP & Dr.Zaher & bSONG:4 \\
\hline ARC & Fai. a & Aा?: \\
\hline UNDIP & Sayed Mohammad & riAF: \\
\hline ARIL & Sajd Sultan Masoors & DrA \\
\hline DCA & Dr.M.Hal imi & 1) $\mathrm{C} n$ \\
\hline MADERA & Dr.Aboul zahir & Crenan \\
\hline $\begin{array}{l}\text { CRAA } \\
\text { ACBAR }\end{array}$ & Dr.s.Qusem Alemzada & Dr:A \\
\hline
\end{tabular}

I. Arinouncements:

a. Nancy Hatch Dupree (ARlC) ammounced the work shop for. 2'? .July which will discuss the integration of women component lo all programs. She said that more opportunities should be given to Afghan women to participate in some sectoral works, for example; poultry raising and vacoination that rould be: easily done by women.

b. GAF requested that in the minutes of the last meeting, in item \#I para. Hc 26 days training should he rorrocted ro, in days theoretical and 13 days practical.

II. Discussion on the use of nnthelmentics:

In the last coordination meeting Dr. Wassink was assigned to prepare information about Anthelmentics. This information
paper describing the mechanisms was Anthelmentics and their action which was was distributed to the attendants of the mesting which was discussed in detail. At the end of this paper formula, packing, costs/30kg sheep and costs/150 kg cattle.

The BVWs teaching manual which was prepared by GAF had already been discussed. by GAF and DCA. The matier was once again brought: to the meeting. DCA said that the manual might: be difficult for
BVWs to understand. Finally composed of 5 person (2 finally, it was decided that a gromp should be assigned to re-strurtur 2 from GAF and one from CRAA? group should work full time and finish the work withing said that

The AGENDA for the next coordinalion megting which will be held at $\theta=15$, ruestay, July 30 in nebnr?

1. Announcements.

II. Transport costs, methods, and documents needed including
bikes and motorbikes. 
207 


\section{8}

n.1: II $\cap ! ?$

UETERINARY COMIRIINATION

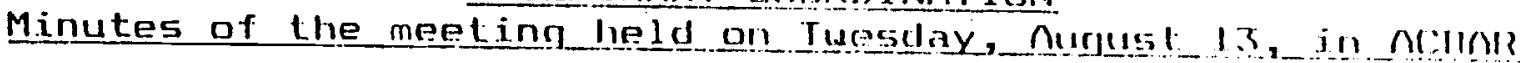

Attendants:

Dr. Neil (Chairman)
Dr.Ghulam Saeed
Ab.Manan
Dr.M.Zaker
Dr. Daud Shah
Dr. Sayed Aqa
Dr.Mehraban

Dr. Neil (Chairman)

Dr.Ghulam Saeed

Ab. Manain

Dr.Daud Shah

Dr. Mehraban

COMDEV
MADERA
GCA
GAI
GAF
ARE
UNDP

S.Qasom Alemzacha

Dr. Muhihul lah (hal ini

$1) !: n$

or:n

Dr. S. Sul tan Masond

Mancy Hateh Dupres:

Dr. Fbrahioni.

nI?!I:

Mah' U Mustara

(II)II)

klalit Rahman

ar'mine?

I. Announcements:

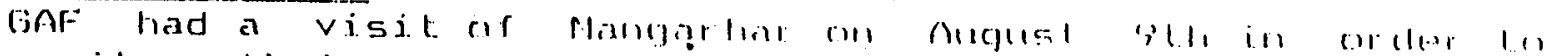

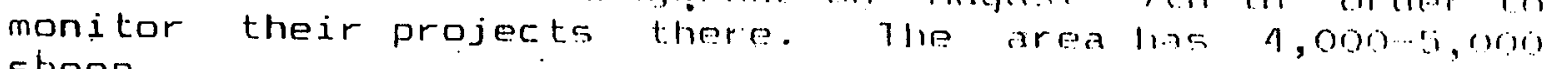
sheep.

The visiting team observerl a discose in kama lakit alul Shelman'. The disease was common in young shoep al 2 a months. The animal had high lemperalure, mere lhan $n:$

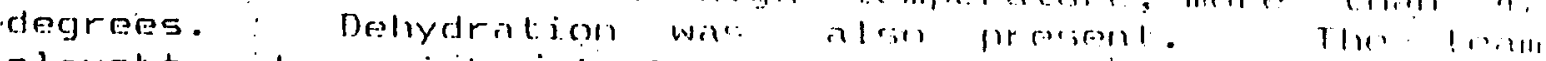

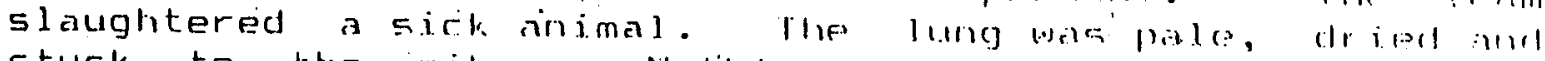

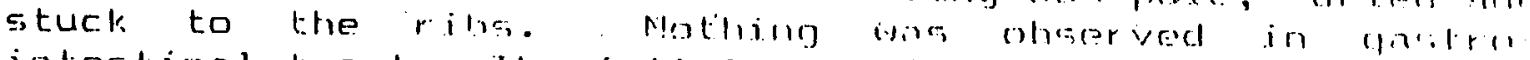

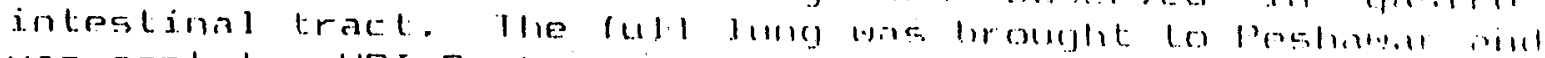
was sent to VRI Peshawar. The rmollt of the teste al yll showed the existence of Eroli in the lumg. Arocollim lu the statements by the farmors of lihe area, about aon ghrop were affected and many died. The ronrdinatimn mombrar a that the signs could not indicale what the diamian is. Bul it could be one of thr? followings:
a. CCPP
b. Pasteurella
c. Hepatica + secondary infection

GaF was advised to go to the area and linke some more sompla

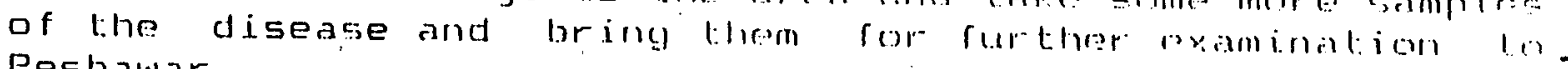
Peshawar.

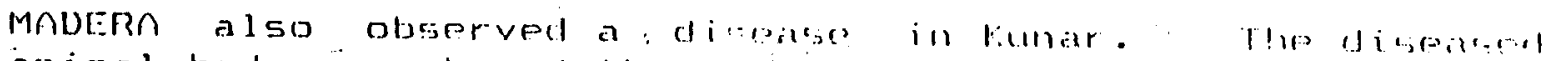
animal had a cough and the color of liver was palme ras lim farmer's have stated, lhe animals lio in 7-6 diyci.

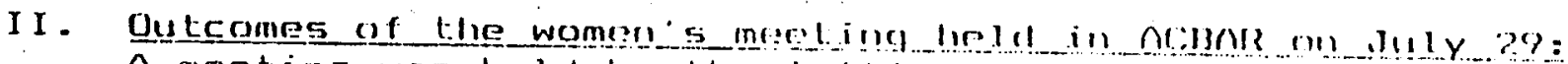

A meeting was held by the initialivere of the linmen componsm! of ACBar on July 29th. NIl. concerned individuals and organizations were invitad lo llis meeting. Thr main objective of the meeling wis to forlualie Afohom womm participation in different. sectors especially thosm whor thesr physical ability fil: in. It was said that woman ran easily work in animal huspondry and partially in animal

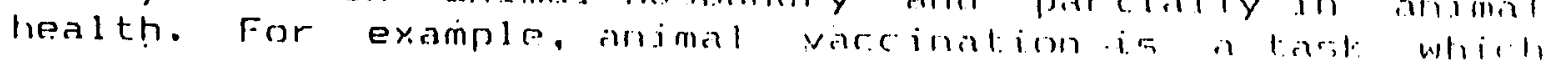




\section{9}

could be carried out by a woman. Poultry raising wastir primarily done by woman in the Afghan society. In Noorictin women do all of the agricultural activities in the field alld men handle animal husbandry: Very simple diagrams nf the disease cycle should be prepared and should be distrituted in the society.

It was mentioned that having direct training programs fol: woman in the Afghan society seems to be difficult, but this; could be achieved through training pre teen aged childran which in return they could train women of the society. The elder Afghan women also can easily walk around the sociely and possibly they could be used as trainers for the women of the community.

Visual aids will also help to give idea to women how to lake care of their animals.

II I Report on BVWs manual:

It was hopped that the manual be completed beforre this meeting. Since the members of the selected team to wor! ori this manual are very busy, they could not complete it.. thi $y$ 3 out 20 chapters are left and hopefully will be finisherl in a few days.

\section{The AGENDN}

for the next meeting which will be held

Tuesday, August on 27 at $0: 15$ a.m.

I. Announcements

II. Charging policy conjunction to "ACBAR Guidelines"

III. Questionaire about the out break of animal disense --DCn

IV. BVWs manual

V. Need (number) for the BVWs inanual. Pushtu, Dari, English 


\section{0 \\ A $[\cap \cap B$ \\ VETERINOISY COORIDINAIUIN \\ Minutes of the meeting held \\ on Tuesday sept to, 1991 in ncman}

nttrondants:

Dr. Neil (chairman)

Dr. Ghulam Salaed

Moh'd Mustafa

Dr.Gerrit. Wassink.

Dr. Sayed Moh'd

Dr.Sanaulhaq Ahmadzai

Dr.M.Zaker

COMDEVE
MADERA
L.B. T
DCA
GAF
CRAA
GAF

ARE:

1...?. I

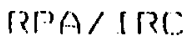

GAF

GAF

UNOPF

ACBAIR

\section{Announceinents:}

a. UNDP received information that duetta vaccine producing labs are not in the prosition to produce enough vaceine, so the UNDP representative visited VRI lahore last week. The director of the labs said that they can provide any amount or needed vaceinos. It was citaled that the request should get there 3 months in advance. Some money also should be paid in arvance. Muality control is adequate to export these vale ines. The vaccine producing source said thit from the beginning of October, 1.991; all vaceines will be packed in small bottles. Shelf life of these vaceines will be up lu one year if stored correctly. VIR Lahore also raid that CCPP vaceine may not need cold chain if the transportation and is done in one or liwo days. However, the shelf life will bo reduced. The same possibility is for Nruscastle Disearif Vaccine (NDV). ...

It was suggested that a representative from earh vaccine lab should bo invited fo a meseling to discuss the matters with lihe NGOs. The quostions should he sent to the above mentioned presson alone with lile invitation letter. A shar ceminar will be organiozol after technical datia from each lab har, been oxaminod.

II. Discussion over the "l iveslock hol velerinary gerving" ol the Guidelines for Inrlementalion of norifullural Projecte in Arqhanistan:

Discussion over this sretion of the buideling was siartal and some changes were matre lo it. lhe changos will lir included in the minules of the last mesting on tho subjert:

III: The BVWs manual:

The BVWs manual has been prepared and was distribuled for final comments. It should he submitted to GAF at the rnd of the current week.

IV. NGOs should send enough copjes of the UNDP dismaspamithreat... report forms to their field unjts. When thr dimengo oreurs, 
field workers should fill in these forms and send them to Peshawar office will in Peshawar as soon as possible. The the field to UNDP al be sending the reports collected from the field to UNDP along with their monthly report.

Will 11 be held on Tuesclay, Sext meeting
Sept. 24, 1991 at $0: 15$ in ACBAR

\section{The AGENDA will be}

I. Announcements

II. Continuation of discussion on the "Guidelines ....."

III. Any other business 


\section{2 \\ $A C B A R$ \\ VETER INARY COORD INAT ION \\ Minutes of the meeting held on Tuesday, Oct.15t, 199.1}

Attendants:

Dr.Neil Chesterton (chairman) Housaini

COMDEV
IRC/RPA
UNDP
CRAA
ACBAR

Dr. Daud Shah

Dr.M. Halimi

GAF / PRB

Dr.Ebrahimi

M.Sadiq Atayee SCF/US

Dr.Sanaulhag A.Z.

Bashir Ahmad

GAF

Khalil Rahman

I. Announcements:

a. The letter of Coordination group to VRI Peshawar, Lahore and Quetta was read in the meeting.

b. The disease-outbreak-report forms prepared by UNDP and DCA were compared. The one by DCA was more detailed but contained all the information required to complete the UNDP forms.

I I. The Ways NGQs Mark Their Medicines:

In order to prevent or reduce the misuse of medicines, most of the NGOs mark their medicines. GAF marks all of its medicines with the name of the organization and then puts serial numbers for each clinic. DCA uses code numbers for each clinic which are marked on each bottle or .... PRB, COMDEV, DCA and IRC/RPA also stamp their medicines.

I I - Staffing Responsibilities with NGOs:

The question was raised by COMDEV. COMDEV wanted to know what benefits ( Eid gifts) go to the field staff of NGOs. Also what should be done for thestaff fo a clinic if they are shifted to another district. It was determined that different NGOs have different policies.

IV. BVWs Manual:

The Dari version has been completed and will be given for printing. The Pushtu version has been done 50\%. COMDEV will translate it into English. The AGENDA for the next meeting which will be held
at $8=15$, Tuesday, Oct.15, 1991

I. Announcements

I I Chaŕging policy - "Is it working?".

III - PRB will report about its clinics in Takhar.

IV. CRAA will report about BVWs manual.

V. Present difficulties with Kunar and Nangarhar.

VI. SCF/US report about its vet. and poultry projects.

VII - UNDP report about latest monitoring trip. 
213 


\section{Attendants:}

Dr.Neil Chesterton (chai.)

M.Sadiq Atayee

Dr.Daud Shah

Dr. Sayed Mohammad

Sayed Qasem Alemzada

Dr.Ghulam Saeed

Khalil Rahman

COMDEV
SCF-US
GAF / PRB
GAF:
DCA
MADERA
ACBAR

Dr.Mehraban

Dr.S. Ahmadzai

Gerrit Wassink.

Eng.Kabir

Mohibullah Halimi

Aminullah Sharifi
UNDP

CRAO

DCA

PRP

I)CA

APA

\section{Announcements:}

a. UNDP asked the NGOs to send their field reports along with their monthly reports. If there is any disease outbreak in an area, the disease outbreak report also should be enclosed.

b. UNDP had a veterinary seminar in Quetta. interesting idea from the seminar in duetta. An that farmers. animals could. vaccinations where keeping be colored for difreront difficult. There are few vaccination cards id goats should be vactinated ther diseases that shepp arid colors could be used ror differentst. So, difreront: could be marked on for different vaccines. The color coordination meeting the head of the animal. The the same clours as Quetla recoment idea suggested we use

II - PRB report on trip to Baulakhshan and Takhara

established 3 had a trip to northern provinces.

PRB

a. Chayab and sub-clinic in Rusting on 3rel of Octoher.

b. Khoja Ghar and sub-clinic in Yangi Qala on 3rd October. c. Taluqan and sub-clinic in Farkhar on 12 th september.

PRB said that another one will be opened in Taluqan city in one or two days.

According to PRB people were very happy with charging policy. PRB will give detailed information about its
charging policy in the next meeting. I I . CRAA renort about BVWs manual and present difficulties with The Dari version of BVWs manual had heen completed and will
be given for printing.

CRAA has been working in kunar and Nangarlar. CRAA said that the acceptance of the veterinary programs in Nangarhar 
is better than Kunar. But the civil situation does not allow work to be done. IV. SCF-US report about its veterinary/animal husbandry

SCF-US. Women's Income-generating Department has project in Basawal and Hazarnaw of Nangarhar a poultry Since the Women's program Agriculture Department took can not monitor the project, the project.

According to the Agriculture Departinent of SCF-US, the project was going to distribute 3,150 chicks of 8 -week old to 150 families. The chicks were to be distributed to widows, disabled husbands and poor families. Due to been able on US aids to inside Afghanistan, SCF has not distributed to fulfill the promises so far. SCF has families. Fach family. Feomi (Egyptian breed) chicks to 39 chicks. The agency drinker along with $17 \mathrm{~kg}$ feed to large feeder and a large one against Newcastle disease and family. Two vaccines, disease were also performed disease and the other for Fowpoy disease were also performed. A professional paravet and 6 assistants are also busy with the projects. SCF said that will also be implemented. The fund to this project has been provided by the Asia
Foundation.

V. Any other business:

It was suggested that the number of BVWs (trainees) should be limited initially. in the program. In most proposals Rs.50/day (accommodation and transport) will be paid to the
trainees. payment. But most of the NGOs did not agree with. the of the program, they will the people knew about the benefit suggested that some money should ily join the program. DCA order to be motivate them tould be paid to the trainers in number of BVWs should be determined good training job. The

DCA is going to employ some of the vaccinators from SCA and train them. DCA has already hired one of them and one from another place. Both were tested and found to be proficient.

DCA is going to build some clinic buildings inside Afghanistan. They will ask GTZ for advice. If other NGOs are interested GTZ should be invited to the next meeting.

DCA said that bee keeping should be investigated. There are quite a lot of Afghans with experience in this field. DCA is looking for a person who has specialties in bee keeping. should be launched in orted by NGOs and some investigations Logar and IRC in Paktia have bee keeping programs.

ARC in 


\section{6 \\ $A C D A B$ \\ VETERINARY CUIURDINAT ION \\ Minutes of the meeting held on Tuesday, Det.29, 1971}

Attendants:

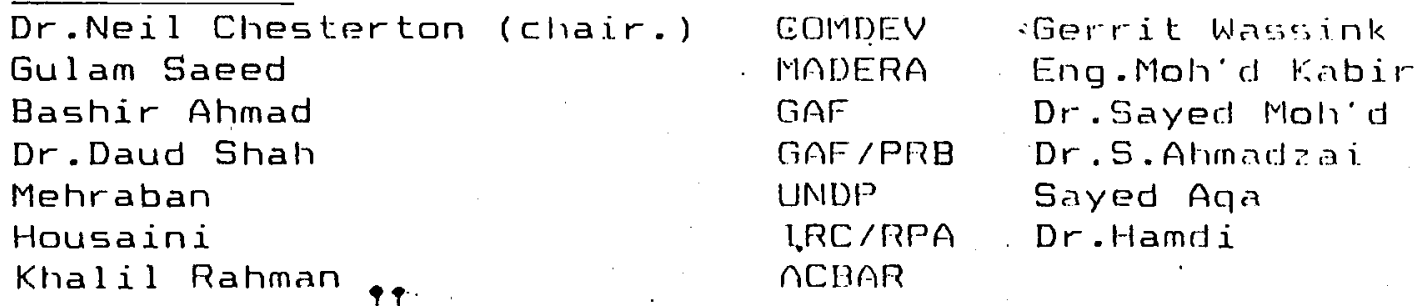

DCA

PRB

GAF:

TRAA

AIRC:

L. . . I

I. Announceménts:

a. MADERA talked to VRI Quetta about supply of vaccine last' week. But VRI-Quetta were unable to supply

- rraccine at short rotice due to curfew existing in that city. DCA said that curfew might be for a short time. DCA received some vaccine recenlily. DCA also monlioned that, vaccines could be received easily through MCI office in Quetta. MCI charges $2 \%$ for shiping and other services. UNDP proposed that time of different: vaccinations should be identified and in a 1 ist 1 he need of different vaccines for lifferent application times should be sent to supplier(s): GAF said that VRl Lahore will provide vaccine with an iffer of 15 days in advance.

The shelf life of vaccines was distussed. It was said that the drastic change of temperaturo can effort vaceines more than the long term constanl warmer. temperature. According lo data from a N.7. velerinary magazine, the change of certain degree in temperalure can increase/decrease the shelf life of vaccines as follows:

deqree tem?.
4 degrees
14 degrees
24 degrees
34 degrees

\begin{tabular}{l} 
shelif life \\
\hline in montihs \\
18 months \\
7 montihs \\
4 months
\end{tabular}

II - UNDP monitorinq reprot:

This will be reported in mest meeting.

III - PRB charqing policy:

PRB has established 3 clinics in Takhar. Prob has sitarted applying charging policy in these clinics. According to PRB, the policy is working well 50 far. One of PRB clinic's also has started training 12 BVWs. Once the first group is finished, another group will be selected. According to PRB's policy, the money received for vaccination goes to vaccinator. The money for medicine sold alsu goes to thr person who sell it. $40 \%$ of the cost of medicine is rut: from the salary of paravel or BVW. If lhe medicine was not. 
sold at all, paravet will be paid full salary.

VI. Any other business:

a. It was said that the medicine produced in Iran is possibly of high quality than Pakistan. Medicine is much cheaper from Iran.

b. The reprot from Veterinary section UNDP-Quetta regarding the coloring of animals for vaccinations was distributed to the meeting. This will be discussed in the next coordination meeting. Mr.John Woodford, UNDP veterinary officer in Quetta, will also be invited to the next meeting.

c. DCA contacted GTZ for the construction of its clinics inside Afghanistan. GTZ agreed to send its architects to evaluate the issue. GTZ will be invited to the veterinary Coordination meeting Nov. 26th.

d. The problem of getting permision from Pakistan for commodities to be transported inside Afghanistan was orice again discussed.

The AGENDA

for next meeting which will be held

at $B: 15 \mathrm{am}$, Tuesday, Nov. 12, 1991 in ACDAR

I. Announcements.

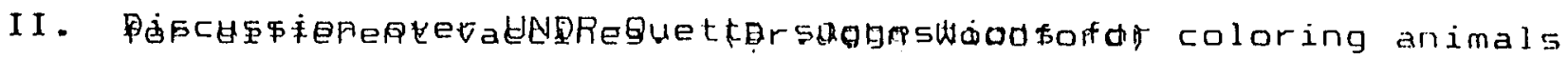
III. Any ather business. 


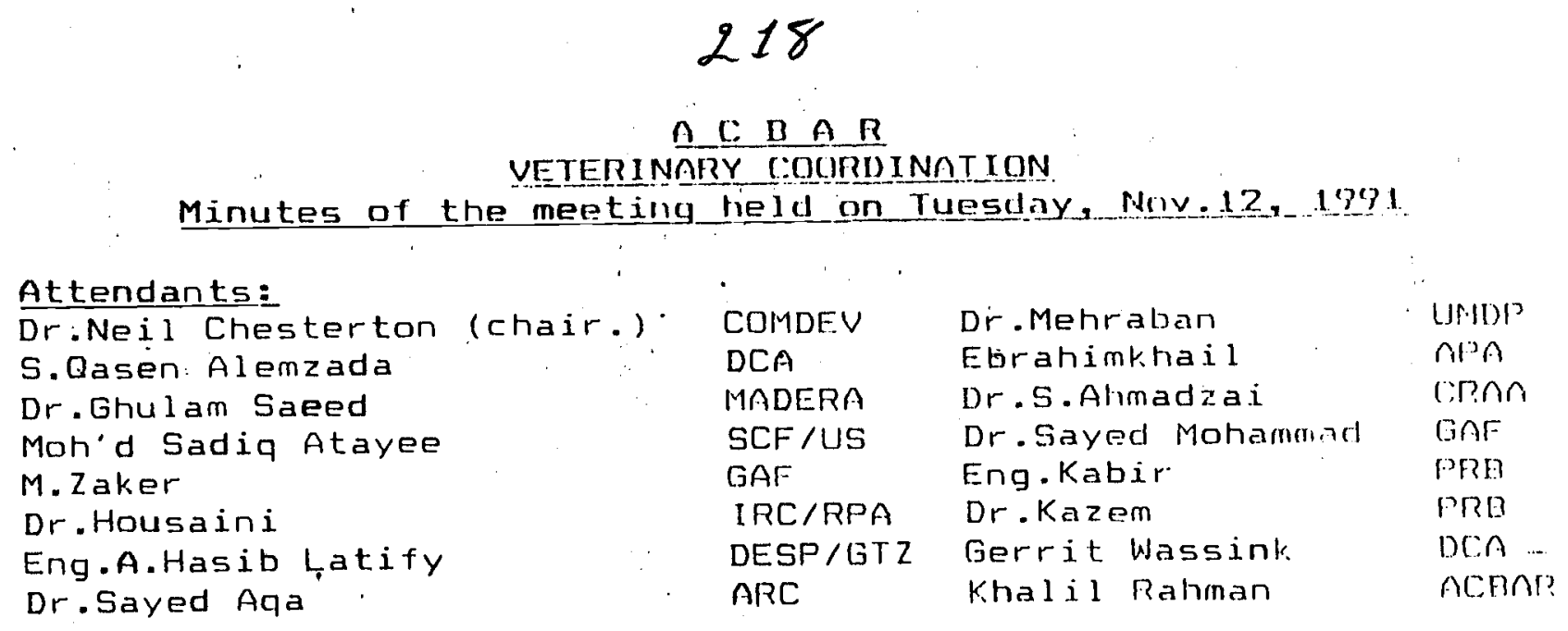

Attendants:

Dir. Mehraban

Ebrahimkhail

nOA

(imon

Dr. Sayed Mohammad GAF

Eng.Kabir

PRE

Dr.Kazem

DCA

Khalil Rahrnan

I. Minutes of the last meeting:
a. The word "easily" should be deleted from the minutes ol the last meeting. It should be read "DCn has beon receiving vaccine through MCI, Quetta".
b. The statement which says "If the medicine was not: sold full salary will be paid to paravet.s and nVivs." Actually BUws do not. receive salary.

\section{I'I. Announcements:}

One of DCA's field officers was going to go to [3aghlam rull was caught by dacoits north of Angoor Hadn in Afghanistan. He was asked to give Rs.300,000 but finally paid Rs.A5, Mmo. DCA believes that there is no political aspect hehind lw. incident.

III. GTZ explanation about its construction program:

In one of the previous vet. Coordination montings orn mentioned that it needs to construct some building for its clinics in different. narts of Afghanistan. DCA contiarted DESP/GTZ in this regard. The members of the conrdillation were interested in the matter and suggested to invite lirz 40 come to the coordination mesting and explain its policirm; regarding the construction of buildings.

The director of housing. of this agency took palt in coordination meeting. He said that DESP was formed in 1.99? The agency has been trying to find out the economical waye, of fuel consumption. This is in order to avoin tile

- destruction of natural resources especially wood in Afghanistan. The agency also has a housing and constructim section specialized in mud buildings with dome ronfinu system. DESP has built around 3,000 houses in reflugee camp. so far. It also has constructed some buildings for HCL, IC. and Help Holland. Generally two systens of roofing ars built by the agency: 
a. Domes structures with square $(25$ in $25 \mathrm{~cm})$ sun dried bricks.

b. Half a modern system is used in which, concrete beams with slabs/oven dried bricks are $1.15 e d$.

Before starting the construction, the project takes soil samples from the area and bring them to the soil lab in Peshawar. After analyzing the soil and finding the nature of the soil, materials will be selected. DESP has a masons training center in Kacha Garai, Peshawar. The research has been done on local construction materials. In stabilized bricks by pressing machines 4.5 to $6 \%$ cement is $\mathrm{mixed}$ wil:h soil and sand. DESP has construction program in Khogiani of Nangarhar province.

DESP said that the cost of a timber (teer) in areas 1 ike Jaji, Ghazni and Khogiani is Afs.1500 to 2000. Compared to this high rate of timber, domp roofing will be economical.

UNDP agreed that NGOs consider construction of their clinics on a contract base by DESP/GTZ. DESP was asked to provicle estimation cost of an average clinic buildings (4 rooms) in different areas and report it to the next coordinatiul meeting.

IV. RPA/IRC report about its veterinary projects in Afqhanistan:

RPA was established in 1990. In August 1991, veterinary programs were started in Sayed Karam, Moosa Khail, Jani. Khail, Ahmad Khail, Lajza Mangal and Dandi Patan district.s of Paktia province and in Azro district of Logar province. All the clinics have the required staff. Only Lajza Mangal and Ahmad Khail.Clinics are serviced by one Veterinarian and one clinic. Up to eleven persons will be trained in ench clinic, one as a store keeper and 10 as BVWs. At present only Jani Khail, Moosa Khail and Dandi Patan will be considered for BVWs training. After evaluating these three? places, the training program will be expanded to other clinics. Finding a good building to set-up the clinic is a problem. In Jani Khail and Moosa Khail, part of the storage buildings of IRC are used for clinic. In Dardi Patan, the. clinic has been stationed in one of the commanders houses.

The work in each area startied in consultation and agreement with the shura's. In Azro there are two shuras. They are not unified so far, so the activities have not started yet. There is no work in Syaed karam due to fighting around Gardez.

Staffing is still a problem with NGOs. One suggestion that has been considered by UNDP in consulation with DCA is the upgrading of the best paravets to the level of veterinary assistants. This 


\section{0}

training should be given to one NGO. Since DCA already has, a training center, the task should be given to it.

The duration for training was suggested to be 6 months.

GAF also has a trainirig program. It's looking for somp experienced veterinarians to teach in its training center on the ad-hor basis.

The Dari version of BVWs manual has been completed from printing and will be available in a few days.

NOTE: NGOs should bring their requirements regarding the number of clinics needed and the area to the next: coordination meeting.

$\triangle C \cap \cap R$

VETERINARY COORDINATIION

The AGENDA for the next meeting which will be held at 8:15 am, Tuesday, Nov. 26, 1991 in ACBAR

I. Announcements

II. DESP estimation of construction cost of the NGOs clinics

II . Any other business 
221 


\section{2}

A $: B \cap 1 ?$

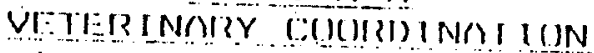

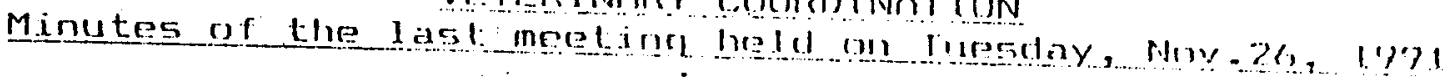

At tendants:

Dr. Neil Chesterton (chair.)

Dr.Daud Shah

Wilfrid Herrich

Eng.Latify

Eng.Homayun

Dr. P1elnrabarn.

M.Nazir wardak

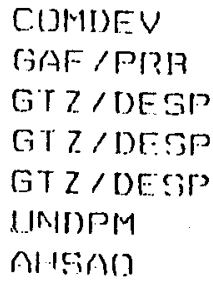

Dr. Sinyed rigis

Gerrjt Warsink

Dr. M. Iln 1 imi

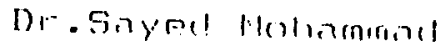

Dr. S. Ahmarlsai

M. Anill

likal i Palman inl?!:

lin $\mathrm{C}$

lier:

ene

ranis

rats:

a?lin?

I. Announcements:

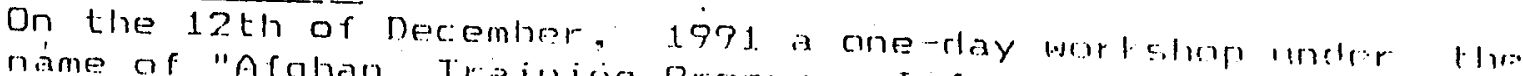

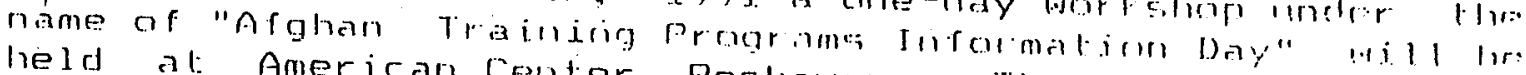

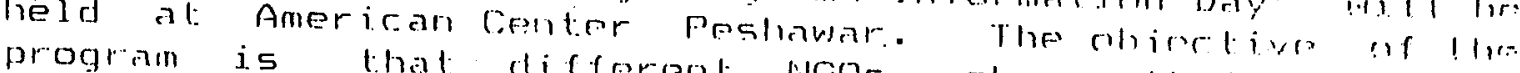

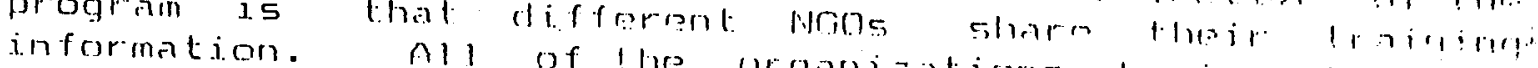

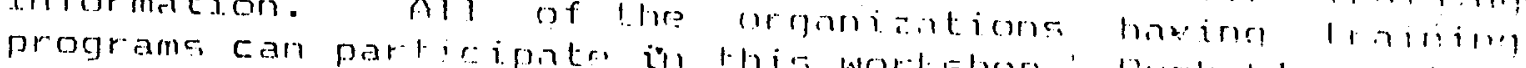

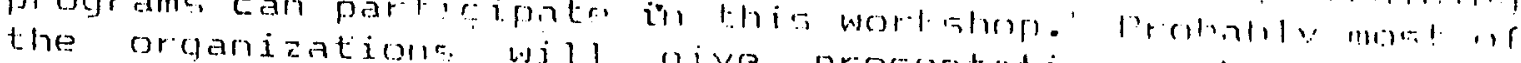

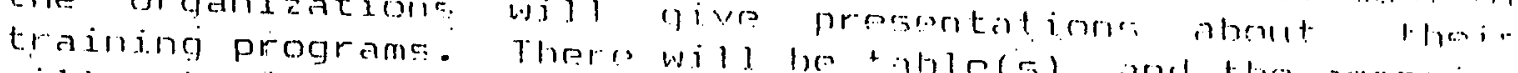

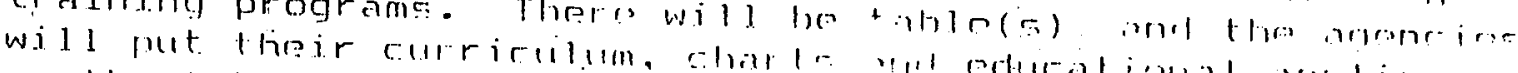
on the table. The program inil

II - BTZ/JESP erimalion or crol:

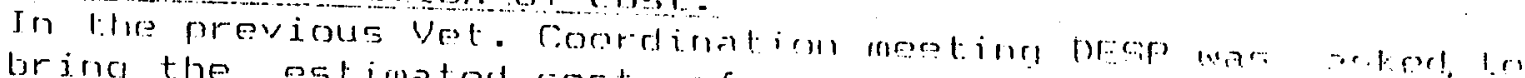

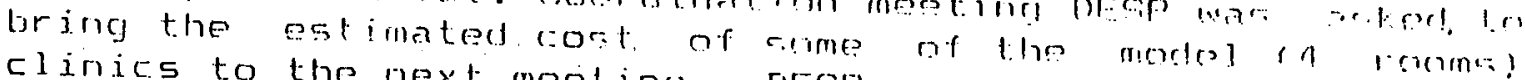

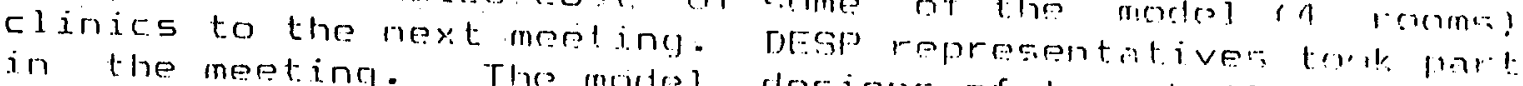

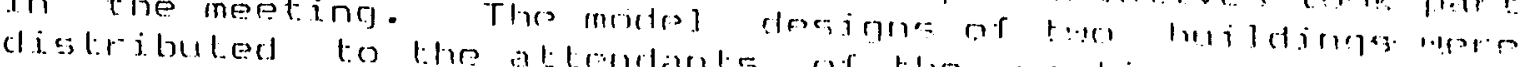

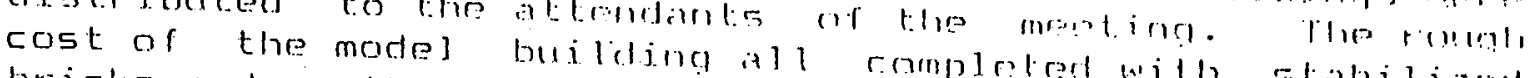

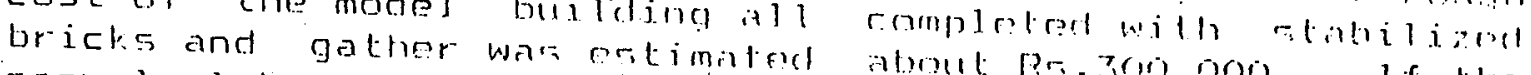

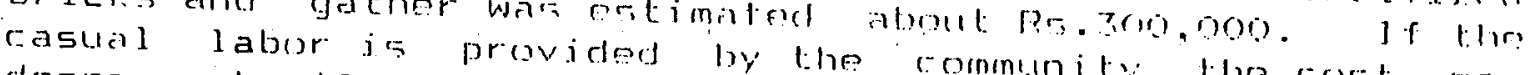
decrease by 10 percent. DEgp said tontenty the comt may

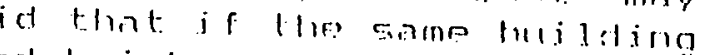
wooden doors and windowe motided brick and in sterad of

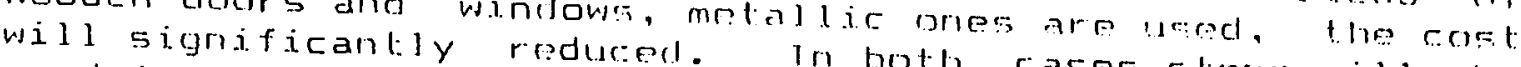
used in the foundation. Under hoth rases folom will ho the time.period for the or normal cimalic tonditions, building will be about of conetrution af a stabilized when all construction maing a monthe, and this is the times walerials are reaty on the sito.

LINDP said that the comstivetion of

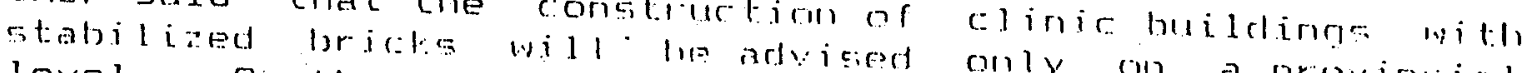
level. On the district levelo, lower only an a provineia! preferable. The ownershin of life land and buildinas are

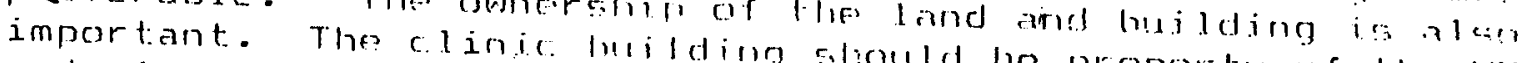

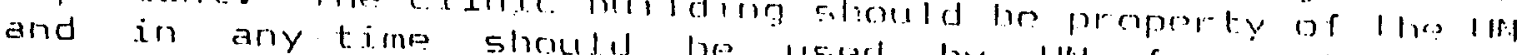

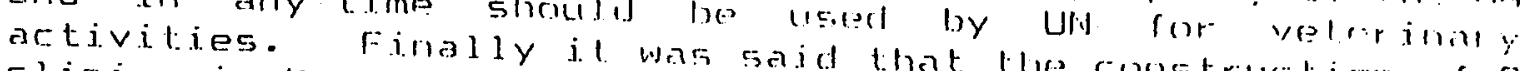

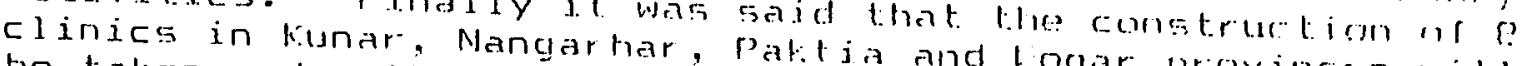

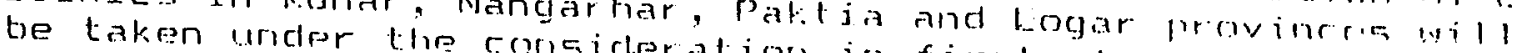

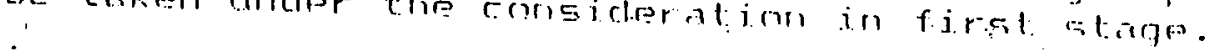


223 


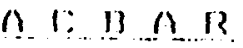

VETERINATRY COOJISI)INAIIUN

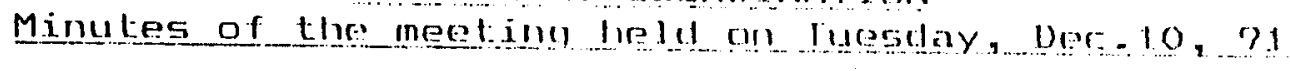

\section{Attendants:}

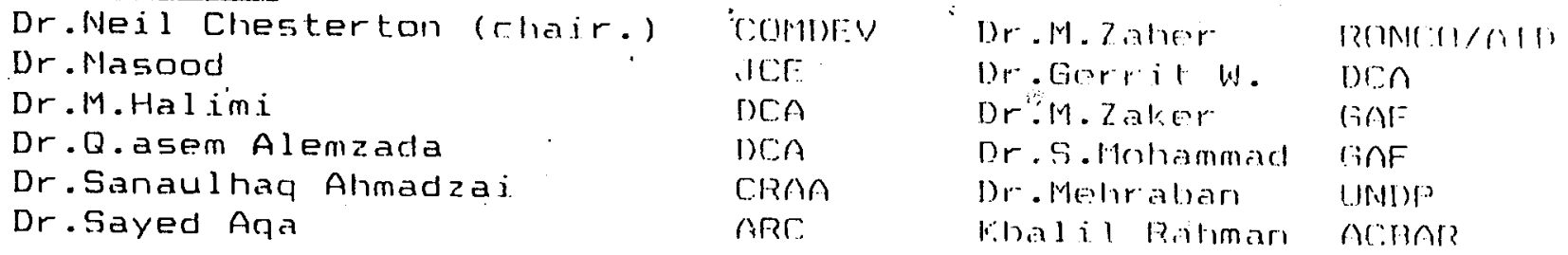

I. Announcements:

a. GAF was informed by Jehatf Consulting Engimeers (ack) bhat the signs of a disease were seen in kochies animals in $r$ ana Daka, Nangarhar province. GAF acked the kochies to hring ia samples from the inferted anjmal to Peshand. The sample

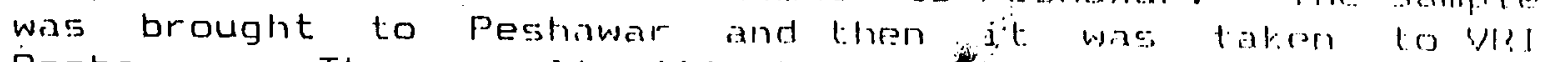
Peshawar. The result will be recelved probialy on roset Thursday. One of the differential diagnosis ware Copp. rist is sending a mission to thr area to observe loh ine ident:

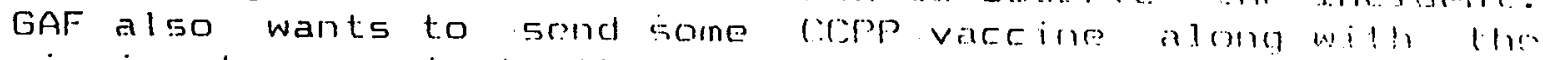
mission to vaceinate the animals. Gef was adviecol mol la use any vaccine brefore taking sorkm samplese nl loisel lis

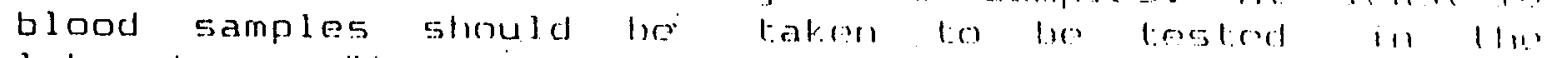

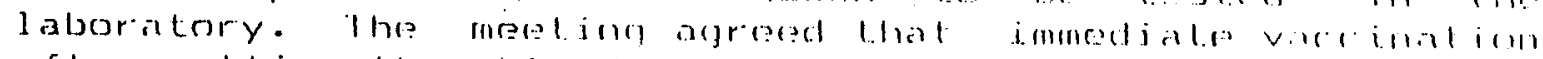
after getting the blood samples would he advisablo if cifple was suspected. If the results from the were nogative lor.

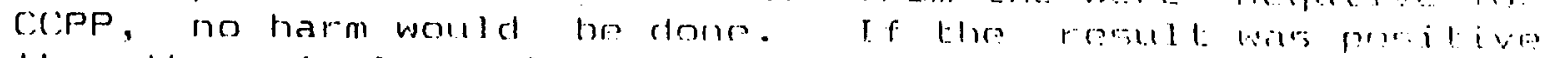
then the animals would alrearly he protoctod.

GAF said that previously the dismase was mot linom in the area. It the disease je COPP, it has moret probinbly borm

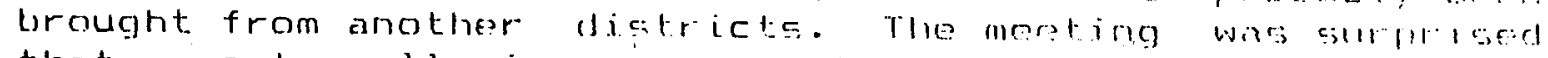

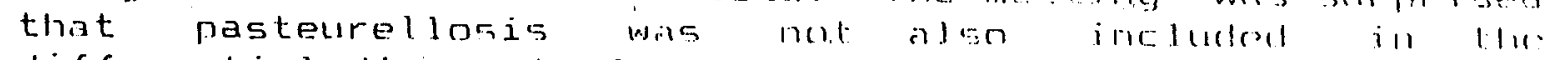
differential dianuesie from the lat).

b. Based on the decision of the proviour vel. dourdination meeting, some of the NGos solested silies fror huilding new clinics as follows: .

$D C A$

$\begin{array}{lll}\text { Narigarhar } & \text { - Hearak } \\ \text { Paklikis } & - & \text { Mohbala } \\ & - & \text { Harmal }\end{array}$

- c.RAa

Nangarliar

Kunar

Ac:hin

Franclish

ARC

Logir

- Khorshj

-. Mlaruare 


\section{5}

I . UNDP monitoring report about trip to Paktia:

UNDP monitoring injssion visited UNDP rumeded clinic: al ll! and GAF in Paktia province. IRC has recently established some clinics there. IRC's work was evaluated as suciescill] in Paktia. The clinics were started with the agresmont of the shuras. pople have recepted the charcing ridiry. Recruiting was done except in soine areas. There are problems finding professional neonle iri the area.

GAF has moved from Tanai to khost. There was a huge demand for veterinary services in khust. GAF also works jil jaji. In Jaji, some people are not happy with charging! Therefore, some people pay and some do not, but GAF fidid staff(s) are still continuing their services to those who oppose charging. GAF said that the $40 \%$ for medicine has to be charged. It is up to the rield staff if they forgive the extra charge $(10 \%)$ for medicine and the treatment fee.

III. BVWs manual:

Since there were some major mistakes in the BVWs manuil. they were corrected and will be returned to the compuler with the coirections.

IV. Any Other Business:

Some while ago Mohammad Rahim, DCA veterinary assistant, wats going on a monitoring inission to Bamyan. On the way, he claimed, he was stopped by dacoits in Angoor Hadi. He was kept by the dacoits for almost one and half month. The money (Rs.45,000) was taken from him. DCA sent a mission lo investigate the incident but did not find any sign thest Mohammad Rahim was stopped by anyone. Mohammad Raliin. leil: $D C A$ and did not come back to the office when he heard that the case was to be investigated further.

It was suggested that field staff should not be given their salaries in advance. The salary could be handed over to him by a reliable person of the same area where he works. It was also suggested that for bulk purchase of office supplirs and needs chicks should be lused in stead of cash. It was also suggested. that à reliablè person accompany staff to the area.

Please note that the next Velerilary Coordination meeling wijl be held on Tuesday, January $7 t h$ 1992. The Aqenda will be
distributed later. 


\section{6}

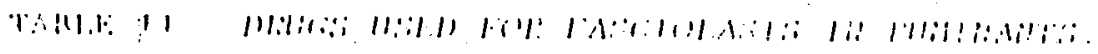

\begin{tabular}{|c|c|c|c|c|c|}
\hline Cincmlenl name & 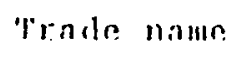 & Rrongmmondolol & dos:? & liffrat: on & \\
\hline , & & 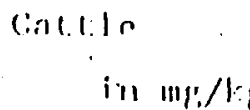 & iliaril & $\begin{array}{l}\text { Immatame } \\
\text { liaralolal }\end{array}$ & $\begin{array}{l}\text { matura } \\
\text { iagra: }\end{array}$ \\
\hline
\end{tabular}

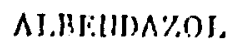

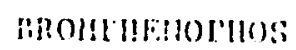

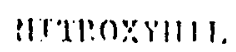

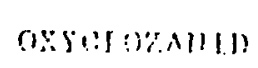

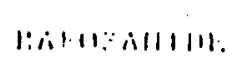

$|1 ! 11: 1 . A| 1|1| 11,1:, 111$.

$1: 1:: 111 \ldots::$

neroli::

Mnखाi:

liplis

$\because: 111$ i 1

l' आ1i,l.
Vallia::(1)

$11,011.0$ $\because \because 11$

$1 \% .011 .0$

1111111.

$11,1110$.

$10.01) .01$

$1 ; 11, \cdots$

1

3

1.

?)

1

1.?

1

I

$1 \therefore 11 \cdots 11$

$11,1111.11$

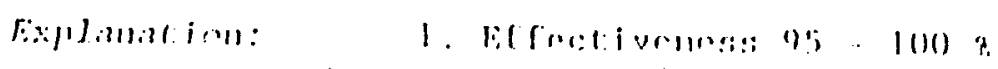

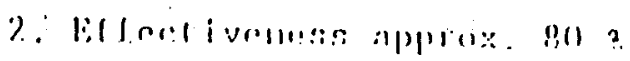

3. Herectilvanoras applas. 60 ?.

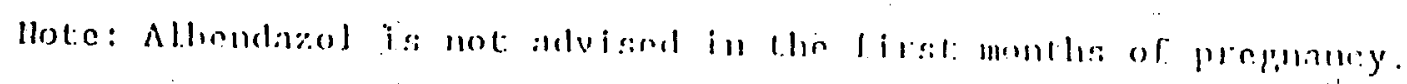

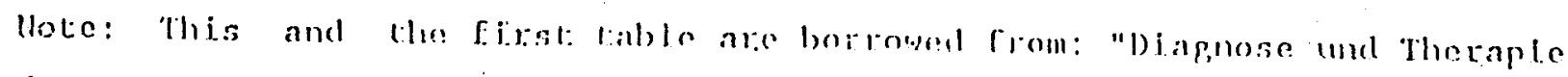

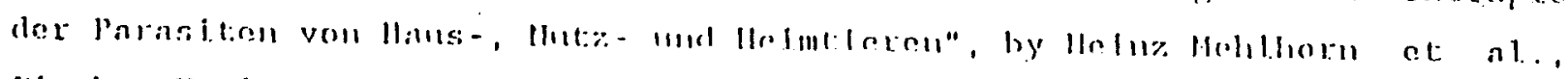

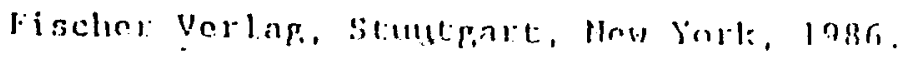


$227-$

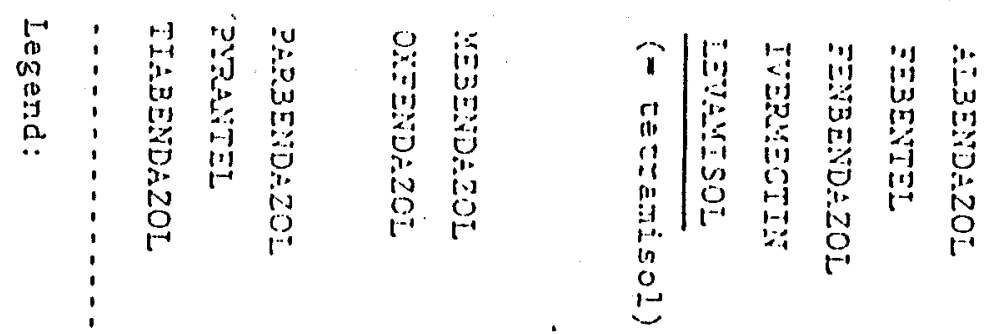

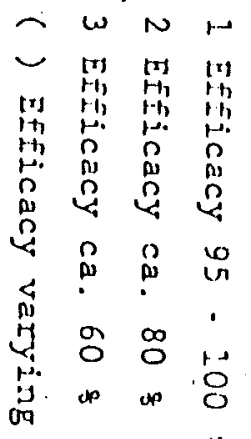

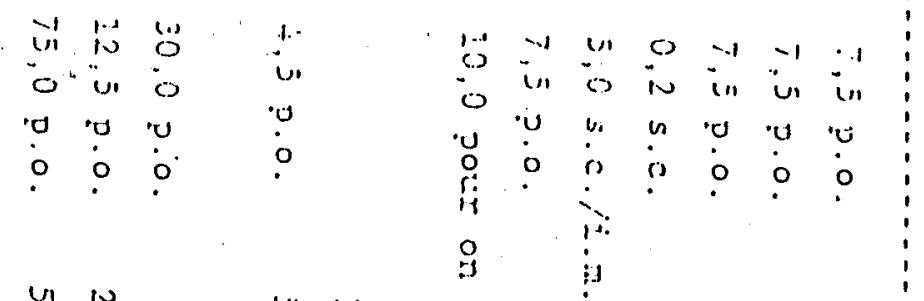

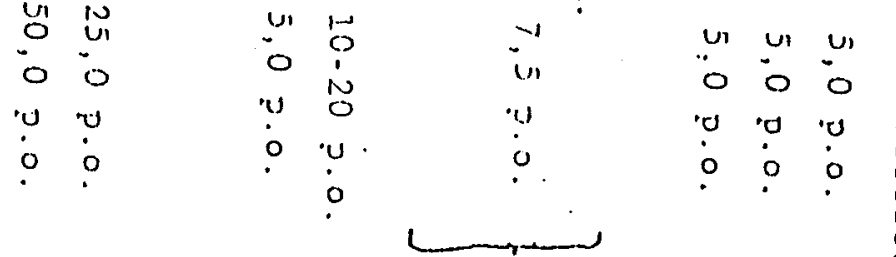

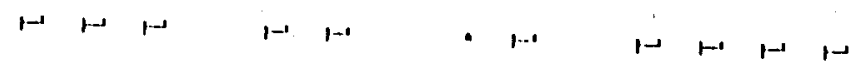

(.)

:

in : $\quad$ i $\quad$ in is $\widehat{N}$

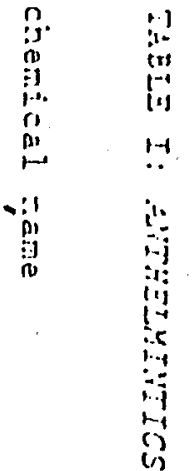

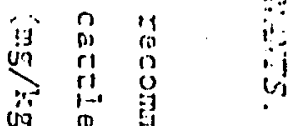
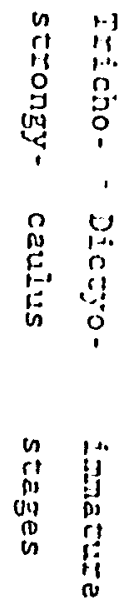


\section{DUTCH COMMITTEE FOR AFGHANISTAN}

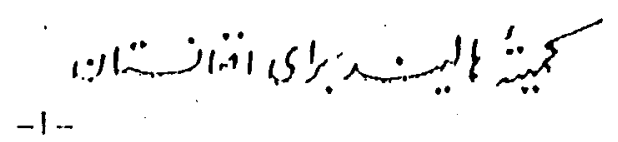

\section{ANTIIELMINITICS}

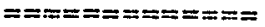

The cycle of the Nematodes, Cestodes ami firmatodes implices, (because the development of the parasites takes partly place oulside the body of the host) that there is alwas a rejufection of thill hosi.

In the control of chdoparasices it is important lo kece the number of parasiles in the host at a low level. It: is impossililo and also not necessary to free ali animal $100 \%$ of endoparasitus.

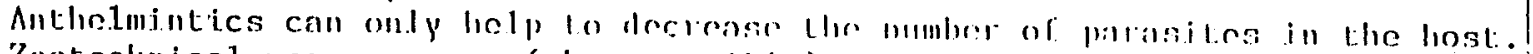

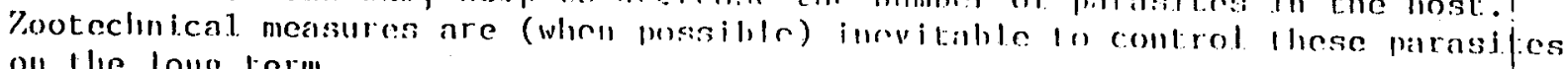
6 on the lons, term.

The ideat anthelonintic agent: should:

-have a brond spetrum of activity against mal.ure and immature parnsites

(including inhilited larvac)

- be easy to admintster

-lave a wide margin of safety

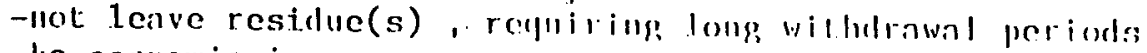

-he economic in use

\section{MBCDIINNISNS OF" NC"IION}

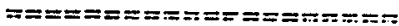

1-Tuhibitors of mitochondrial reartions.

These drugs exhaust the encrgy sysicen of llor pallisildr.

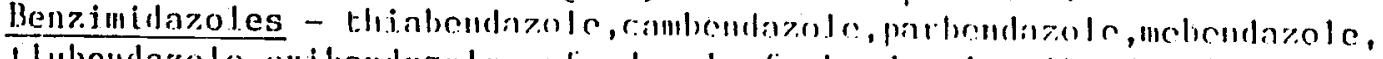

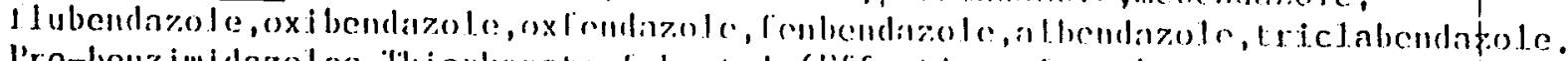

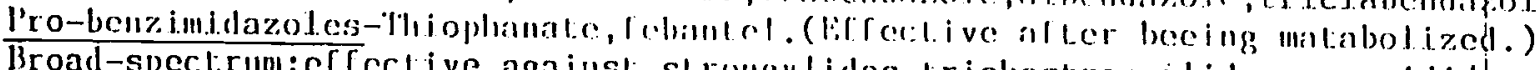

Broad-spectrum;effective against: strongy lides, trichostrongylides, ascarididtice.
lungworm, cestodes, (1.iverfluke).

The newly developed benzimidazoles are ledtor offective agninst larvae.

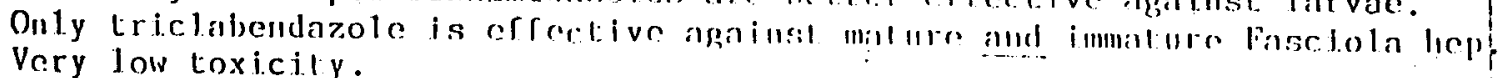

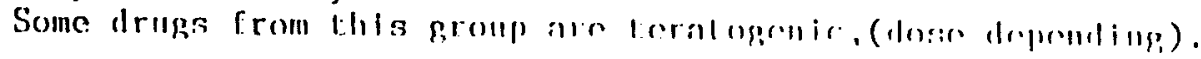

2-Clublinergic Agonists

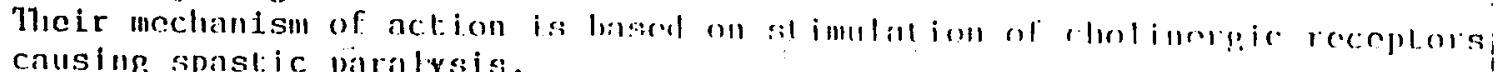

Imidathiazoles- levamisolo (10limisolo)

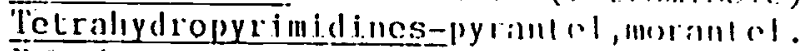

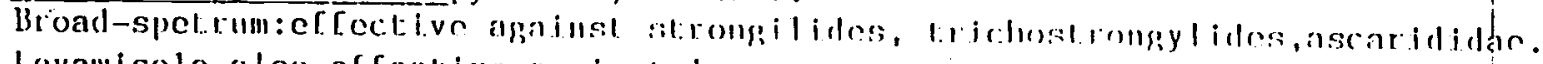

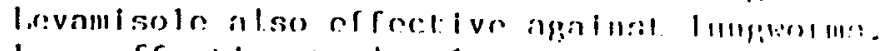

less efrective lin laval stages.

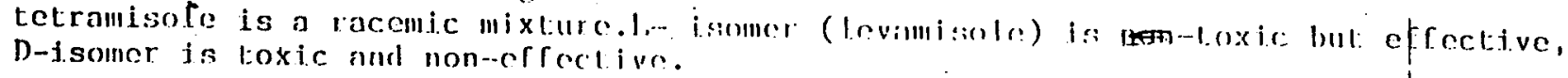

\section{Postal Address}

IIIINIPSIIY ROSI OHIICE

nori:o. 79?

ranalvan - rariolan

\section{Telephone}

4114? $1 / 15,36$,
Tolex

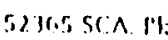

Bank

CRINUIATS RAIK

PISIIAIUAR

A./r restronmon 


\section{3-Avermectines}

\section{9}

the drug potentiatc the inhibitory effect of $X$-amino butyric acid (CABA); neurotransmit: Selective toxic to parasites cansing paralysis.

Ivermectine.

Very effective to nematodes and lheii larvac as woll. as inhibited larvak.

Slow elintuation (2 weeks).

Non-toxic in most animals. Pixception: some don races.

4-Cholinc esterase inhibjtot:s

Inhlbition of choline colorase callses spastic partysis.

Organophosphates:dichlorvori, L.richlorron.

Effective against nematodes in st:mach and small intestine.

In hotses effeclive againsl. larvic of Castrophillus.

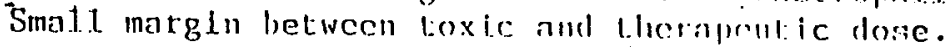

5-Uncouplers To oxidative flumplorilial ion.

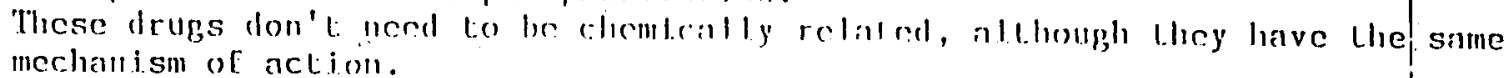

They interfere in the encrpy system of the parasite causing exhaustion. Bipheniles: broomfenoplios

Salicylanilides :closantel nic Insamidr, oxyclosanidc, rafoxanide

Niclosamide effective agninsal costudes.

Most salicy lanilides effective against. letsciola llopatica.

Toxicit." moderate.

\section{6-0thers}

Piperazine interfores in neurn-muscular stimulal ion.

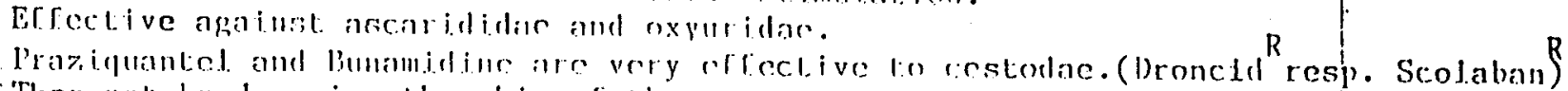

* They act by dambing, the skin or lihe wom.

lose depends on:

- way or arluinis

- speciss

- liody veiplis:

- worms youl wanl lo conlerol

- per lotrular llever ia alvalya a max. and min. Hose kenowill.

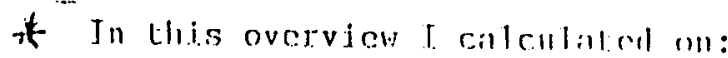

- mi.nimum dose per rormula

- otell dose

- bazar prices

* Against inhibited larvar only the modern (pro)honzimidamoles and iverméctine is effective. 

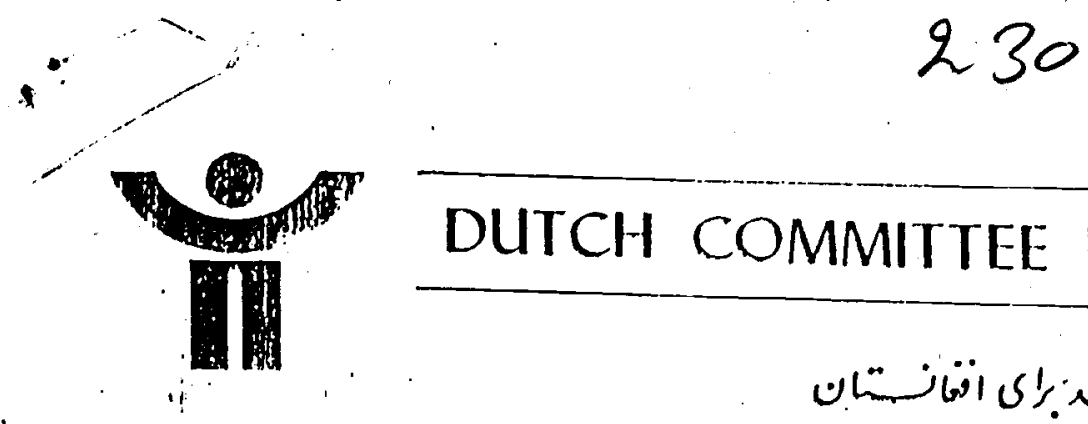

\section{DUTCH COMMITTEE FOR AFGHANISTAN}

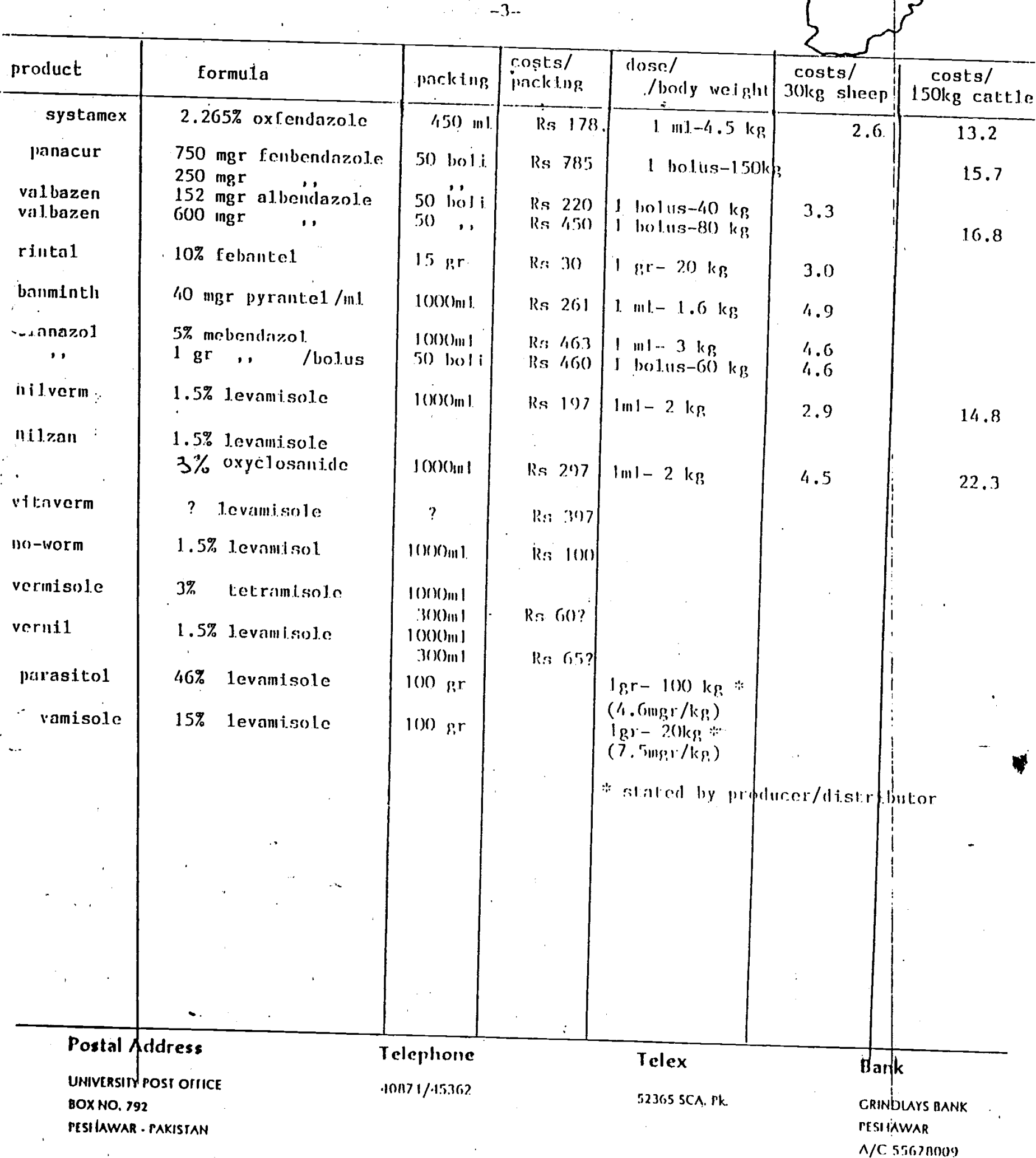


LEVAMISOLE

$1516 \quad 1009$

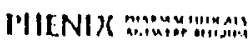

$\underbrace{}_{-10}$

Th:

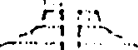

romula:

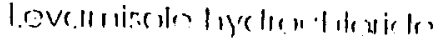

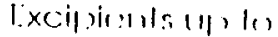

Dosage amel

adminisíncilion:
231

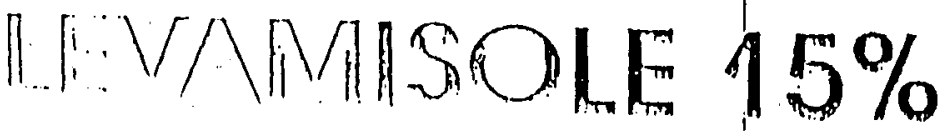

(Waler-soluble powder)

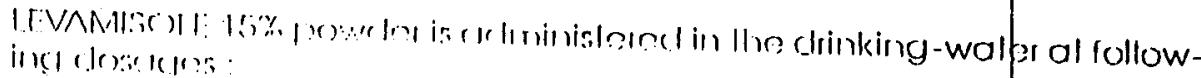

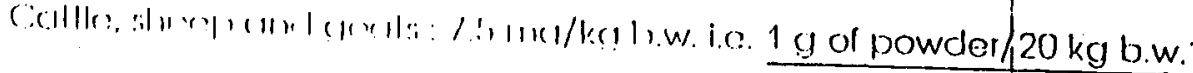

roulliv

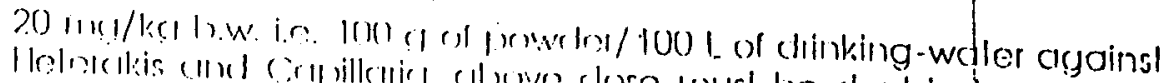

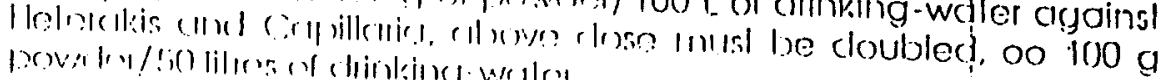

\section{PARASITOI Ponule:}

\section{DESCIIIPTIUN:}

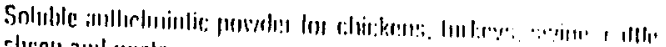
S

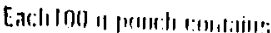

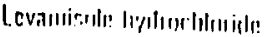

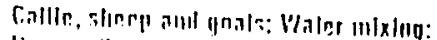

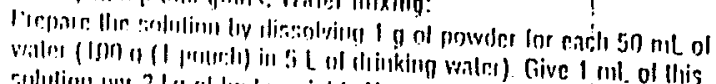

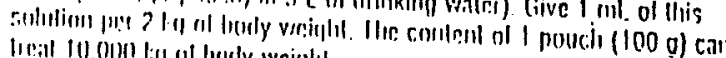

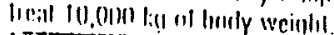

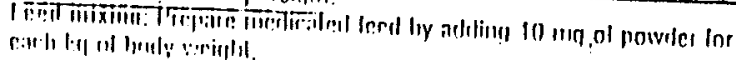

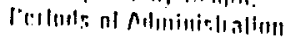

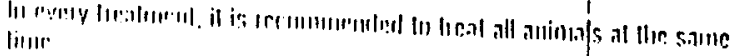

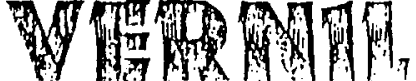

Drinkable solution

EVAMISOLE HYDROCIIIORIDI

I

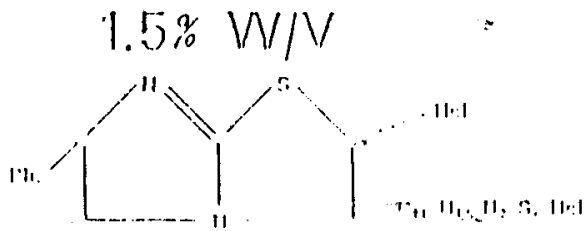

Hill. wt 210.11

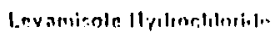

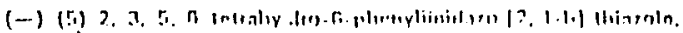

A RIEAB YEILOW SOIIIIIUH

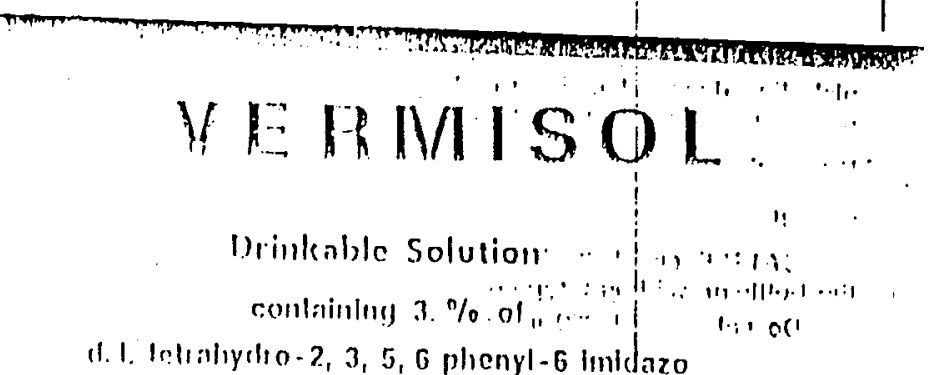

(․ 1-1) Hhlazole hydrochilorlde

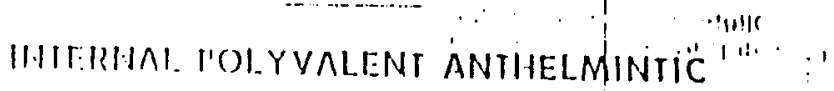

SASIROHHRSTINAL AND'PULMONNARY

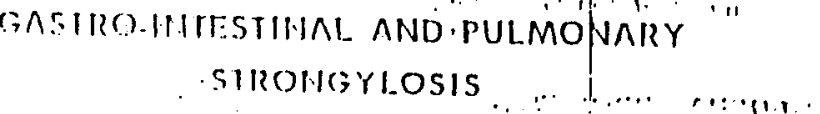

ror mat ndmintsiraition

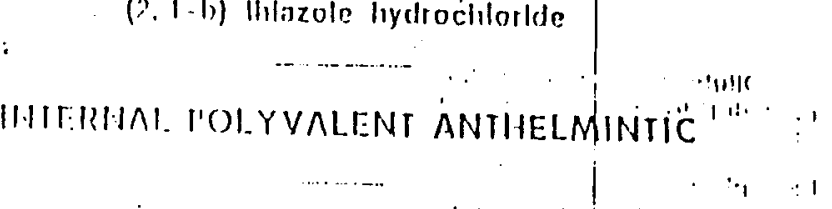


A C B A $\dot{R}$

VETERINARY COORDINATION MEETING

MINUTES

January 9,1990

\section{Attendance}

J.F. Rubin

Dr. Sayed Sultan Masood

Martin Valks

Dr. Samsore

Sayed Omer Mujaddadi

Gert-Jan Duives

Amanda Edwards

Mark Pont
VSF

DCA

DCA

DCA

DCA

DCA

SCF (US) :

Afghanaid
Dur Mohammad

Juel Delsart

Xavier Bouam

Najibullah

Dr. Menraban

Hesamu 1 haq

Sayed Mohammad

Avril Caleb
ARC

MADERA

MADERA

AHSAO

UNDP

$\mathrm{NCA}$

GAF

ACBAR

I. Vaccine Prices

VSF had received some information but not DCA or UNDP. It was decided to wait for the remaining information and to put this item on the next agenda.

\section{Newcastle Disease Vaccination}

The only one available in Peshawar is from the VRI and has to be kept at a low temperature (at -20 degrees for 2 years, at 4 degrees for 6 months). If it is kept at a higher temperature for one or two days it is useless. GAF use an icebox in winter as it is possible then. MADERA use a fridge. DCA will stop using this vaccine until they have a cold chain.

It is uncertain which is the vaccine from Peshawar. La Sota? Muktheshwar? The leaflet states intramuscular injections to be given whereas VRI say subcutaneously.

Dosage: first dose: intra ocular to 10-15 days old chicks, second dose: $0.5 \mathrm{ml}$ intramuscular at 4 weeks, third dose: $1 \mathrm{ml}$ intramuscular at 16 weeks.

There are 3 different dosages all in the same bottle with no markings

A different Newcastle Disease vaccine that can be kept for longer is available. The Peshawar one is live, the other "killed". It is easy to keep and provides longer immunity but 2 injections are needed as the first does not provide immunity. It is not so popular in France as each chicken needs to be injected, whereas the other vaccine can be added to water and be sprayed.

There was agreement to try to find the "killed" vaccine and import. It was reported that FAO are using "killed" vaccines and DCA will contact them for details. 
233 


\section{4}

\section{Cold Chain}

It is very expensive to set up a cold chain. DCA reported that a good kerosene fridge has to be imported and costs approximately $\$ 750$. VSF reported that gas is available but gas cylinders have to be imported and they are heavy to transport. VSF has a gas installation - the empty bottles are returned with new ones being taken by lorry. These are large bottles which last 3 to 4 months. Sometimes kerosene is difficult to get inside Afghanistan. For a generator there is the same fuel problem.

IV: Vaccinations

MADERA have produced a booklet for vaccinations as was used in Afghanistan before the war.

MADERA reported that VRI Peshawar have a letter which says that they are not to produce vaccines for any foreign agencies following UNDP's requests for many doses until they have permission from the Federal Government. UNDP reported that they had received a telephone call from the Director of VRI that they cannot supply vaccines. GAF reported a shortage of vaccines in Pakistan and production at Peshawar VRI has now stopped.

UNDP is not able to set up vaccine purchasing arrangements with Quetta because veterinary project proposals are not approved yet and therefore they don't have money. However NGOs need to order vaccines before proposals are accepted by UNDP in February or March. If Peshawar VRI cannot produce vaccines, each agency will have to contact Quetta or Lahore individually which will be extra work. Lahore also have difficulty coping with large orders. MCI are willing to make one joint order from Quetta but want one payment. UNDP wanted standardization but are now hindering this process. Lahore and Peshawar vaccination dosages are the same, Quetta is different. This could cause problems for paravets and vaccinators and many changes are best avoided.

V. Poultry Farming

UNDP is interested in funding but do not yet have a policy for what they will fund.

Before the war more than $85 \%$ of the population were involved in agriculture and always had animals and chickens. It was an important source of income before the war and is again now. One egg costs about 30 afghanis and one chicken 1500 to 2000 afghanis..

ARC have a project in Logar to breed chickens and assist needy families. After one year they will hand the chickens over to the families. It is not for marketing but to assist families. 


\section{5}

SCF(US) have been researching for a proposal. They plan to use Fayomy (Misri or Egyptian) and to take them at about 6 weeks when they will have had their 2nd Newcastle injection but are still small. However, GOP farm policy is to sell at one day old. These chickens will be taken to poor families and the women will be instructed by female staff.

MADERA transported 50 chickens to one farmer. Their aim is to increase egg production. Fertilized eggs will be distributed to other farmers who will raise the chickens. This farmer is responsible for keeping these chickens separate to others. It has yet to be decided whether to sive or sell the fertilized eggs.

Egg production of Fayomy is reported at anything between 80 and 280 eggs per year depending on local conditions and feed. MADERA are testing with local feeding. They bought their chickens 4 months ago when they were 6 weeks. The farmer was trained by a vet who stayed for 2 weeks and returns every 2 to 3 months to check on progress. As yet no eggs have been laid.

VSF have been planning for one year and have built a breeding house for 200 chickens. This has been a difficult process as it is not the traditional method and they had problems with material, insulation and roof. VSF policy is to breed local chickens as they feel other breeds will not do better with local conditions and feed. They plan to produce chickens and then give or sell them. They will produce chickens during the summer, produce eggs in the autumn and will then sell or give the chickens before the winter as it will be too cold in the big house. They have 2 incubators but have not decided whether or not to use them. The experiences of others is that it is not yet possible unless there is expatriate supervision.

DCA reported that they have received requests for incubators or large poultry farms but it seems that anything that is not traditional needs a lot of work. The traditional way is the best to start with.

\section{Next Meeting.}

The next meeting will be held at 8 a.m. on Tuesday January 23 at ACBAR. The following topics will be discussed:

A. Vaccine Prices

B. Haemorrhagic Septicaemia vaccination

C. Bee Keeping

D. Monitoring Experiences 


\title{
236
}

A. C B A R

\section{VETERINARY COORDINATION MEETING}

\author{
MINUTES \\ January 23, 1990
}

\section{Attendance}

$\begin{array}{llll}\text { Dr. M. Mohd Juma Alimy } & \text { ARC } & \text { Dr. Mehraban } & \text { UNDP } \\ \text { Dur Mohammad } & \text { ARC } & \text { Dr. J. Baker } & \text { UNDP } \\ \text { Dr. Farid Ahmad } & \text { ARC } & \text { Gunnar Andersen } & \text { NRC } \\ \text { Dr. Somsore } & \text { DCA } & \text { J.F. Rubin } & \text { VSF } \\ \text { Martin Valks } & \text { DCA } & \text { B. Boseh } & \text { VSF } \\ \text { Gert-Jan Duives } & \text { DCA } & \text { Xavier Bouan } & \text { MADERA } \\ \text { Dr. Mohibuliah Halimi } & \text { DCA } & \text { Dr. Sayed Mohammad GAF } \\ \text { Dr. Sayed Sultan Masood } & \text { DCA } & \text { Mr. A. Wadood } & \text { GAF } \\ \text { Avril Caleb } & \text { ACBAR } & & \end{array}$

\section{Additions to the Agenda}

A. Poultry Farming (Norwegian Relief Committee)

B. Vaccine Supply (MADERA and UNDP letters)

\section{Vaccine Prices}

No information has been received yet.

DCA sent a letter to FAO to ask about the Newcastle Disease Vaccine they use which is not susceptible to temperature changes but have had no reply as yet.

\section{IIl. Poultry Earming}

Norwegian Relief Coinittee (NRC) run a one month (60 hour) training course in Pakistan for Afghans for 20 students.

This covers hygiene, most common diseases, feeding, housing, temperature. Those who have attended the course have been fairly successful in running their own farms. The training is available for anyone who has a plan to establish a farm. For Pakistan a loan basis to start a poultry farm is possible dependent on the size of inputs but repayment is difficult and takes a lot of admin work.

NRC have a small poultry. farm in Logar which they are planning to extend this year. It will be both a production and training unit. They have some experience of transport ( $20 \%$ of chicks died after they took them in at 10 days old), feeding and medication. A lot of equipment is needed. Food can be produced locally but a grinder and many things from Pakistan are needed. Mainly broilers with some layers (Fayomy) are being used. Logar has had problems although it... looked peaceful last year. When a program is started, buildings have to be constructed and this can make you a target for certain groups. NRC will soon have to check the feasibility of this project. 


\section{7}

Before the war there was a big Government poultry farm In Kolangar so it is not untraditional. Extension workers follow up the families supplied.

NRC telephone no. 41129 .

IV. Vaccine Supply

MADERA had distributed their letter about vaccine supply. Peshawar have stoppéd producing vaccines for foreign

agencies. Lahore have a limited supply. Quetta have some vaccines available st short notice but not big quantities.
However, Quetta told UNDP that they could produce large quantities if they are given notice and some payment in advance. UNDP arefprepared to negotiate and had sent a letter to NGOS providing veterinary services cross border requesting them to give information of the amount of vaccines required in March, June and September of this year. UNDP said that it would be easier for them to give the vaccines than to require repayment after receipt. They propose one project proposal which would include vaccines: for all NGOs whether or not their projects are presently funded by UNDP. A proposal for up to $\$ 20,000$ can be signed in Peshawar which would need less time.

It was agreed that. UNDP should try to establish a long-term solution and in the meantime NGOs will try to obtain small amounts of vaccines for present needs. UNDP will negotiate with Quetta. All agencies are to return the sheet detailing number of doses of vaccines they require by Thursday January 25. UNDP will also contact VRIs in Turkey, Iran and possibly India to try to find alternatives if Quetta are not able to supply the required amount.

V. Haemorrhagic Septicaemia vaccination

The VRT booklet recommends that it should be done May/June and November/December, i.e. twice a year. It was reported that the usual times of illness are times of stress such as when the animals start working. It was therefore decided that this should be done one month before the ploughing. Both VSF and GAF reported that there are no reports of haemorrhagic septicaemia in their areas so they do not vaccinate.

VI. Bee Keeping

Bees have been kept in AfEhanistan for many years. The cost of one hive is approximately 20,000 afghanis and a minimum of $20 \mathrm{~kg}$ to $40 \mathrm{~kg}$ per hive is possible, but an experienced keeper can get $100 \mathrm{~kg}$ honey during the year. The major honey producing provinces are Wardak, Logar, Kabul, Paktya, Paktika, and Nangarhar. Many bees have been destroyed during the war (smoke during bombing). In 1989 ARC started a project in Logar. In Chakh they had 20 hives and these have been multiplied to make 38 . In Kolangar they have 2 projects with 75 and 20 hives. They 


\section{8}

plan that each project should have 100 hives. Once these have been multiplied they will be given to needy families who will be trained. Marketing is not a problem. In Logar there is a problem in winter. Previously bees were taken to Jalalabad but this is not possible so ARC have brought their bees to Pakistan. Transportation is rot difficult but it is costly. Keeping bees is quite simple. If no honey is produced, hives can be multiplied twice a year. Khoghiani was mentioned as a possibility for wintering of bees.

One man can look after about 100 hives. Honey is extracted twice a year - when the flowers are finished and before they transport to the warm places.

VSF reported that 2 years ago an expatriate made a survey and found that people in that area knew how to look after bees. However, last winter was severe and bees could not be taken to Jalalabad so many were lost.

A question was asked about possible problems caused by taking in a different variety of bee to the local bee. No-one had any information on this.

\section{Next Meeting} The next meeting will be held at 8 a.m. on Tuesday 6 February
at ACBAR. The agenda will be:

A. Vaccine Prices

B. Monitoring Experiences (to include methods, results, evaluation results)

C. UNDP expectations of monitoring

D. UNDP Final Reporting System 
239 


\section{A C B A R \\ YETERINARY COORDINATION \\ Minutes of the neeting held \\ at 8:00. Tuesday. Sept. 18, 1990 in ACBAR}

\section{Attendants:}

Gert Jan Duives - chairman

Dr.Sanaul Haq Ahmadzai

Dr.Rubin Jean Frangois

Dr.Neil Clesterton

Michael Blackburn

Dr.Sayed Mohammad

Khalil Rahman
DCA

CAS

MSF

COMDEV

COMDEV

GAF

ACBAR
Dr.M.Halimi

Dr. Mohd.Z aher

Dr. Mehraban

Dr.Q.Ahmadi

A. Manan

Dr.Daud Shah
DCA

RONCO

UNDP

ARC

SCA

GAF

\section{I . Announcenents:}

a. VSF announced the decision of its Board of Directors regarding the suspension of its activities. According to it there will be no more expatriates cross boarder and in Peshawar for a while, but the office will not be closed. It will be at the following address:

MSF

Gul Haji Plaza Room \#226

phone: 42352 and 42349

VSF France Fax No. $0033 \quad 7839 \quad 32 \quad 32$

Dr.Jean Frangois Robin as a representative of VSF appreciated the coordination of veterinary services done by involved NGOs and stated that VSF will remain ACBAR member.

b. Gert Jan said that a British doctor named Singleton. wants to know about the number of horses (mules) in Peshawar area. He is planning to establish a clinic for equines. Please contact Tel. 40871 or 45362 if you have accurate information. RONCO promised to próvide some information.

c. Dr.Mehraban of UNDP recently had a trip to Gilgit and visited Agha Khan Rural Support Program (AKRSP) which started in 1973. He was impressed by the program and was very interested in its veterinary services. He went to the villages and talked to the veterinarians. As he said, the program select representatives from over 1,200 villages and train them in animal husbandry and vaccination for a period of one month. Then these trained personnel go to there villages for service. Their salary is paid by farmers. The trained people buy medicine from the program and sell it to the 


\section{1}

farmers. These people come to the program every 3 months to refresh their knowledge. They are also taught how to make and manage silage. Dr.Mehraban added that the program is moving people toward selfreliance. He recommended for the same type of programs for Afghanistan if possible.

\section{Salary structure for veterinary assistants:}

Since lack of university graduate veterinarians is felt by NGOs involved in veterinary services, some veterinary

- assistants have been employed incharge of Veterinary Field Units. These vet. assistants ate generally graduates of the Veterinary High School with a handful experience. Some of them have the studies of two years more in this field. Their salaries are different from one organization to another which sometime causes problems for some NGOs. Therefore, to be in a good coordination mood, members of the coordination meeting suggested the starting monthly salary of $\mathrm{Rs} .3,500$ and the maximum up to Rs.4,000.

III. Discussion over anti-parasitic nedicines by GAF:

GAF said that it is still difficult to get larger amount of Nilzan, a high spectrum anti-parasitic medicine, in the market. Valbazin is the replacement for it. UNDP proposes if some other simple kinds are used instead. For example: Bilevon for liver diseases and tetramisol for roundworms. The information should be shared among the NGOs.

IV. Update on Planning areas:

This subject will be discussed in the next veterinary coordination meeting.

Only VSF's representative, who is leaving for France, stated that VSF plans to stay in Jaghatoo, Wardak. He said for next

spring they want to start activities in Sayed Aabad and
Chuck.

V. Discussion ever the recomnendations of Livestock and Yeterinary Services (Update Agriculture Guideline)

The present standards and recommendations were told to be accepted as general and recommendations on charging and disease and vaccination as annex I and annex II respectively. The completed copy of it will be distributed
along with these minutes.

VI. A special meeting of the $\mathrm{NGOS}$ involved in veterinary services should be held on Hednesday. September 26. 1980 at 8:00an in ACBAR conference roon to discuss the future 


\section{$A C B A B$ \\ YETERINARY COORDINATION}

\section{Agenda for the next neeting which will be held at 8:00an. Hednesday, October 3, 1890 in $A C B A R$}

\section{Announcements}

II. Update on planning areas

\section{III.}

\section{Enclosure:}

Enclosed please find copy of the Guidelines for Livestock and Veterinary Services, which includes recommendations for vaccination and treatment of farm animals (annex I) and recommendations for charging policies (annex II).

NOTE :

COMDEV, an organization doing the veterinary services has recently opened its office. The address is:

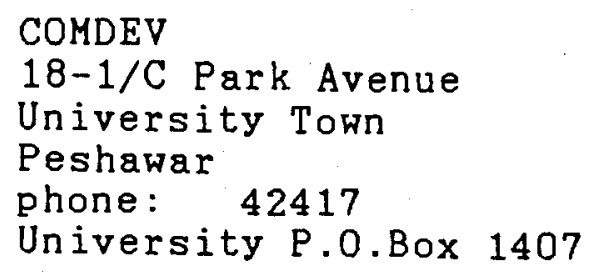


243 


\author{
$A \subset B A R$ \\ VETER INARY COORD INATION \\ Minutes of the meeting held \\ at $8: 00 \mathrm{am}, 0$ ctober 16, 1990 in ACBAR
}

\title{
Attendant5:
}

$\begin{array}{ll}\text { Gert Jan Duives (chair.) } & \text { DCA } \\ \text { Dr. Sayed Mohammad } & \text { GAF } \\ \text { Dr. Daud Shah } & \text { GAF } \\ \text { S.Sultan Masood } & \text { DCA } \\ \text { Dr.Ebrahimy } & \text { UNDP } \\ \text { Neil Chesterton } & \text { CDMDEV } \\ \text { Bert Bosch } & \text { DAI } \\ \text { Gerrit Wassink } & \text { DCA } \\ \text { Q.Ahmadi } & \text { ARC }\end{array}$

Gert Jan Duives (chair.) DCA

Dr. Sayed Mohammad

GAF

DCA

UNDP
COMDEV

DA I

ARC

\author{
Brian Graul \\ Nancy Hatch Dupree \\ Baroukrai Farooq \\ Dr.Ghulam Saeed \\ Michael Biackburn \\ Mohd. Zaher \\ Martin Valks \\ Abdul Manan \\ Khalil Rahman
}

WVI
ARIC
MADERA
MADERA
COMDEV
RONCO
DCA
SCA
ACBAR

1. Announcements:

a. Nancy Hatch Dupree of ARIC thanked those agencies sending their reports to ARIC. She said that ARIC is interested to keep up to date the information provided by organizations. She also requested NGOs to gather information not only about veterinary rather about all aspects of life in the area where they go.

b. DCA and GAF had talked with Bob Eaton of UNDP to investigate the possibility to make a master plan for veterinary work inside Afghanistan. UNDP Peshawar contacted UNDP Afghanistan country office, to discuss possibility for future financing of veterinary projects in Afghanistan. Gert Jan talked to European Economic Community (EEC) to fund some projects, but according to his findings EEC will fund only the organizations have their head offices in European countries.

11. Administrational Experience of NGOs on animals registration:

Almost one year ago the meeting discussed the need for having a registration system for kind and number of animals owned by villagers and kochies. It was decided there, that the NGOS should investigate their own methods. The results were discussed in the present meeting:

- Gaf has distributed a simple one sheet form to animal owners which can be used for one year. It shows the name of the animal owner, province - district - village, kind and

- number of animals, date of treatment/vaccination and name of paravet who applied the medicine.

MADERA and DCA each has provided a booklet which contains inforination similar to GnF. These booklets can be used for 


\section{5}

2 years and look more corifidential.

MADERA has started this system in March 1990 and distrjbuted 6,000 copies of these booklets to the farmers. DCA hus distributeacl about 2,000 of them to Kochies ir Logar and Ghazni.

It was recommended if there is a common and standardized registration form and finally decided that the booklet will be preferable. A group of four people was assigned to work on the format of booklet and bring their product to the next meeting .

TI. Li=t of frivilies provided bX UNDP:

Since the responsible representative of UNDP was not present at the meeting, the subject will be discussed in the next meeting.

IV. Discussion on the diagnostic list of Agalactiae and Rinderpest:

To explain the diagnostic list (procedure) of a olsease in a standardized way, it was said that both diseases should be reviewed once again and will be discussed in the next meting 


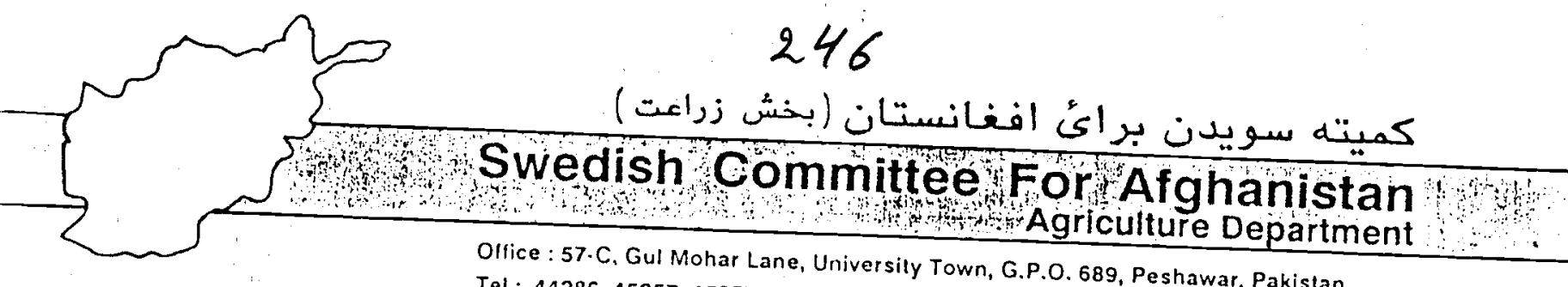

Tel : 44286, 45257, 45357, 42769 Fax: 0521 42519.0 .689 , Pesh

SCA Veterinary section regarding charges of veterinary medicine decided that:

Since SCA has signed agreements with vaccinators, the vaccination and treatment of animals have been free of charge and we stirl continue the same procedure: as well. According to the: SCA decision for the future, SCA procedure will be as follow.

1-All Vaccination should be free to the farmers without any charge. 2-Other medicine of animals should be charged by vaccinators in, the region due to that the farmers will utilized the medicine only for ill and sick animals, not for other. so at least $20 \%$ of rate of medicine should be charged and recorded by the vaccinators, $i *$ it will be the best use of treamnt, and time in region. 
247 


\section{8}

Medicine charges by DCA VFU

The DCA advised the veterinary doctors to charge $50 \%$ of the costs of antiparasitic and other treatments. For vaccination no money is charged.It is now tried out. Both the doctor and farmers recelve a copy of recelpt against charges the money 18 utilized in additional supplies for his next medicine kit. The expertence got by DCA in different provinces are as follows:

1. Baghlan:

The VFU doctior was advieed to charge $50 \%$ cost of anthelmintic and other treatments. From the expected income of Rs. 38604 he returned only 70000 Afs which is equivalent to Rs. 3043. The doctor started charging from the moment he arrived In Baghlan. The doctor explained he was forced by the mujaheedin to give treatments without payment. Further more the farmers were poor.

2. Ghazn1:

Ghazni VFU doctor charged $50 \%$ costs of anthelmintic and other treatments from the beginning of establishment of the clinic. From the expected income Rs.13988 he brought Ro.7652, equivalent to 176000 Afs. Asain the farmers complained about the charging.

3. Parwan(Ghorband):

From the expected income. Rs.45923. the VFU doctor brought Rs.652, but the doctor was not told how much to charge for anthelmintic and other treatments.

Advantages:

The veterinary personnel

can support himaelf in

the future without the

help of any agencies.

2. The farmers w111 only bring their animale if they are really oick.

3. the doctor will take better care of the medjcine.
Dieadvantages:

1. The farmers will reject charsing, if it starts after the second mission pv/vacc. or vet. doctor.

2. The veterinary personnel can be threatened by some ill1terate mujaheodin to treat their animals without charge.

3. It le difficult to avold corruption (e.g. charging without writing recelpt), which can only be controlled by fleld officers. 
249 


\section{0 \\ LIVESIOCK $\triangle N$ ND VETERINARY SERVICES}

"The most important [causes for the decline in livestock are mainly]: the need to sell livestock in order to buy food or raise money for the journey to a refugee camp and the destruction of livestock as a direct effect of war. A further reason may be the effect of animal diseases which are frequently reported by farmers as one of their "biggest farming problems.".

- First Report, Agricultural Survey of Afghanistan

\section{RECOMMENDATIONS}

1. An administrative structure for veterinary services should be established at the provincial district and sub-district levels:

- provincial: central clinic with laboratory facility

- district: vet-administered clinic

- sub-district: veterinary units staffed by paravets, veterinary assistants and vaccinators

2. Training (both initial-vaccinators and paravets-and refresher) courses must be undertaken at all levels within the veterinary structure.,

3. Trained personnel should always work in the field as a part of a structured organization.

4. Veterinary training should give special attention to the nutrition of animals as it is of utmost importance.

5. There should be a methodical recording by the agency of all animals vaccinated or otherwise treated. The owners of animals should also keep a record of the treatment of their stock.

6. For each district a plan should be developed for the vaccination and veterinary care of livestock that observes the recommended disease control calendar.

7. The following infectious diseases should be vaccinated against if possible:

Sheep and goats: $\quad$ Anthrax

Enterotoxemia

Pleuropneumonia

Cattle: Blackleg

Hemorrhagic Septicaemia

Foot and Mouth disease

Horses: Equine Influenza

Poultry: Newćastle disease 
8. Cold chain facilities should be established to ensure the quality of vaccines.

9. Vaccinations should be free of charge. Antiparasitic treatment should be free of charge for a minimum time of one year.

10. For breed improvement, selection of males (by castration of the undesirable ones) and cross-breeding are the most appropriate methods for Afghanistan. Artificial insemination requires highlyqualified persomel and should be considered under appropriate conditions only.

11. Transport of animals:

- whether within a country or between countries should only be done if animals are protected against the major infectious discaises, and have been treated against internal and external parasites.

- should not take place for 7 days after vaccination in order to allow their immunity to build up.

- should allow for a minimum of 10 hours rest every day (24 hours), the rest period being divided into two periods.

- should be done in well-ventilated velicles, with sufficient room for each animal; they should be transported in such a way that physical damage will not occur.

12. There is a need for farm tools-shovels, picks, hoes, wheel barrows. Training in their manufacture should be emphasized over the stockpiling of imports. [There is need for different farm tools in different areas.]

13. Manufacture and use of whe el-borrows should be encouraged.

14. For more complex agricultural equipment, e.g., moldboard plows, critical parts should be manufactured centrally to be delivered to local shops for completion. 
MADERA
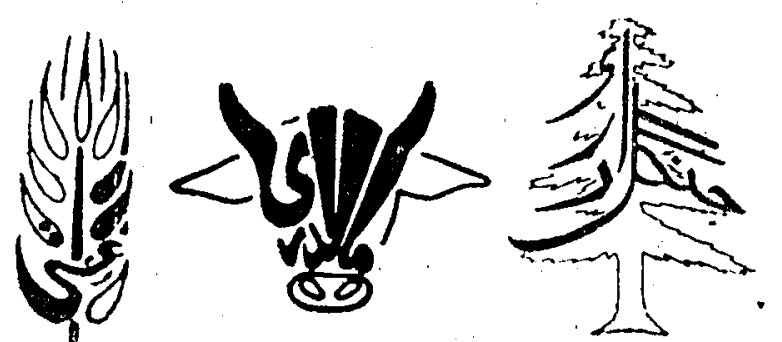

252

Mission d' Aide

an Developpement des Economies Rurales

en Afghanistan

Peshawar, 10.7.90

To: Gert Jan, Chairman of the Veterinary Coordination

From: Olivier, Weygal Project Manager

Subject: MADERA's policy on charging veterinarian medecines

Dear Gert Jan,

As agreed in today's meeting, let you kriow more about our selling policy for vet medecines. The points listed below concern all of our projects, in Kunar and Laghman.

1. The medecines are given free during the 1 st year of a project. In Weygal, our oldest veterinary project, the people have been paying for treatments since 89. In Pech and Laghman, we started to charge in 90.. In Äsmar and Baricot, all medecines are still, given free.

Advantages: smooth start of the project, extension of the services.

Disadvantages: difficulties may arise when shifting from tree distribution to charging.

2. Four ways of propagating medecines are used:

- Vaccines are free, and administrated by project staff during team campaigns. The vaccinated animals are registered, a vaccination note-book is given to each breeder and filled by project staff (sample included).

- Anthelmintics are charged at a very low rate: 1 Afgh/goat or sheep, 4 Afgh/cattle. They are sold by project staff and administred by the farmers after taking advice from project staft. 
253

- Other treatments are sold at subsidised prices ranging from 50 to $100 \%$ of retail price in Pakistan. The breeders can get these medecines from contractual shops, against money and prescriptions given by project staff. the medicines are administrated by the breeders, after taking advice from project staff.

- The clinics are providing medical care free of charge for the animals brought to them.

Advantages: the shop system allow broad selling of medicines without pressions from the breeders to get then free. The vaccination campaigns allow registration of the animals. The clinics provide data on local diseases.

Disadvantages: the main one is related to the administering of. medicines by the breeders themselves: misdosages, etc, may arise. We are developing awareness material for each kind of medicine and stressing education af the breeders by project
staff.

I hop this is enough. I cannot attend the neat meeting, but I would he glad io attend regaling afterwarch.

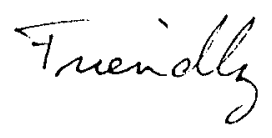

Olivier 
Recommendation on vaccination/treatments of farm animals in afghanistan.

Notes:-1. Enterotoxemia vaccination

-only if Enteratoxemia is present, before lambing and in autumn before going into stable.

-revaccinate after 1 manth

-vaccinate lambs over 3 months of age.

- vaccinate all adult pregnant ewes.

-immunity lasts 6 mon'tis

2. Hemorrhagic septicemia

-twice a year before the plowing season

-be careful in pregriant cows, vaccination after 8 th months pregnancy may induce abortion.

-milk. reducition almost always accurs for 5-6 days.

-immunity lasts 6 months

3. N.C.D.

- live vaccine requires refrigeration

- eye drop by 2 weeks of age and $i . m$. injection at 4 and 16 weeks. A practical solution would be: two vaccinations with one month in between in the beginning of the year and after that, revaccination every 6 months.

\section{Deworming}

-against intestinal parasites: twice a year. If liverfluke is present, deworming against this parasite should be done at least once a year.

-especially in sheep and young cattle.

\section{Anthrax} -especially sheep. Cattle only if the disease is seen
in this species.

-in rare occasions, anthrax occurs as a result of vaccination, this can be treated with penicillin -don't give antibiotics to an animal that has received an anthrax vaccination within the past seven days, while it will obviate the effect of the vaccine.

-don't vaccinate goats, sheep and cows at the end of pregnancy, while it can cause abortion.

-immunity lasts 6 months.

\section{Foot and Mouth disease}

-vaccine requires refrigeration.

- vaccinate all cattle twice a year

- if outbreak occurs, vaccination of the surrounding

$\checkmark$ illages should be carried out immediately

- the FMD types Asia $1, A, C$ and 0 were present in the past in Afghanistan. If FMD occurs, samples should be taken to specify the type. 
7. Vaccines for blackleg. Anthrax, HS and Enterotoxemia should always be kept in a cool, dry, dark place. They will then retain efficacy for up to 6 months ( Anthrax for one year). CCPP, Sheeppox, FMD and NCD vaccines require refrigeration.

If the temperature goes below $O C$ in wintertime, the vaccines should be kept in isolated boxes to prevent freezing.

8. Vaccinate only visibly healthy animals.

9. Never give different vaccines with the same syringe/needle without previous cleaning.

10. Never give two concurrent vaccinations/injection's in the same spot on the animal.

12. Vaccines require a certain period (usually 1-2 weeks) in which to build sufficient immunity in an animal.

13. Practice cleanliness when handling/storing syringes and needles. After use, clean with water ( and 'flush through needles), then boil in water for 10 minutes before starage, keep needles sharp.

14. General schedule for the application of vaccines and deworming:

- In spring(march/april): Anthrax, Enterotoxemia, Hemorrhagic Septicaemia, Blackquarter, deworming.

- In autumn (august/september/octaber): Anthrax, Enterotoxemia, Hemorrhagic Septicaemia, deworming. 


\section{Contagious Capine Pleurnpaeummia (CCIP) \\ (Mycoplasma mycoides Subspecies Mycoites)}

\section{6}

Animals description:

A History

Goats of all ages can be affected, great incidence of the disease is in the winter time.

Anamnisis:

Loss of condition, weakness, Copious Nasal Discharge, Cough and loss of appetite.

Morbidity from $60 \%$ up to $100 \%$ and mortality Ranges up to $70 \%$ if not treated.

ismainily by aerosol.

B Generai Inspection:

Animals are weak, emaciated, cough, copious nasal discharge, signs of pneumonia are evident. Animals are standing with head down and open forelambs showing defficult breathing. Animals stay behind the flock, lie down and are not likely to move. DuIl and irregular coat is also evident.

Ereathing is shallow with increased frequency. Pulse frequency is increased, too.

Temperature ranges between $40.5 c^{\circ}-41.5 c^{\circ}$.

Lab Diagnosis:

Specimen of thoracal fluid for dark ground microscopy is necessary. Tissue of lungs requires refrigeration after collection and then can be sent to the lab.

D Diagriosis:

F bifferntiel Diagnosis:

For clinical signs see Anamnesis, and General inspection. Post-mortem finding: Excess of straw-colored fluid in the thoracal and percadial cavities, consolidated lung is usually covered with spangy fibrin, pleuritis with deposit of fibrin on the pleura, pea-sized yellow nodules throughout the lungs parenchym, destension of interlobular septa with fluid, variation in color of the lobules accordi to the stage of consolidation, and typical murble like structure of consolidated Jungs on the incision.

Chlamydiosis, verminous pneomonia, and atypical pneomonia. 
257

† 
Beport of fleld vielt to achlo and Bodat diatricto
Nangarhar province from April 1.4-17, 1990

\section{Background}

This join investigation trip by UNDP, DCA and CAS was organised by UNDP. With the cooperation of UNOCA. Team leader was Dr. Meh-
raban.

the purpose of the misslon was to investigate the reported outbreak of Rinderpest in Achin district of Nangarhar and which was April 10th 1990 .

the investigation was carried out by interviewing livestock owners, examination of the slck animals and outopsy of a dead
calf.

\section{Conclusion:}

1. About 10 cattle died in investigated area from unknown dis-
ease.

2. It is highly unlikely that the Rinderpest is present in the a. The diseases were sporadic and non contagions.

b. All animals died showed symptoms different from each c. Morbidity rate was very low and the mortality rate was
almost $100 \%$.

3. The calves which showed nasal discharge with high fever could be preumonia or verminous pneumonia becalise the dis-
ease was prologned about $10-15$ days. 4. Newcastle disease, endoparasites and ectoparasites, plant
Intoxication, foot and mouth disease, sheep and goats pox,
cow pox, interotoxaemla, pula

according to the symptoms pullorum and passibly brucellosis present.

described by the farmers were

Recommendation

1. No further action concerning alleged Rinderpest outbreak re-
quired..

2. Newcastle disease vaccination and deworming of large and small animals should be given priority because all viliagers complalned from huge losses of their poultry population, and losses of welght and death of cattle and sheep due to. the
heavy infestation of endoparagltes. 
3. Enterotoxaemia should be further investigated and the vaccination should be carried out in the area because some of the symptoms in sheep and,goats described by the villagers
seems to be enterotoxamia.

4. Since the life of all villagers are mostly depend upon their livestocks, provision of the veterinary health care for these areas could play a significant rule in their life.

5. It will be wise to established the DCA planned veterinary field unit in saray village, of kot valley, Rodat district which is the beggist and accessable village for the rest of planned for a big number of livestock lnstead of the one easily.

1 Achin District

\section{Details of Findings.}

\subsection{Maruf China:}

A shepherd while grazing 100-150 sheep complaining from liver fluck and lung worms in his flock and aware of sudden death of cattles in Basawal and Arzanaw of Momandara district.

\subsection{Chalgazi:}

The interview was held in a mosque after the zohar prayers where most of the elders were present.

The total number of cattle was 600 in the village from which 5 were died. Cold mouth, clenching Jaw, diarrhea avoiding taking feed and colaps before slaughtering were the clinlcal signs. The duration of the clinical slgns was 2-3 days and one of them carried the disease for 10 days. Postmortem signs of these animals as descrlbed were different. Some of them had enlargement of glabladder. others showed blood clots in rumen. The meat had bad taste and odder.

One of the cow had constipation and then bloody diarrhea recovered after treatement with 4 million units of penclilin.

New. castle disease (Toghakay) was descrlbed which occured once or twice a your. Mortality is $100 \%$ and mor-
bidity is $90 \%$.

Two calves were slck for 10-15 days had high fever ( 40 centlgrade) Increased resplratory rate and pusy dycharge from the nose were injected terramycine LA
intramascularly. 


\subsection{Hojam Kala:}

\section{0}

Interview was : held with the owners of the animals. There are 100 cattle in this village from which one bull is slaughtered before daying and a cow was died.

clinical signs were bleeding from the nose, lameness and collaps within 12 hours.

Five goats died in this village showing diarrhea, nervous symptoms, specialiy well conditioned animals. All of them were eladghtered before daylng. Enlargement of the gall bladder, intestinal haemorrhage and presence of yeilowish fluld. in perlcardium were the postmortem signs. Other diseases like foot and mouth disease, pullorum and Newcastle are the major problem of the village.

1.4 Kahi Bazar

The people were asked if the animals died or diseased in the area. One cow aborted 6 month calves for 3 consequence times. It showed symptoms of lameness. The farmer was asked if the milk sample could be taken for the diagnose of brucelingls, but the animal was not avallable at home. From the interview it was known that some animals are died in Matan, shadal and Trelay
vilages.

.1 .5 Trelay:

A dead claf was found beside the road. The owner of the anlmal sald that the anlmal had miled typany in the evening and was found dead in the morning with a ilttle
blood came out of the anus.

The animal autopsied (see annex 1). It was found that the animal was died from tympany, although the liverfluck signs were present in the liver. I samples from lung and liver were taken for the laboratory diag-

Ectoparasites in sheep and goats and New castle disease

1.6 Achin Kalay

There are 300 families living in this village. Every family has $1-2$ cows. And the begglst farmer has up to
12 sheep or goats.

No cattle was died recently. The major complain was Erom dyling newborn lambs of 5-6 days age showing diarrhea at the early spring. Newcastle disease (Toghakay)
is the major problem in poultry. 
This village has about 50 families. The total number of cattle is about 200-300, sheep, 80 .

No cattle was died recently. 4-5 sheep suddenly died without clinical symptoms. It was taught that it could be due to the toxic effect of plants, like Augai gul, Torapana, and Morghai Pal (the samples are brought for plantology investigation). Some animals were'cashexic and had cough.

\section{2 Shashkhail}

This village has 100-1500 cattles', 200-300 sheep, 'some turkeys and a lot of chicken. No cattle was died recently. Major problem was Newcastle disease and liverfluck in sheep.

\section{3 Bandokalay:}

There are 40 families having 1,50-200 cattle and 140 sheep in this village. A number,be newborn calves died showing symptoms of diarrhea.' Most of the sheep slaughtered in this village had cyst in lungs and liver, and worms were present in the lungs. There was a huge loss of poultry due to the Newcastle disease.

\section{4 Saray:}

The interview was held in a blg crowd of villagers. The number of family presnet sald to be 20,000. All of them ralsing $1-6$ cattle. An oxen was slaughtered by farmers before dying had naematuria. Blood clots in the rumen and cyst were found in liver and lungs.

One of the farmers having 40 sheep complained that 30 sheep were diseased from whch 4 are died. The showed pussy discharge from the nose and dlarrhea, swollen liver and congestive lungs were found after slaughtering. Most of the farmers complained from the presence of
papulfesictes on the face udder, halrless parts of the body
as well as well as on the whole body in cattle and speep. These vesicles were ruptured and discharged watery flulas. Newcastle disease (Toghakay) was frequently occurred and the losses due to this disease were ihuge. Cashexie in cattle was also complained by the villagers.

Dr. A.B. Mehraban, UNDP/OPS

Dr. M. Hallml,DCA/VTCSD

Dr. Sana-ul-Haq Ahmadzal, CAS 


\section{2}

V.S.F. page 1

TENDTSMICS DISTSASES IN JBGIUTU WARDAR

\section{INTTRNAL PARASITILSM}

Helinfintine : lunpwarms integtinal warms

Lever flugs : fasciola hepatica in a huge scale ( a lot of. Limnea Truncatula can be found in the brooks: may be one hundred in square meter)

They are the couse of an important morbidity,' of lot of casea of necrotic hepatitis, of important rate of enterotoxemia.

They are also the cause of a blg lack in lever coneummation ( it is really a plty in a place $\therefore$ where meat 1.6 rare).

KXTTTRNAT PARASITISM $\because \cdots$

Very acute in winter on cattle, sheeps and goats

GINITAL DISTASES

Metritis, retained placenta and repeat breeding on female, bad complications of blood method castration for male.

\section{DISGTAST OF I.OCOMOTION SYSTKM}

$40 \%$ of cases are problems with sabots ( most of the time a good cutting is enough but not very easy to learn to nurses even to do ourself).

$30 \%$ are due to nutritional pathology some cows are so week that they are not able to move.

$20 \%$ are due to real arthritis and can only be treated with antilnflamatory.

$10 \%$ of vartous cases: - pre or post partum sickness ( lack of phosphorue)

- accidents : fracture, luxation, 


\section{3 \\ V.S.F. page 2}

NUTRITTONAL DISFASTS

Very important last winter. ( it was the colder one oince the
beglnning of the war)

There are two aspects of them :

- Deficiency diseage日

We found that rations are quite good (wel1 balanced) but are catastrophics regarding to $\mathrm{Ca} / \mathrm{P}$ ratio (which is around 10 ), that s why we gell phosblocks and oubsidize cotton serd
cake market at half price.

- digertive rathologie :

The main aspect of it is rumen disorder with inrumination (about $30 \%$ of the pathologie last winter).

That fact can be linked with the destruction of kareser: in the areas where kareseg have been destroy farmers build some pools, these pools contains very cold water and they froze. during the night, drinking that water block the rumen and increase flug infertation.

An other fact is that animals don't drink enough water (10 to 20 11ters by day), the conseguence of that is a rumina 1 contenta very dry and hard (1ike papier maché when listening

We observed also some case of forelgn body on oxen and cows (some with pericardite), some cases of colics on horser.

\section{VARIOUS DISEASTSS}

- Strangles on donkeys ?

- Spring asthme on horges

- Papular atomatitio of cattle.

- Contaglous echtyma on sheeps 
UNITED NATIONS DEVELOPMENT PROGRAMME

OFFICE FOR PROJECT SERVICES AFGHANISTAN PROJIECTS OFFICE

P.O. Box 776, 4th Floor, Gul Haji Plaza, damrud Road. Peshawar, PAKISTAN

The Chairman

Dated: 07 June 1990

Veterinary subcomittee ACBAR

Dear sir,

I refer to a letter from varlous Afghan veterinarians dated 31.5 .90
and copied to ACBAR.

As the veterinarians have elected to remain anonymous and with no address I can only send my reply to you'for.dissemination.

1. I am grateful for the dissertation on Afghan agriculture and animal husbandry though I am uncertain as to the point of it.

2. In para 5 of page 1 it is suggested that koochi find it difficult to move around any more and yet NGO reports indicate they are still moving in their thousands and very much as in the past. There appears to be a difference of opinion between the veterinarians and the NGOs they work: for.

3. Para 6 of page 1 is a political statement and $I$ will only respond on technical matters.

4. Re para 1 of page 2, Russia has in fact supplied large quantities Mazar.

5. The balance of page 2 is agreed to except the statement in subpara 9 of para 4. In fact there is a lot of animal trade going on between country and city. If there were not how could there have been 90 head of cattle and camel slaughtered in Kabul vlaughterhouse in one day. That was not prearranged as the The Northern cities of Herat and Mazar had plenty of meat available at
the time of my visits.

In para 1 of page 3 the statement that the UNDP : office closed its projects is untrue." The veterinary faculty budget from UNDb/FAo was been provided by then. most of the infrastructure for the Faculty had indefinitely. The Afghan Government was to do that. 
The "illiterate farmers" mentioned in para 2 are the some people from. among whom DCA and GAF recruit paravets and vaccinators for training. Will they be illiterate simply because they are over military service age. I suggest that age and experience with livestock will make them better candidates than many who are trained in peshawar. Is age and experience not respected in Afghanistan.

The comments in para 3 are again political but I Eind it hard to reconcile the suggestion that assisting farmers by supporting veterinary clinics is collaboration but assisting veterinarians by supporting the veterinary faculty is acceptable.

In reply to the first series of question:-

1\&2. 230 veterinarians and paravets are said to be currently employed by V.S.D. This could only be partially verified at the 10 clinics visited.

3. There are limited facilities 'for practical experience available at the Duralaman clinic run by the Faculty.

4. Various visiting scholarships were made available to faculty stafe members by UNDP/FAO but they have all been completed. No further scholarships are planned.

5. Many of the teaching staff of the faculty and some CVI stafe members failed to return to Afghanistan after their overseas visits. This failure to honour their obligations to UNDP/FAO and Afghanistan does not encourage donors to offer further training scholarships. It is not known how many staff members left the country voluntarily.

Establishment of clinics

1. The $\$ 6,000,000$ is in fact for $40 \mathrm{clinics}$ and 30 field units for 3 years as explained at the $\triangle C B A R$ meeting

Annual average cost of a cross border clinic is $\$ 35,000 \mathrm{Rs}, 740,000$ Annual average cost of a project clinic will be $\$ 28,500, \mathrm{Rs} .610,000$

2. Cross border clinics serve 30-40,000 sheep and goats 4,000 cattle

3. There were a total of 79 clinics operating prewar. 
4. No new clinics have been opened recently. Some pre-existing ones are reported to have been destroyed by Mujahiden actions. It is known that men over military conscription age can enter the
government held towns and cities freely.

5. How can $\Lambda$ fghan citizens have international immunity. Why would
Afghans not want to be $\mathrm{Afghans.}$. What

Pastures etc.

1. This question is totally irrelevant.

2. This. question is unwortby of qualified veterinarians who should feed them. Afghan owners will not keep animals if they' cannot

3. Yes there is good grass mainly because animal numbers are reduced. Prewar there was too much overgrazing of pastures.

4. If one goes to Afghanistan one finds that transhumant movements of herders with their. livestock, in the Northern areas espe-
cially, are just as they always were. provision of veterinary services.

The conclusions are political.

\section{Proposals.}

1. No students were forced to leave Kabul. Those who left made their own choice and they can return to kabul to resume their tan is unlikely to fund another one veterinary faculty in Afghanisside the country.

2. There is no compulsion on UNDP to do any thing for veterinarians
or veterinary students.

3. Badgis is one of the provinces to be helped by the proposed project. Other remote northern provinces not able to be serviced
from Peshawar. will also be assisted.

4. If NGOs are willing to employ veterinarians using unDP funds they will give refresher training. UNDP will not Eund training for
veterinarians who cannot obtain employment. 
UNITED NATIONS

Sheet No.

Development Programme

267

5. Veterinary clinics will be started all over Afghanistan as and when management, staff and funds are available. It should be remembered that in some provinces already, as a result of aGo and UNDP intervention, veterinary services are better supplied than they ever were prewar.

It should also be borne in mind that comprehensive countrywide veterinary services cannot be provided in a country torn by civil war.

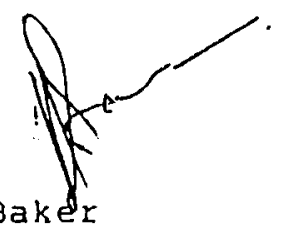

Jock 'Baker

Acting Deputy Programme Manager

UNDP/OPS, Peshawar

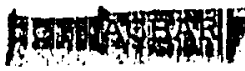

j1b9002 


\section{8}

ACBAR MEMURANOUM

Date: ' October 12, 1989

To: NGOs involved in Veterinary Operations inside Afghanistan

From: $\quad$ Avril Caleb

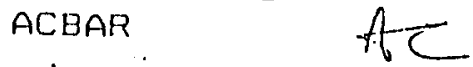
Subjert: Meeting of NGOs involved in veterinary Operatims
inside Afghanistan Ericlosed please find a copy of notes from the last menting of
Veterinary NGOs held on October 4,1989 at ACBAR.

Please note that the next meeting of this group will be lield at

$8 \mathrm{a} . \mathrm{m}$. on wednesday Detober 18 , jgag, again at ncibar. 
269 


\section{0}

Watters arising from ACEAR meeting af NGOs providing Volarimary Services to. Afghanistan Ath Detalier 1989 and bribgti up in replies to the UNDP Questionnare an Veterinary activitides.

UNDP in particular is grateful for the higl level of attondance at the meting and for the interest ghown in the reconstiuction of veterjnary and Animal. Hsbandry Gervices in Afghanistan.

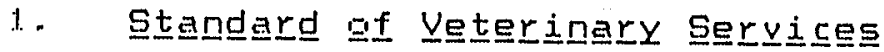

The level af vele inery gervices to be pravided far Afghanistan.wild require further discussion.

There appears to be majority opinian that a, systen that provides veterinary gradbates at Provineial lovel and trained paravets,

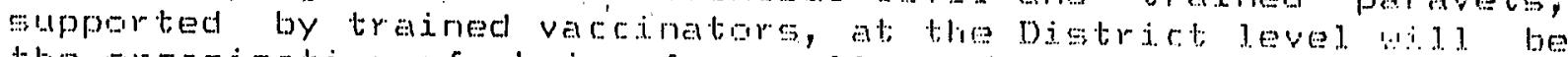

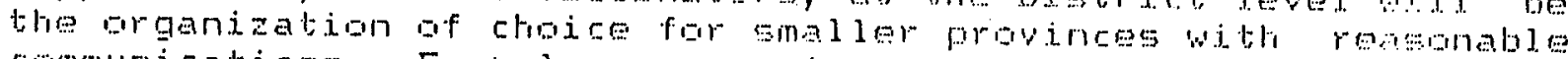
communicatians. For larger provinces with less commujeations veterinary gradiates may be required at the District level.

$\Rightarrow \quad$ auestion:

Are Provinees and pistricts viable political. Units at present ar slibld some other systan at boundaries be used. Commander areas?

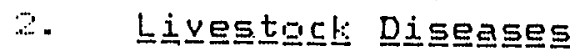

There appears bo be agreenent that the major coriditions affecting livestocte, in wrder af economic importance, are:-

Priority 1. Antirax

Bla a cloquateter

Enterg toxidia

Internal parasitism

New Cagtle Disease.

Prigrity 2. Contagiols Agolactia 6 in some areaso

Hemor rtagic Spetidicamia

Fout and Minth Disease

Contagious Caprine Pleura Pneumgnia

Contagious Erivino

Extermal. Faragitisn

Vaccines requiring cold chain starage are foing bo bo difficul to pravide other than in small, easily accessible,

Can any information regarding new vaceines, vaceination. methods or sources gf vaccine be pouled far the infoination af all NGO $?$ 
There is litile agreement an the need tig lave livestocl: owners. pay for vaccines, medicines of services, now or in gome time in the future. This will reguire further thouglit: and discussion at a later meeting ?

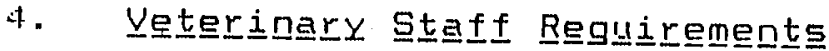

There appears to be little definite information at present as bo the availability af. Afghan Veterinary gradutes

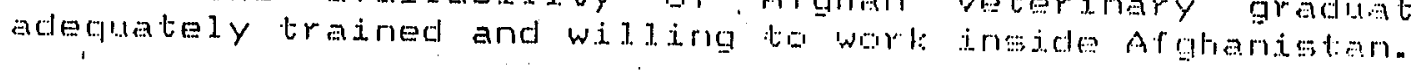

At the same time the future regurements, and employment Gportunities, for DCA \& GAF tratied parawets and vaccinators are uncertain.

The level af training given to para-vets and vaccinators at the twa training 56 thols also appeses to barrant ciscussion as it will have a direct effect on the stariart af service to be provided, discussed in iben 1 aboue.

\section{Norttegrn Prouing드}

There are obving difficuldes in providing veterinary

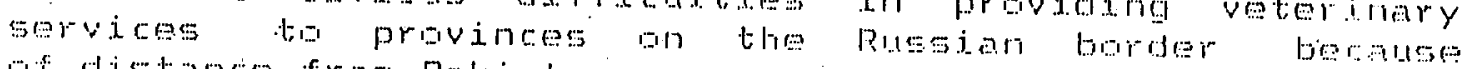
wif cistiance from patistian.

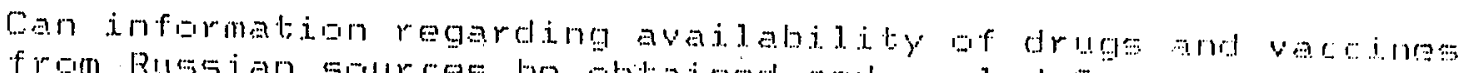

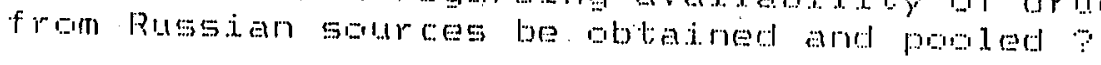

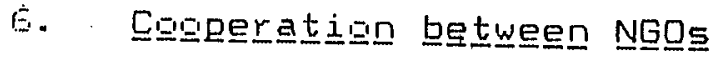

Proling af ifformation regarding animal diseasos

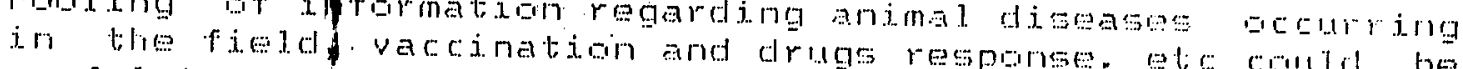

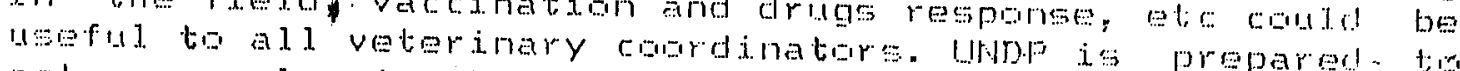

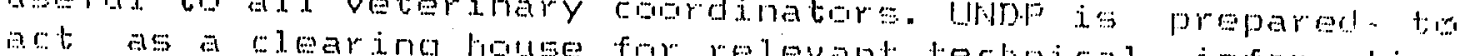

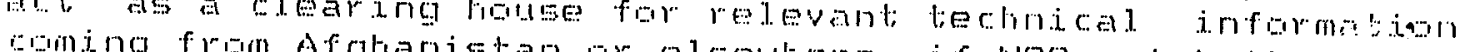

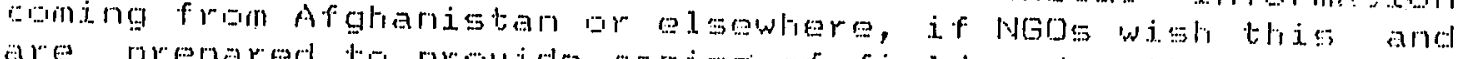
are prepared to provide copies of field and otier repres for collation and general djusemination.

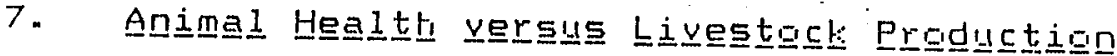

Majority opinjun is that with" limited resources avaid abe

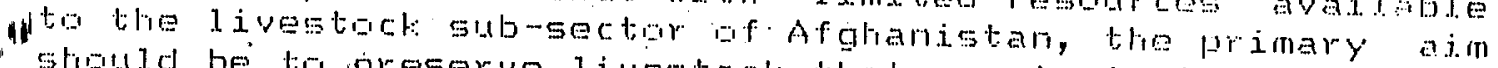
flowde be to preserve livestock bhat remein in the depleted. care. and herds througti the provision of adoquate horlit.

Natural regeneration will wecur over time and very listile can be dine, given the magnibude af etoct losses die to bar,
to hasten that regeneration. 


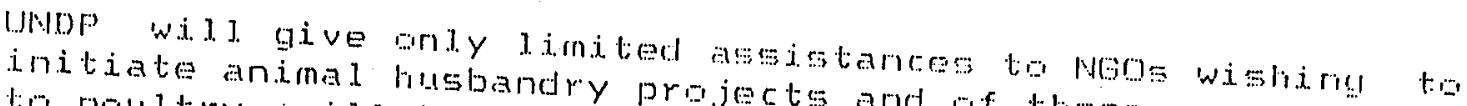
initiate animal husbandry projects and of these, any rol abod lo poultry, will be given priority.

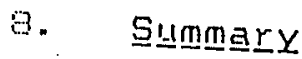

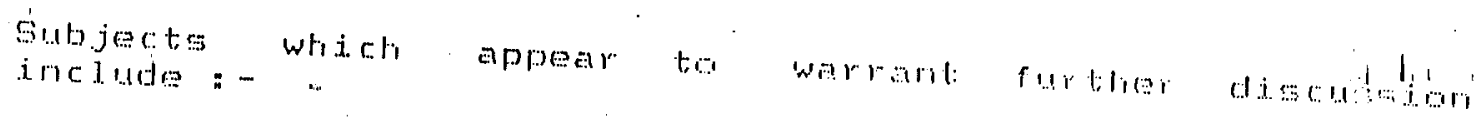

Siandard of veterinary services

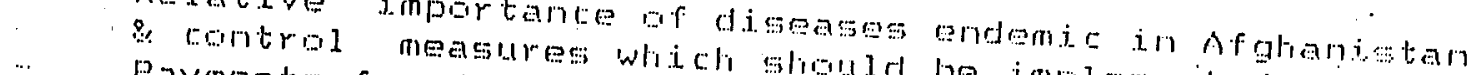

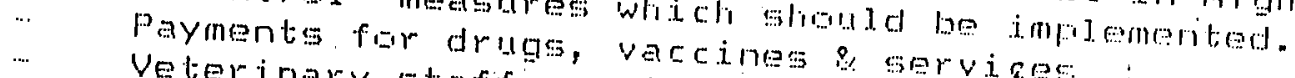

- Veterinary staff requirement servines

- Cogperatjon between NGos.

There was general

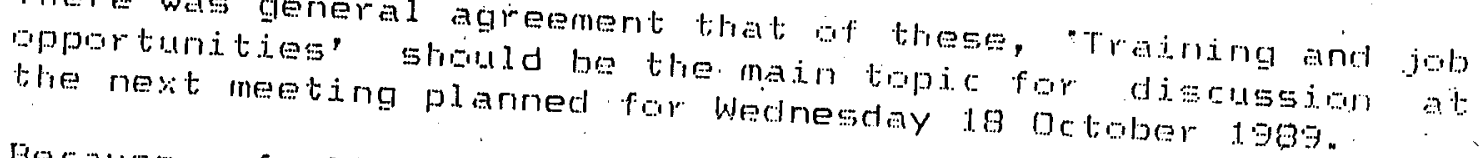

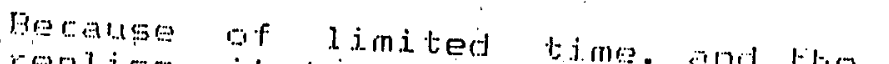

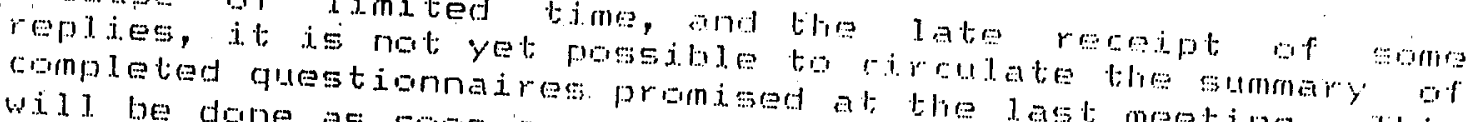

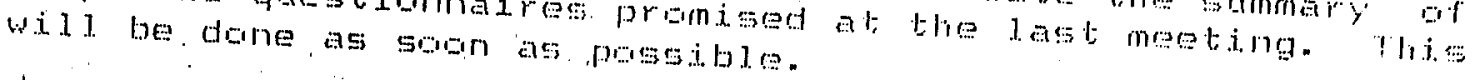


BOE EATON

DR. MARTIN VALKS

MAGOOI. GHELWATY

DR. GAYED WOHAMMAD

DOUGLAS SALTMARSHE

MOHAMMAD MODSA MASODY

TORE TORN PETIERSGON

WIM EAKKER

PETER CR TCHTON

HAM DUUL LAN

JIEFF: I... TVERMAN

KHAWA JA MOHAMMAD

DR. RIIETN JEAN FRANCOTS

XAVIER EOUAN

PAIJL HETNZEN

TESHOMIE I_EMMVA

NOOR SHARTF

DUR MOINAMMAD

DR. ATTAUL, L.AH

DP. NOOR-AL - ZALAM

A. R. GAFOORI.

J L BAKER
WNOF

DEN

I)

GAF

ST:

$\operatorname{TPC}$

$\sin$

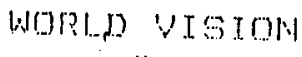

"

AFGHANATD

SNT

NCA

VGF=

MADERA

CRB

ARC

APC

ARO

MEW. WARTS BAGH/LNNIC:?

POH KSUD "WTUERKAGHAR"

EAF

INDFW 
VETERINARY COORDINATION HELIIH:

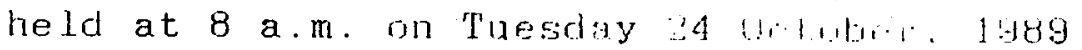
at ACBAR

Should NGOs charge for treatment and how much

Different NGOs use different methods and they whlainfid these as tollows:

A. MADFRA ask for $25 \%$ of the priro of marlinille: with

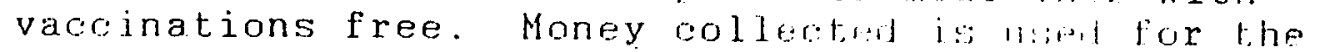
village community, eg. improvement. of momga, etr. Money is otherwise collerted thromul! fin and arivate donations. 'They consider it best mil trim involved in the money side - that should be thre 1.ommin.t.y.

They were asked why the money should nol fi used lor. further medicines and replied that it is lificult for. the vaccinators to ask the people for morr.y for drenching. Maybe later this will br profible.

B. DCA keep a record of work. If they fill. 11.11.0 d large Eroup, then they will charge for vaninalinns - about

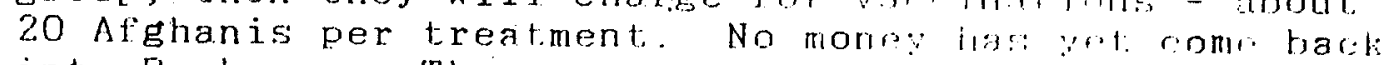
into Peshawar. They may way some ril the wherinary staff salaries from money collected.

C. GAF give everything free of charge. INH(1: is againsty NGOs charging for fertilizer and sul aril tie donor position

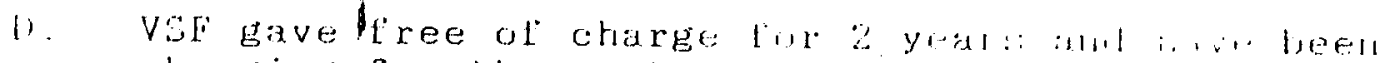
charging for the past year. They l.riod 1 rharge in the second year but it dirl not work. 'l'iffl in the third vear the VSF representative stayel for $b$ minths in the areil. There were no stocke; for 2 monthilin people were told that they had taken too mir.h :., mo more would be provided. When new stroks arriver bil. a acopterl this: new policy of payment.

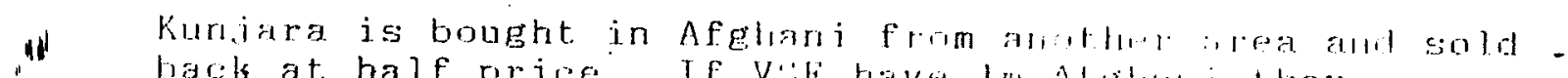

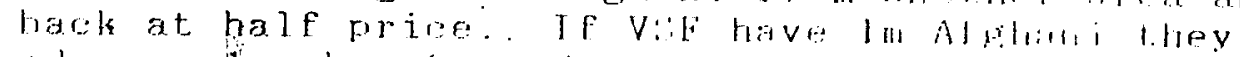

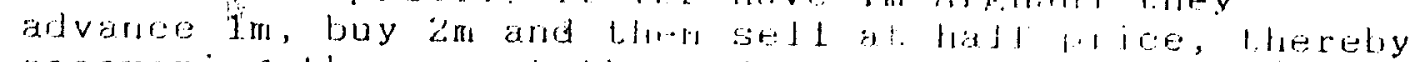
recovering the amount they atvanchl. 'll, linblem is that the rate for the Afghani is olanging all thr time. Poor people are asked to pive what t.1.y $\cdots, 1$ at ford and five produce instead of noney. Thal a prico levels to make sure that people lo mal, , lor mro - than they need.

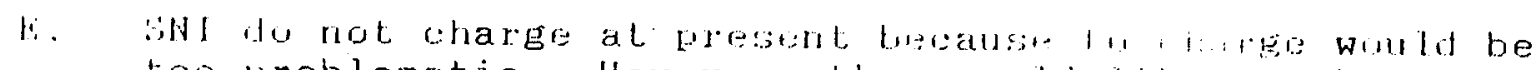
too problematio. However, they woll il il: tor charef. unce they have a structure in place linil l.he: conlidence of the people should be fis imit hy results lrow their work.' Then a rominal ter vally lis froll region to region and taking inta arumul linnsortation costs would be considered. 
other views explessml wele:

\section{5}

F. A priliry ic nreded but there will be many problems. nut.:1, ly:

1. A vel; l, loe checking system will be needed.

2. Considmation mut be given to who will collect the milloy.

3. Peoplo will think that the charges are for the persum allarling rather than for an organ i $\because \mathrm{at}$ în.

4. L'revinl: I Lle Guvernment did not charge For veloriany arvioss so people are not used to pay illi.

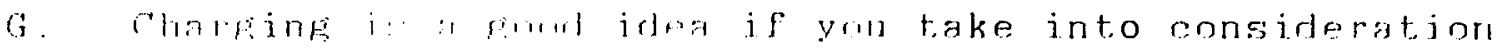
whellier u mal purple uan pay, and if so, how mush. A prst: ible Hi ilurl lin chargjng could be that people whr

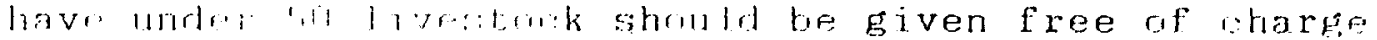
and thuse with more than 50 should be charged.

H. The UNDE L

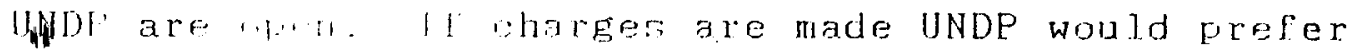

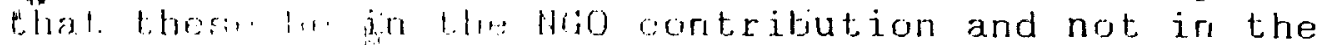
INI) final...l parl. lltherwise an accolunting system nould be 11 . ssary and might become very complicated. For axampl. if the eharge was to be $10 \%$, then that $10 \%$ should be $1 \cdots$, as the NGO contribution and the NGO would then be rulnmille ta recover that money. However it was pointhe wit lhat. to do this would be diffionlt for the loll lowing reasone; :

1. Inflat $i$, wj 11 cause problems when calculating $a$

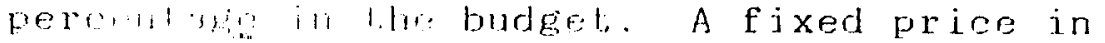

Afghilis mearis a decreasing number of rupees. One suggostin was that salaries could be paid with that mung and then the rupees budgeted for the

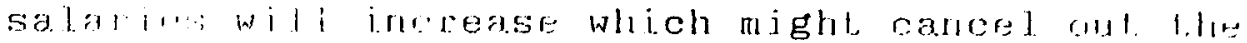
los: in thre rerreasing rate for the afghari.

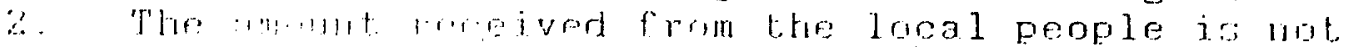

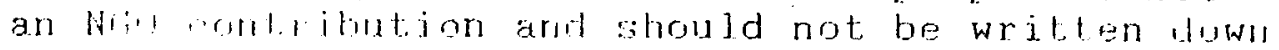
a.s

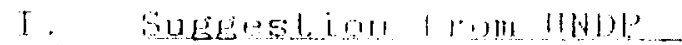

Propusals : ande atales that in the initial stages of a project, ollaris will wot be made for at least 12 months and then whatidation will be given to oharging for sir.

J. Thero was; andment that:

1. Polinin will need to be different from one area to amul.her.

2. A strmature should be in place and people's onfinforme won bolore obarging takes place. 
ri. How much shrul Nug pay tor the field vet personnel

A. Salaries lat a

Average (rupees)

MADERA ( 1989 rate

to be increased

( rupeesi)

$V S F(W a r d a k)$

(dighanisis)

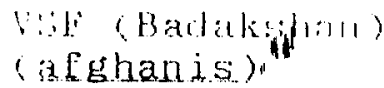

IALl' ( 1 YBS rit

increase plarmed)

(rupees)

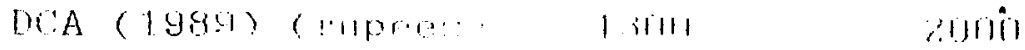

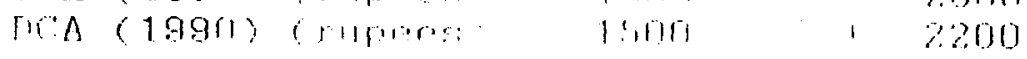

$\because 111111 \quad 2 \div 1000$

$1+1111111$

Mate R!olus

\begin{tabular}{|c|c|}
\hline 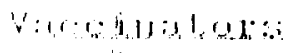 & 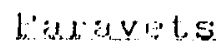 \\
\hline (rome & 2.500 \\
\hline 15010 & 2000 \\
\hline
\end{tabular}

4500

5600 (avorage)

7000

VSF rhent ru l.'

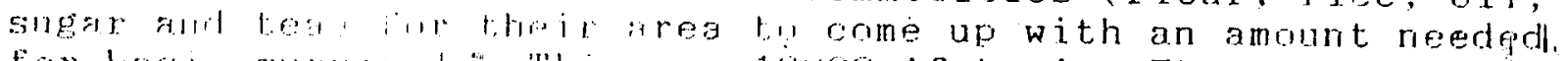

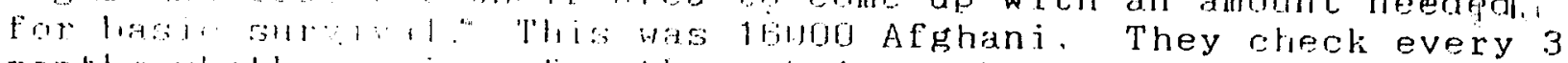

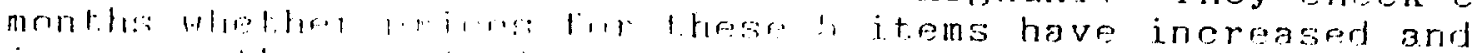

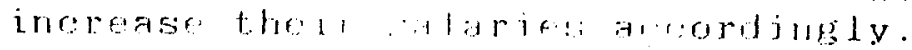

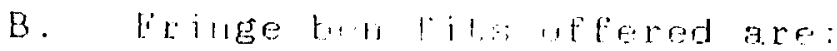

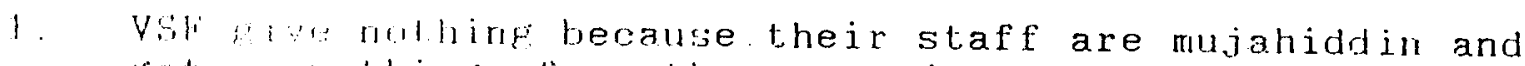
Lel wibly things liom the commanders.

2. DCA the vel gets a sleeping bag. All staff get barl larka lor carrying things.

$\therefore$ SNI give a pall of boots and sleeping bag.

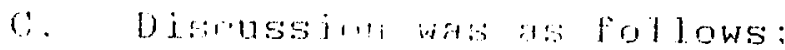

UNDP askarl if "als will go fry the salaries quoted. If not, then a higher a lis i nerded rr veterinary staff wi]l go elsewher:

The $\mathrm{HGOS}$ resprinat wis:

1. A himh alary wil give unfair expectations and othr. akj]l.od staff (e.g. doctors, engineers) will also aport high salaries.

2 A parpht ha: only 6 mirnths training.

3. Sating romptil ion among the NGOs is not gond and a sal lisy sula should be agreed on.

4. Som. "umprisus were drawn with the pay soales

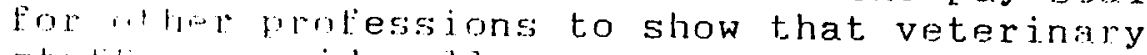
stall are paid we]l.

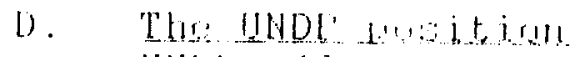

UNHW will heriving a lot of money for medicines,

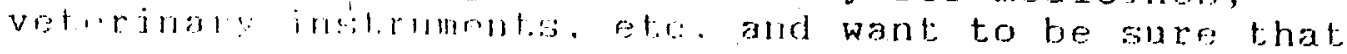




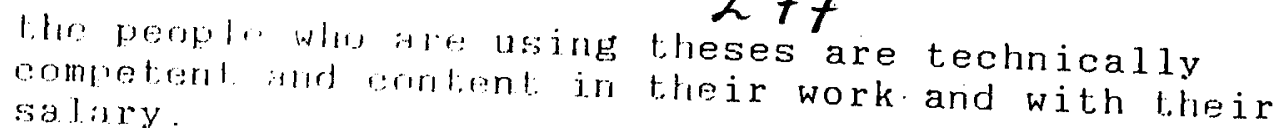
salis ry.

For IND) 1. Hand there has lo be some sort of uniform saliry in throf is a large difference from one adding a oul ul living will need to be done by galaries anmot ys ry with a justification, but for UNDP funding.

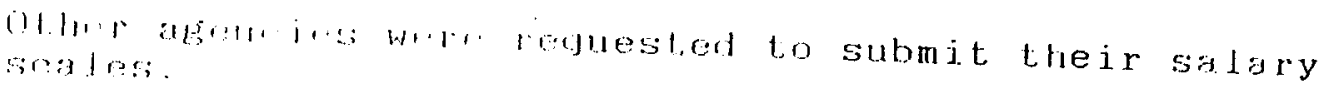

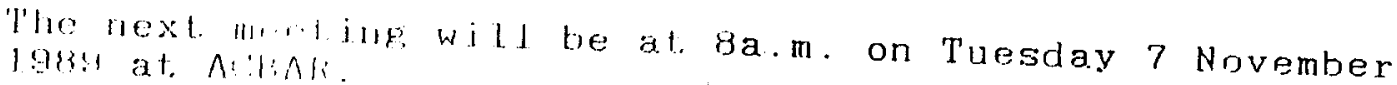
tresent:

\section{1}

A. Baqi Metraban

Dr. J. Baker

IINIII

Arne M. Stieser

INDF

Xavier Bouam

I.F. Rubin

MALIERA

A.R. Ghafoor $i$

Dr. Sayed Mohammad

llartin Valks

Noor Sharif

[1. Masood Kholwaty

HAUERA

Vaif

GAF

IAS:

DS:A

ARC.

Jeff livermar

$m: A$

Avri. $\mathrm{Caleb}$

$\therefore N$

ACHAR 
ACBAR VETERINARY COORD INATION COMMITTEE

MEETING MINUTESS

7 November 1989

\section{ATTENDANCE}

Dr. Bahader

Dr. Sanaul Hacl

ARC: / ASAR

Martin Valks

CAS

DCA

A.R.Ghafoori GAF

Dr:s.Mohammad GAF

Dr.Mehraban UNDP

Wim Bakker World Vision

Eng.Siayed Aga World Vision

Nadette Foley ACBAR

\section{SALARIES FOR FIELD STAFF}

World Vision announced their salary terms, because they had

not been able to attend the last meeting:
Vaccinator 2,500 rup/month

Paravet

2 , soorup/manth

3 , ooorup/month

Medical benefit: Bills will be refunded up to 1,500 rup/year.

World Vision canng reduce salaries of existing staff, but would agree to stafdardise salaries in future if they
expand.

Madera and VSF do not want to increase their salaries.

There was a long discussion on salaries. It was agreed that the length of training, type of work and the actual performance of the individual would all need to be taken into account. There was consensus on a rate of 1,500 rup/month for vaccinators. On the question of regular salary increases, it was agreed that it was desirable, but as a pfuture Afghan government would not be able to match thes'e salaries, NGOs should be realistic in the meantime.

\section{I. CHARGES FOR VETERINARY SERVICES}

The Afghan government never charged farmers for veterinary services. NGOs feel that charging may be necessary in the long rum, but not in the reconstruction stages. It was agreed that NGOs working in the same area must have a common policy on charging, but that there could be legitimate reasolns to have two different policies for two very 


\section{9}

In general Lhe UN does not want charges imposed for goods or services. LINHCR is completely against all charges while UNDP will allow charges if there is proper accounting of all monies collecled. Il was felt that it would be difficulitu control the money collected and there would be an increase " in supervision and monitoring problems.

It was agreed not fo have charges now, but to work out a good system for chprging in the future, and to re-assess the situation after one year. It was felt that the Madera sytem is good, but may not be applicable everywhere.

\section{I : AgENDA TUESDAY 21 NOVEMBER}

The subject will be the relative importance of endemic diseases and control measures which should be implemented. NGOs are requested to prepare and bring along statistics and othent information they have collected on this topic. 


\section{0 \\ ACBAR \\ VETERINARY COORDINATION COMMITTEE \\ 21 November 1989}

\section{Minutes}

Attendance

$\begin{array}{ll}\text { Mark Pont } & \text { Afghanaid } \\ \text { John Tacon } & \text { DAI } \\ \text { Dr A Qadir } & \text { DCA } \\ \text { G J Duives } & \text { DCA } \\ \text { Dr Sayed Mhd } & \text { GAF } \\ \text { Xavier Bouan } & \text { MADERA } \\ \text { Dr Mehraban } & \text { UNDP } \\ \text { Nadette Foley } & \text { ACBAR }\end{array}$

$\begin{array}{ll}\text { Dr. Eahader } & \text { ARS/ASAR } \\ \text { Al Sollod } & \text { DAI } \\ \text { Nartin Valks } & \text { DCA } \\ \text { Brad Miller } & \text { EIL } \\ \text { A R Ghafoori } & \text { GAF } \\ \text { Jeff Liverman } & \text { SNI } \\ \text { J F Rubin } & \text { VSF }\end{array}$

I. Chairman and Future Role of the Committee

There was a discussion about the role and purpose of a veterinary coordination committee within ACBAR. The present committee is mostly composed of the members of the former Veterinary Task Force of the Agriculture Sub Committee, and the initial meeting was organised by UNDP. It was agreed that the committee's role is to recommend policies for and coordinate field work in Afghanistan.

Gerd Jan Duives was proposed and agreed as Chairman.

II. Availability of Suitable Vaccines in Pakistan

There was a long discussion about the current situation, with all vaccines being produced by the Veterinary Research Institutes in Pakistan. There is a state monopoly, with all vaccines either made by. VRIs or imported. The VRI in Quetta has better vaccines and uses better packing materials, but charges higher prices. Some agencies felt that the Lahore VRI gives a better service than the Peshawar VRI. The meeting agreed that Gerd Jan Duives, Sayed Mohammad, Jean Francois Rubin, Xavier Bouan and Dr Qadir would meet Dr Mehraban from UNDP on Wednesday 22 November to set conditions for the technical standards of the required vaccines. Then an approach will be made to the Director of the Peshawar. VRI to ask him if they can provide the vaccines on time to the required standards.

For the future, VSF will establish a vaccine production unit in Gilgit within a year. Dr Solod from DAI explained that they are investigating the opportunities of supporting private agri-business in supplying commodities to the agricultural sector in Afghanistan. They want to develop a sustainable animal health delivery system for Afghanistan which would inlcude provision of veterinary products. 


\section{II . Endemic Diseases in Afghanistan}

\section{1}

The meeting agreed that is is vital to have more information on what endemic diseases exist inside Afghanistan and where they occur. Martin Valks already has a data base on endenric diseases, but the movements of nomadic herds confuse and complicate this information. Liberation of areas from Government control has increased nomadic movement, and with it disease spread.

Both VSF and MADERA distributed disease surveys they have carried out. The last reliable statistics are from 1972 , and there are no systematic epidemiology studies going on now. DCA field officers are collecting data on disease incidence as part of their work.

IV. Vaccination

It was agreed to first vaccinate against the diseases for which vaccines are available in Pakistan. The first priority diseases are:
1. Anthra̧xuN
2. Black ter
3. Entero Toxaemia
4. Newcastle disease
5. Ecto parasites
6. Haemorrhagic Septaecemia

It was agreed that a calendar would be set up to schedule suitable times for vaccination taking account of the different regions.

v. Anthrax Vaccine

There was some pre war vaccination, mainly of sheep when anthrax outbreaks occured. The large nomadic flocks were a huge source of anthrax and it was found in oxen, sheep and humans. The meeting agreed to recommend twice yearly anthrax vaccination except in the north and north central part of Afghanistan, including Badakshan. It was also agreed to vaccinate all sheep, and do cattle if a cattle outbreak has occured in the area. It was noted that about $10 \%$ of cattle, mostly young animals, a much lower percentage than sheep are affected in an anthrax outbreak.

VI. Long Term Plans

John Tacon from DAI expressed the need for farmer education in the long term so they can make the judgement themselves a.s to which vaccines are needed for their own animals. He told of an instance in Badghis where a vaccinator comes from a government held area and is paid by the farmers, but they were unaware which diseases they were protecting against. 


\section{2}

$\frac{\text { GERMAN AFGHANISTAN FOUNDATION }}{\text { Veterinary Project }}$
Dr.DIN MOHAMMAD's Report about RABIES

Dr. Din Moharmad who has worked with GAF since 1986, in Charkh Logar stated the following in his report:

It was in 1985, when I saw first case of RABIES in a person, Shir Mohamnad , who lived in Shash Qullah, Charkh, Logar, who was bitten by a dog while he was building the wall of a garden. lle did not know the dog, was RABIES or not.

After getting first aids he continue his work. Ilis wound was apperently recoverd, but RABIES kept working in his body. At the point, when he got to the last stage of the disease has relatives found out that he was bitten by dog having RABIES, they toke him to Kabul for treatment. But it was very late for him to be held with his illness, at that time I was a student at veterinary faculty of Kabul University, since the patient was my relative, too. I went to visit him at Wasil Abad, where was he kept for the rest of his live.

Then saw him he was in the last stage e.g. excitenent phase of RABIES. Salivation, and coordination of movenent, and agressivity were the signs wihich I saw in the , w whllw, patient: When some body went closer to him, he attacked him, Fainaly he died"
after two days.

In 1983, I saw second casłe of RABIES. When a dog bit two little girls, a little boy, and two elder persons. The dog had RABIES so people killed it and the victims were sent to Kabul for Vaccination, as a result they did not get RABIES.

In 1986, i saw third case of RABIES in Dabbar, Charkh, Logar. When a dog had attacked a flock of sheeps and goats two goats along wi.th flock (Cowboy) were bitten by the dog. While escaping the dog was shot and killed by the Guard, and the bitten goats were immidiatly slaughtered. The gaurd didnot know that the dog had RABIES, but after some times he got illness they got him by a doctor nearby our clinic, so I saw him. The signs were exactly the sane as in the case of Shir Molpanmad. The doctor advised patient relatives to take hin for treatment to Kabul, 'but the patient could not make it and he died on the next day.

I saw in 1988 fourth case of BABIES in Kharwar, Charkh, Logar. When a person $\mathrm{Mr}$. Allam, brought a cow and horse to our clinic, when I asked him about the history of disease he told me that the cow and horse have been sick for two days. The answer to iny second question, whether the cow and horse were sick before,
was, negative.

During physical examination the horse got my attention, it was very exciting unable to swallow feed, incoordination of lambs. Also it tended to bite and swallow thinks around it in the clinic and to roll down on the ground. At the first look I thought of colic. When I imspescted the cow I observed yellowish discharge if tom it's mouth tears flow fröm it eyes discharge form nose and paralaysis of the limb's muscles I thought of stomatitis, when I wanted to exanine its mouth. 


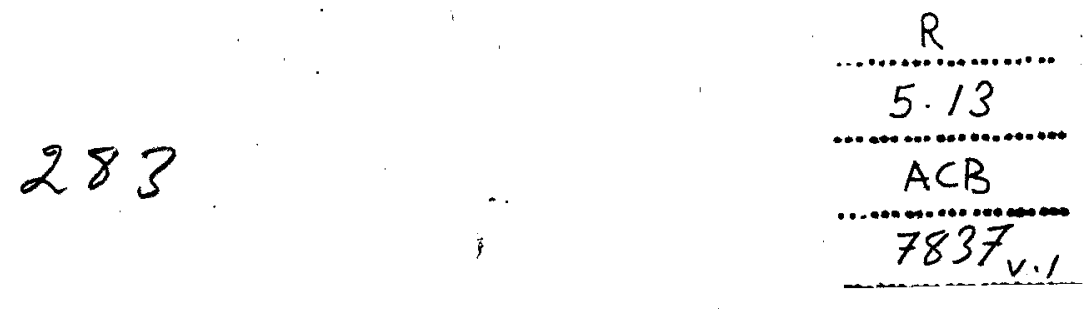

Suddenly the iching wound on the thigh on the cow got my attention after carefuil inspection I asked inspection I asked the owner. What happend to the cow ? He told me the story of his dog which he tought is crazy. Because the dog was chewing it's chain and attacking itself. When I realsed the dog, gettiing out of the house it bit the cow and the horse. When asked him that where is the dog? He replied, I do not kwon what happend to the dog since then. I told him that your cow and hotse were bitten by the dog having RABIES, so they got RABIES, too. Then I give him appropiate instruction. He left back for kharwar, where he 1 ived. On the way he was attacked and bitten by the horse. After: attacking him the horse and cow died on the way. lle returend back and told me the story. I sent him immidiatly to Kabul for vaccination.

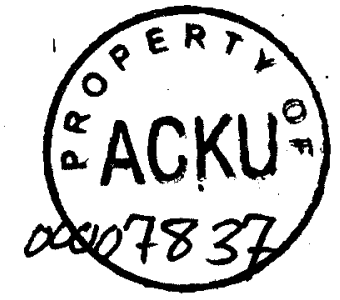

11.1 